São apresentados dados quanto ao curso (perfil dos alunos, desafios da implementação e a atuação dos tutores) e textos abordando as iniciativas de gestao e implementaçao de polticas publicas em municipios gauchos. Estes textos foram selecionados por tratarem e representarem a diversidade de temas que foram objelo de curso. pelos alunos en seus trabahos de concluse

\title{
Gestão Pública Municipal
}


Diogo Joel Demarco

Fabio Bittencourt Meira

Ronaldo Bordin

(ORGANIZADORES)

\section{Gestão Pública Municipal}

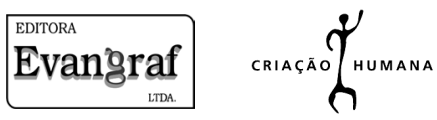

Porto Alegre, 2017 
(C) Copyright: dos autores

Produção Gráfica e Impressão: Evangraf - (51) 3336.2466

\section{CURSO DE ESPECIALIZAÇÃO EM GESTÃO PÚBLICA MUNICIPAL -PNAP/2013-2015}

Coordenador Geral: Diogo Joel Demarco

Coordenadora de Tutoria: Raquel Engelman Machado

\section{EQUIPE ADMINISTRATIVA}

Apoio administrativo-pedagógico: Amanda Carolina Prates da Silva, Ananda Jamile Soares Silva, Anelise Alves Vieira, João Padilha Moreira, Jonathan Carletti Silva, Lara Santos, Louise Ramos da Cunha Freitas, Vanessa Machado de Matos.

\section{EQUIPE PEDAGÓGICA}

Corpo docente (disciplinas): Profs. Drs. Ana Mercedes Sarria Icaza, Aragon Érico Dasso Júnior, Ariston Azevedo Mendes, Clézio Saldanha dos Santos, Cristina Amélia Pereira de Carvalho, Diogo Joel Demarco, Fernando Dias Lopes, Ivan Antônio Pinheiro, Luis Roque Klering, Mariana Baldi, Odair Gonçalves, Rosimeri Carvalho Silva, Rosinha da Silva Machado Carrion, Sueli Maria Goulart da Silva.

Tutores de disciplinas EAD: Alba Conceição Marques dos Santos, Alice Lopes de Oliveira, Carla Garcia Bottega, Daniele dos Santos Fontoura, Eduardo Woltmann, Esther Engelman Machado, Gabriele Gottlieb, Liliane Szczepanski Santana, Luís Fernando Krans, Michelle Nascimento da Silva, Osni Keller Lima, Marina Nunes, Patricia Bianchessi Domingues, Patrícia Tometich, Rafael Engelman Machado. Rosária Lanziotti Moraes, Tulio Pires Watanabe, Vinícius Porto de Ávila.

Tutores presenciais: Carla Patrícia Hennemann, Dieice Fagundes de Oliveira, Marcia Maria Oliveira dos Santos, Mariana dos Reis Pinto, Mariza Kuhn dos Santos, Renata Crislaine Schu de Souza, Vania Patrícia da Silva.

Corpo docente (orientação): Andrea Poleto Oltramari, Aragon Érico Dasso Júnior, Camila Furlan da Costa, Carlos Honorato, Clezio Saldanha dos Santos, Cristina Amélia Carvalho, Eber Pires Marzulo, Eduardo Munhoz Svartman, Everton Farias, Guilherme Ribeiro Macêdo, Ivan Antônio Pinheiro, Marcelo Nogueira Cortimiglia, Mariana Baldi, Máris Caroline Gosmann, Odair Gonçalves, Pedro Almeida Costa, Rafael Kruter Flores, Rosa Angela Chieza, Sueli Maria Goulart Silva, Wendy Beatriz Witt Hahaddad Carraro.

Tutores de orientação a distancia: Alba Conceição Marques dos Santos, Alice Lopes de Oliveira, Amanda Grasiela da Luz Peres, Ana Luísa Poersch, Esther Engelman Machado, Michelle Nascimento da Silva, Patrícia Bianchessi Domingues, Patricia Tometich, Roberta Cristina Sawitzki, Rosária Lanziotti Moraes, Thaís Recoba Campodonico.

\section{Dados Internacionais de Catalogação na Publicação (CIP)}

G393 Gestão pública municipal / Diogo Joel Demarco, Fabio Bittencourt
Meira, Ronaldo Bordin (organizadores). - Porto Alegre :
Evangraf / Criação Humana, 2017.
312 p. : il.
Inclui bibliografia.
ISBN 978-85-88022-67-6
1. Administração pública - Rio Grande do Sul. 2. Administração
municipal - Rio Grande do Sul. I. Demarco, Diogo Joel. II. Meira,
Fabio Bittencourt. III. Bordin, Ronaldo.
$\begin{aligned} & \text { CDU 352(816.5) } \\ & \text { CDD 352.08165 }\end{aligned}$

(Bibliotecária responsável: Sabrina Leal Araujo - CRB 10/1507) 


\section{Apresentação}

No âmbito do sistema da Universidade Aberta do Brasil (UAB) e do Programa Nacional de Formação em Administração Pública (PNAP), a Escola de Administração da Universidade Federal do Rio Grande do Sul (EA/UFRGS) lançou em 2013 a segunda edição dos Cursos de Especialização de Gestão Pública Municipal, Gestão Pública e Gestão em Saúde, modalidade a distância.

O PNAP oferta cursos de graduação e especialização destinados à criação de um perfil nacional do administrador público, propiciando a formação de gestores que utilizem uma linguagem comum e que compreendam as especificidades de cada uma das esferas públicas (municipal, estadual e federal). Os cursos passam a integrar o conjunto de cursos oferecidos pelo Sistema UAB e são ofertados gratuitamente nos polos de apoio presencial da Universidade Aberta do Brasil.

Estes cursos de especialização destinavam-se aos portadores de diploma de curso superior que exercessem atividade em órgãos públicos ou organizações da sociedade civil ou com aspirações ao exercício de função pública. Os cursos pretendem capacitar quadros de gestores para atuar na administração do governo e unidades organizacionais, bem como a de profissionais com formação adequada para intervir na realidade social, política e econômica e, assim, contribuir para a melhoria da gestão das atividades desempenhadas pelo Estado brasileiro, nos âmbitos federal, estadual e municipal (CAPES, 2009).

Especificamente quanto ao Curso de Especialização de Gestão Pública Municipal (GPM), esta edição contemplou 321 inscritos, distribuídos em 8 polos no Rio Grande do Sul (RS), quais sejam: Novo 
Hamburgo, Panambi, Picada Café, Santo Antônio da Patrulha, São Francisco de Paula, São Lourenço do Sul, São Sepé e Três Passos.

Este livro está organizado em três seções. A primeira delas, em dois artigos, apresenta os dados desta edição, enfatizando o perfil dos alunos e desafios da implementação do curso, além de uma reflexão sobre a atuação dos tutores na realização do mesmo. A segunda seção é composta por versões modificadas de oito trabalhos de conclusão que, na forma de artigos, abordam iniciativas de gestão e implementação de políticas públicas em municípios gaúchos. Estes trabalhos foram selecionados por tratarem e representarem a diversidade de temas que foram objeto de análise pelos alunos. Por fim, a terceira seção traz os resumos de todos os 90 trabalhos apresentados pelos concluintes ao Curso de Especialização de Gestão Pública Municipal, organizados por ordem alfabética do autor, possibilitando uma visão geral de toda a produção resultante desta edição. A íntegra destes trabalhos encontra-se disponível no LUME, repositório digital da UFRGS, disponível no endereço http://www.lume.ufrgs.br.

Boa Leitura!

Os organizadores 


\section{Sumário}

\section{SEÇÃO I - Curso de Gestão Pública Municipal: a trajetória da UFRGS}

Curso de Especialização em Gestão Pública Municipal (2013-2015):

perfil dos alunos, abrangência e desafios da implementação do curso

Diogo Joel Demarco

Tutoria: A Experiência da Especialização em Gestão Pública Municipal PNAP 2013

Raquel Engelman; Esther E. Machado

\section{SEÇÃO II - Trabalhos selecionados}

O Controle Interno de Nova Petrópolis: como suas recomendações são utilizadas pela administração municipal Ariane Cristina Berti; Odair Gonçalves; Patrícia Tometich

Os Observatórios de Segurança Pública Municipais como Ferramenta de Gestão - o caso do município de Canoas

Claudete de Souza; Cristina Carvalho; Rosária Lanziotti Moraes.

A arrecadação Tributária do Município de Glorinha/RS de 2001 a 2014: limites e possibilidades

Cristiano Oliveira de Souza; Rosa Angela Chieza 101

O Financiamento da Educação Básica e a Execução da Política Pública de Educação Infantil: o caso do município de Farroupilha/RS Diego Silvestrin; Camila Furlan da Costa; Rosária Lanziotti Moraes

O Alinhamento do Planejamento Governamental (PPA) Federal com o Municipal (PPAS) de alguns municípios do RS Fábio Ricardo Cardoso Magalhães; Wendy Beatriz Witt Haddad Carraro 163 
A Democratização da Comunicação Social no Brasil e a Gestão da Comunicação Pública no Município de Porto Alegre Rita de Cássia da S. Becco; Marcelo Cortimiglia

Os Serviços de Proteção Social do Município de Tramandaí: uma análise a partir das normativas legais

Valdionor Dada dos Santos; Rafael Kruter Flores....

A Importância da Apuração de Custos na Administração Pública Municipal

Vanderlei Rodrigues Schneider; Máris Caroline Gosmann

SEÇÃO III - Resumos dos Trabalhos de Conclusão de Cursos (TCCs) 


\section{Curso de Especialização em Gestão Pública Municipal: a trajetória da UFRGS}

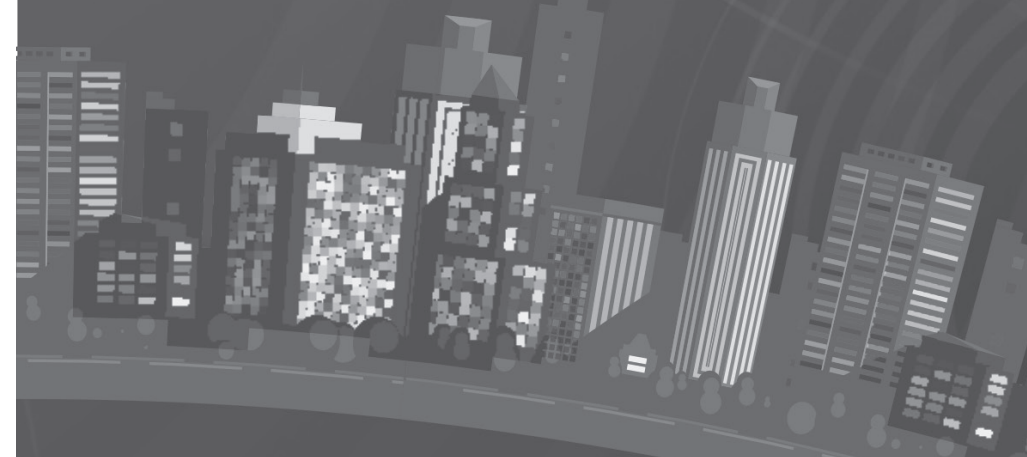




\title{
Curso de Especialização em Gestão Pública Municipal (2013-2015): perfil dos alunos, abrangência e desafios da implementação
}

\author{
Diogo Joel Demarco'
}

\section{Introdução}

Este texto tem por objetivo apresentar um quadro sintético dos grandes números da segunda edição do Curso de Especialização em Gestão Pública Municipal (GPM), ofertado pela Escola de Administração da Universidade Federal do Rio Grande do Sul (EA/UFRGS), no que se refere ao perfil dos alunos e a abrangência do curso, além de um breve balanço dos principais desafios enfrentados na implementação do mesmo. Com isso pretende fornecer ao leitor uma visão ampliada acerca do desenrolar deste programa formativo no decorrer da sua realização.

A EA/UFRGS em parceria com o Sistema Universidade Aberta do Brasil (UAB) do MEC ofertou nesta edição do curso GPM um total de 321 vagas, distribuídas em oito polos no estado do RS, quais sejam: Novo Hamburgo, Panambi, Picada Café, Santo Antônio da Patrulha, São Francisco de Paula, São Lourenço do Sul, São Sepé e Três Passos. A oferta deste quantitativo de vagas e alocação dos polos levou em conta a capacidade de atendimento

Professor da Escola de Administração (EA) da Universidade Federal do Rio Grande do Sul (UFRGS) e Coordenador do Curso de Especialização em GPM. 
da EA/UFRGS bem como a disponibilidade e condições dos polos presenciais².

Este curso de especialização destina-se aos portadores de diploma de curso superior que exercem atividades em órgãos públicos ou em organizações da sociedade civil que tenham aspirações ao exercício de função pública. Para tanto, utiliza ferramentas de educação à distância para qualificar servidores públicos no gerenciamento das máquinas administrativas municipal, estadual e federal. Com isso, o curso busca estar alinhado à realidade existente nestas administrações, objetivando formar egressos aptos a enfrentar dilemas do presente, além de subsidiar os governos e a sociedade para os desafios do futuro.

Esta edição do curso teve início do calendário acadêmico em 05 de outubro de 2013 com uma aula inaugural realizada por meio de conferência on-line e encerramento em 31 de agosto de 2015, após a realização das defesas dos Trabalhos de Conclusão de Curso dos alunos, portanto foram 23 meses de atividades.

\section{Estrutura e funcionamento do Curso}

O curso de GPM é gratuito e realizado na modalidade à distância (EAD), entretanto, as atividades presenciais - ao menos seis encontros presenciais obrigatórios para a realização de atividades de avaliação - aconteceram nos oito polos UAB, credenciados para o curso. despesas referentes à participação nas atividades presenciais foram de responsabilidade dos próprios alunos.

O programa do curso apresentou uma carga horária total de 465 horas, distribuída entre disciplinas organizadas em dois módulos - um básico ${ }^{3}$ e um específico - conforme apresentado no quadro abaixo.

Cabe destacar que no Edital 1 do PNAP, com cursos realizados entre 2010-2012, além da EA/ UFRGS, outras duas IFES ofertaram o curso de GPM no estado do RS. A UFSC ofertou o curso no polo de Seberi e a UFSM ofertou o curso em 4 polos, todos estes polos dos cursos de especialização são diferentes daqueles ofertados pela EA/UFRGS. Os critérios dos editais CAPES não permitem a duplicidade de oferta no mesmo polo.

3 O módulo básico recebe esta denominação pois é comum ao ofertado nos outros dois cursos de especialização no âmbito do PNAP pela EA/UFRGS nesta segunda edição 2013, Curso de Especialização em Gestão Pública (310 vagas ofertadas) e Curso de Especialização em Gestão da Saúde (310 vagas ofertadas), distribuídas em 12 polos presenciais UAB localizados no estado do Rio Grande do Sul. 
Todas as disciplinas foram ministradas por professores da EA e um convidado externo.

\section{Quadro 1 - Programa do curso de GPM, disciplinas, carga horária e docentes.}

\begin{tabular}{|l|c|l|}
\hline \multicolumn{1}{|c|}{ Disciplinas do Módulo Básico } & $\begin{array}{c}\text { Carga } \\
\text { Horária }\end{array}$ & \multicolumn{1}{|c|}{ Docentes } \\
\hline Encontro presencial & & \\
\hline Introdução a Modalidade EaD & $15 \mathrm{~h}$ & Diogo Joel Demarco \\
\hline Estado, Governo e mercado & $30 \mathrm{~h}$ & Ivan Antônio Pinheiro \\
\hline O Público e o Privado na Gestão Pública & $30 \mathrm{~h}$ & Aragon Erico Dasso Júnior \\
\hline Desenvolvimento e mudanças no Estado Brasileiro & $30 \mathrm{~h}$ & Sueli Maria Goulart da Silva \\
\hline Prova Presencial 1 & & \\
\hline Políticas Públicas & $30 \mathrm{~h}$ & Ana Mercedes Sarrialcaza \\
\hline Planejamento Estratégico Governamental & $30 \mathrm{~h}$ & Fernando Dias Lopes \\
\hline O Estado e os Problemas Contemporâneos & $30 \mathrm{~h}$ & Cristina Amélia Carvalho \\
\hline Indicadores Socioeconômicos na Gestão Pública & $30 \mathrm{~h}$ & Rosimeri Carvalho Silva \\
\hline Prova Presencial 2 & & \\
\hline Metodologia Científica & $30 \mathrm{~h}$ & Ariston Azevedo Mendes \\
\hline Disciplinas do Módulo Específico Municipal & Carga & \\
\hline Plano Diretor e Gestão Urbana & $30 \mathrm{~h}$ & Luis Roque Klering \\
\hline Gestão Tributária & $30 \mathrm{~h}$ & Odair Gonçalves \\
\hline Gestão de Redes Públicas e Cooperação & $30 \mathrm{~h}$ & Mariana Baldi \\
\hline Gestão Democrática e Participativa & $30 \mathrm{~h}$ & Aragon Erico Dasso Júnior \\
\hline Prova Presencial 3 & $30 \mathrm{~h}$ & Clezio Saldanha dos Santos \\
\hline Gestão Logística & $30 \mathrm{~h}$ & Rosinha da Silva M.Carrion \\
\hline Elaboração e Avaliação de Projetos & $30 \mathrm{~h}$ & Mariana Baldi \\
\hline Processos Administrativos & & \\
\hline Prova Presencial 4 & & \\
\hline Orientação do TCC & & \\
\hline Bancas de Defesa de TCC & & \\
\hline
\end{tabular}


A carga horária de estudos exigia que o aluno devesse empenhar no mínimo 10 horas de estudo por semana (incluindo participação nas atividades - fórum ou portfólio - e leituras dirigidas) e exigiam presença on-line dos estudantes (por exemplo, chats e webconferências) que ocorriam preferencialmente à noite. A atividade síncrona (chat) era realizada todas as quartas das $19 \mathrm{~h} 30 \mathrm{~min}$ às $20 \mathrm{~h} 45 \mathrm{~min}$.Para participar adequadamente das atividades do curso, o aluno necessitava dispor de computador com acesso à internet banda larga ou se deslocar a um dos polos presenciais, que possuíam equipamentos à disposição.

O material didático com a bibliografia mínima foi disponibilizado gratuitamente aos alunos selecionados sem formato digital, por meio da Plataforma MOODLE Institucional da UFRGS, utilizado como ambiente virtual de aprendizagem (AVA).

Os tutores de apoio foram recrutados por meio de processo seletivo, onde se priorizou, além dos conhecimentos na área temática da disciplina em questão, dando prioridade para mestrandos e doutorandos dos programas de pós-graduação da UFRGS, a experiência de trabalho em EAD. Os tutores passaram por processo de qualificação para uso do ambiente virtual de aprendizagem.

Para a obtenção do título de especialista em gestão pública municipal, o aluno, além de ser aprovado em todas as disciplinas, necessitou apresentar e defender, perante uma banca de dois professores, um Trabalho de Conclusão de Curso (TCC) referente às temáticas trabalhadas ao longo do curso. As bancas de defesa foram realizadas nos oito polos UAB e na sede da EA/UFRGS em Porto Alegre.

\section{Processo e critérios de seleção}

Os interessados no curso realizaram sua inscrição de forma on -line, preenchendo um questionário, no qual, além de informações de formação, perfil, vínculo profissional, entre outras, deveriam realizar a escolha da opção do polo no qual iria realizar as atividades 
presenciais. As inscrições estiveram abertas, por meio de edital de seleção de alunos, no período entre 15 de maio a 07 de junho de 2013.

Os critérios de seleção dos alunos, estabelecidos em consonância com as diretrizes nacionais do PNAP/UAB, são os descritos abaixO:

- Dispersão geográfica entre os municípios do estado do RS - a partir do município de residência, não exclusivamente a cidade do Polo, mas a região do seu entorno;

- Vínculo com o serviço público - prioridade para os servidores públicos;

- Tipo de vínculo com o serviço público (estatutários, CLT, prestadores de serviços, cargos de confiança) - nessa ordem, prioridade decrescente;

- Tempo de serviço - prioridade para funcionários mais recentes.

- Área de atuação - priorizando as áreas de atuação mais afins ao objetivo e área do curso;

- Se já possuía ou não titulação em cursos de pós-graduação prioridade para quem não possuía.

\section{Dados gerais do curso de Gestão Pública Municipal}

Estes critérios foram importantes não apenas em garantir o perfil almejado pelo curso, como também, serem ferramenta eficaz de seleção dada a grande procura e demanda social pelo curso, como se evidenciam os dados do número de candidatos inscritos por polo, apresentados no quadro abaixo. Tais dados demonstram não apenas o grande interesse e procura por vagas, como também a dispersão geográfica dos cursos, atendendo um dos objetivos principais do PNAP que é a oferta de oportunidades de qualificação da gestão pública nos locais de menores possibilidades de acesso às atividades de qualificação. 


\section{Quadro 2 - Vagas, inscritos e formados no curso de Gestão Pública Municipal, por polo.}

\begin{tabular}{l|r|r|r|r|r}
\hline \multicolumn{1}{|c|}{ Polo } & Inscritos & Vagas & $\begin{array}{c}\text { Inscritos/ } \\
\text { Vaga/Polo }\end{array}$ & $\begin{array}{c}\text { Alunos } \\
\text { Formados }\end{array}$ & $\begin{array}{c}\text { Formados } \\
\text { em } \%\end{array}$ \\
\hline Novo Hamburgo & 239 & 50 & 4,8 & 20 & 40,0 \\
\hline Panambi & 42 & 30 & 1,4 & 08 & 26,7 \\
\hline Picada Café & 57 & 51 & 1,1 & 20 & 39,2 \\
\hline Santo Antônio da Patrulha & 144 & 50 & 2,9 & 13 & 26,0 \\
\hline São Francisco de Paula & 105 & 50 & 2,1 & 13 & 26,0 \\
\hline São Lourenço do Sul & 35 & 30 & 1,2 & 08 & 26,7 \\
\hline São Sepé & 35 & 30 & 1,2 & 03 & 10,0 \\
\hline Três Passos & 46 & 30 & 1,5 & 05 & 16,7 \\
\hline Total & $\mathbf{7 0 3}$ & $\mathbf{3 2 1}$ & $\mathbf{2 , 2}$ & $\mathbf{9 0}$ & $\mathbf{2 8 , 0}$ \\
\hline
\end{tabular}

Fonte: Elaboração própria a partir dos relatórios de acompanhamento do PNAP/UFRGS, 2015.

Importante ressaltar que esta alta procura pelo curso se evidenciou nos dois outros cursos do PNAP ofertados concomitantemente pela EA/UFRGS - Gestão Pública (310 vagas) e Gestão em Saúde (310 vagas). Foram ao todo 2.935 inscritos para os três cursos, oriundos de 277 municípios de 16 estados, sendo 230 municípios do RS e os demais 47 municípios de outros 15 estados brasileiros. Destes, 938 foram os selecionados e inscritos nos cursos, oriundos de 196 municípios do país, sendo 191 municípios no RS e quatro de outros estados (SC, RJ, DF e RO) ${ }^{4}$.

No que se refere ao número total de inscritos no curso de GPM observa-se que a procura foi bastante expressiva, com um total de 703 inscritos (uma média de 2,2 candidatos por vaga), com uma elevada procura no polo de Novo Hamburgo, onde esta relação foi de 4,8 candidatos por vaga.

4 Como o foco deste texto é apresentar os dados específicos do curso de Especialização em GPM, para um balanço geral com dados de todo o programa recomenda-se a leitura de artigo de minha autoria "A formação de gestores públicos no Brasil: um balanço das contribuições do Programa Nacional de Formação em Administração Pública (PNAP)", apresentado no VIII Congresso do CONSAD - Brasília, 2015. 
Especificamente no que se refere aos selecionados no curso de GPM foram 321 matriculados, oriundos de 99 municípios, sendo um de SC e 98 do RS (número que representa 19,7\% dos 497 municípios do estado). O gráfico 1 abaixo apresenta a dispersão geográfica dos inscritos nos 20 municípios de maior frequência, que totalizou 208 inscritos (64,8\% do total), sendo que os demais 113 inscritos (35,2\%) foram oriundos de 79 municípios, numa média de 1,4 inscrito por município.

\section{Gráfico 1 - Dispersão geográfica dos inscritos no GPM nos 20 municípios de maior frequência.}

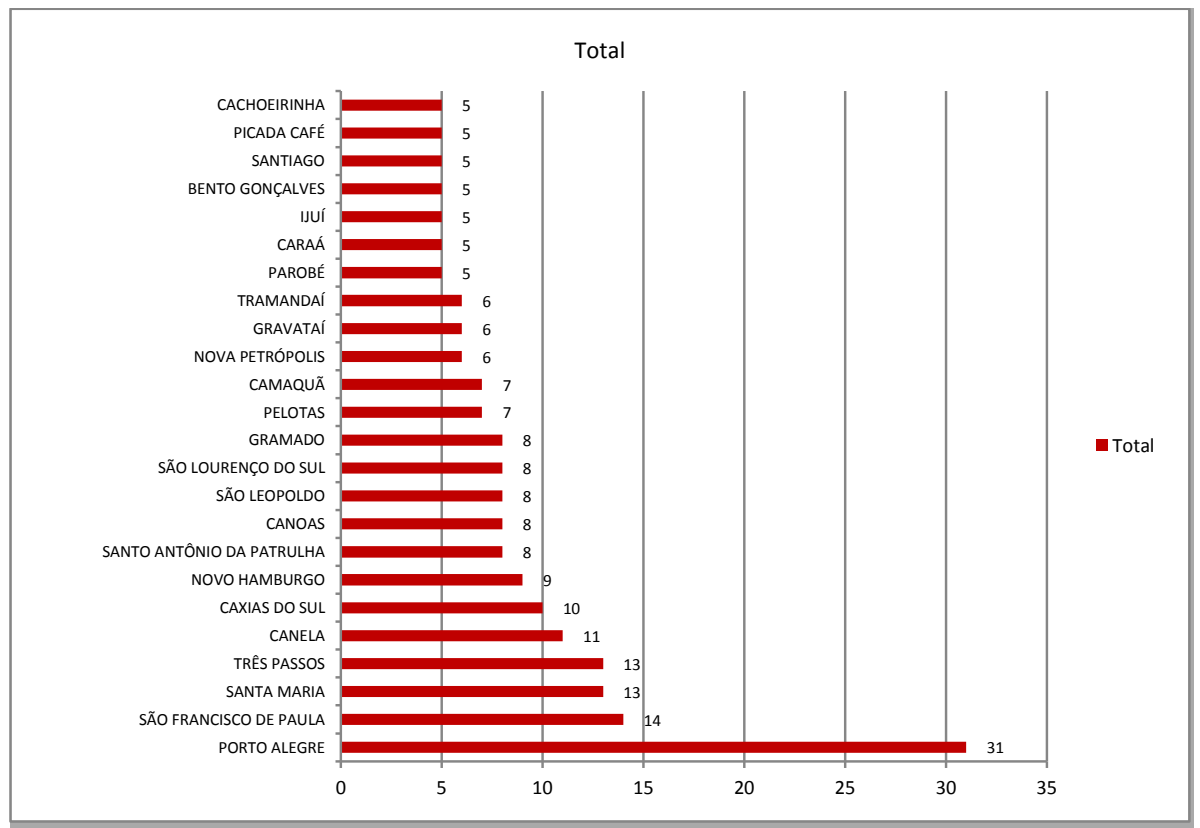

Não obstante a grande procura e seleção de alunos localizados no município de Porto Alegre (31 selecionados, representando 9,6\% do total) que, apesar de sede da EA/UFRGS não ser a época um dos polos presenciais do Sistema UAB, os dados demográficos apresentados acima explicitam o caráter democrático do programa em termos de acesso ao ensino de pós-graduação, em nível de especialização, a 
um público distante de grandes centros ou que, mesmo em centros maiores, não tem condições de frequentar cursos regulares presenciais em função dos vínculos de trabalho e do custo dos mesmos. Ao contemplar as mais diferentes regiões do estado do RS o programa possibilita condições de desenvolvimento dos municípios pela capacitação gerencial para atuação na administração pública nos diferentes níveis, especialmente no nível local.

Quando se analisa esta dispersão geográfica entre os 90 concluintes do curso de GPM observa-se que os mesmos são oriundos de 45 municípios do estado do RS (ou seja, 9\% dos 497 municípios gaúchos). Destaca-se, em termos de alunos formados os municípios de Porto Alegre (15), Novo Hamburgo (07), São Francisco de Paula (06), Caxias do Sul e Três Passos (04), ljuí e Canela (03).

\section{Perfil dos alunos}

Em relação ao perfil dos alunos selecionados e aprovados no curso GPM importa destacar alguns aspectos relacionados à composição demográfica e ao vínculo institucional e profissional com o setor público nos municípios do estado.

Entre os alunos selecionados, em relação à distribuição por sexo, verifica-se uma predominância das mulheres, com 176 matriculadas do sexo feminino (54,8\%) e 145 (45,2\%) matriculas do sexo masculino. Esta proporção é muito próxima da distribuição por gênero do número total de inscritos no curso (703), onde 402 eram do sexo feminino $(57,2 \%)$ e 301 dos inscritos eram do sexo masculino $(42,8 \%)$.

No que tange aos 90 concluintes do curso, observa-se que 48 são do sexo feminino (53,3\%) e 42 são do sexo masculino $(46,6 \%)$.

No tocante à faixa etária dos alunos selecionados observa-se, conforme apresentado na tabela abaixo, uma prevalência dos mais jovens na busca por qualificação. Do ponto de vista de idade média nas diferentes faixas etárias observa-se que $63,7 \%$ dos alunos tinham até 40 anos, ou seja, ainda possuem um período significativo de ativi- 
dade no setor público e, portanto, um período maior para aplicação e utilização dos conhecimentos de gestão apreendidos no curso. Tal aspecto se ressalta ainda mais se observarmos que na faixa etária entre 21 a 30 anos estavam 27,4\% dos selecionados.

Já no que se refere a faixa etária dos alunos concluintes do curso destaca-se o percentual elevado entre os alunos nas faixas entre 31 a 40 e 41 a 50 anos que, juntas representaram 64,4\% dos aprovados no curso, evidenciando uma maior envolvimento e possivelmente maior dedicação para a conclusão do mesmo.

Tabela 1 -Matriculados e aprovados no GPM, por faixa etária.

\begin{tabular}{|l|r|r|r|c|}
\hline & \multicolumn{2}{|c|}{ Matriculados } & \multicolumn{2}{c|}{ Aprovados } \\
\hline \multicolumn{1}{|c|}{ Faixa etária } & Número & $\%$ & Número & $\%$ \\
\hline $21 / 25$ anos & 29 & 9,0 & 10 & 11,1 \\
\hline $26 / 30$ anos & 59 & 18,4 & 16 & 17,8 \\
\hline $31 / 40$ anos & 128 & 39,9 & 29 & 32,2 \\
\hline $41 / 50$ anos & 84 & 26,2 & 29 & 32,2 \\
\hline $51 / 60$ anos & 20 & 6,2 & 6 & 6,7 \\
\hline Não informou & 1 & 0,3 & - & - \\
\hline Total & $\mathbf{3 2 1}$ & $\mathbf{1 0 0 , 0}$ & $\mathbf{9 0}$ & $\mathbf{1 0 0 , 0}$ \\
\hline
\end{tabular}

Fonte: Elaboração própria a partir dos relatórios de acompanhamento do PNAP/UFRGS, 2015.

Do ponto de vista do vínculo institucional dos alunos selecionados observa-se uma maioria com vinculação ao serviço público, 302 matriculados (94,1\% do total), refletindo claramente os critérios de prioridade aos alunos com vínculo profissional com o setor público. Destes 270 tinham atuação no nível municipal, 23 no nível estadual e outros 09 atuavam no nível federal. Do total de 302 matriculados com vínculo com o setor público, 245 eram dos governos municipais (prefeituras), 22 eram dos legislativos municipais (Câmaras de Vereadores), 16 alunos eram do governo estadual, 05 eram oriundos de empresas públicas, 04 oriundos do poder judiciário federal; de fundações públicas, universidades federais e órgãos do governo fe- 
deral vinham 02 representantes cada; além de um aluno da justiça e um de consórcio intermunicipal. Em termos do vínculo profissional predominavam os estatutários (234), os cargos em comissão (33), os celetistas (15) e cargos eletivos - prefeitos e vereadores (9).

Quando analisamos o vínculo institucional dos concluintes do curso observa-se que 85 deles possuíam vínculo com a administração pública e 05 não possuíam este vínculo. Dos que possuíam vínculo com a administração pública 74 era com atuação no nível municipal, sendo 64 com a prefeitura municipal, 09 com o legislativo municipal e $01 \mathrm{~cm}$ consórcio intermunicipal. Outros 09 tinham atuação no nível estadual, sendo 05 no governo estadual, 02 em empresas públicas e 01 do judiciário e fundação pública, respectivamente. Dois atuavam no nível federal, sendo um do judiciário e outro de universidade federal.

No que se refere ao tipo de vínculo profissional dos concluintes predominavam os estatutários (67), os cargos em comissão (07), os celetistas (07) e cargos eletivos (02 vereadores).

\section{Desafios na implementação do curso}

Dentre os diversos desafios à implementação de um curso como o GPM, na modalidade EaD, com um número grande de alunos, dispersos em oito polos espalhados pelo estado do RS, com as dificuldades de regularidade no financiamento, sobretudo na concessão de bolsas para docentes e tutores, certamente a evasão dos alunos é o principal deles. Dos 321 alunos inscritos no início do curso apenas 90 deles (28\%) concluíram o curso com a certificação de especialistas em gestão pública municipal, evidenciando um baixo grau de aprovação.

A tabela abaixo apresenta o número de alunos em cada fase do curso, onde é possível se identificar os momentos de maior saída de alunos no decorrer do curso. Cabe salientar que pelo fato da avaliação das disciplinas ser distribuída entre atividades EaD (50\%) e avaliação presencial (50\%), é após a consolidação das avaliações 
presencias, realizadas a cada bloco de três ou quatro disciplinas, que se pode realizar este acompanhamento efetivo do desempenho dos alunos.

\section{Tabela 2 - Alunos matriculados e aprovados no GPM, por etapa do curso.}

\begin{tabular}{|l|c|c|c|c|}
\hline $\begin{array}{l}\text { Etapas do Curso GP } \\
\text { Municipal }\end{array}$ & $\begin{array}{c}\text { Matriculados } \\
\text { por Etapa }\end{array}$ & $\begin{array}{c}\text { Número de } \\
\text { Evadidos por } \\
\text { Etapa }\end{array}$ & $\begin{array}{c}\% \text { Evasão } \\
\text { na Etapa }\end{array}$ & $\begin{array}{c}\% \text { Concluintes } \\
\text { sobre inicial }\end{array}$ \\
\hline Matriculados iniciais & 321 & & & \\
\hline Prova 1 & 174 & 147 & $-45,8$ & 54,2 \\
\hline Prova 2 & 147 & 27 & $-15,5$ & 45,8 \\
\hline Prova 3 & 137 & 10 & $-6,8$ & 42,7 \\
\hline Prova 4 & 130 & 7 & $-5,1$ & 40,5 \\
\hline Orientação & 129 & 1 & $-0,8$ & 40,2 \\
\hline $\begin{array}{l}\text { Realizaram Defesa do } \\
\text { TCC }\end{array}$ & 93 & 36 & $-27,9$ & 29,0 \\
\hline $\begin{array}{l}\text { Aprovados (Certifica- } \\
\text { dos) }\end{array}$ & 90 & 3 & $-3,2$ & 28,0 \\
\hline
\end{tabular}

Fonte: Elaboração própria a partir dos relatórios de acompanhamento do PNAP/UFRGS, 2015.

A baixa aprovação no curso pode ser creditada a vários fatores, mas, sem dúvidas, a evasão é o principal problema evidenciado, sobretudo no primeiro bloco de disciplinas, onde mais de $45 \%$ dos alunos já não mais estavam no curso. O segundo grande momento de perda de alunos ocorre na etapa de orientação para elaboração do Trabalho de Conclusão de Curso. Este momento em que o aluno, apesar do apoio de orientação, sente-se mais desafiado a transformar uma ideia, uma inquietação, em um estudo estruturado, com desenvolvimento de pesquisa empírica, o que levou um número significativo (36 alunos) a não concluírem a elaboração do TCC.

A evasão é um problema existente em qualquer curso, seja na modalidade EAD ou presencial. Contudo, na EAD, a evasão costuma ser bem maior devido as próprias características do público que 
procura essa modalidade de ensino, a falta de vínculos afetivos mais intensos com a turma e, também, em virtude da pressão do grupo e de outros mecanismos de interação social que o contato físico geralmente proporciona, além das dificuldades geradas pela mediação tecnológica, exigindo grande capacidade de organização e autonomia para auto estudo dos alunos que, precisam conciliar as atividades acadêmicas com suas atividades profissionais.

Ou seja, são múltiplas as causas da evasão e da baixa participação, sendo necessário, nas edições futuras, identificar e atacar as causas da evasão dos alunos visando garantir um baixo percentual de evasão dos mesmos, através de um processo de monitoramento e acompanhamento dos alunos, por meio do ambiente virtual e dos tutores a distancia, bem como, garantir a orientação aos alunos para elaboração do trabalho de conclusão, por se tratar de um momento em que um número expressivo de alunos evade dos cursos por se tratar de uma etapa que exige muita disciplina e dedicação dos mesmos.

Em que pese estas dificuldades, os dados finais de aprovados e a pesquisa realizada com os mesmos ao final, conclui-se que a avaliação do curso é positiva. Ao contemplar as mais diferentes regiões do estado do RS, o curso propicia o fortalecimento e ampliação de capacidades de gestão das administrações locais, contribuindo nas potencialidades de desenvolvimento dos municípios e, sobretudo, contribuindo na oferta de mais e melhores serviços públicos às populações destes municípios.

\section{Referências}

BELLONI, Maria Luiza. Educação a distância. 3. ed. Campinas: Autores Associados, 2003.

DEMARCO, Diogo Joel; ANTUNES, Elaine di Diego; BRUNETTA, Nádia; PINHEIRO, Ivan Antonio. Aspectos do processo de construção do trabalho de conclusão de curso na modalidade a distância: perspectivas dos alunos, tutores e professores orientadores. RENOTE - Revista Novas Tecnologias na Educação, Porto Alegre, vol. 10, n. 3, p. 1-11, dez. 2012. 
DEMARCO, D. J.; DONAZAR, R. C.; BARRETO, R. A. C. M. Políticas de capacitação e desenvolvimento de servidores: o caso da UFRGS. In: Calvete, Cássio da S.; Gosmann, Máris C.. (Org.). Políticas de emprego, trabalho e previdência. $1^{\mathfrak{a} e}$ ed. Porto Alegre: Editora da UFRGS, 2014, v. 1, p. 72-93.

DEMARCO, D. J. A formação de gestores públicos no Brasil: um balanço das contribuições do Programa Nacional de Formação em Administração Pública (PNAP). VIII Congresso CONSAD de Gestão Pública - Brasília, maio de 2015. 29p.

ENAP. Educação a distância em organizações públicas; mesa-redonda de pesquisa-ação. Brasília: ENAP, 2006. 200 p.

GAETANI, Francisco. Capacitação de recursos humanos no serviço público: problemas e impasses. Brasília: ENAP, 1998. 27 f.

GOULART, Deise Mazzarella. Adesão ao Sistema Universidade Aberta do Brasil (UAB): implicações organizacionais na Universidade Federal do Rio Grande do Sul (UFRGS). Dissertação (Mestrado em Administração). Programa de Pós-Graduação em Administração. Universidade Federal do Rio Grande do Sul. Porto Alegre: UFRGS, 2014. 164p.

LITTO, Fredic Michael; FORMIGA, Manuel Marcos Maciel (Orgs). Educação a distância: o estado da arte. São Paulo: Pearson Education do Brasil, 2009.

MOORE, Michael G; ANDERSON, William G. Handbook of Distance Education. New Jersey: Lawrence Erlbaum Associates, Publishers Mahwah, 2003. 


\title{
Tutoria: a experiência da Especialização em Gestão Pública Municipal - PNAP 2013
}

\author{
Raquel Engelman ${ }^{1}$ \\ Esther E. Machado²
}

\section{Introdução}

Apesar de o conceito de tutoria ser muito mais antigo do que a criação dos primeiros cursos a distância, tendo sido institucionalizado nas universidades no século XIX, a discussão do papel do tutor ainda é relativamente recente. Para ilustrar empiricamente a prática da tutoria, identificando suas principais competências e atribuições, bem como os pontos positivos e dificuldades, este capítulo descreve a experiência da Equipe de Tutoria da 2ª Edição da Especialização em Gestão Pública Municipal pertencente ao Programa Nacional de Formação em Administração Pública (PNAP), oferecido na Universidade Federal do Rio Grande do Sul pela Escola de Administração em parceria com o Sistema Universidade Aberta do Brasil (UAB) do Ministério da Educação.

Para tanto, inicialmente é apresentada uma breve contextualização sobre o papel da tutoria no ensino a distância, destacando-se as

1 Doutora e Mestre em Administração pela UFRGS; Graduada em Comunicação Social pela PUCRS. Atua desde 2009 no ensino a distância como professora conteudista, coordenadora de tutoria e tutora na UFRGS e FEEVALE.

2 Especialista em Mídias na Educação (UFRGS), com Aperfeiçoamento em Informática Educativa e cursos na sua área de formação, em EAD, tutoria e TICS. Graduada em História natural, professora estadual aposentada e atualmente professora municipal e conselheira municipal do CACS - FUNDEB e do Conselho de Alimentação Escolar (CAE), em Capão da Canoas-RS. Exerce função de tutoria na UFRGS desde 2011. 
atribuições e competências desejáveis ao tutor, utilizados como base para definir a atuação da tutoria do curso, o conteúdo das capacitações e como seria feito o acompanhamento. A seguir, é apresentada a descrição da experiência do curso, propriamente. Salienta-se, entretanto, que este texto não tem a pretensão de aprofundar as discussões abordadas na literatura, mas oferecer um relato sobre a experiência de tutoria e, quem sabe, suscitar algumas questões para debates futuros.

\section{Bases para definições sobre a tutoria dos cursos PNAP 2013}

Com a criação da Universidade Aberta do Brasil (UAB), se estabeleceu um novo modelo de suporte aos estudantes, por meio da definição inicial dos papéis dos tutores presenciais (nos polos regionais) e a distância (nas universidades, interagindo via internet com os estudantes). Especificamente na Universidade Federal do Rio Grande do Sul (UFRGS), as práticas com a presença de tutores são relativamente recentes e iniciaram após a LDBEN 9394-96. Nesse contexto, a UFRGS, por intermédio da Secretaria de Educação a Distância (SEAD), participou ativamente de editais do Pró-Licenciatura com os Cursos de Pedagogia e de Música, iniciados em 2006 e 2008, respectivamente. Em 2006, também iniciou o projeto-piloto do Curso de Administração, o qual já estava em andamento quando se consolidou o sistema UAB, e, no ano seguinte, começou o Curso de Planejamento e Gestão em Desenvolvimento Rural (PLAGEDER), tornando-se o primeiro curso tecnológico do sistema UAB na UFRGS (CARNEIRO; TURCHIELO, 2013). Além do Curso de Administração, a Escola de Administração da UFRGS, conta com a experiência em diversos cursos, marcadamente Curso de Especialização em Negociação Coletiva iniciado em 2009 em parceria com o Ministério do Planejamento, Orçamento e Gestão; e cursos do Programa Nacional de Formação em Administração Pública (PNAP) iniciados em 2010 e 2013, como Gestão Pública, Gestão Pública Municipal e Gestão em Saúde, entre outros cursos de menor expressão. 
A função de tutoria é anterior à criação dos cursos a distância, mas o papel do tutor na EAD, tal como a conhecemos hoje, teve seu marco histórico ligado à Open University do Reino Unido, no final da década de 60. Naquela época, a prática da tutoria estava organizada sobre um modelo no qual os tutores integravam as ações docentes no curso, buscando orientar e facilitar a aprendizagem dos alunos. Para as autoras, as mudanças tecnológicas que permitiram a criação dos ambientes virtuais de aprendizagem e que possibilitaram o suporte dos cursos a distância via internet, ampliaram as demandas da tutoria, exigindo maior preparo e, consequentemente, maior formação específica do tutor para realizar suas atividades com qualidade (CARNEIRO; TURCHIELO, 2013).

Em 1993, Maya elaborou um dos primeiros guias com orientações básicas sobre a função tutorial, no qual descreve o tutor como um "orientador, um apoio ou facilitador das aprendizagens dos alunos", exercendo um papel fundamental como o mediador do processo de ensino e aprendizagem. Mesmo naquela época, o autor já destacava que o tutor deveria ter "habilidades e conhecimentos muito especiais no manejo das diferentes formas de comunicação utilizadas na modalidade a distância", sendo importante que o tutor "já tivesse alguma experiência em estudar a distância", para que pudesse compreender melhor o seu papel (MAYA, 1993, p. 33).

Segundo Schröeder (2006), as principais atribuições definidas para os tutores do Curso de Administração da UFRGS foram: (a) esclarecer dúvidas dos alunos quanto ao uso da Plataforma e das ferramentas de softwares utilizadas no curso; (b) incentivar e favorecer a diversidade cultural do grupo, facilitando a troca de experiências e conhecimento do conteúdo estudado; (c) comentar e aprofundar as ideias trazidas nos fóruns, relacionando-as aos conteúdos propostos; (d) ser facilitador e incentivador da aprendizagem do grupo de alunos; (e) valorizar a participação individual, promovendo a interação e a cooperação entre os alunos, mantendo o foco nos objetivos do curso; ( $f$ ) distribuir papéis e responsabilidades, orientando as equipes; (g) fornecer rapidamente feedback individual e para o grupo sobre tarefas e discussões; 
(h) responsabilizar-se pela facilitação do cumprimento do programa estabelecido, fazendo-se respeitar o agendamento das atividades propostas; (i) encaminhar os problemas às Coordenações, de acordo com as especificidades; (j) acompanhar a realização dos trabalhos e provas, e corrigir e lançar, no campo apropriado do sistema, os resultados obtidos pelos alunos, se assim definido pelo professor; ( $k$ ) informar ao professor responsável pelo Módulo sobre os eventuais problemas na turma, tão logo ocorram; (I) participar das reuniões com as Coordenações, quando convocados; $(m)$ encaminhar em período estipulado à coordenação pedagógica relatório contendo as perguntas mais frequentes no período, as respostas a tais perguntas e o levantamento quantitativo de dúvidas encaminhadas, indicando os assuntos ou itens do conteúdo a que se referem; ( $n$ ) analisar constantemente o material apresentado aos alunos para verificação de sua exatidão e adequação à proposta da disciplina.

Diversos outros autores organizaram e classificaram as ações esperadas de um tutor, conforme consta no quadro abaixo, resumindo suas principais atribuições:

\section{Quadro 1- Principais atribuições do tutor}

\begin{tabular}{|c|c|}
\hline Categoria & Atribuições do Tutor \\
\hline $\begin{array}{l}\text { Pedagógi- } \\
\text { co, } \\
\text { Orientador } \\
\text { ou } \\
\text { Acadêmi- } \\
\quad \text { co }\end{array}$ & $\begin{array}{l}\text { Atuar como facilitador no processo educacional; planejar atividades e criar ma- } \\
\text { terial didático para uso online; auxiliar os alunos a compreender o conteúdo e } \\
\text { a entender a respectiva relação com os objetivos da aprendizagem; dominar } \\
\text { os conteúdos, realizar a avaliação diagnóstica e formativa, possuir habilidades } \\
\text { didáticas à organização de atividades; dominar o conteúdo e os princípios } \\
\text { filosóficos e éticos da educação, elaborar atividades, avaliar, organizar traba- } \\
\text { Ihos em grupo, responder às duvidas etc.; auxiliar os alunos na realização das } \\
\text { tarefas e nos estudos e os orientar nos processos de aprendizagem; orientar os } \\
\text { alunos, moderar as discussões e; avaliar o processo do aluno no curso. }\end{array}$ \\
\hline $\begin{array}{l}\text { Social ou } \\
\text { comunica- } \\
\text { cional }\end{array}$ & $\begin{array}{l}\text { Auxiliar os alunos a trabalhar juntos; proporcionar a construção de redes de } \\
\text { comunicação e de interação com os atores do curso; envolver os estudantes } \\
\text { nas atividades do curso, estimular a participação dos estudantes, organizar } \\
\text { grupos de estudo, moderar discussões, etc.; apoiar a aprendizagem colabora- } \\
\text { tiva e a formação de comunidades de aprendizagem, motivar a participação } \\
\text { dos alunos; dinamizar e incentivar a ação formativa e o trabalho em rede e; } \\
\text { criar um ambiente no qual os alunos percebam que a aprendizagem é possível. }\end{array}$ \\
\hline
\end{tabular}




\begin{tabular}{|c|c|}
\hline $\begin{array}{l}\text { Organiza- } \\
\text { cional, } \\
\text { Gerencial } \\
\text { ou } \\
\text { Adminis- } \\
\text { trativa }\end{array}$ & $\begin{array}{l}\text { Apoiar os alunos nos aspectos institucionais e administrativos; organizar } \\
\text { as atividades dos alunos pelas quais é responsável; apropriar-se da pro- } \\
\text { posta pedagógica do curso e auxiliar na sua implementação, acompanhar } \\
\text { os alunos na entre dos trabalhos e auxiliá-los na organização do tempo; } \\
\text { estabelecer o calendário do curso, explicar as formas de funcionamento } \\
\text { do ambiente virtual, manter contato com a equipe docente e organizacio- } \\
\text { nal, oferecer informações significativas em relação à instituição organizar } \\
\text { o tempo, coordenar os grupos de estudo, registrar as informações em } \\
\text { relação aos trabalhos realizados, estabelecer contato com os membros da } \\
\text { instituição; encaminhar as questões administrativas e as relacionadas à ins- } \\
\text { tituição e ao projeto pedagógico; e, estabelecer um projeto instrucional } \\
\text { adequado. }\end{array}$ \\
\hline Técnica & $\begin{array}{l}\text { Facilitar o acesso aos recursos tecnológicos; saber usar os diferentes softwa- } \\
\text { res para realizar as atividades de tutoria de forma eficiente; garantir que os } \\
\text { estudantes sejam capazes de possuir certo domínio das ferramentas dispo- } \\
\text { níveis no ambiente virtual de aprendizagem; conhecer e manejar as ferra- } \\
\text { mentas tecnológicas e instruir os alunos sobre a aprendizagem via internet, } \\
\text { auxiliando-os a reconhecer recursos oferecidos pela rede de comunicações; } \\
\text { auxiliar os alunos a se apropriarem dos recursos tecnológicos e de seu uso } \\
\text { no curso e; auxiliar os alunos a se sentirem confortáveis com os recursos } \\
\text { técnicos. }\end{array}$ \\
\hline
\end{tabular}

Fonte: Carneiro e Turchielo (2013, p. 43)

Em relação às principais competências da tutoria, Schröeder (2006) define: domínio satisfatório do conteúdo, das ferramentas/recursos de aprendizagem e da proposta do curso/disciplina; clareza e polidez na colocação das ideias; certa objetividade, sem ser "superficial" ou "evasivo"; proatividade e preparo para imprevistos - planejamento do tempo; agilidade mental e motora no uso da tecnologia de ensino-aprendizagem; foco e atenção; pontualidade; responsabilidade; dedicação; disponibilidade; acessível e flexível; postura gregária; ser um facilitador e não como detentor do conhecimento; postura crítica; motivação, instigação, "provocação"; orientação; habilidade de mediação.

Schneider et al. (2013, p.63-64), com base em suas experiências e em outros pesquisadores, identificaram um grupo das dez competências fundamentais para o tutor $U A B$, relacionadas a seguir: 
Fluência digital: apropriação da informação digital e do potencial de conhecimento gerado (BARRETO, 2009), possibilitando não só o uso, mas também a criação e a produção de conteúdos e materiais através das tecnologias.

Relacionamento interpessoal: competência fundamental na empatia, na mediação pedagógica, na facilitação nos processos de ensino e de aprendizagem, na cooperação, na transferência, no foco ao ser humano, na disponibilidade para trabalhar em equipe, além de fundamentar-se no adequado relacionamento com os alunos, com a coordenação e a equipe do curso.

Organização: competência focada na capacidade de estabelecer contato permanente com os alunos e mediar as atividades discentes. A organização também será essencial à elaboração de relatórios mensais de acompanhamento dos alunos e ao encaminhamento desse material periodicamente à Coordenação de Tutoria.

Planejamento: competência fundamentada no planejamento das atividades de tutoria e na seleção de estratégias adequadas ao grupo.

Disponibilidade para mudança: competência focada na capacidade de adaptação ao estilo de aprendizagem do grupo e ao estilo do professor. Também deve ser considerada a possibilidade de mudança, a partir do feedback dos docentes e dos discentes, além da disponibilidade para participação ativa nas capacitações propostas ao tutor.

Administração do tempo: capacidade de organizar sua agenda de compromissos, a fim de manter regularidade de acesso ao AVA e dar retorno às solicitações do cursista dentro do prazo estabelecido (24 horas).

Motivação do outro e de si próprio: capacidade de manter a motivação no acompanhamento dos alunos durante o desenvolvimento, a orientação e a realização das atividades, sendo um facilitador dos processos. Da mesma forma, o tutor deve ser capaz de acolher as dificuldades dos alunos e de incentiva -los a permanecer no curso, sendo ativo na realização das atividades e na participação através das Tecnologias se Informação e Comunicação (TIC). 
Comunicação: competência fundamentada na clareza e na objetividade da expressão escrita, tendo em vista a função de mediar a comunicação de conteúdos entre o professor e os cursistas. Organização do pensamento, coerência, fluência verbal, além da capacidade de fornecer e receber feedbacks, são competências comunicativas importantes para quem executa a atividade de tutoria.

Reflexão: competência baseada na capacidade de abstração para refletir e analisar criticamente as competências que precisam ser desenvolvidas pelo tutor. Além da atuação como tutor, esse deve responsabilizar-se pelas próprias consequências de suas atitudes.

Posteriormente Behar, Schneider e Silva (2013 apud Schneider et al. 2013) identificaram outras competências como trabalho em equipe, mediação pedagógica e autonomia, entre outras.

Com base no exposto nesta seção, foram traçadas as diretrizes para a condução da Equipe de Tutoria da 2ª Edição da Especialização em Gestão Pública Municipal, esplanada a seguir.

\section{Tutoria no Curso Gestão Pública Municipal - PNAP 2013}

Os tutores presenciais e a distância do curso de Especialização em Gestão Pública Municipal - 2ª Edição - foram selecionados por edital público, publicado no mês de junho de 2013. O edital estava embasado nas diretrizes do Fundo Nacional de Desenvolvimento da Educação do governo federal, que, com a Resolução/CD/FNDE no 8 de 30 de abril de 2010, detalhou as exigências de formação e atuação para tutoria, no qual considera-se que Tutor «é o profissional selecionado pelas Instituições Públicas de Ensino Superior (IPES) vinculadas ao Sistema UAB para o exercício das atividades típicas de tutoria, sendo exigida formação de nível superior e experiência mínima de 1 (um) ano no magistério do ensino básico ou superior, ou ter formação pós-graduada, ou estar vinculado a programa de pósgraduação». De acordo com essa Resolução, o tutor deve: 
1. Ser portador de diploma de graduação compatível com a área de atuação no curso, dependendo das características e das demandas de cada disciplina e enquadrar-se em, pelo menos, uma das situações abaixo discriminadas:

a) formação de nível superior e experiência mínima de 1 (um) ano no magistério do ensino básico ou superior;

b) possuir formação pós-graduada em área compatível com a área de atuação no curso (de acordo com as características e demandas de cada disciplina);

c) estar vinculado a programa de pós-graduação em área compatível com a área de atuação no curso (de acordo com as características e demandas de cada disciplina).

Os que atenderam às condições exigidas no edital e foram selecionados receberam capacitação antes de iniciarem a desenvolver suas atividades. Foram selecionados tutores presenciais para atuar em todos os 08 polos do curso, compartilhados com os outros dois cursos do programa PNAP e 12 tutores a distância, um para cada turma. Os polos em que atuaram foram: Novo Hamburgo (2 turmas); Panambi; Picada Café (2 turmas); Santo Antonio da Patrulha (2 turmas); São Francisco de Paula (2 turmas); São Lourenço do Sul; São Sepé; Três Passos. Cada turma contava em média com 30 alunos, formando um total de 330.

Os tutores atuaram de outubro de 2013 a junho de 2015, visto que o curso optou por trabalhar com uma equipe de tutores permanente. Entretanto, devido ao número de alunos e, consequentemente turmas, o número de tutores foi reduzido no segundo módulo. Além disso, o período de orientação dos Trabalhos de Conclusão de Curso contou com seleção e alocação específicas, devido à quantidade de orientandos e variedade de temáticas. O curso optou por tutores presenciais permanentes nos polos e por um grupo de tutores a distância também permanente no curso, mas que alternavam entre as diversas turmas. Desta forma, a intenção era manter um grupo com maior capacitação e experiência, ao mesmo tempo em que evitava a endogenia. 
A forma de trabalho da Equipe de Tutoria seguiu as diretrizes da UAB, os referenciais apresentados no capítulo anterior e a experiência adquirida na 1a Edição da Especialização em Gestão Pública Municipal, realizada em 2010. Tanto a Coordenação de Tutoria como grande parte da equipe já haviam trabalhado na edição anterior e em outros cursos a distância da Escola de Administração da UFRGS.

Com base nas definições de curso e da forma de trabalho da tutoria, foi elaborada e ministrada, pela Coordenadora de Tutoria no documento Guia do Tutor - Cursos PNAP 2013 (ENGELMAN, 2013), a capacitação e orientação dos tutores presenciais e a distância. A capacitação foi, realizada a distância, já fazendo uso do ambiente virtual de atividade (AVA) do curso, o MOODLE. A capacitação e posterior atuação dos tutores foram pautadas no "Guia do Tutor" elaborado para os Cursos de Especialização em Gestão Pública Municipal, Gestão Pública e Gestão em Saúde do Programa Nacional de Formação em Administração Pública (PNAP), modalidade a distância. Abrangia conteúdos relacionados ao ensino a distância, ao papel da tutoria e também informações acadêmicas e administrativas do curso.

A primeira etapa da capacitação era voltada a apresentar o PNAP, oferecido na Universidade Federal do Rio Grande do Sul pela Escola de Administração, em parceria com o Sistema Universidade Aberta do Brasil (UAB) do Ministério da Educação. Também, nesta primeira etapa, foi apresentado o curso, abrangendo sua gestão, operacionalização, conteúdos, cronograma e sistema de avaliação.

A segunda etapa foi destinada a apresentar algumas premissas da abordagem didático-pedagógica do curso. O delineamento da estratégia didática e seus respectivos procedimentos pedagógicos levaram em consideração, especialmente, os seguintes aspectos:

- a possível heterogeneidade inerente ao perfil acadêmico e à experiência profissional dos alunos;

- a preocupação com a compatibilidade da formação acadêmica dos professores, tutores e coordenadores, em seu conhecimento sobre os temas sob sua responsabilidade; 
- a necessidade de utilização de metodologias que propiciem a adequada interação entre teoria e prática, promovendo a análise de casos concretos, o trabalho em comunidades de aprendizagem e outras atividades colaborativas e cooperativas.

Contemplados os aspectos acima, operacionalmente, a organização didático-pedagógica do curso foi pautada pelos seguintes elementos:

- sequência - apresentação do conteúdo de forma progressiva e lógica;

- abordagem passo a passo - cada assunto é tratado de forma detalhada, de modo que o pós-graduando possa compreender inteiramente o que está sendo tratado, antes de passar para o próximo tópico;

- objetividade - conteúdo apresentado por meio de linguagem clara, leve, simples e objetiva;

- exemplos - os assuntos, sempre que possível, exemplificados de modo a facilitar a ilustração das ideias, conceitos, etc.;

- exercícios de fixação - tarefas que permitam ao pós-graduando rever e aplicar os conhecimentos, bem como testar a sua compreensão do assunto estudado, utilizando formas variadas de exercícios em aula;

- feedback - nos exercícios e tarefas, é dado rápido retorno ao pós-graduando sobre o seu desempenho, se não imediato pelo sistema, então pelos tutores e/ou professores, dentro de prazos "ótimos" definidos pelo curso;

- colaboração - atividades que possibilitem aos pós-graduandos realizar trabalhos e encontrar solução conjunta de problemas, como fóruns de discussão, aulas interativas e estudos de caso;

- material impresso - conteúdo disponível para impressão (formato adequado a cada propósito);

- material audiovisual - quando necessário o conteúdo é complementado com webconferências ao vivo e palestras gravadas em vídeo, fomentando o debate teoria x prática; 
- resolução individual e em grupo de casos reais, com análise e sistematização de experiências concretas de trabalho, e com destaque para a formação de comunidades de aprendizagem em ambiente virtual;

- produção de materiais escritos e entregues eletronicamente em ambiente virtual, como resultado de análises e estudos individuais e em grupo;

- sistema de tutoria e apoio pedagógico ao desempenho de cada aluno, e aos grupos de alunos.

As disciplinas eram sequenciais e ordenadas em um módulo básico e outro específico, com avaliação de atividades a distância e presenciais. Cada professor, no âmbito e de acordo com a carga horária da sua disciplina, utilizando como material básico os fornecidos pelo programa PNAP, apresentava os conteúdos e procedia à elaboração de exercícios síncronos e assíncronos, em diversas estratégias metodológicas disponíveis, culminando na avaliação da disciplina, incluindo eventuais atividades de recuperação. As apostilas básicas fornecidas pelo programa PNAP eram um pouco antigas, e, por isso, apresentavam alguns dados defasados, sendo necessário complementar com material atualizado.

A terceira etapa da capacitação tinha como objetivo discutir a educação a distância e o papel da tutoria, culminando com o perfil desejável para o curso. Assim, foram traçadas e discutidas algumas atitudes desejáveis aos tutores que atuam em cursos a distância:

a) ser facilitador e incentivador da aprendizagem do grupo de alunos;

b) esclarecer dúvidas dos alunos quanto ao uso da plataforma e das ferramentas de softwares utilizadas no curso;

c) responsabilizar-se pela facilitação do cumprimento do programa e cronograma estabelecidos, fazendo-se respeitar o agendamento das atividades propostas; 
d) acompanhar a realização dos trabalhos e provas, e corrigir e lançar, no campo apropriado do sistema, os resultados obtidos pelos alunos, se assim definido pela coordenação do curso;

e) incentivar e favorecer a diversidade cultural do grupo, facilitando a troca de experiências e conhecimento do conteúdo estudado;

f) valorizar a participação individual, promovendo a interação e a cooperação entre os alunos, mantendo o foco nos objetivos do curso;

g) encaminhar à coordenação de tutoria eventuais problemas com o curso ou turma, tão logo ocorram;

h) participar das reuniões com as coordenações, quando convocados.

Para tanto, identificou-se as principais competências a serem desenvolvidas nos tutores, o que foi trabalhado na capacitação e nos encontros realizados durante o curso:

- domínio do conteúdo, das ferramentas/recursos de aprendizagem e da proposta do curso/disciplina;

- dedicação, responsabilidade e pontualidade;

- proatividade e preparo para imprevistos - planejamento do tempo;

- clareza e polidez na colocação das ideias;

- habilidade de mediação (saber como conduzir a atividade conforme o momento);

- certa objetividade, sem ser "superficial" ou "evasivo";

- disponibilidade (saber ouvir, responder e-mails);

- abertura ("ser acessível" e aberto às diferenças);

- postura de quem age como facilitador, e não como detentor do conhecimento;

- motivação, instigação, "provocação";

- flexibilidade na análise de situações contingenciais - "bom senso"; 
- postura gregária (é um "agregador", preocupado com os alunos enquanto grupo social);

- postura crítica, que também estimula o pensamento crítico do aluno;

- orientação ("ser um bom 'orientador'", tanto para indivíduos quanto para grupos);

Para atuar como tutor a distância era necessário ter disponibilidade de 20 horas semanais, sendo que, os tutores a distância deveria atuar em 16 horas semanais destinadas para atender alunos em sistema online, mantendo estreita correspondência com grupos sob a sua supervisão, estimulando o processo da aprendizagem a distância e fazendo a mediação entre alunos e professores. As 4 horas semanais restantes eram destinadas para estudos e reuniões, sendo que a equipe de tutores reunia-se ao menos uma vez por semana, à noite, para as atividades síncronas do curso.

Em relação às principais atividades dos tutores a distância, constava acompanhar o processo de aprendizagem dos alunos, contando com o apoio dos professores e dos tutores presenciais alocados nos polos de área de abrangência de sua turma. Cada tutor acompanhava o processo de aprendizagem de aproximadamente 30 alunos, sendo atribuições do tutor:

a) mediar a comunicação de conteúdos entre o professor e os cursistas;

b) acompanhar as atividades discentes, conforme o cronograma do curso;

c) apoiar o professor da disciplina no desenvolvimento das atividades docentes;

d) manter regularidade de acesso ao ambiente virtual de aprendizagem (AVA) e dar retorno às solicitações dos alunos no prazo máximo de 24 horas;

e) estabelecer contato permanente com os alunos e mediar as atividades discentes; 
f) colaborar com a coordenação do curso na avaliação dos estudantes;

g) participar das atividades de capacitação e atualização promovidas pela Instituição de Ensino;

h) participar do processo de avaliação da disciplina sob orientação do professor responsável;

i) fornecer feedback individual e para o grupo de alunos semanalmente;

j) se reportar ao coordenador de tutoria;

k) estar ciente e zelar pelo cumprimento do que está estabelecido no Manual do Aluno e Planos de Ensino;

l) estar ciente e zelar pelo cumprimento do que está estabelecido no código disciplinar discente.

Os tutores a distância contavam com o apoio da Coordenação de Tutoria para as questões pedagógicas e administrativas, e com o suporte técnico do curso do curso em relação ao AVA. Na percepção de mais de $75 \%$ dos acadêmicos, os Tutores a distância demonstraram ter domínio técnico dos recursos da plataforma e dos conteúdos, e incentivavam a participação dos alunos nos chats e fóruns, promovendo o debate e valorizando as contribuições de todos. Além disso, 65\% considerou que recebia retorno das atividades e dúvidas em tempo razoável, de forma clara, construtiva e objetiva. Este resultado pode ser considerado muito bom, mas ainda há espaço para melhorias.

Para atuar como tutor presencial também era necessário ter disponibilidade de 20 horas semanais, sendo que estas horas eram destinadas para atender alunos ou realizar atividades relacionadas ao curso em sistema presencial, como auxílio na utilização do ambiente virtual e administração das atividades presenciais realizadas no polo. Entretanto, uma parte desta horas deveriam ser realizadas no dia das atividades assíncronas dos cursos.

Em relação às principais atividades dos tutores presenciais constava apoiar os alunos na utilização do polo no qual estavam alocados, 
bem como no uso das ferramentas eletrônicas e do ambiente virtual do curso, contando com o apoio da coordenação do curso e da coordenação de polo, sendo atribuiç̧̃es do tutor:

a) apoiar presencialmente os estudantes na utilização do polo e nas ferrramentas disponibilizadas por este e pelos cursos;

b) administrar as atividades presenciais nos polos;

c) acompanhar as atividades discentes, conforme o cronograma do curso;

d) manter regularidade de acesso ao ambiente virtual de aprendizagem e dar retorno às solicitações dos alunos no prazo máximo de 24 horas;

e) apoiar operacionalmente a coordenação do curso nas atividades presenciais nos polos, em especial na aplicação de avaliações.

f) contatar os alunos quando solicitado pela coordenação do curso;

g) elaborar relatórios mensais de acompanhamento dos alunos e encaminhar à coordenação de tutoria;

h) participar das atividades de capacitação e atualização promovidas pela Instituição de Ensino;

i) se reportar ao coordenador de tutoria;

j) estar ciente e zelar pelo cumprimento do que está estabelecido no Manual do Aluno e Planos de Ensino;

k) estar ciente e zelar pelo cumprimento do que está estabelecido no código disciplinar discente.

Os tutores presenciais também contavam com o apoio da Coordenação de Tutoria para as questões pedagógicas, e com a secretaria e suporte técnico do curso do curso para questões operacionais e em relação ao AVA. Além disso, enviavam relatórios mensais sobre o andamento das atividades no polo e acompanhamento dos alunos. Na percepção dos alunos 63\% dos tutores presenciais ofereceram atendimento satisfatório, demonstrando que o apoio presencial é bom para a maioria, mas que precisa ser bastante aprimorado. 
Por fim, a última etapa apresentava o Ambiente Virtual de Aprendizagem utilizada pelo curso, a plataforma MOODLE Institucional da UFRGS, bem como o conjunto de recursos utilizados para o desenvolvimento das atividades acadêmicas e administrativas.

a) apresentação de informações gerais das disciplinas, turmas e qualquer outra instância, inclusive a lista de professores e alunos, com seus perfis, dados cadastrais e recados enviados por outros usuários; o recurso permite edições e impressões de listas de chamada dos alunos, ou mesmo chamadas com apontamentos de forma eletrônica, e registros de notas e conceitos;

b) plano de ensino, apresentando os conteúdos com um cronograma de atividades, podendo a esta programação serem anexado arquivos de diferentes formatos relacionados aos eventos;

c) videoaulas, disponibilizando apresentações resumidas de aulas, em vídeos digitais;

d) conteúdos (de aulas), em arquivos de diferentes formatos, como texto, apresentação e planilha eletrônica;

e) fórum temático de construção de conhecimento, disponível 24 horas por dia, para conversação assíncrona com os professores e colegas de instância (turma, ou disciplina, ou curso, etc.); permite criar tópicos de diferentes temas, e apresenta-se numa estrutura encadeada, permitindo respostas a anotações feitas, assim como respostas de respostas, até vários níveis;

f) aula interativa (chat ou webconferências), para conversação online, preferencialmente síncrona; pode ser gerada sem vídeo (chat) ou com vídeo transmitido ao vivo pelos professores (webconferências);

g) tarefas online, onde podem ser disponibilizados exercícios de diferentes tipos e formatos, para fins de aprendizagem de forma mais informal e divertida (palavras cruzadas, jogos com figuras, etc.); 
h) avaliações, para disponibilização de arquivos contendo feedbacks qualitativos ou quantitativos de avaliações, na forma de arquivos de diferentes formatos;

i) correio interno, para remessa e recebimento de mensagens, para alunos e professores selecionados; as mensagens podem ser enviadas para caixas postais internas e também para e-mails externos, conforme assinalado na página de dados cadastrais;

O curso atribuiu grande ênfase às atividades em chat, que eram realizados com toda a equipe presente no Laboratório de Informática da Escola de Administração da UFRGS. Os chats foram realizados em horário noturno, uma vez por semana, às quartas-feiras, com duração de $1 \mathrm{~h} 15 \mathrm{~min}$. Antes dos chats e equipe fazia reuniões para tratar de assuntos operacionais, pedagógicos e para debater o conteúdo que seria abordado.

Como pontos positivos da realização dos chats os tutores citaram o auxílio da Coordenadora de Tutoria e do suporte tecnológico, além da interação dos tutores entre si, que podiam trocar ideias sobre os temas abordados. Isto fez com que, desde o início, o clima de integração fosse amistoso e colaborativo. A equipe de tutoria também considera que o chat semanal, além de um recurso de ensino-aprendizagem, é uma forma de criar vínculo com os alunos, criando a sensação de turma e de encontros sistemáticos para "aulas". Desta forma, percebe-se menos evasão, que costuma ter índices tradicionalmente altos no ensino a distância.

Apesar do MOODLE ter sido avaliado pelos acadêmicos como um bom recurso, a estabilidade, confiabilidade e rapidez na transmissão de dados, bem como o suporte técnico prestado pela universidade, não foram bem avaliados. Tendo em vista a instabilidade do AVA e suas atualizações, além de problemas climáticos e falta eventual de acesso à internet, um técnico do curso permanecia no laboratório de informática durante todo o período de realização dos chats para a solução de problemas pontuais. Mesmo assim, o desempenho da 
plataforma também comprometeu o desenvolvimento de algumas atividades e, consequentemente, o trabalho desempenhando pela tutoria, que depende do ambiente para realizar o trabalho e contatar os alunos.

A Coordenação de Tutoria tinha como atribuição realizar a capacitação para os tutores; acompanhar o desenvolvimento das atividades acadêmicas do curso e apoiar os professores no desenvolvimento das disciplinas; acompanhar e supervisionar as atividades dos tutores; fazer a mediação entre Coordenação de Cursos, professores e tutores; administração dos conteúdos e atividades no AVA; encaminhamento das demandas junto à secretaria e suporte técnico; acompanhamento dos chats. Na percepção dos tutores, a Coordenação de Tutoria se mostrou um grande apoio, sempre presente e rápida nos retornos, a quem os tutores se reportavam para resolver dúvidas em relação ao curso de forma geral, e resolvendo demandas administrativas e pedagógicas. Na percepção de $80 \%$ dos acadêmicos, a Coordenação de Tutoria ofereceu atendimento satisfatório, passando as informações necessárias para o acompanhamento das rotinas do curso.

Ao final do curso, os acadêmicos que haviam sido aprovados em todas as disciplinas eram considerados aptos a realizar o trabalho de conclusão de curso (TCC). Este trabalho contava com o apoio de um professor orientador, que tinham em média 6 orientandos no curso, e de tutor a distância, que tinham em média 12 orientandos no curso. O desenvolvimento do trabalho de conclusão seria desenvolvido em três etapas originalmente, ampliada em mais uma etapa intermediária.

A primeira etapa foi realizada um ano antes do desenvolvimento do TCC e compreendeu a primeira parte da disciplina de metodologia, que visava discutir teoricamente e instrumentalizar os acadêmicos para a elaboração de um trabalho de pesquisa. Nessa etapa, os alunos deveriam também escolher um tema e, de forma independente, iniciar a busca por bibliografias e desenvolvimento teórico inicial. Aproximadamente cinco meses depois, iniciou a segunda etapa e continuação da disciplina de metodologia, na qual os acadêmicos de- 
veriam desenvolver o projeto de pesquisa com base no material pesquisado. Após a realização destas duas etapas, identificou-se que a maioria dos acadêmicos pouco se apropriou dos conteúdos de metodologia, não se dedicou à pesquisa teórica e não desenvolveu o projeto a contento. Desta forma, os alunos receberam mais seis meses para aprimorar o projeto, sendo que, no último mês, contaram com o apoio de três tutoras a distância para revisar e auxiliar na finalização desta nova etapa. Cada tutora atendeu por 30 dias um grupo de 45 alunos cada. Por fim, a quarta etapa com duração de dois meses e meio foi destinada à orientação individual.

A elaboração do TCC foi a que apresentou maiores dificuldades à Equipe de Tutoria. Na percepção dos tutores, o desenvolvimento da disciplina de metodologia com muita antecedência e de forma fragmentada dificultou a compreensão e comprometimento por parte dos acadêmicos. Além disso, quando os professores orientadores assumiram, foram solicitadas várias alterações no projeto, visto que estes não haviam orientado os mesmos, o período de orientação propriamente foi curto e a quantidade de orientandos foi considerada grande. A dificuldade de comunicação e contato com os professores orientadores também foi um ponto destacado como crítico.

Corrobora com isto a percepção dos alunos, já que $42 \%$ quando questionados, comentaram ter tido dificuldades no processo de orientação do Trabalho de Conclusão de Curso e grande parte dos comentários descritivos se referia, principalmente, ao processo de orientação e dificuldade de retorno por parte dos professores.

\section{Considerações Finais}

Para ilustrar empiricamente a prática da tutoria, identificando suas principais competências e atribuições, bem como os pontos positivos e dificuldades, foi descrita a experiência da Equipe de Tutoria da 2a Edição da Especialização em Gestão Pública Municipal pertencente ao PNAP e oferecido pela Escola de Administração da UFRGS em parceria com o Sistema Universidade Aberta do Brasil (UAB) do 
Ministério da Educação. Neste sentido, tratou-se das atribuições e competências desejáveis ao tutor, identificadas na literatura, que foram utilizadas como base para definir as estratégias e ações do curso, e apresentou-se a descrição da experiência do curso.

A revisão da literatura permitiu reunir as principais atribuições e competências do tutor, sendo de grande importância na definição do trabalho que seria realizado, bem como de seu acompanhamento. A atuação da Equipe de Tutoria se mostrou satisfatória e a descrição permitiu identificar os pontos positivos e principais dificuldades na realização do trabalho. De modo geral, a equipe de tutoria foi muito bem avaliada, sendo os índices superiores à avaliação de estrutura e AVA; planejamento e conteúdo das disciplinas; desempenho dos professores. Entre as principais dificuldades, ficaram evidente as questões relacionadas ao TCC, principalmente a realização da disciplina de metodologia com muita antecedência, a grande quantidade de orientandos e a dificuldade de comunicação com os professores orientadores.

Para que o tutor desenvolva as competências necessárias e realize plenamente suas funções, é fundamental que conheça as bases teórico-conceituais da educação a distancia, bem como sua história; que possa se apropriar dos recursos do ambiente de aprendizagem de forma sistemática e reflexiva; e que possa contar com um espaço permanente de formação e troca de experiências, acompanhados pelas coordenações de curso e demais docentes. Neste sentido, a condução da equipe mostrou-se adequada, apresentando ótimos resultados.

\section{Referências}

BRASIL. Decreto № 5.622, de 19 de dezembro de 2005. Regulamenta o art. 80 da Lei no 9.394, de 20 de dezembro de 1996, que estabelece as diretrizes e bases da educação nacional. Diário Oficial [da República Federativa do Brasil], Brasília, DF, v. 134, n. 248, 20 dez. 2005. Seção I, p. 27834-27841 begin_of_the_skype_highlightingend_of_the_skype_highlighting. 
CARNEIRO, M.L.F.; TURCHIELO, L.B. Quem é o tutor a distância. Orgs. CARNEIRO, M.L.F.; TURCHIELO, L.B. Educação a distância e tutoria: considerações pedagógicas e práticas. Porto Alegre: Evangraf, 2013. (Série EAD).

ENGELMAN, R. Guia do Tutor: Cursos PNAP UFRGS - Cursos de Especialização. Material eletrônico do curso. Porto Alegre, EA/UFRGS 2013.

FUNDO NACIONAL DE DESENVOLVIMENTO DA EDUCAÇÃO. Resolução / CD/FNDE no 8 de 30 de abril de 2010. Disponível em: http://www.fnde.gov. br/fnde/legislacao/resolucoes/item/3390-resolu\%C3\%A7\%C3\%A3o-cdfnde-n\%C2\%BA-8-de-30-de-abril-de-2010. Acesso em: 15 de novembro de 2015.

MAYA, A.B. Orientaciones básicas sobre educación a distancia y la funcion tutorial. 2 ed. San Jose, Costa Rica: UNESCO, 1993.

SCHNEIDER, D.; PEREIRA, D.F.; BERSCHT, M.; BEHAR, P.A. Competências na tutoria em educação a distância. In. CARNEIRO, M.L.F.; TURCHIELO, L.B. (Orgs.) Educação a distância e tutoria: considerações pedagógicas e práticas. Porto Alegre: Evangraf, 2013. (Série EAD).

SCHROEDER, C. Competências dos tutores (e professores) para o Curso de Graduação em Administração a Distância. Slides de Capacitação do Curso Administração. 2006. 



\section{SEÇÃO II}

\section{Trabalhos selecionados}

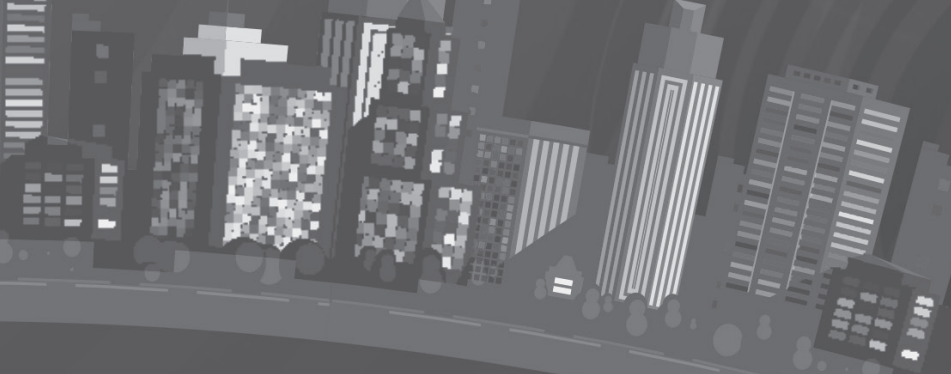




\title{
O controle interno de Nova Petrópolis: como suas recomendações são utilizadas pela administração municipal
}

\author{
Ariane Cristina Berti \\ Odair Gonçalves \\ Patrícia Tometich
}

Cada vez mais, devido à complexidade da Administração Pública $(A P)$, faz-se necessário o controle de seu aparato. Esse controle busca dar à sociedade a garantia de que os recursos obtidos através da sua contribuição serão bem e corretamente empregados, gerando retorno na forma de políticas públicas que atendam as suas demandas, tornem menores as desigualdades e mais eficientes os serviços prestados.

Para tanto, a Constituição Federal (CF) de 1988 preocupou-se em definir mecanismos obrigatórios de controle da gestão pública nos diversos níveis da Administração e um desses mecanismos é o Controle Interno $(\mathrm{Cl})$.

Em seu artigo 70 a CF, na seção que trata "Da Fiscalização Contábil, Financeira e Orçamentária", dispõe que "A fiscalização contábil, financeira, orçamentária, operacional e patrimonial [...] das entidades da administração direta e indireta, [...] será exercida pelo Congresso Nacional, mediante controle externo, e pelo sistema de controle interno de cada Poder".

Já no artigo 31, tratando especificamente do Controle Interno Municipal (CIM), a CF reza que "A fiscalização do Município será 
exercida pelo Poder Legislativo Municipal, mediante controle externo, e pelos sistemas de controle interno do Poder Executivo Municipal [... $]^{\prime \prime}$. A mesma Carta Magna, em seu artigo 74, estabelece também as finalidades do $\mathrm{Cl}$.

Na esteira constitucional, a Lei Complementar no 101, de 4 de maio de 2000, estabelece normas de finanças públicas voltadas para a responsabilidade na gestão fiscal por parte das APs em seus diversos níveis e, em seu artigo 59, determina que o Poder Legislativo, com o auxílio do Tribunal de Contas e do Sistema de Controle Interno $(\mathrm{SCl})$, serão responsáveis pela fiscalização do cumprimento das normas estabelecidas nesta lei.

O trabalho realizado pelas Unidades de Controle Interno (UCI) tem por objetivo principal a consolidação dos princípios constitucionais da Administração Pública, quais sejam: legalidade, impessoalidade, moralidade, publicidade e eficiência, tanto nos procedimentos administrativos como na utilização dos recursos públicos, ficando clara a relevância social deste trabalho.

Através de verificações realizadas junto à unidade de pesquisa, constatou-se que ocorriam reincidentes apontamentos do Tribunal de Contas do estado de Rio Grande do Sul (TCE/RS). Desta observação, surgiu a pergunta que norteou esta pesquisa: como as recomendações do $\mathrm{Cl}$ têm sido aplicadas pelo gestor público municipal de Nova Petrópolis?

O presente estudo verificou, no período de 2009 a 2013, através da análise comparativa entre os documentos elaborados pela $\mathrm{UCl}$ e os relatórios das auditorias ordinárias do TCE/RS como, na prática, o gestor público utilizou as recomendações do CIM. Buscou-se verificar a legislação sobre o $\mathrm{Cl}$, estudar os relatórios do TCE/RS e os apontamentos do $\mathrm{Cl}$ de Nova Petrópolis para então constatar como as recomendações do órgão refletiam-se na administração municipal.

Para que se possa entender o funcionamento do $\mathrm{Cl}$, é necessária a abordagem de alguns conceitos, bem como do histórico da AP no Brasil.

A AP, compreendida como todo o aparato necessário à consecução das atividades do Estado, tem-se tornado o foco dos mais diver- 
sos canais de comunicação nos últimos tempos. Escândalos financeiros envolvendo estatais e o governo, de forma direta ou indireta, têm destaque na mídia. Corrupção, superfaturamento de obras, desvio e má aplicação de recursos públicos, desperdícios variados, dentre outros, são práticas inadmissíveis, frente à sociedade que clama por políticas públicas eficientes, em especial nas áreas da saúde, educação e segurança.

Por isso, há uma constante busca, por parte de segmentos mais conscientizados, de regulamentações no sentido de dificultar estas práticas, procurando a transparência cada vez maior das atividades da Administração Pública e a aplicação de punições e sanções aos que descumprirem as normas legais.

Para Leite Junior (2009), o modelo de AP atual inicia-se no governo de Getúlio Vargas, na década de 30, quando o então Presidente remodelou a Administração e procurou dar-lhe um formato Weberiano, pondo em prática uma administração mais técnica e profissionalizada - a administração burocrática. Outro marco histórico, segundo o autor citado, ocorreu na década de 60 , com a edição do Decreto-Lei no 200. Esta legislação ressalta a importância da administração planejada e coordenada, além de reforçar a utilização de mecanismos de controle, descentralizando-a ainda mais e, dividindo-a em Direta e Indireta.

Não menos importante é a fase iniciada em 1988, com a promulgação de uma nova $C F$, que vem carregada de um espírito renovador e cidadão, trazendo em seu bojo as raízes de mais uma grande reforma administrativa (LEITE JUNIOR, 2009).

Leite Junior (2009) relata ainda que, com a implantação da administração gerencial, durante o governo do Presidente Fernando Henrique Cardoso, a AP foi reduzida ao mínimo, de acordo com os preceitos do neoliberalismo, onde o carro-chefe é o mercado.

Mas ainda não nos é possível visualizar o País sem a presença de uma AP forte, eficiente, tampouco vislumbra-se um futuro promissor a qualquer governo que não tiver suas instituições revestidas de credibilidade. 
Para tanto, utiliza-se uma das mais antigas formas de impor limites aos atos dos administradores: os "controles", que sistematicamente vem sendo reformulados e aprofundados nos textos constitucionais desde 1824 até os dias atuais. Porém, foi através da CF de 1988 e com a Reforma do Estado que ficou claro como, por quem e de que forma ele seria exercido.

O cumprimento dos princípios da Legalidade, Impessoalidade, Moralidade, Publicidade e Eficiência (este último incluído pela Emenda Constitucional no 19/1998), decorrentes da CF de 1988 e que, segundo Milesky (2003. p. 37) "[...] são padrões de conduta que devem ser seguidos pela Administração Pública, constituindo arcabouço dos fundamentos de validade da ação administrativa", reforçaram a ideia de controle.

Outro marco legislativo que determinou e definiu formas de controle dentro da AP foi a Lei no 4.320/64, que em seu capítulo VIII trata do controle da execução orçamentária, determinando, no artigo 75, que este controle compreenderá "I - a legalidade dos atos [...]; II - a fidelidade funcional dos agentes da administração [...]; III - o cumprimento do programa de trabalho [...]". No artigo 76, determina que o Executivo realizará o controle interno dos itens acima e no artigo 77, indica que esta verificação se dará de forma "prévia, concomitante e subsequente."

Ainda dentro do contexto da Lei no 4.320/64, cabe uma breve colocação sobre o orçamento público que, para Milesky (2003, p. 44), tem o seguinte significado "[...] o orçamento público deixou de ser apenas um instrumento de controle parlamentar sobre a receita e a despesa governamental, para tornar-se um elemento que expressa, em termos financeiros, um planejamento [...]".

Citando apenas os principais marcos legais, depreende-se que o controle da Administração sempre foi uma preocupação e, colocá-lo em de normas legais deixa claro seu caráter obrigatório, além de propiciar o controle de um Poder pelo outro.

Especificamente no âmbito do controle municipal, o artigo 31 da CF de 1988 determina que "A fiscalização do Município será exercida 
pelo Poder Legislativo Municipal, mediante controle externo, e pelos sistemas de controle interno do Poder Executivo Municipal, na forma da lei".

Apesar da determinação constitucional, somente no ano de 2000, após a edição da Lei de Responsabilidade Fiscal (LRF), que obrigou o gestor público a publicar periodicamente, com o aval do $\mathrm{Cl}$, relatórios de gestão fiscal e execução orçamentária, sob pena de ser responsabilizado e de ter que arcar com multas ou com o não recebimento de verbas da União e do Estado, é que as UCls começaram a ser instaladas nos municípios.

A Lei Complementar no 101/2000, conhecida como Lei de Responsabilidade Fiscal, segundo Milesky (2003, p. 64) "[...] trouxe um disciplinamento de caráter inovador e abrangente $[\ldots]$ ", regulamentando diretrizes, metas e limites, além de definir procedimentos a serem seguidos pelo gestor "[...] com normas sobre transparência e controle da gestão fiscal, estabelecendo, inclusive, sanções por infrações às disposições normadoras [...]".

Milesky (2003, p. 65) afirma ainda que "[...] a estrutura normativa da Lei Complementar 101/2000, basicamente, está assentada em quatro pilares de sustentação: planejamento, transparência, controle e sanção".

Na busca desses objetivos, o TCE/RS editou algumas Resoluções como segue: a Resolução no 936, de 13 de março de 2012 que dispõe sobre a estruturação e funcionamento dos $\mathrm{SCl}$ municipais; a Resolução no 979 de 22 de maio de 2013 que torna obrigatória a manifestação do Cl para acompanhar os Relatórios de Gestão Fiscal do Executivo e Legislativo municipais; e a Resolução no 1.006 de 5 de fevereiro de 2014 que deixa clara a possibilidade de emissão de parecer prévio desfavorável ou julgamento pela irregularidade das contas do gestor pelos atos praticados e elencados em seus incisos.

Enfocando-se mais diretamente a questão do controle Milesky (2003, p. 137) afirma que "A função de controle do poder foi estruturada no estado moderno, quando se consolidou como uma das principais características do Estado de Direito". 
Segundo Milesky (2003), o controle pode ser interno ou externo, conforme for efetuado por órgão integrante ou não da estrutura administrativa do Poder. O controle interno, também conhecido como controle Administrativo, é exercido pelos $\mathrm{SCl}$ constituídos dentro dos órgãos das diversas esferas de governo. O controle externo, por sua vez, está a cargo do Legislativo e é realizado com o auxilio dos Tribunais de Contas em suas respectivas esferas de competência, além do controle Judiciário que atua por provocação.

Milesky (2003) ressalta ainda que o controle pode ser prévio: quando se antecipa a realização do ato administrativo; concomitante: quando ocorre juntamente com o desenrolar da atividade administrativa e a posteriori, ou seja, após a realização dos atos administrativos, como no caso das auditorias ordinárias do TCE/RS nas prefeituras.

O controle também pode ser analisado quanto à finalidade, como de legalidade (onde se verifica o cumprimento deste princípio) ou de mérito, que "[...] busca verificar o resultado da ação administrativa na consecução dos fins do Estado, avaliando a eficiência, eficácia e a economicidade dos atos praticados, tendo em conta a conveniência e a oportunidade dos mesmos" (MILESKY, 2003, p. 147).

Portanto, a importância do controle dos atos administrativos se verifica, não apenas como forma exclusiva de levantar irregularidades e assim aplicar sanções aos que descumprirem as normas legais, mas também no sentido de auxiliar na boa execução do planejamento e aplicação dos recursos providos pela sociedade.

O SCl do município de Nova Petrópolis foi instituído pela Lei $\mathrm{n}$ 2.874 de 21 de dezembro de 2001, posteriormente revogada pela Lei $\mathrm{n}^{\circ} 3.466$ de 14 de outubro de 2005, atualmente em vigor com as alterações provocadas pela Lei no 4.055 de 25 de fevereiro de 2011. O Regimento Interno (RI) do SCI foi homologado pelo Decreto no 82 de 20 de abril de 2011.

A Lei Municipal no 3.466/2005 integra o SCl à estrutura do gabinete do Prefeito, define suas atribuições, que estão descritas no art. $2^{\circ}$ e em consonância com os artigos 31, 70 e 74 da CF, a composição, periodicidade das reuniões, a obrigatoriedade de seus membros 
serem servidores concursados e efetivos e também a gratificação a que fazem jus pelo cumprimento deste que é considerado "relevante serviço público obrigatório." (NOVA PETRÓPOLIS, 2005, art. 6ำ).

Ressalta-se também, no artigo 4을 desta norma, a obrigatoriedade da composição da $\mathrm{UCl}$ por servidores do quadro efetivo do município ou cedidos pelo Estado ou pela União, desde que sejam obedecidos os requisitos definidos na lei para a nomeação. A UCl será composta por três integrantes, sendo um Coordenador, um contador ou técnico em contabilidade e um servidor com, no mínimo, ensino médio completo, sendo os dois últimos obrigatoriamente do quadro permanente de servidores municipais. O Coordenador deverá desempenhar a função em horário integral, enquanto que os demais o farão concomitantemente com as do cargo de origem.

Existe em trâmite no Executivo uma proposta de alteração da legislação, que estrutura o $\mathrm{Cl}$ de Nova Petrópolis no sentido de adequá-lo às determinações da Resolução no 936/2012 do TCE/RS, que define as diretrizes a serem observadas para a estruturação e funcionamento do $\mathrm{SCl}$ dos municípios.

Especificamente com relação a UCl do município em estudo, verificou-se que, do ponto de vista legal, estão cumpridos os requisitos básicos necessários ao seu funcionamento, com ressalva para o projeto ainda em tramitação. No entanto, do ponto de vista do aspecto físico, o trabalho de seus membros têm sido prejudicado pelas condições bastante precárias, visto que não possuem local adequado e exclusivo de trabalho, tendo que organizar suas reuniões conforme disponibilidade de agenda da sala de reuniões geral e a servidora que atua em horário integral na Unidade fica alocada no setor de Contabilidade; também não há local para guarda de documentos, livros, relatórios e demais materiais da $\mathrm{UCl}$, ficando os mesmos depositados em caixas ao longo do corredor no segundo andar do prédio da Prefeitura.

Passando-se a questão metodológica, optou-se nesta pesquisa por um estudo de caso de cunho exploratório (GIL, 2002), visto que não se tem conhecimento de outros estudos com o mesmo enfoque; 
decidiu-se pela pesquisa qualitativa, utilizando-se como procedimento técnico de coleta de dados a pesquisa documental, interna e externa à organização.

A documentação externa constituiu-se do acervo bibliográfico publicado até o momento, no que tange à legalidade, obrigatoriedade e importância do $\mathrm{Cl}$ dentro da $\mathrm{AP}$, bem como dos relatórios de auditoria ordinária do TCE/RS produzidos após as inspeções periódicas realizadas por aquele órgão na Prefeitura de Nova Petrópolis.

No tocante à documentação interna, houve a análise das Atas, Relatórios de Verificação, Memorandos e Pareceres elaborados pela $\mathrm{UCI}$ no período de verificação, vinculados ao atendimento dos objetivos propostos pela pesquisa.

A amostra de estudo constitui-se dos relatórios de auditoria ordinária do TCE/RS e da documentação do Cl elaborada no período de 2009 a 2013.

O período de cinco anos, para a análise da documentação, foi estabelecido por considerar-se um prazo razoável e com condições de apresentar informações robustas e diversificadas, de modo a enriquecer e demonstrar parte dos inúmeros aspectos evidenciados num trabalho de auditoria do porte deste realizado pelo TCE/RS.

A análise dos dados iniciou-se pela verificação dos relatórios de auditoria ordinária do TCE/RS emitidos para o período de 2009 a 2013. Preliminarmente foram apartados os relatórios que continham, em anos distintos, apontamentos semelhantes sobre o mesmo assunto ou, basicamente, com a mesma fundamentação legal. Buscou-se os apontes que se repetiram em mais de um período indicando que a irregularidade vista anteriormente permanecia sem solução aceitável pelo controle externo.

Para atender ao objetivo de verificar como o gestor vinha utilizando as recomendações do CIM foram analisados os Memorandos, Relatórios, Relatórios de Verificação e Pareceres elaborados pela UCl de Nova Petrópolis, que versassem sobre o mesmo assunto dos apontes constantes nos relatórios do TCE/RS. Buscou-se neste material quais a recomendações elaboradas e encaminhadas ao 
gestor por parte do $\mathrm{Cl}$ com referência as irregularidades elencadas pelo controle externo.

A seguir, foi feita a comparação entre as sugestões indicadas pela $\mathrm{UCl}$ e os apontamentos encontrados nos relatórios do TCE/RS, para concluir de que forma o gestor utilizou as recomendações do CIM.

Os relatórios de inspeção do TCE/RS listam em forma de itens e subitens as diversas inconformidades apontadas e do material verificado destacou-se para a pesquisa os pontos que se passa a relatar.

No quesito DESPESA, repetiram-se os apontes do TCE/RS em dois subitens: "Intermediação de mão de obra" - este dividindo em dois subitens: "burla ao concurso público" e "distorção na despesa com pessoal" - e "Terceirização irregular de assessoria jurídica". O primeiro apareceu nos relatórios de 2009 e 2010. O outro, "Terceirização irregular de assessoria jurídica", foi apontado nos relatórios de 2012 e 2013.

Seguindo-se a análise dos apontes, o item "Sistema de Controle Interno" foi levantado na inspeção do TCE/RS e listado nos relatórios de 2009 e 2010.

No item "Convênios, Ajustes e Temos de Cooperação/Parceria" os apontamentos que ocorreram nos cinco anos analisados, deramse sobre o Termo de Parceria firmado entre a Prefeitura e a Associação de Turismo e Meio Ambiente - ATURMA, em três subitens: "Contratação de pessoal sem concurso", nos anos de 2009 a 2013; "Distorção com gastos de Pessoal", em 2009 e 2010 e "Disponibilização de pessoal em desacordo com o plano de trabalho", nos anos de 2010 e 2011.

O próximo item dentro da "Administração de Pessoal", que foi apontado como irregularidade de 2009 a 2013, foi a contratação de "Cargo em Comissão de Assessor Jurídico".

Na matéria Licitações e Contratos, foi analisado e apontado pelo TCE/RS em 2009, 2010 e 2011 o que consta no subitem "Aquisição de peças para manutenção de veículos e máquinas sem licitação". 
O penúltimo item levantado pela auditoria e destacado neste estudo refere-se a "Gestão Ambiental", no subitem "Falta de fiscalização da reposição florestal", nos anos de 2009 e 2012.

O último item a ser verificado: "Obras de Engenharia", apontado em 2011 e 2012 em função de "Irregularidades na obra da escola de educação Pró-Infância".

Analisou-se a documentação produzida pelo CIM de Nova Petrópolis de 2009 a 2013, num total de 588 documentos entre Atas, Pareceres, Relatórios, Relatórios de Verificação e Memorandos, elaborados no período de estudo da pesquisa.

Percebe-se pelo número de "Atas" (total de 235), que os encontros semanais previstos na legislação ocorreram de forma relativamente uniforme nos anos verificados, com destaque para o ano de 2012 em que ocorreram 55 reuniões da equipe, portanto um pouco acima da média.

Os "Pareceres", que perfizeram 42 documentos, versam em sua maioria sobre a apreciação do $\mathrm{Cl}$ referente a aplicação de recursos de convênios diversos realizados entre o município e o governo do Estado do Rio Grande do Sul ou a União, além daqueles que acompanharam as contas anuais do Prefeito, conforme determinado no artigo 113, II, b e artigo 113, III, b, ambos da Resolução n 544 de 21 de julho de 2000 - Regimento Interno do TCE/RS sobre a aplicação de recursos nos percentuais mínimos obrigatórios para Manutenção e Desenvolvimento do Ensino (MDE) e Ações e Serviços Públicos de Saúde (ASPS).

A exceção encontra-se nos Pareceres do ano de 2011, onde os de no 1 e 2 tratam de externar a opinião do órgão de Cl sobre a realização de Licitação no ano de 2011 para despesas constantes no orçamento de 2012; os pareceres de no 3 a 7 tratam de expor a posição do CIM sobre a realização de despesas de alimentação em eventos turísticos ou ligados ao Centro de Atenção Psicossocial (CAPS); no parecer $n \circ 8$ o $\mathrm{Cl}$ opinou sobre a legalidade da contratação de serviço de sonorização para eventos do município, mas alertou para a observação de realização de licitação como forma mais adequada de obter estes serviços. 
Dos 56 "Relatórios" elaborados nos períodos verificados, alguns se repetiram em seu conteúdo, por serem documentos obrigatórios e que acompanharam as Prestações de Contas do gestor, quais sejam, os que demonstraram a base de cálculo utilizada pela administração para estabelecer os percentuais mínimos legais a serem repassados para a Educação e Saúde (MDE e ASPS), os relatórios que evidenciaram a consistência dos $\mathrm{SCl}$ do Executivo e os que opinavam sobre a execução orçamentária e contábil do Poder Legislativo. Os destacados pela pesquisa foram os de no 06/2009, 03/2012, 05/2013 e 11/2013,

A partir de 2011 os relatórios que analisaram as contratações temporárias ou emergenciais também começaram a ser elaborados sistematicamente a cada bimestre, visto que este documento passou a ser anexado ao relatório proveniente do Departamento de Pessoal e encaminhado ao TCE/RS através do Sistema Informatizado de Auditoria de Pessoal (SIAPES).

$\mathrm{Na}$ análise dos 72 "Relatórios de Verificação" constatou-se que nos anos de 2009 e 2010, estes documentos não eram elaborados passando a sê-lo a partir de 2011.

Neles é que foram encontrados os principais pontos de destaque para a comparação entre o trabalho da UCl e os relatórios da auditoria externa, pois neles são verificados itens e procedimentos administrativos, suas rotinas e consistências, bem como são encaminhadas as recomendações e orientações ao gestor para a correção de pontos que possam sofrer apontes.

Finalizou-se a análise dos documentos do CIM, com a verificação dos "Memorandos", que perfizeram 127 documentos. Eles foram utilizados para diversas finalidades dentre as quais a solicitação de informações, encaminhamento de relatórios e documentos, pedido de documentação para análise do $\mathrm{Cl}$, encaminhamento de questionários do TCE/RS, porém, a partir de 2011 também foram utilizados para sugerir providências ou encaminhar recomendações. Por este motivo também foram destacados alguns destes memorandos para análise mais aprofundada. 
De toda a documentação analisada mereceram destaque os "Relatórios" 06/2009, 03/2012, 05 e 11 de 2013. Dos "Relatórios de Verificação" destacaram-se os que tratam sobre Serviços de Oficinas, todos de 2012; Serviços da COOPESUL, 2011 e 2012; o que trata da Resolução no 936/2012 do TCE/RS sobre a estrutura do Cl de no 17/2012; os relatórios 60 e 64 de 2012 sobre obras públicas e referente a construção da creche.

Nos "Memorandos" destacou-se o n 01/2009 sobre a ATURMA; no 05 e 09 de 2011, sobre a COOPESUL e o no 18/2011, que faz alusão à realização de concurso público. Destacou-se o no 17 sobre a COOPSUL; os de no 21, 30, 34 e 36 que tratam de despesas realizadas com oficinas e o de $n^{\circ} 32$ que faz recomendações sobre a construção da Escola de Educação Infantil Pró-Infância, todos de 2012. Em 2013, o no 02 e 06 que sugere a realização de concurso público; o no 03 que trata da Resolução no 936/2012 do TCE/RS e o no 20 que encaminha o relatório sobre o Meio Ambiente, com recomendações.

Passa-se agora a análise descritiva desta documentação.

Aponte 1 - Intermediação de Mão de obra - Burla ao concurso público e distorção com despesa de pessoal, ambos em 2009/2010.

Este apontamento do TCE/RS demonstrou que a auditada vinha mantendo contrato com as cooperativas de trabalho COOMTAAU e COOPESUL para obtenção de mão de obra em diversas atividades necessárias ao funcionamento e manutenção de serviços públicos, como assistência social, atendimento turístico, psicológico e educacional, serviços de limpeza, dentre outros, através da prorrogação de contratos existentes, mediante dispensa de licitação ou através de novos contratos gerados por processo licitatório do tipo concorrência pública.

Foram expostas as atividades terceirizadas, serviços prestados por cada um dos contratados, cargos legalmente criados e número de vagas em cada um, compatíveis com as atividades de- 
senvolvidas pelos cooperados. Fundamentado no art. 37, II da CF a auditoria afirmou que "[...] a sistemática de alocar pessoal via terceirização de mão de obra para atender as demandas permanentes e típicas do Setor Público, por si só caracteriza dissimulação na aplicação dos preceitos constitucionais [...]" (RIO GRANDE DO SUL, 2010, p.8).

Ainda, evidenciou a distorção havida no registro contábil de despesas de pessoal, visto que os custos das contratações através das cooperativas vinham sendo lançados como "Serviços de Cooperativas e afins" quando, no entender da equipe, estes gastos deveriam fazer parte dos gastos com pessoal, devido a sua natureza. Se assim ocorresse, estes valores estariam computados no montante considerado para o cálculo dos limites com gastos de pessoal da LRF. Nos relatórios de 2009 e 2010 o montante a ser contabilizado como despesa de pessoal e que não vinha sendo considerado totalizou $\mathrm{R} \$ 1.116 .193,29$, conforme o levantamento constante no processo 4880-0200/09-2, p. 14 e processo 10280200/10-0, p. 11.

Dos papéis do $\mathrm{Cl}$ que tratam do assunto "Cooperativas", destacam-se os Relatórios de Verificação ํo 06, 07, 08, 09, 10, 11, 12, 13 e 14 de 2011 e os de no 08, 10, 11, 20, 28, 36 e 43 de 2012, os Memorandos no 05 e 09/2011 e 17/2012.

Todos os documentos tratam apenas da COOPESUL e são relatórios de acompanhamento das atividades contratadas, onde o Coordenador do $\mathrm{Cl}$ conferiu planilhas de horas trabalhadas, atividades executadas e seus valores, em comparação com o constante nos contratos provenientes das licitações.

O memorando no 05/2011 responde a uma solicitação do Gabinete do Prefeito para que o $\mathrm{Cl}$ acompanhe a realização dos serviços da COOPESUL; o de $n^{\circ}$ 09/2011 recomenda melhor preenchimento das planilhas e o no 17/2012 que se verifiquem alguns valores que possam ter sido pagos com índice de correção monetária aplicada em prazo diferente ao do contratado. 
Aponte 2 - Terceirização irregular de Assessoria Jurídica, em 2012/2013, ainda dentro do item Despesa.

O TCE/RS identificou a contratação de escritório para prestação de serviços na área jurídica cujas atividades ultrapassavam a simples assessoria. Segundo os auditores os serviços jurídicos prestados são considerados "atividade essencial na estrutura administrativa" e, portanto, deveriam ser exercidas por funcionário de carreira.

Não foram localizados papéis do $\mathrm{Cl}$ com referências a este aponte.

Aponte 3 - Sistema de Controle Interno - Deficiência na estrutura, em 2009/2010, que trata do Cl especificamente.

Este item apresentou diversas deficiências na estrutura do CIM, como falta de atualização da legislação no tangente a estrutura organizacional e as atribuições dos membros do $\mathrm{Cl}$, falta de treinamento, de segregação de funções, que o cargo de auditor criado legalmente encontrava-se vago, que os trabalhos desenvolvidos pelo $\mathrm{Cl}$ eram puramente formais visto que realizados apenas sobre documentos, que havia falta de tempo para o desenvolvimento das atividades do $\mathrm{Cl}$, devido a realização das tarefas concomitantemente às funções dos cargos de origem, que não havia acompanhamento dos processos de sindicância e tomada de contas, que havia prejuízo nos registros contábeis por falta de controles administrativos efetivos, dentre outros.

O relatório do TCE/RS de 2010 reforçou as deficiências quanto à composição e formação dos membros do $\mathrm{Cl}$, destacando que não havia determinação de escolaridade mínima para o coordenador, que desempenharia de forma exclusiva as atividades do $\mathrm{Cl}$, em detrimento dos demais membros, o que segundo os auditores "[...] denota um descaso com a formação de um Sistema de Controle Interno capaz de desenvolver de forma permanente uma fiscalização sobre os atos praticados no âmbito da administração." (RIO GRANDE DO SUL, 2011, p. 13).

Do trabalho do CIM no período, os Relatórios de Verificação ํㅡㄴ 17/2012 e o Relatório no 05/2013, além do Memorando no 03/2013 trataram deste assunto, solicitando a Administração providências 
para regularizar as funções, estrutura, composição e atribuições de seus membros, adequando a realidade municipal á Resolução no 936/2012 do TCE/RS.

Aponte 4 - Convênios, Ajustes e Termos de Cooperação/Parceria - todos relacionados à ATURMA, sendo que o aponte sobre a contratação de pessoal sem concurso repetiu-se de 2009 a 2013, distorção com gastos de pessoal, em 2009/2010 e disponibilização de pessoal em desacordo com o plano de trabalho, em 2010/2011.

Este aponte refere-se exclusivamente a ATURMA, OSCIP conveniada com o município para o atendimento da educação infantil e ensino fundamental, na faixa etária de 4 meses a 5 anos e 11 meses, oferecendo alimentação, hospedagem e educação, em 11 escolas do município, através do repasse de verbas feito pela Prefeitura.

Segundo os auditores, o município estaria se furtando a desempenhar seu papel constitucional de provedor e mantenedor da educação infantil no momento em que terceirizou esta atividade demonstrando descaso com o cumprimento desta obrigação em desacordo com o artigo 30, VI da CF reforçado pelos Pareceres no 29/2007 do TCE/RS e MPE/TCE no 151/2008. Além disso, esta forma de contratação burla o concurso público.

Com relação a distorção com gastos de pessoal, a auditoria levantou o montante de $\mathrm{R} \$ 589.034,96$, no ano de 2009 , que não fora computado como despesa com pessoal, pois estava sendo registrado pela contabilidade como "Instituições de Caráter Assistencial, Cultural e Educacional", prejudicando assim o cálculo dos limites previstos pela LRF. Em 2010 este mesmo aponte revelou um montante de $\mathrm{R} \$ 1.254 .370,19$ que deixou de ser classificado como despesa com pessoal.

No que se refere a "Disponibilização de pessoal em desacordo com plano de trabalho", foi verificado pela auditoria que a ATURMA deveria disponibilizar 52 professores que foram substituídos por técnicos de desenvolvimento infantil, sem qualquer oposição por parte da auditada. 
Feito o levantamento dos trabalhos do $\mathrm{Cl}$, verificou-se que o Relatório no 06/2009 e os Memorandos no 01/2009 e 18/2011 tratavam do assunto. O Relatório apresenta um trabalho sobre convênios do município com diversas entidades, sendo uma delas ATURMA, no entanto limita-se, quanto a esta, a cobrar documentos que deixaram de constar nas prestações de contas da entidade e recomenda a implementação do Manual de Procedimentos Operacionais relativos às Transferências Concedidas.

No Memorando no 01/2009 há uma nova cobrança de documentos para a prestação de contas, dentre eles os comprovantes de recoIhimento do INSS patronal por parte da associação e também orienta a Administração a cobrar da instituição o correto preenchimento de planilhas de controle e guarda de documentos.

No Memorando no 18/2011, o Coordenador do Cl sugere a contratação de pessoal concursado, não como forma de sanar a presente irregularidade, mas para fazer cumprir, pela Administração, os percentuais mínimos exigidos pela legislação para a área da Educação.

Com relação ao terceiro aponte, "Disponibilização de pessoal em desacordo com os termos do convênio", não foram localizados quaisquer documentos discutindo, trabalhando ou recomendando neste sentido.

Aponte 5 - Administração de Pessoal - Cargo em comissão de Assessor Jurídico, apontado de 2009 a 2013.

Neste aponte, o TCE/RS expõe que o trabalho realizado pelo cargo comissionado é efetivamente o de Procurador do município e que, por sua necessidade contínua e natureza das atividades, deveria ser desempenhado por servidor de carreira, ou seja, além de não poder ser enquadrado como cargo destinado as funções de chefia, direção e assessoramento ainda burla o concurso público.

Os trabalhos do Cl não fizeram qualquer menção ou recomendações com referência ao aponte citado. 
Aponte 6 - Licitações e Contratos - Aquisição de peças para manutenção de veículos e máquinas sem licitação, em 2009, 2010 e 2011.

Neste aponte a auditoria do TEC/RS demonstrou que a auditada, apesar de realizar licitações para contratação de serviços de oficina, não previu nas mesmas a aquisição de peças de reposição que possam ser necessárias e complementares aos serviços de mão de obra.

Isto fez com que fossem apresentadas diversas despesas referentes a compra de peças, que nos seus limites individuais permaneciam dentro do previsto na Lei de Licitações para dispensa, porém se somadas no período ensejariam a realização de licitação para o item "Aquisição de peças". Ressalta ainda a auditoria que até o final de 2009 a auditada havia pago aos contratados o valor de $\mathrm{R} \$ 1.350 .635,17$ (incluindo serviços, peças e lubrificantes); em 2010 o montante gasto apurado foi de $R \$ 1.255 .577,34$ e em 2011, somente em peças foi gasto $R \$ 1.189 .915,38$.

O trabalho do $\mathrm{Cl}$ sobre o assunto "Oficinas" pode ser verificado nos Relatórios de Verificação no 03, 09, 13, 22, 32, 38, 53, 61, 67 e 71 de 2012, Relatório no 03/2012, Memorandos no 21, 30, 34 e 36 de 2012.

Para melhor compreensão do trabalho do $\mathrm{Cl}$ convém ressaltar a edição, pela auditada, dos Decretos no 126/2011 e no 094/2012, além da Ordem de Serviços publicada em julho/2011. Nesta legislação são definidos parâmetros para a aquisição de peças e lubrificantes, com orientação para serem observados os limites de valores para consertos individuais de automóveis, máquinas, caminhões e veículos de transporte coletivo, exigindo-se um ou mais orçamentos (conforme o valor da aquisição da peça/lubrificante) ou encaminhamento para licitação, caso ultrapassem o limite definido na Lei no 8.666/93, de $\mathrm{R} \$ 8.000,00$. Importante frisar que para o conserto é necessária à anuência do servidor designado para tanto, bem como emissão de empenho prévio e específico.

Observando-se o trabalho da auditoria interna, viu-se que todos os documentos relacionados anteriormente refletem a conferência realizada pelo $\mathrm{Cl}$ das aquisições de peças e lubrificantes, com relação aos limites impostos pelos Decretos e Ordem de Serviço e as reco- 
mendações, constantes dos memorandos, fazem menção a obrigatoriedade de empenho prévio e específico para os serviços e compras, mesmo nos casos em que a origem seja os contratos provenientes das licitações de serviços de oficina.

Aponte 7 - Gestão Ambiental - Falta de fiscalização da reposição florestal, em 2009/2010.

Ao efetuar a verificação dos alvarás e autorizações de desmatamento e corte de árvores, emitidos entre 2006 e 2009, a auditoria externa constatou que uma das condições para a permissão de derrubada das árvores fosse o replantio das mesmas nativas, calculadas proporcionalmente à área autorizada. Existe no município legislação regulamentando o replantio, estabelecendo prazos de carência, ou a compensação.

Ficou evidenciado falta de fiscalização por parte da Prefeitura no tocante a verificação do replantio.

Este aponte se repetiu no relatório do ano de 2012, após a análise dos auditores sobre três processos da Secretaria de Agricultura e Meio Ambiente e informações da secretaria de que a Prefeitura não vem realizando esta fiscalização em detrimento do estabelecido na legislação municipal.

Os documentos do CIM sobre o assunto foram: Relatório no 11/2013 e Memorando no 20/2013. Neles verificou-se um trabalho amplo e abrangente a respeito de diversas questões pertinentes ao meio ambiente que dizem diretamente com as atribuições da Secretaria Municipal de Agricultura Meio Ambiente. Também foram apontados, clara e diretamente, ao gestor municipal a necessidade de fiscalização do replantio das mudas de árvores nativas autorizadas ao corte e a imprescindível urgência na contratação de fiscal específico para a área.

Aponte 8 - Obras e Serviços de Engenharia - Irregularidades na obra da escola de educação infantil Pró Infância, em 2011 e 2012.

Este é o último aponte com base no levantamento feito nos relatórios de auditoria ordinária do TCE/RS e reporta irregularidades na 
obra da Escola de Educação Infantil Pró Infância, construída através de convênio firmado entre a Prefeitura e o FNDE, em 2008.

Feita a licitação, a primeira etapa da obra ficou a cargo da Contepa Construções Ltda com prazo de 5 meses para entrega. Após 7 aditamentos e sem o cumprimento do previsto foi rescindido o contrato com a empresa em janeiro de 2012. A esta altura os gastos já superavam o montante orçado em mais de 158 mil reais.

A segunda etapa foi licitada mesmo sem ter sido finalizada a primeira e a ganhadora do certame foi a Engeporto Projetos e Construções Ltda, que também teve seu contrato rescindido em junho de 2012, sem concluir adequadamente sua etapa da construção.

Para a terceira etapa da construção foi ganhadora, em 2012, a Construtora Winter Steffens Ltda, que acabou por realizar os serviços inconclusos das etapas anteriores.

Ao final a auditoria apurou um potencial prejuízo ao erário no valor de $\mathrm{R} \$ 65.361,10$ pelo pagamento em duplicidade de itens da segunda e terceira etapas da construção, além do desrespeito aos princípios da legalidade, eficiência e economicidade, pela falta de planejamento da auditada ao definir serviços a serem prestados numa etapa que dependiam de outros que não estariam previstos em etapas anteriores.

$\mathrm{O} \mathrm{Cl}$, a respeito desse assunto, elaborou os Relatórios de Verificação n 60 e 64 de 2012 e o Memorando nํ 32/2012. Nos relatórios foram verificados os processos licitatórios no 57/2011 e 71/2012, com um levantamento sobre as empresas encarregadas de cada etapa, medições, valores pagos, pendências e aditamentos realizados. 0 Memorando tratou de recomendar a observação quanto a modalidade de licitação e que constassem nos contratos que os pagamentos, quando dependessem de repasses da União ou do Estado, seguiriam um calendário dependente do recebimento destes recursos pelo município.

Em suma, dos onze itens, somados os apontes e seus subitens, destacados dos relatórios de auditoria ordinária do TCE/RS no período de 2009 a 2013, o Cl não se pronunciou especificamente em 
oito deles, quanto aos demais, pronunciou-se efetivamente em dois e parcialmente em um.

Com relação a COOPESUL, quanto "a burla ao concurso público" e "distorção com gastos de pessoal", a Administração não realizou concurso para suprir as vagas dos cargos legalmente criados e seguiu utilizando a mão de obra cooperativa até a rescisão dos contratos em 2012, de acordo com informações da Secretaria de Administração. Quanto aos gastos com pessoal em 2012 a contabilidade passou a incorporar parcialmente estes valores aos gastos com folha de pagamento do município conforme informações obtidas junto ao Setor.

No caso da terceirização de assessoria jurídica a Administração municipal não alterou seus procedimentos e até o momento permanece com a mesma empresa de assessoria contratada à época prestando serviços jurídicos, de acordo com informações da Secretaria de Administração.

As deficiências estruturais do $\mathrm{Cl}$ permanecem apesar das manifestações de seus membros sobre o assunto em duas ocasiões. Na primeira geraram-se alterações na legislação, mas de forma incompleta. Da segunda, gerou-se um anteprojeto de lei que ainda tramita no Executivo. Além disso, ficou clara a falta de estrutura física da equipe que não possui local de trabalho adequado e condições de guarda e arquivamento de seus papéis de trabalho.

Com relação ATURMA, nos pontos levantados pela auditoria externa: "burla ao concurso público", "distorção com gastos de pessoal" e "disponibilização de pessoal em desacordo com o plano de trabalho" do termo de parceria, a Administração foi alertada a nomear concursados da área da Educação somente com a finalidade de cumprir com os percentuais legais mínimos. Houve realização de concurso somente no ano de 2014. Os gastos com pessoal, a exemplo dos serviços cooperativados, passaram a ser registrados pela contabilidade dentro da folha de pagamentos da Prefeitura, a contar de 2012, conforme informações obtidas junto ao Setor. Sobre o terceiro subitem não foi possível qualquer verificação nos documentos analisados. 
O mesmo termo de parceria continua vigendo entre o município e ATURMA, porém somente para cinco escolas, conforme informações da Secretaria da Educação, e o manual de procedimentos foi implementado pela Administração.

A permanência de assessor jurídico como cargo comissionado é ainda uma realidade no município e apesar do cargo ter sido extinto houve a criação de outro, pela Lei no 4.319/2013, que desenvolve as mesmas funções na prática.

Os serviços de oficina permanecem sendo realizados por empresas vencedoras de processos licitatórios, porém a aquisição de peças, objeto dos apontes do TCE/RS, ainda ocorrem com base nas orientações constantes dos Decretos e Ordem de Serviço editados à época, conforme confirmou-se com a Secretaria de Administração.

Quanto a fiscalização da reposição florestal, após a trabalho realizado em 2013 pelo $\mathrm{Cl}$, houve a realização de concurso público em 2014 com a nomeação de Fiscal Ambiental e esta atividade tende a iniciar-se no município.

As obras da Escola de Educação Infantil Pró Infância foram finalizadas em 2012 com a entrega do prédio à comunidade, no entanto a Prefeitura moveu processo judicial contra a empresa Contepa, responsável pela execução da primeira etapa da obra, por infração contratual buscando-se o ressarcimento de valores pela má execução dos serviços, conforme verificou-se junto ao Setor de Tributos da Secretaria da Fazenda do município.

Além da documentação relatada destacam-se os Memorandos no 02 e 06 de 2013, que apesar de não referirem-se a nenhum dos apontamentos elencados especificamente, recomenda ao gestor a contratação de servidores por meio do concurso público.

Em 2014 realizaram-se dois concursos para os cargos de: agente comunitário de saúde, agente tributário, arquiteto, auxiliar de desenvolvimento infantil, contador, eletricista, enfermeiro, engenheiro civil, farmacêutico, fiscal ambiental, fisioterapeuta, fonoaudiólogo, mecânico, médico (geral e especializações), monitor educacional, motorista, operador de máquinas, operário especializado, pedago- 
go, professores, recepcionistas, supervisor escolar, técnico de enfermagem, terapeuta ocupacional e tesoureiro e em 2015 iniciaram-se as nomeações. Pode-se verificar esta informação com base na publicação dos editais de concursos no 001/2014 e n 002/2014 no site oficial do município.

Conclui-se que o CIM tem apresentado uma boa produção, principalmente desde 2011 quando passou a contar com um membro com dedicação exclusiva. No entanto, a sincronia do seu trabalho com relação aos apontes do TCE/RS tem deixado a desejar.

Com relação ao problema da pesquisa: como o gestor de Nova Petrópolis vem aplicando as recomendações do $\mathrm{Cl}$ nota-se que algumas delas foram acatadas, mesmo que tardiamente, como no caso da implementação do Manual de Procedimentos Operacionais Relativos às Transferências Concedidas, a realização de concurso público e a as alterações ocorridas na legislação do $\mathrm{Cl}$. Porém, não houve orientações específicas condizentes com os apontes da auditoria externa destacados pela pesquisa, o que não significa dizer, necessariamente, que o gestor não tenha seguido recomendações do $\mathrm{Cl}$, visto que muitas destas não foram analisadas por não estarem dentro do escopo do estudo.

A falta de análise destas outras recomendações, constantes dos muitos relatórios e memorandos verificados, limitou a pesquisa e poderão ser pontos explorados num próximo trabalho, bem como buscarem-se os motivos pelos quais o $\mathrm{Cl}$ deixou de preocupar-se com os apontamentos reiterados do TCE/RS.

Algumas hipóteses podem ser aqui levantadas, como o fato dos componentes não serem servidores de carreira e exclusivos para as funções da controladoria ou mesmo a diferença entre os métodos e critérios de trabalho utilizados pela auditoria interna e externa. Estas situações podem ter influenciado em algumas das matérias verificadas pela equipe do $\mathrm{Cl}$ ou nos seus resultados, cabendo a um novo estudo estas verificações.

Sugere-se ao $\mathrm{Cl}$ mais atenção com relação aos apontes, para que passe a realizar um acompanhamento das providências adota- 
das pela Administração para saná-los ou que verifique e recomende medidas preventivas para evitá-los. Se nada disso for possível, por decisão da Administração, que justifique porque não serão adotadas estas medidas, como forma de isentar o $\mathrm{Cl}$ de inoperância.

Como sugestão à Administração: que procure apropriar-se do real significado de serviço e servidor públicos, que procure dar condições adequadas ao desempenho das funções exercidas pelo $\mathrm{Cl}$, e trabalhe em consonância com suas recomendações, visto que este órgão é ferramenta importante para evitarem-se extensos, desgastantes e indesejáveis relatórios de apontamentos e os processos advindos destes.

\section{Referências}

BRASIL. Constituição (1998). Constituição da República Federativa do Brasil. Brasília, DF: Palácio do Planalto, sem data. Disponível em: http:// www.planalto.gov.br/ccivil_03/Constituicao/ConstituicaoCompilado.htm. Acesso em: 2 abr. 2014.

BRASIL, Lei no 4.320, de 17 de março de 1964. Estatui Normas Gerais de Direito Financeiro para elaboração e controle dos orçamentos e balanços da União, dos Estados, dos Municípios e do Distrito Federal. Brasília, DF: Palácio do Planalto, sem data. Disponível em: http://www.planalto.gov.br/ ccivil_03/Leis/L4320compilado.htm. Acesso em: 22 fev. 2015.

BRASIL. Lei Complementar no 101, de 4 de maio de 2000. Estabelece normas de finanças públicas voltadas para a responsabilidade na gestão fiscal e dá outras providências. Brasília, DF: Palácio do Planalto, sem data. Disponível em: http://www.planalto.gov.br/ccivil_03/Leis/LCP/Lcp101.htm. Acesso em: 2 de abr. 2014.

GIL, Antonio C. Como Elaborar Projetos de Pesquisa. $4^{\underline{a}}$ ed. São Paulo. Atlas, 2002.

LEITE JUNIOR, Alcides D. Desenvolvimento e mudanças no estado brasileiro. Florianópolis: Departamento de Ciências da Administração/UFSC; [Brasília]: CAPES: UAB, 2009. 90p il.

MILESKY, Helio S. O Controle da Gestão Pública. São Paulo. Revista dos Tribunais, 2003. 
NOVA PETRÓPOLIS. Lei $\mathbf{n} \mathbf{0} \mathbf{3 . 4 6 6}$, de 14 de outubro de 2005. Reorganiza o sistema de controle interno do município de Nova Petrópolis e dá outras providências. Nova Petrópolis, 2005.

NOVA PETRÓPOLIS. Lei $\mathbf{n} \mathbf{0} \mathbf{4 . 0 5 5}$, de 25 de fevereiro de 2011. Altera a Lei Municipal no 3.466/2005, abre crédito especial e dá outras providências. Nova Petrópolis, 2011.

NOVA PETRÓPOLIS. Lei $\mathbf{n} \mathbf{0} \mathbf{4 . 3 1 9}$, de 4 de outubro de 2013. Cria e extingue cargos em comissão constantes do art. 11 da Lei Municipal no 3.598/2006 que estabelece o Plano de Carreira dos Servidores Municipais e suas alterações e dá outras providências. Nova Petrópolis, 2013.

NOVA PETRÓPOLIS. Decreto no 82, de 20 de abril de 2011. Homologa regimento interno. Nova Petrópolis, 2011.

NOVA PETRÓPOLIS. Decreto no 94, de 7 de maio de 2012. Altera o Decreto Municipal no 126/2011 que estabelece normas para aquisição de peças e lubrificantes automotivos dentro do limite de dispensa de licitação prevista no art. 24, II da Lei no 8.666/93. Nova Petrópolis, 2012.

NOVA PETRÓPOLIS. Decreto no 126, de 7 de julho de 2011. Estabelece normas para aquisição de peças e lubrificantes automotivos dentro do limite de dispensa de licitação prevista no art. 24,II da Lei no 8.666/93. Nova Petrópolis, 2011.

NOVA PETRÓPOLIS. Edital de concurso Público no 001/2014, de 17 de janeiro de 2014. Disponível em: http://www.novapetropolis.rs.gov.br/arquivos/001_2014_Concurso_Publico.pdf. Acesso em: 01 mai. 2015.

NOVA PETRÓPOLIS. Edital de concurso Público no 002/2014, de 6 de outubro de 2014. Disponível em: http://www.novapetropolis.rs.gov.br/arquivos/edital_2014_2.pdf. Acesso em: 01 mai. 2015

NOVA PETRÓPOLIS. Memorando no 01 - arquivo do Controle Interno. Nova Petrópolis, 2009.

NOVA PETRÓPOLIS. Memorandos n 05, 09 e 18 - arquivo do Controle Interno. Nova Petrópolis, 2011.

NOVA PETRÓPOLIS. Memorandos no 17, 21, 30, 32, 34 e 36 - arquivo do Controle Interno. Nova Petrópolis, 2012.

NOVA PETRÓPOLIS. Memorandos no 02, 03, 06 e 20 - arquivo do Controle Interno. Nova Petrópolis, 2013. 
NOVA PETRÓPOLIS. Ordem de Serviço sem no - Estabelece valores referentes ao Decreto no 126/2011, de 7 de julho de 2011. Nova Petrópolis, 2011.

NOVA PETRÓPOLIS. Relatório no $\mathbf{0 6}$ - arquivo do Controle Interno. Nova Petrópolis, 2009.

NOVA PETRÓPOLIS. Relatório $\mathbf{n} \mathbf{0} \mathbf{0 3}$ - arquivo do Controle Interno. Nova Petrópolis, 2012.

NOVA PETRÓPOLIS. Relatórios no 05 e $\mathbf{1 1}$ - arquivo do Controle Interno. Nova Petrópolis, 2013.

NOVA PETRÓPOLIS. Relatórios de Verificação no 06, 07, 08, 09, 10, 11, 12, 13 e 14 - arquivo do Controle Interno. Nova Petrópolis, 2011.

NOVA PETRÓPOLIS. Relatórios de Verificação no $03,08,09,10,11,13$, $17,20,22,28,32,36,38,43,53,60,61,64,67$ e 71 - arquivo do Controle Interno. Nova Petrópolis, 2012.

RIO GRANDE DO SUL. Tribunal de Contas do Estado do Rio Grande do Sul. Relatórios de Auditoria Ordinária Tradicional - Acompanhamento de Gestão - Porto Alegre, 2010, 2011, 2012, 2013, 2014.

RIO GRANDE DO SUL. Tribunal de Contas do Estado do Rio Grande do Sul. Relatório de Auditoria Ordinária Tradicional - Acompanhamento de Gestão - Processo no 1010-0200/13-0. Porto Alegre, 2014.

RIO GRANDE DO SUL. Tribunal de Contas do Estado do Rio Grande do Sul. Resolução no 544, de 21 de julho de 2000. Aprova a consolidação e introduz alterações no Regimento Interno do Tribunal de Contas do Estado do Rio Grande do Sul, Porto Alegre, 2000. Disponível em: http://www1.tce. rs.gov.br/aplicprod/f?p=50202:4:2944838324048318::NO::P4_CD_LEGISLACAO:260735. Acesso em: 27 abr. 2015.

RIO GRANDE DO SUL. Tribunal de Contas do Estado do Rio Grande do Sul. Resolução no 936, de 13 de março de 2012. Dispõe sobre as diretrizes a serem observadas na estruturação e funcionamento do sistema de controle interno municipal e dá outras providências. Porto Alegre, sem data. Disponível em: http://www1.tce.rs.gov.br/aplicprod/f?p=50202:4:296351201608975::NO::P4_CD_LEGISLACAO:416969. Acesso em: 30 de mar. 2014.

RIO GRANDE DO SUL. Tribunal de Contas do Estado do Rio Grande do Sul. Resolução no 979, de 22 de maio de 2013. Dispõe sobre os procedimentos a serem adotados pelo Tribunal de Contas do Estado visando à verificação do 
atendimento das exigências relativas à gestão fiscal procedida pela administração pública municipal direta e indireta, contidas na Lei Complementar Federal no 101, de 4 de maio de 2000. Porto Alegre, sem data. Disponível em: http://www1.tce.rs.gov.br/aplicprod/f?p=50202:4:296351201608975::NO::P4_CD_LEGISLACAO:497492. Acesso em: 30 de mar. 2014

RIO GRANDE DO SUL. Tribunal de Contas do Estado do Rio Grande do Sul. Resolução no 1006, de 5 de fevereiro de 2014. Dispõe sobre os critérios a serem observados na apreciação das contas de governo, para fins de emissão de parecer prévio, e no julgamento das contas de gestão dos administradores e demais responsáveis por bens e valores públicos da Administração Direta e Indireta. Porto Alegre, sem data. Disponível em: http://www1. tce.rs.gov.br/aplicprod/f?p=50202:4:296351201608975::NO::P4_CD_LEGISLACAO:565480. Acesso em: 30 de mar. 2014 


\title{
Os Observatórios de Segurança Pública Municipais como Ferramenta de Gestão - o caso do município de Canoas
}

\author{
Claudete de Souza \\ Cristina Carvalho \\ Rosária Lanziotti Moraes
}

Se as últimas décadas mostraram avanços na sedimentação de conquistas sociais, a sua preservação nos últimos tempos não tem sido fácil. A desigualdade na repartição da riqueza, a discriminação, a intolerância às diferenças e à diversidade, a incerteza, a perda dos valores humanistas não são anomalias, mas aspectos constituintes do pensamento globalizado e do sistema econômico capitalista (COSTA, 2005).

Falar em violência é, portanto, atual e desafiante, pois a violência deixou de ser um ato circunstancial para transformar-se numa forma de ver e de estar no mundo contemporâneo. Para tentar explicar sua configuração é importante compreender, primeiramente, as transformações sociais e os fenômenos que a produzem.

O crescimento da ocorrência da violência nos municípios brasileiros, em especial nos centros urbanos, tem exigido respostas mais adequadas do aparato estatal, cujo papel é o de reprimir a violência e exercer controle sobre a ordem social.

No âmbito de uma nova adequação estão as ações orientadas a tratar esta problemática a partir de uma ótica da prevenção capaz de envolver também tratamento específico a questões como o consumo 
juvenil de droga, principalmente o crack, e os furtos e roubos de veículos que provocam na população, a sensação de insegurança.

Este trabalho é resultado de uma pesquisa que procurou evidenciar o uso de novas estratégias que intensificaram as ações de segurança pública nas comunidades com as mais altas taxas de violência e criminalidade no município de Canoas, na Região Metropolitana de Porto Alegre, e que objetivavam produzir resultados de curto e médio prazo que pudessem garantir a segurança da população.

Especificamente a nova estratégia estudada foi a implantação do Observatório de Segurança Pública, procurando demonstrar sua abordagem moderna para o enfrentamento da questão da segurança pública, um direito fundamental, previsto na Constituição Federal de 1988, e de responsabilidade do Estado.

Para cumprir essa responsabilidade o Governo Federal, através do Ministério da Justiça, inaugurou políticas de segurança pública no Brasil, focado na implantação do Sistema Único de Segurança Pública (SUSP) e, posteriormente, na criação do Programa Nacional de Segurança Pública com Cidadania (PRONASCI).

O enfrentamento e prevenção da violência - papel desempenhado pelos estados, em razão de sua obrigação constitucional - é particularmente inovadora e recente, tornando-se imprescindível a estruturação da Administração Municipal para discutir e construir uma identidade institucional para a implementação de uma política de segurança urbana no município. Fortalecer a compreensão do papel da segurança urbana municipal por parte da própria administração municipal e da comunidade inaugura uma nova concepção de segurança pública, cujo propósito é o de promover segurança urbana, preventiva e comunitária, conforme as características de convivência social e local.

Com a nova concepção das políticas públicas de segurança, o foco do Governo Federal é de articular e integrar os órgãos públicos com a sociedade civil, em ações permanentes de promoção de ambientes seguros, como estratégia fundamental de prevenção à violência e à criminalidade, contribuindo para ampliar a qualidade de vida. 
Entretanto, não são poucas as dificuldades e os desafios enfrentados nas cidades, que vão desde o número elevado de ocorrências de violencia que contrasta com os recursos materiais e humanos disponíveis, bem como a falta de informações sistematizadas e dados estatísticos, que proporcionem condições de planejamento e formulação de estratégias para os problemas de maior incidência. A implantação do Gabinete de Gestão Integrada Municipal, criado com o propósito de integrar as forças policiais em todas as esferas de governo, a formulação política dá um passo para a articulação das medidas preventivas e acompanhamento de seu desenvolvimento bem como de um canal de dialogo.

O Observatório de Segurança Pública, objeto desta pesquisa, tem um papel a cumprir na reunião, sistematização e uso da informação sobre a evolução da violência e criminalidade dos municípios, de modo a alimentar essa nova linguagem institucionalmente integrada da política pública de segurança.

Em razão desta convicção, este estudo procurou avaliar o suporte analítico prestado pelo Observatório de Segurança Pública do município de Canoas, no Rio Grande do Sul, para a tomada de decisões nas ações de segurança pública no município de Canoas.

Para lograr este objetivo a pesquisa assumiu um enfoque primeiramente descritivo, ao apresentar a evolução da abordagem da segurança pública nos últimos anos e, na sequencia, evidenciou essa problemática no caso específico do município de Canoas, na região metropolitana de Porto Alegre, no Rio Grande do Sul.

Para atingir os objetivos desta pesquisa, foi realizado um estudo de caso, com enfoque na análise qualitativa dos dados coletados, que consistiram em primeiro lugar em documentos e relatórios do órgão em pauta e, em segundo lugar, nas entrevistas realizadas a gestores do Observatório de Segurança Pública e planejador de política de segurança pública. A leitura exploratória e seletiva dos documentos e das entrevistas permitiu, posteriormente, a análise documental e de texto que enriqueceram as descrições e interpretações. 


\section{1 - Políticas de segurança pública}

A segurança pública é um dever do Estado para com a sociedade que, ainda que credora desse direito, não está isenta, pois também é responsável pela sua consecução, devendo se engajar, a fim de que ela seja alcançada e mantida. Esta questão é de tal maneira relevante que o legislador destinou um capítulo para o assunto na Constituição Federal que, em seu artigo 144 refere:

Art. 144 - A segurança pública, dever do Estado, direito e responsabilidade de todos, é exercida para a preservação da ordem pública e da incolumidade das pessoas e do patrimônio $(\ldots)$

Ao afirmar que a segurança pública é direito mas também responsabilidade de todos, a Constituição Federal, neste artigo específico, inscreve a necessidade da participação cidadã na construção do controle social.

Ainda que fique claro (pela sequencia da redação do artigo) que não só o governo estadual é o responsável, pela segurança pública, Miraglia (2006: 89) enfatiza a necessidade e importância da participação do poder executivo municipal nas políticas de segurança pública:

Ainda que no texto da Constituição Federal Brasileira a responsabilidade pela segurança pública apareça como tarefa a ser compartilhada, sabemos que as políticas públicas na área da segurança foram, historicamente, objeto de ação, sobretudo, dos governos estaduais. Eleger o município como mais um também da percepção das potencialidades da ação do poder local nesse campo de atuação.

Neste contexto, a comunidade e o município se enquadram no que a autora preceitua, pois o estado de insegurança social exige um enfrentamento conjunto entre a comunidade e a administração municipal, de modo a um engajamento para uma melhor abordagem 
da segurança pública no município. É no âmbito da proposta governamental de enfrentamento combinado e compartilhado desta problemática, que é criada uma política pública de segurança, lançada pelo Governo Federal, o Sistema Único de Segurança Pública (SUSP).

\subsection{O Sistema Único de Segurança Pública}

Ao reconhecer a gravidade do problema da segurança pública no Brasil o Governo Federal aproveitou para inaugurar uma nova etapa na história da segurança pública brasileira, com o foco da ação situado na implantação do Sistema Único de Segurança Pública (SUSP).

Orientado pela perspectiva de elaborar uma política pública de segurança unificada, de âmbito nacional, objetivando ampliar a integração e articulação de forma prática, das ações das polícias federais, estaduais e municipais, preservando assim, a autonomia das instituições envolvidas, o Governo Federal lançou, em abril de 2003, o SUSP.

Com a implantação do programa de Segurança Pública para o Brasil, o Governo Federal, através da Secretaria Nacional de Segurança Pública (SENASP), propôs eixos estratégicos entre os quais tem destaque a educação como instrumento fundamental para a efetivação das referidas mudanças nas polícias brasileiras. Para o referido programa é por meio da educação que o país poderá construir uma nova concepção de abordagem da segurança pública, que consiste na prevenção como forma inovadora.

A implantação do SUSP é, para o Governo Federal, a possibilidade da consolidação da democracia do sistema político brasileiro, se ela vier acompanhada da implantação de uma concepção de segurança cidadã, com a participação da sociedade.

\subsection{O Programa Nacional de Segurança Pública com Cidadania}

Segundo o Ministério da Justiça o Programa Nacional de Segurança Pública com Cidadania (PRONASCI), lançado em 2007, tem como propósito a prevenção mas, também, o controle e a repressão 
à criminalidade e, para isso, propõe articular as ações de segurança pública com as políticas sociais. Para isso, o PRONASCI pretende fomentar a integração entre União, estados e municípios através das diretrizes do Sistema Único de Segurança Pública (SUSP).

O PRONASCI foi instituído pela Lei Federal no. 11.530, de 24 de outubro de 2007, como um novo paradigma de segurança pública, pautado em duas grandes inovações:

Articulação entre ações de segurança e ações de natureza sociais e preventivas, atuando nas raízes socioculturais da violência e da criminalidade, por meio do fortalecimento dos laços comunitários e das parcerias com as famílias, sem abdicar das estratégias de ordenamento social e repressão qualificada;

Fomento de uma agenda federativa compartilhada, com o envolvimento de todos os entes, acrescentando, ao papel basilar dos estados, o Governo Federal, com indução de políticas e financiamento, e os municípios, com papel ativo nas ações de prevenção.

Esta inovação foi traduzida na promoção de um plano de inclusão e fortalecimento da coesão social, através do empoderamento segundo o educador Paulo Freire, a capacidade do indivíduo realizar, por si mesmo, as mudanças necessárias para evoluir e se fortalecer - das relações entre profissionais de segurança pública e sociedade civil, e do ingresso a um Estado qualificado.

Fica claro deste modo que este programa foi instituído com o objetivo de garantir os direitos dos cidadãos pautados na Constituição Federal e buscando, através de iniciativas pioneiras, a solução de problemas vivenciados na sociedade, ultrapassando os sistemas existentes de políticas de segurança pública, otimizando soluções por meio de ações conjuntas dos três entes federativos.

Nesta nova perspectiva os municípios devem desempenhar fundamental um papel ativo na construção de políticas públicas modernas para enfrentar os desafios no campo da segurança pública. 
Abordam-se no tópico seguinte, os fundamentos da atuação municipal no campo da segurança pública de forma inovadora, pois, o município tem a percepção das potencialidades da ação do poder local nesse campo de atuação.

\section{2 - A segurança pública no espaço municipal}

A atuação dos municípios na área da gestão de políticas públicas de segurança contribui para a redução do nível da violência e criminalidade nos centros urbanos. Para isso contribuem a implementação de políticas integradas de segurança pública no âmbito municipal, e a execução de programas de prevenção e controle da violência que geram oportunidades para a população jovem. Estas ações tendem a diminuir os fatores de risco para a violência e melhorar a qualidade de vida da população, tendo em vista a proteção dos seus direitos civis.

Igualmente buscam fortalecer a capacidade institucional e organizativa do poder público municipal, no que diz respeito à elaboração e implementação de uma política de combate à violência e à criminalidade no âmbito local, integrada às demais políticas públicas municipais, representa uma conquista democrática. Ao mesmo tempo constitui um novo desafio, ao fortalecer os espaços de controle social da sociedade sobre o poder público, particularmente no tocante às ações relacionadas à segurança pública.

Por outro lado também buscam instituir programas de prevenção e controle do crime com base na prevenção situacional, com foco nos territórios identificados, consubstanciados em parâmetros científicos e, igualmente fortalecer as instituições de segurança pública local. Visam igualmente aumentar a eficiência e a eficácia na identificação, perseguição e prevenção do delito através de melhor coleta, sistematização e análise da informação. Desta forma buscam contribuir para a gestão do conhecimento por parte de gestores e técnicos no âmbito da segurança cidadã.

Sabe-se que no Brasil a responsabilidade pela segurança pública é predominantemente dos governos estaduais, através da atuação 
das polícias civil e militar, bem como do Poder Judiciário dos estados, Ministério Público e do sistema prisional, todos estruturados e gerenciados no âmbito estadual. Em concomitância, o relatório de pesquisa apresentado por Azevedo (2007) relata que há um aumento no sentimento de insegurança, causado pelo crescimento da violência e da criminalidade. Este paralelismo está associado às dificuldades dos governos federal e estaduais para atenderem às demandas de segurança da população. Assim, outras formas de combater e prevenir as violências são adotadas.

Diante desta problemática, Azevedo (2007, p.11) aponta o empenho dos governos municipais e da sociedade civil em pensar políticas públicas locais de prevenção e controle da violência.

A atuação dos governos municipais na área de segurança pública parte da demanda social por segurança, que solicita ações imediatas no combate à violência e à criminalidade e não diferencia a responsabilidade dos diferentes níveis de governo. É nos municípios que ocorrem situações/eventos envolvendo os cidadãos e, também, nesse âmbito que os governos têm contato mais próximo com a população. Neste contexto, pode-se pensar no município como um novo ator na área de segurança pública, principalmente em ações de prevenção da violência e criminalidade.

Cabe destacar a importância do empenho dos municípios em abordar esta sensação de insegurança vivida pela população, bem como privilegiar a participação da comunidade. Cabe ao município contribuir das mais variadas formas, como por exemplo, na melhoria da iluminação das vias públicas, das praças, adequações das vilas irregulares, terrenos baldios, entre outras intervenções, integrando os serviços das diversas secretarias.

Partindo da análise de Azevedo (2007), é possível refletir e averiguar a imprescindibilidade da Administração Pública em empenhar-se no fortalecimento dos Gabinetes de Gestão Integrada, para apoiarse em uma gestão integrada com os demais órgãos de segurança pública. 


\subsection{Gabinetes de Gestão Integrada}

De acordo com a SENASP, órgão responsável pela promoção de políticas de segurança pública, os Gabinetes de Gestão Integrada surgiram no contexto do SUSP:

O GGI é um fórum executivo e deliberativo, que tem como missão integrar sistemicamente os órgãos e instituições federais, estaduais e municipais, priorizando o planejamento e a execução de ações integradas de prevenção e enfrentamento da violência e criminalidade. Visa, ainda, avançar em torno de um paradigma em segurança pública com enfoque em boas práticas de gestão por resultados (SOARES, 2009, p.12).

Para estruturar os Gabinetes, as diretrizes aprovadas pelo PRO$\mathrm{NASCI}$ formatam o seguinte desenho:

Criar, estruturar, implantar, compor, e fortalecer, democraticamente, Gabinetes de Gestão Integrada nos três níveis de governo, para: promover a atuação conjunta e coordenada dos organismos de segurança pública, com entidades públicas e privadas, respeitando e acatando as diretrizes e deliberações dos conselhos de segurança pública (SOARES, 2009, p.342).

As instituições, responsáveis pela segurança pública, necessitam de sistemas integrados e inteligentes focados na melhoria dos serviços prestados à sociedade. Conforme relatado na Coletânea Nacional, não há possibilidade de construir um sistema de segurança pública eficiente sem compartilhar os conhecimentos e sem a cooperação entre as instituições. Os Gabinetes de Gestão Integrados (GGI) são espaços que congregam instituições diferentes em torno de um objetivo modernizante de atenção à segurança pública.

Destaca-se este trecho da Coletânea dos GGls: 
Parafraseando o gênio Albert Einstein: "Não há nada mais insano do que fazer todos os dias as mesmas coisas e esperar resultados diferentes". Lamentavelmente, o paradigma da segurança pública dos últimos 40 anos foi pautado por fazer mais do mesmo, além da fragmentação e reatividade das instituições, sem muita antecipação e planejamento e pouca visão preventiva (SOARES, 2009, p.12).

De acordo com o Programa Nacional, os GGIs foram planejados para constituir uma rede nacional, nos níveis regional, estadual e municipal. Sua proposta consiste em trabalhar com uma dinâmica funcional heterogênea. Para que este novo modelo de funcionamento no campo da segurança pública tenha êxito, forma-se um consenso acerca da importância da transformação cultural por meio de um processo de adaptação e muita tolerância, para que as novas ideias sejam "libertadas" do antigo senso comum, que conduziu estas políticas nada eficazes nas ultimas décadas.

Na sequencia cabe-nos discutir o papel e a atuação dos Observatórios de Segurança Pública e a contribuição que, por meio de coleta e análise de dados, pode assinalar situações problemáticas a serem enfrentadas pelos Gabinetes de Gestão Integrada-Municipal (GGI-M).

\subsection{O Observatório de Segurança Pública}

O Observatório de Segurança Pública foi criado para coletar e realizar análises sobre a violência e a criminalidade, bem como monitorar as ações realizadas no município. Destaca-se a relevância dos Observatórios na gestão do conhecimento para a consecução das ações integradas de segurança pública, na gestão da comunicação, da formação e da mobilização, e na gestão das ações de prevenção.

De acordo com o propósito do Ministério da Justiça, idealizador desta nova abordagem de política pública, o Observatório de Segurança Pública faz parte da estrutura do GGI-M e é o órgão responsável pela gestão do conhecimento, em produzir e sistematizar as informações através de estudos e análises científicas. Seu desempenho 
possibilita descobrir a melhor forma de enfrentar os problemas de segurança pública do município.

O objetivo do Observatório de Segurança Pública é, portanto, trabaIhar a informação de modo a que ela se torne a principal ferramenta para planejar as ações de repressão no GGI-M, e viabilizar um sistema de inteligência que poderá auxiliar na tomada de decisões, tanto para a constituição de diagnósticos quanto para a identificação de demandas locais.

Em virtude do exposto, salienta-se a importância destes estudos, pois, eles poderiam possibilitar um diagnóstico capaz de contemplar a realidade de cada comunidade, identificando o perfil das ações de violência e os fenômenos relacionados à criminalidade local, e verificar a percepção dos munícipes em relação à segurança pública, o que deve contribuir para a tomada de decisão das ações a serem implantadas.

\section{3 - O caso do Observatório de Segurança Pública de Canoas - RS}

No município de Canoas, o Observatório de Segurança Pública foi implantado inicialmente com recursos captados do Governo Federal. O município justificou a criação, estruturação e implementação do Observatório de Segurança Pública, defendendo a importância de produzir e analisar dados relativos à caracterização da natureza, do número e da distribuição espacial da ocorrência das ações de violência e dos crimes incidentes no município. Foi assim instituído um Centro de Pesquisa Social Aplicada à Segurança Pública.

Com este propósito e esta justificativa foi institucionalizado e tornou-se uma política pública, através da Lei Municipal n. ${ }^{\circ}$ 5.386, de 19 de maio de 2009. Seus objetivos passavam também pela qualificação e aperfeiçoamento da gestão de segurança pública, através das atividades desenvolvidas pelo GGI-M e, também, por oportunizar novas possibilidades de abordar e intervir na gestão de políticas públicas de segurança, com foco na prevenção da violência.

Com o propósito de garantir a sustentabilidade do projeto, o município instituiu uma parceria com a Fundação La Salle e sua fa- 
culdade local, a Unilasalle, a fim de constituir um grupo de pesquisa acadêmico. O Fórum Brasileiro de Segurança Pública, a partir do papel desempenhado no I Colóquio sobre Gestão do Conhecimento da Segurança Pública de Canoas, firmou-se como um outro parceiro ao nível da cooperação técnica com o Observatório de Segurança Pública de Canoas.

O Observatório de Segurança Pública de Canoas é considerado um centro de pesquisa social aplicada e está sediado na Secretaria Municipal de Segurança Pública e Cidadania de Canoas. Desde sua implantação o Observatório foi formado por um tripé composto pela Prefeitura Municipal de Canoas, o Fórum Brasileiro de Segurança Pública e o Grupo de Pesquisa e Violência e Cidadania da Universidade Federal do Rio Grande do Sul.

A gestão do conhecimento, através do Observatório, é de responsabilidade do poder Executivo que deve prover os meios e os recursos humanos necessários para o funcionamento adequado do Observatório de Segurança Pública.

Foi também constituído um Conselho de Avaliação Externa do Observatório, com o objetivo de avaliar a implementação das políticas de segurança desenvolvidas no Município, a partir dos dados elaborados pelo Observatório. O Conselho de Avaliação Externa do Observatório será formado por até 10 (dez) pessoas com notório saber científico na área de segurança pública.

Deste o início das atividades sua principal diretriz é analisar e construir dados e indicadores capazes de embasar as políticas públicas de segurança construídas no município, através de informações aprofundadas dos agenciamentos, natureza e incidência das violências e dos eventos não criminais. O Observatório cumpre com uma missão fundamental na gestão do conhecimento da política municipal de segurança pública, voltado para a qualificação, formulação, execução e especialmente a avaliação das políticas públicas de segurança desenvolvidas no município.

Para Pazinato (2013) o GGI pode contribuir para romper a lógica da "gestão pública por espasmos", redefinindo o padrão organizacio- 
nal das corporações de segurança pública e justiça criminal, ou seja, o GGI-M trabalha como um órgão articulador, não medindo esforços para integrar as instituições de segurança pública, para que estas trabalhem integradas de forma qualificada, aumentando a força e potencializando as ações.

Pazinato da Cunha, Kerber e Dal Santo (2013) ressaltam que muitas vezes, as políticas públicas são planejadas de acordo com a necessidade emergente, pelo clamor da sociedade e os diagnósticos são deixados de lado. Destacam ainda que,

Por essa razão, o Observatório de Canoas, através da realização de estudos e pesquisas de fontes primárias e secundárias, vem buscando sensibilizar os gestores públicos municipais, estaduais e federais que participam do GGI-M acerca da relevância, político-institucional, da sistematização e análise dos dados, informações e conhecimentos produzidos pelas instituições de segurança pública e justiça criminal e mesmo das instâncias de participação popular. (PAZINATO DA CUNHA, KERBER e DAL SANTO, 2013, p.81).

Para os envolvidos no Observatório de Canoas, o objetivo da existência do órgão reside, principalmente, no fortalecimento da capacidade do município em planejar políticas públicas de segurança,

tudo o que é feito é para garantir que o secretário municipal, o GGI-M tenham um diagnóstico atualizado, fiel e caracterize alguma realidade empírica com informação criada criteriosamente, que vai municiar tanto o GGI-M, o Secretário de Segurança, a Gestão Municipal como um todo, a tomar as decisões com base nessas informações (Entrevista concedida por um gestor do Observatório).

Para estes gestores, de modo geral, o Observatório "está cumprindo com o objetivo que é de fortalecer a capacidade do município em intervir na segurança pública". Eles ressaltaram também que estão em um momento de reavaliar a atuação dos projetos, trocando eventualmente de modelos de gestão. Em uma das entrevistas foi 
destacado que "fala-se muito hoje em trabalhar com a prevenção terciária, que é trabalhar com egressos do sistema prisional", mas que, em Canoas, pela análise dos dados feita, 54\% das mortes violentas ocorridas na cidade entre janeiro de 2014 e março de 2015 foram vítimas de egressos do sistema prisional.

Assim o respondente destaca que

baseado nesta pesquisa justifica-se a necessidade de planejar projetos ou que se orientem ações voltadas para manter os egressos vivos, incluídos na sociedade. Este é um diagnóstico novo, que será repassado à secretaria de segurança que fará a gestão deste dado, que apoiará na tomada de decisão, que possivelmente desencadeará um processo, a partir da informação que o Observatório construiu fazendo pesquisa, e não por opinião de ninguém. Havia como hipótese que seria em torno de $20 \%$ a $30 \%$, mas o resultado foi $54 \%$. Do total das vítimas egressas do sistema prisional, 77\% deles morreram em até 2 anos e a média de tempo de vida é de 7,5 meses da saída do sistema prisional até à morte (Entrevista concedida por um gestor do Observatório).

Esta declaração demonstra a urgência de planejar as ações a serem implementadas, os projetos a serem desenhados conceitualmente e operacionalmente para pôr em prática alguma ação municipal mais eficaz.

O Observatório mantém atualizados os diagnósticos com as estatísticas criminais e não criminais e, salientou um entrevistado, gestor do Observatório, que

desde o início das atividades é realizada a coleta de três indicadores: roubo de veículos, furtos de veículos e homicídios. Homicídios o Observatório amplia metodologicamente para mortes violentas por causas externas intencionais, para que se tenha sempre um quadro claro da violência letal no município, se trabalha com homicídio, latrocínio e encontro de cadáver com sinais de execução, morte em confronto com a polícia. Evidencia-se na série histórica que o latrocínio não é a principal causa de motes em Canoas (Entrevista concedida por um gestor do Observatório). 
A partir deste levantamento, é apresentado ao GGI-M, órgão deliberativo articulador que realiza o planejamento das ações.

Para outro respondente, responsável pelo planejamento das ações e das políticas públicas de segurança,

a ideia é planejar sempre apoiado no diagnóstico apresentado e não de experiências vivenciadas pelos profissionais de segurança pública. Na apresentação do diagnóstico, o responsável pelo Observatório apresenta a metodologia que foi utilizada para a coleta de dados, no esforço de que o método científico da pesquisa acadêmica ou pesquisa social aplicada é explicado a metodologia, porque a princípio se repetirem os mesmos passos, se chegará nos mesmos resultados (Entrevista concedida por um planejador de política de segurança).

Para o gestor do Observatório, a gestão da informação procura avaliar e monitorar as políticas públicas, observando se há mudança no cenário, e alterando o contexto desenhado sempre que necessário, realizando correções. Ao dar exemplos, afirma que os primeiros diagnósticos feitos em 2009 hoje já não são válidos. A realidade mudou. Na época, afirmava ele, foi desenhada uma política de segurança que partia da inclusão com os projetos sociais, do uso das câmaras de vigilância para dar suporte à inteligência e, a integração era feita a partir do GGI-M. Mas, com base precisamente no sistema de inteligência e nos mapas que o Observatório produz, foi possível promover ajustes e adequações às mudanças acontecidas e, assim, readequar os mapas conceituais dos projetos.

Nos relatos dos gestores "os dados chegam ao Observatório, por coleta realizada no banco de dados da Polícia Civil e da Brigada Militar" o que é um fato incomum no Brasil. Mas, no município de Canoas, identificamos a existência de um convênio entre o estado e o município, para que exista esta articulação. Muitas ocorrências são falhas, algumas são duplicadas, outras não atualizadas, muitas subnotificações. "É um esforço trabalhar com as ocorrências, pela falta de informações". O convênio prevê uma senha de acesso às 
consultas integradas, a que os técnicos do Observatório têm acesso. Estes deslocam-se até à Secretaria Estadual, no Departamento de Geografia e Estatística do Estado e fazem a pesquisa. "Essa pesquisa é muito manual, porque o sistema de consultas integradas é antigo e quando ele foi pensado, não foi planejado em caráter de gestão, era mais como receptor de dados".

Para este entrevistado, gestor do Observatório, "o sistema não contempla um espaço para que se possa selecionar e ver os crimes por perfis (homens, mulheres, idade, etc) não existe esta função como opção quando o software não é de gestão". Destacou que "estes softwares de gestão são mais recentes". Sendo assim, é construído um banco de dados, copiando todas as informações (data, hora, local do fato, tipo). Enfim cada informação é copiada e incluída no software de gestão, para serem trabalhadas e analisadas. Os dados são coletados de acordo com a estrutura do Observatório. A coleta normalmente ocorre por quinzena. Ressaltou ainda que há, além do convênio com o estado, uma parceria com o sistema de inteligência do estado. Não obstante, os entrevistados alertaram que o estado não consegue fornecer dados mensais mas, apenas trimestrais, que são coletados pelo Observatório em todas as delegacias do município.

É realizado o georeferenciamento de 95\% das ocorrências, além do local, outras informações da ocorrência como perfil da vítima, quem era, idade, etnia, onde morava, onde morreu, bairro de residência, bairro da ocorrência, se tinha antecedentes criminais, que antecedentes, foi-se afinando os dados, e cercando este ponto georeferenciado de informações, que é sempre um trabalho relacional, na medida em que a gestão vai demandando. Foi diagnosticado que o perfil das vítimas se assemelha com o perfil dos autores. A maioria das vítimas e autores são moradores de Canoas, residentes em bairros mais periféricos e são adultos jovens, ambos possuem antecedentes criminais. A grande maioria entrou no sistema prisional/carcerário pela prisão em flagrante e não por condenação (Entrevista concedida por um gestor do Observatório). 


\subsection{O Observatório na gestão da segurança pública no município de Canoas}

A gestão do conhecimento é apoiada nas ações do Observatório de Segurança Pública, como instância de suporte do GGI-M. A eficiência da integralização das estratégias de prevenção nas diferentes secretarias só tem impacto com o funcionamento eficiente deste Observatório. A taxa dos homicídios na cidade, que tem patamares elevados, só pode ser abordada com prevenção e controle de forma adequada, por meio de ação integrada (com participação efetiva das Polícias) de coleta, sistematização e análise da informação sobre mortes violentas e sobre a dinâmica da criminalidade no município. Nessa direção, o trabalho do Observatório prevê a integração dos diferentes sistemas de informação existentes na gestão municipal, de forma a produzir análises sistemáticas para subsidiar as ações e permitir o seu monitoramento contínuo.

O Observatório de Segurança Pública recebe as ocorrências de homicídios, através dos Boletins de ocorrência (BOs) fornecidos pela Polícia Civil e de dados fornecidos do Sistema de Informações sobre Mortalidade (SIM), da Secretaria Municipal de Saúde, sistematiza-os e elabora uma análise. O GGI-M monitora estas ocorrências desde 2009, discute seus agenciamentos, sua espacialização e define estratégias de controle e redução.

Conforme relatado por Pazinato (2013), os dados coletados geram registros para responder a questões específicas atendidas, "as informações nem sempre coincidem entre si, fato que nos permite complementá-las e melhorar sua qualidade". Sendo assim, o termo "homicídio" merece ser interpretado de forma mais genérica, considerado crimes violentos com resultado de morte. O termo homicídio é descrito nas tipificações policiais que compõem esse conjunto de crimes, que são encontro de cadáver e latrocínios, principalmente. Esta terminologia foi empregada também, em pesquisa encomendada pela Secretaria Municipal de Segurança Pública e Cidadania de Canoas (ROLIM, 2009). 
Para os autores, a utilização desta metodologia traz vantagens e desvantagens para o gestor na definição das políticas públicas de segurança de prevenção às violências e criminalidade, bem como nas ações referentes aos crimes mais violentos contra vida.

A vantagem reside na possibilidade de se compreender os eventos de um modo mais próximo da "realidade", ou seja, agregando-se eventos inicialmente distintos, que produzem, todavia, reações sociais similares. Por outro lado, a tipificação legal, as motivações e os agenciamentos para a prática desses crimes não são as mesmas. Uma desvantagem significativa é a falta de comparabilidade com outros municípios da região e do país, uma vez que há divergência na metodologia utilizada (Dal Santo; Kerber, 2010).

Ressalta-se, em concordância com os autores, a importância da participação de todos os municípios nesta nova concepção de segurança pública, que permitiria a realização de estudos comparativos e quiçá, do planejamento de ações integradas por regiões.

Foi realizado também um acompanhamento de outros crimes, aqueles que geram a sensação de insegurança na população.

O GGI-M de Canoas também passou a acompanhar mensalmente as ocorrências de furto e roubo de veículos, principalmente por se tratarem de crimes que potencializam o sentimento de insegurança da população e por estarem, eventualmente, relacionados a uma ampla rede de atividades criminosas. A principal dificuldade encontrada pelo Observatório para trabaIhar essas informações deve-se à qualidade do preenchimento dos BOs, especialmente no campo referente à localização dos eventos, prejudicando, potencialmente, a espacialização, através do georreferenciamento desses delitos.

Pela experiência na aplicação de estatísticas de crimes, mesmo com poucos dados analisados, o GGI-M, observou que é necessário melhorar a qualidade das informações. Melhoria no processo de registro, coleta, análise e a forma de disponibilizar essas informações para 
os gestores públicos de segurança. Destaca-se a importância de apurar as informações coletadas, renovando os métodos e técnicas de análise.

A qualificação reverte em esforços causados para a melhoria no banco de dados do Observatório, incluindo informações estruturadas sobre, por exemplo, o meio empregado pelos autores e outros elementos que configuram o modo de operação dos delitos registrados.

Para o entrevistado planejador de política de segurança, as ações produzidas pelo órgão contribuem para o planejamento e avaliação do Plantão Integrado de Fiscalização, ação integrada realizada pelo GGIM de Canoas objetivando fiscalizações administrativas e policiais, em busca da diminuição da perturbação do sossego e a redução de outros índices de criminalidade. A esse respeito vale referir:

Os locais visitados pelos Plantões Integrados de Fiscalização são definidos a partir da sistematização das reivindicações e das denúncias da cidadania canoense, registradas nas diversas instâncias que conformam o Sistema de Participação Popular Municipal, das informações repassadas pela Coordenadoria de Atendimento ao Cidadão, daquelas fornecidas diretamente pelos órgãos de fiscalização do município, da Sala Integrada de Monitoramento e, ainda, da Brigada Militar, por meio do número 190. Essas informações, estruturadas em um banco de dados, permitem o planejamento das ações, as quais, por sua vez, são registradas em um instrumento próprio, e espacializadas, o que possibilita a sistematização e a análise das atividades realizadas pelo Plantão, assim como das ações específicas de cada órgão envolvido nesta atividade (Pazinato (2013) apud, Prandini; Bergonci, 2013).

Em virtude do exposto, pode-se observar que as ações são planejadas apoiadas por um banco de dados estruturado, com informações de vários órgãos que são fundamentais para o aprimoramento da gestão da segurança pública, possibilitando a sistematização e análises das atividades realizadas pelo plantão integrado.

Destarte, a sistematização e as ações espacializadas, que ocorrem no local em que há a denúncia do problema, aumentam as chan- 
ces de obter-se sucesso nas operações integradas, possibilitando uma Gestão de Segurança Pública eficiente e eficaz, e proporcionando resultados positivos em relação ao serviço público prestado, cuja principal finalidade é atender as demandas da sociedade.

Ao ser inquirido acerca da capacidade do Observatório de Segurança Pública funcionar efetivamente como ferramenta de gestão, o gestor entrevistado destacou que o Observatório

Nasceu quase que puramente para ser uma ferramenta de gestão, porque considero como gestão e gerenciamento de risco também, pois, se mapeia os riscos e se questiona porque destes diagnósticos, fugindo um pouco da área criminal e debater com a Secretaria porquê deste resultado (Entrevista concedida por um gestor do Observatório).

A política de segurança prevê que se realize esforço na repressão qualificada e na prevenção. Então, enquanto ferramenta de gestão do GGI-M, o Observatório se propõe fortalecer tanto a repressão qualificada com planejamento, e que os projetos de inclusão e prevenção partam de um diagnóstico fiel e não por hipóteses.

Pode-se evidenciar pelos respondentes que, grande parte da atuação do GGI-M é orientada pelos resultados produzidos pelo Observatório, que geram, sempre, satisfação nos plenários dos fóruns de segurança. Como exemplo de ações pode-se citar:

- Os plantões integrados de fiscalização: têm como objetivo intensificar as fiscalizações administrativas por parte do município, visando ao estímulo à convivência cidadã, à diminuição da perturbação do sossego, à redução dos índices de criminalidade e ao aumento da sensação de segurança pública no município;

- As Câmaras Técnicas (CT): espaços permanentes de discussão acerca de assuntos relevantes na seara da segurança pública abrangidos pelo GGI. São elas: CT Fiscalização (tem como foco a elaboração e execução de todos os tipos de ações que 
exigem a intervenção do município no que diz respeito à inspeção, verificação, averiguação e medidas administrativas de Fiscalização Municipal), CT Policial (tem como objetivo a organização e troca de informações visando operações direcionadas e especificas da área policial) e CT Prevenção e Recuperação em demandas de Drogas lícitas (tem como objetivo articular, integrar e potencializar serviços existentes, dentre eles o Programa Crack é Possível Vencer, para o tratamento e encaminhamento de usuários de drogas);

- As Câmaras Temáticas (CT): se configuram espaços temporários de escuta popular e de interlocução entre o GGl e a sociedade civil. São elas: CT Eventos (tem como objetivo tratar das medidas de segurança e fiscalizações dos eventos do município), CT Protocolo de Ocupação e demais temas (tem como foco prevenir e coibir a ocupação irregular de áreas no território municipal de Canoas durante feriados prolongados).

O responsável pelo planejamento das ações e das políticas públicas de segurança destacou, em dado momento, que o GGI-M leva a cabo todas as ações, baseadas no diagnóstico do Observatório. Ressaltou também que o Observatório de Segurança Pública fornece suporte analítico para a tomada de decisão nas ações de segurança pública no município, "As decisões são técnicas, tomadas, apoiadas pelo diagnóstico do Observatório, e que é essencial ter o GGI-M e o Observatório estruturado e ressalta ainda a importância do Conselho Municipal de Segurança pública, com a participação da comunidade".

Ambos os respondentes apontaram o Observatório de Segurança Pública como uma ferramenta de gestão para a segurança pública por nortear o trabalho realizado por todos os órgãos da segurança, por fornecer dados, diagnósticos, informações. Destacaram ainda que a atuação do Observatório é fundamental para que as ações sejam planejadas e realizadas de acordo com o estudo apontado nas pesquisas.

Para Pazinato $(2013$, p.89) há que: 
Os GGls aparecem, nesse escopo, como uma ferramenta essencial para desfazer essas amarras burocráticas paralisantes e que vão de encontro a atual política nacional de segurança que estabelece as bases para a construção de um "novo paradigma de segurança com cidadania", centrados na construção de alternativas democráticas e dialógicas para a mediação dos conflitos, buscando superar a lógica tradicionalmente repressiva e reativa do funcionamento das instituições e órgãos que compõem o controle social formal.

Consoante essa política, a experiência do Observatório de Segurança Pública de Canoas aparece como uma expressão do entrelaçamento da pesquisa científica/acadêmica com a pesquisa realizada na e para a própria gestão pública. Esse "tipo" de pesquisa desvela-se como essencial para as decisões dos gestores públicos municipais no âmbito do GGl, especialmente no processo de consolidação das políticas públicas que se pretendem não somente de governo, mas também de estado.

O Observatório foi constituído como um centro de pesquisas aplicadas à gestão do conhecimento, para fortalecer a capacidade do município em planejar políticas públicas de segurança, sendo ele considerado uma ferramenta de gestão, impulsionando e monitorando as ações.

$\mathrm{Na}$ pesquisa realizada, foi possível identificar dificuldades em tornar as metodologias e as estatísticas criminais padronizadas, com vistas a ampliar o conhecimento na área da segurança pública, permitindo um mínimo de comparabilidade regional, por não haver integração em todos os âmbitos de governo.

Pazinato $(2013$, p.90) ressalta que:

Na construção do Observatório, inúmeras foram as complexidades, conforme se afirmou de construção das metodologias e das escolhas que se teve que fazer. Acredita-se que a experimentação, a criatividade e a ousadia foram, talvez, o segredo para que se pudesse criar, num "campo em branco", tantas pesquisas e forjadas as bases de um sistemas de informação na área da segurança pública no plano local. 
Pelos diagnósticos efetuados por esta abordagem inteligente e planejada da segurança pública no município, pode ser destacado o dado evidenciado do elevado número de homicídios praticados por egressos do sistema prisional, para pensar em que ações deverão ser implantadas, a fim de mantê-los vivos e incluí-los novamente na sociedade. Para além deste, foi também revelado que o alto índice de roubos e furtos de veículos é o maior responsável pela sensação de insegurança local.

Atualmente o Observatório de Segurança Pública pesquisa e analisa dados nos três eixos, homicídios, furtos e roubos de veículos e, há que destacar que o delegado de furtos e roubos qualificados do município de Canoas, começou a utilizar os mapas do Observatório para fundamentar os inquéritos que são enviados sistema ao judiciário, o que corrobora a tese defendida nesta pesquisa de que a efetividade no resultado nas ações de segurança pública dependem da integração entre os órgãos.

\section{Considerações finais}

Foi possível observar nesta pesquisa, que no município de Canoas, os órgãos de segurança pública trabalham de forma integrada, apoiando-se nos diagnósticos realizados pelo Observatório de Segurança Pública e planejando ações conjuntas, de forma a minimizar os problemas encontrados.

Com a definição de novas políticas públicas de segurança, como a implantação do Sistema Unificado de Segurança Pública, a população almeja um futuro melhor no que diz respeito à segurança pública. Esta política prevê melhorias nas ações com foco maior na prevenção. Por outro lado, esta também é uma condição para a consolidação da democratização do sistema político brasileiro e a implantação de uma segurança cidadã, onde as pessoas possam ter a garantia plena e seus direitos, por meio de mecanismos institucionais eficientes e eficazes, capazes de prever, prevenir, planejar, solucionar pacificamente e controlar as ameaças e as violências. 
O PRONASCI, instituído pela SENASP, reconhecido como um programa de destaque na política de segurança pública, capaz de trazer inovações e mudança de paradigma da segurança pública, ao investir em ações de envolvimento da comunidade no combate à criminalidade. O Programa inovou na implementação de diversas ações e potencializou o Sistema Único de Segurança Pública e também nas três esferas de governo, incentivando os municípios a contribuírem com a segurança pública em especial na prevenção.

A implantação dos Gabinetes de Gestão Integrada constitui uma etapa fundamental no processo da gestão das ações e políticas de segurança pública de forma integrada, objetivando alcançar resultados efetivos sobre o problema da segurança pública no Brasil.

Neste trabalho foi analisado como o Observatório de Segurança Pública contribui como uma ferramenta importante para a gestão do conhecimento, fortalecendo a capacidade do GGI-M, de seus gestores para tomar decisões para o planejamento de ações, baseados nos diagnósticos realizados, através de pesquisas e levantamentos.

A integração dos órgãos de segurança e demais atores envolvidos potencializa as ações realizadas, obtendo resultado com maior eficiência, pois com os responsáveis pelo problema da segurança pública reunidos, atuando de forma integrada, cada um dentro da sua especialidade e vocação, de forma conjunta e coordenada para a solução dos problemas.

O nosso objetivo consistiu em verificar se o Observatório de Segurança Pública desenvolvia condições e ações para fornecer o suporte analítico para a tomada de decisão nas ações de segurança pública no município de Canoas. Para isso foram realizadas entrevistas que, no entanto, poderão ter apresentado alguma parcialidade - apesar dos cuidados tomados - por serem prestadas por indivíduos comprometidos com o resultado de seus trabalhos.

De qualquer modo foi percebido o esforço para a superação da lógica de ação por espasmos, na gestão pública. Deste modo se busca romper com as formas tradicionais de gestão e focar num modelo novo na segurança pública municipal, no qual as informações, os dados, os diagnósticos são levados em consideração e, até mesmo, 
considerados imprescindíveis para nortear as políticas públicas municipais e planejar as ações de segurança.

Diante do exposto pode-se afirmar que a grande contribuição do Observatório de Segurança Pública do município de Canoas é o suporte oferecido na tomada de decisão dos gestores públicos municipais, por meio da produção, sistematização, análise e divulgação das informações, e do conhecimento gerado no campo da segurança pública.

A integração entre os órgãos, proporcionado pelo GGI-M, inovou no processo de gestão. Se tradicionalmente cada órgão público faz o seu diagnóstico particular sobre o problema e busca resolver de forma isolada o problema, esta integração contribuiu para estruturar trabalhos em equipe, ao incentivar a participação, para que todos se sintam parte de um esforço coletivo na busca de soluções no campo da segurança pública.

Cabe destacar que a tarefa de integrar não exige grande esforço financeiro, mas sim a busca de sensibilização e comprometimento dos atores envolvidos responsáveis pela gestão das políticas pública de segurança.

Conclui-se, após analisar os dados coletados, e comparando com a revisão da literatura, que se confirma a hipótese desta pesquisa. A contribuição dos municípios na segurança pública é programar os Gabinetes de Gestão Integrada-Municipal, GGI-M e os Observatórios de Segurança Municipal para fomentar as políticas de segurança e dar suporte a todos os atores envolvidos nesta área.

Necessário se faz sensibilizar os gestores públicos municipais destas evidencias, de modo a comprometê-los com as questões de segurança pública nesta direção. Por outro lado, defender o aporte de recursos para que os GGI-Ms e Observatórios sejam implantados de modo a potencializar a capacidade do ente municipal nas políticas de segurança no âmbito municipal.

Finaliza-se que a segurança pública é condição essencial para que todas as pessoas possam viver em paz e para a população mais sacrificada dos bairros periféricos das cidades, conflagrados pela violência, tenham um tratamento digno e respeitador, sem violação de direitos. 


\section{Referências}

AZEVEDO, Rodrigo Ghiringhelli de. A municipalização da segurança pública: Bases teóricas e experiências de implementação do RS. 2007.

BARDIN, Laurence. Análise de Conteúdo. Lisboa, Portugal. Edições 70, LDA, 2009.

BRASIL. Presidência da República. Secretaria Especial de Políticas para MuIheres. Segurança Pública - Outros olhares, novas possibilidades / editado por Aparecida Gonçalves, Ane Teixeira da Cruz; organização de João Trajano Sento-Sé - Brasília: 2009, 176 p.

BRASIL, Constituição da República Federativa do Brasil. Brasília: Senado Federal, 1988. Disponível em: <http://www.planalto.gov.br/ccivil_03/constituicao/constituicao.htm> Acesso em: 27 de jul. 2014.

Lei Federal no. 11.530, de 24 de outubro de 2007. Institui - Programa Nacional de Segurança Pública com Cidadania - PRONASCI e dá outras providências. Disponível em: <http://www. planalto.gov.br/ccivil_03/_ato2007-2010/2007/Lei/L11530.htm>. Acesso em: 10 abril 2015.

Medida Provisória no 416, de 23 de Janeiro de 2008. Altera a Lei no 11.530, de 24 de outubro de 2007, que institui o Programa Nacional de Segurança Pública com Cidadania - PRONASCI, e dá outras providências. Disponível em: <http://www2.camara.leg.br/legin/fed/medpro/2008/medidaprovisoria-416-23-janeiro-2008-569168-norma-pe.html>. Acesso em: 24 de abril de 2015.

Ministério da Justiça. Programa Nacional de Segurança Pública com Cidadania (PRONASCI). Disponível em: < http://www.observatoriodeseguranca.org/seguranca/pronasci>. Acesso em: 26 de abril de 2015.

BUENO, Antonio da Silveira (Org.). Dicionário Estudantil da Língua Portuguesa. São Paulo: FTD, 2007.

CANOAS. Lei Municipal no. 5.386, de 19 de maio de 2009. Cria o Conselho Municipal de Segurança Pública, reestrutura o Gabinete de Gestão Integrada Municipal e dá outras providências. Disponível em: < https:// www.leismunicipais.com.br/a/rs/c/canoas/lei-ordinaria/2009/539/5386/ lei-ordinaria-n-5386-2009-cria-o-conselho-municipal-de-seguranca-publica-reestrutura-o-gabinete-de-gestao-integrada-municipal-e-da-outras- providencias?q=5.386\%2F2009> Acesso em: 27 de abril de 2015 . 
Lei Municipal no $\mathbf{5 . 8 0 1}$, de 16 de Dezembro de 2013. Altera a Lei no 5.386, de 19 de maio de 2009, que cria o Conselho Municipal de Segurança Pública, reestrutura o Gabinete de Gestão Integrada Municipal e dá outras providências. Disponível em: https://www. leismunicipais.com.br/a/rs/c/canoas/lei-ordinaria/2013/581/5801/lei-ordinaria-n-5801-2013-altera-a-lei-n-5386-de-19-de-maio-de-2009-que-cria-oconselho-municipal-de-seguranca-publica-reestrutura-o-gabinete-de-gestao-integrada-municipal-e-da-outras-providencias? $q=$ Lei\%20n\%BA\%20 5801\%2F2013 Acesso em 28 de abril de 2015.

CARTILHA. Gabinete de Gestão Integrada Municipal - GGI-M. - 2009. Impresso no Brasil - Edição e distribuição. MINISTÉRIO DA JUSTIÇA - Secretaria Nacional de Segurança Pública. Disponível em: < http://www.al.rs. gov.br/FileRepository/repdcp_m505/CSP/cartilha_GGIM.pdf>. Acesso em 15 de abril de 2015.

COSTA, Ana Paula Mota. Revista Virtual Textos \& Contextos, População em situação de rua. 2005

DAL SANTO, Rafael; KERBER, Aline de Oliveira. Estudo dos homicídios em Canoas (2009). Relatório de pesquisa, 2010. Disponível em: < http:// www.forumseguranca.org.br/storage/download//estudo_de_homicidios_ em_canoas.pdf >. Acesso em: 14 abr. 2015.

GIL, Antonio Carlos. Como Elaborar Projetos de Pesquisa. 5. ed. São Paulo: Atlas, 2008.

LAKATOS, Eva Maria; MARCONI, Marina de Andrade. Fundamentos de metodologia científica. São Paulo: Atlas, 1991. 270p.

MIRAGLIA, Paula. Segurança pública e violência. In: LIMA, Renato Sérgio. PAULA, Liana de (org.). Segurança Pública e Violência. São Paulo: Contexto, 2006.

PRANDINI, Janine; BERGONCl, Pâmela. Reivindicações e denúncias: subsídios para o planejamento do Plantão Integrado de Fiscalização. Relatório de pesquisa, Canoas, RS, 2011.

PAZINATO DA CUNHA, Eduardo; KERBER, Aline; DAL SANTO, Rafael. Observatório de Segurança Pública de Canoas: Contribuições à gestão pública municipal da segurança. 2013. Disponível em < http://revistaseletronicas.pucrs.br/ojs/index.php/civitas/article/viewFile/9942/9688>. Acesso em 31 de mar de 2015.

RAMOS, Cícero Moteran. Manual de Gestão de Segurança - Para Em- 
presas, Estatais e Comunidade. Belo Horizonte: Armazém das Idéias, 2007. RELATÓRIO DE ATIVIDADES. Implantação do Sistema Único de Segurança Pública. Tiragem: 2 $2^{\underline{a}}$ edição - 2007 - 8.000 exemplares. Impresso no Brasil - Edição e distribuição. MINISTÉRIO DA JUSTIÇA - Secretaria Nacional de Segurança Pública. Disponível em: < http://www.dhnet.org.br/dados/ relatorios/r_senasp/r_senasp_susp_2007.pdf>. Acesso em 25 de abril de 2015.

ROLIM, Marcos. Estudo de perfil de homicídios ocorridos em Canoas, RS. Relatório de pesquisa, 2009.

SOARES, L. E. Gabinete de Gestão Integrada de Segurança Pública: gênese; implantação; desdobramentos. In: Gabinetes de Gestão Integrada de Segurança Pública: coletânea 2003-2009. Brasília: Secretaria Nacional de Segurança Pública, 2009.Disponível em: < http://www.seguranca.mt.gov. br/UserFiles/File/livro\%20GGl\%20capa\%20verde.pdf>. Acesso em 31 de março de 2015.

SAMUEL, Luciane Boehm. O sistema de videomonitoramento em Porto Alegre. Porto Alegre: CAAPM, 2005.

SANTOS, Antônio Roberto Silva; NASCIMENTO, Elisângela Santana; OLIVEIRA, Fânia Santos de; SANTOS, Gilvan Edson de Souza dos; LACERDA, Vilma Maria Costa. Políticas públicas locais - Sistema Único de Segurança Pública - SUSP. 2008. Disponível em: < www.administradores.com.br/producao-academica/.../download/. Acesso em 26 de abril de 2015.

VERGARA, Sylvia Constant. Projetos e relatórios de pesquisa em administração. São Paulo: Atlas, 1998. Disponível em: http://pt.scribd.com/ doc/130890210/VERGARA-Sylvia-Constant-Projetos-e-Relatorios-de-Pesquisa-em-Administracao Acesso em: 27 de julho 2014.

YIN, Robert K. Estudo de Caso: Planejamento e Métodos. 2. ed. Porto Alegre: Bookman, 2001.

ZANELLA, Liane Carly Hermes. Apostila Metodologia de Estudo e Pesquisa em Administração - PNAP. Brasília: CAPES, 2009. 


\title{
A Arrecadação Tributária do Município de Glorinha/RS de 2001 a 2014: limites e possibilidades
}

\author{
Cristiano Oliveira de Souza ${ }^{1}$ \\ Rosa Angela Chieza²
}

\section{Introdução}

A despeito da descentralização de receitas tributárias ocorrida a partir da Constituição Federal de 1988, a gestão pública municipal enfrenta desafios no atendimento das demandas da sociedade. Demandas estas, em especial nas áreas de educação e saúde, as quais se alteram também em função das mudanças do padrão populacional, o qual aponta para o crescimento relativo da população de idosos.

O conjunto de normas implementadas no país desde 1988, alterou o controle e a fiscalização do Estado, as regras de destinação do gasto bem como da gestão de receita tributária nas três esferas. Neste cenário, a Lei de Responsabilidade Fiscal (LRF), vigente desde 2000, estabelece em seu artigo 11 que a instituição, previsão e efetiva arrecadação de todos os tributos de competência de cada Ente (União, Estados e Municípios) são requisitos da responsabilidade da gestão fiscal. Ou seja, a LRF, além de estabelecer limites de gastos com pessoal e de dívida, dentre outros, e normas de transparência e

Auditor fiscal do município de Glorinha, Pós-graduado em Gestão Pública Municipal pela UFRGS, Graduado em Administração de Empresas pela FACOS e Técnico em Contabilidade.

2 Profa de economia do Setor Pública na FCE/UFRGS e orientadora do TCC que originou este artigo. 
controle social, estabelece normas relativas à arrecadação da receita tributária de competência de cada Ente.

Neste sentido, os desafios da gestão pública municipal, além de se adequar ao novo marco regulatório, passam também não somente por atender uma demanda crescente por serviços públicos, mas por serviços públicos com mais qualidade e com maior especificidade, dada a alteração do padrão populacional brasileiro, que, reflete-se, também, em nível municipal.

Diante disso, é fundamental que os municípios priorizem ações com foco nas receitas tributárias próprias, sobre as quais têm autonomia conforme estabelece a Carta Magna de 1988 e assim possibilitem a redução do grau de dependência do Município em relação às transferências dos demais entes da federação.

O objetivo central desta pesquisa é, a partir da análise da composição e do comportamento das receitas tributárias arrecadadas (receitas próprias e de transferências governamentais) no município de Glorinha3, de 2001 a 2014, identificar potencialidades para ampliar a arrecadação própria do município, bem como propor planos de ações de melhoria da arrecadação a serem aplicados na área tributária.

Para atender aos objetivos propostos, além desta introdução, no Capítulo 2 apresentam-se as competências tributárias a partir da Constituição Federal do Brasil de 1988, em especial dos municípios brasileiros. No Capítulo 3 apresentam-se os impostos de competência municipal (IPTU, ISS e ITBI), suas respectivas alíquotas e fatos geradores, além das transferências do ICMS (imposto de competência estadual), a qual representa para o município de Glorinha 38,4\%, em 2014, da arrecadação municipal e por fim, apresenta-se a nova forma de tributação das Microempresas (ME) e Empresas de Pequeno Porte (EPP), o Simples Nacional. No capítulo 4, apresenta-se a análise sobre a composição e comportamento da arrecadação tributária do município estudado, bem como e os desafios e as propostas para o município de Glorinha ampliar a receita tributária. Por fim, apresentam-se as conclusões.

3 O Município de Glorinha foi criado em 1988 e está localizado na Região Metropolitana, há 50 quilômetros de Porto Alegre, com população estimada pelo IBGE em 7.443 habitantes em 2014. (GLORINHA, 2015). 


\section{2 - A Tributação no Brasil a partir da Constituição Federal de 1988}

A Constituição Federal do Brasil de 1891 (CF/1891) utilizou como modelo para definir o Sistema Tributário no Brasil o, existente no final do Império, levando em conta, o regime federativo em construção, sendo necessário que estados e municípios obtivessem receitas como garantia para obter autonomia financeira. Em relação à autonomia municipal, Prediger (2003) aponta que na CF / 1891 havia o interesse de os Estados-membros manterem o controle sobre os municípios, viabilizando o domínio político.

E assim a tributação no Brasil, desde 1891, passou por profundas transformações previstas nas reformas contidas nas Constituições federais de 1934, do Estado Novo de 1937, da retomada da democracia, em 1946 e do novo sistema tributário implementado pela ruptura institucional, em 1967.

Ao contrário da Constituição Federal de 1967, a qual centralizou os tributos na União, reduzindo assim, a autonomia dos estados e municípios e aumentando a dependência destes Entes às transferências federais (CHIEZA, 2008), a Constituição democrática e cidadã de 19884, fruto de um processo de participação coletiva, representou maior descentralização em favor dos entes subnacionais.

No Quadro 1 apresenta-se a distribuição das competências tributárias entre União, Estados e Municípios até a CF/1988 e as alterações ocorridas após a sua promulgação. Observa-se o aumento de competência aos municípios. O Imposto de Transmissão de Bens Imóveis Inter Vivos (ITBI) que era de competência estadual passou a ser de competência municipal. Além disso, o município ficou também com a competência do Imposto sobre a Venda do Varejo de Combustível (IVVC), o qual foi extinto em 1993. Os estados subnacionais passaram a ter competência para fixar suas alíquotas do ICMS, até então, ICM, e a União perdeu o direito de conceder isenções de impostos de competência dos Estados e Municípios. Além disso, os percentuais de

$4 \quad$ Os trabalhos para a redação da CF/1988 foram iniciadas através de 8 comissões temáticas, onde posteriormente foram integradas em uma outra comissão denominada de comissão de sistematização, que por sua vez, foram votadas em dois turnos em sessões plenárias (LEME, 1992). 
arrecadação do Imposto de Renda (IR) e do Imposto sobre produtos Industrializados (IPI) que eram destinados ao Fundo de participação dos Estados (FPE) e ao Fundo de Participação dos Municípios (FPM) foram ampliados e a transferência do ICMS dos Estados aos municípios foi ampliada de 20 para 25\% do total arrecadado . Assim, a CF/1988 possibilitou descentralização tributária, ampliando a autonomia dos entes federados. Apesar desta ampliação de competência tributária aos municípios, a carta Magna de 1988 manteve o que havia estabelecido na Constituição Federal de 1967 e no CTN, onde apenas a União tem competência para instituir novos impostos (CHIEZA, 2008).

Quadro 1 - Distribuição das competências tributárias até e a partir da Constituição Federal de 1988 entre União, Estados e Municípios

\begin{tabular}{|c|c|c|}
\hline Ente & Até a CF/1988 & A partir da CF/1988 \\
\hline União & $\begin{array}{l}\text { Importação } \\
\text { Exportação } \\
\text { Renda } \\
\text { Produtos Industrializados } \\
\text { Operações Financeiras } \\
\text { Propriedade Territorial Rural } \\
\text { Transportes Rodoviários } \\
\text { Serviços de Comunicações } \\
\text { Combustíveis e Lubrificantes } \\
\text { Energia Elétrica e Minerais } \\
\text { Taxa e Contribuição de Melhoria } \\
\end{array}$ & $\begin{array}{l}\text { Importação } \\
\text { Exportação } \\
\text { Renda } \\
\text { Produtos Industrializados } \\
\text { Operações Financeiras } \\
\text { Propriedade territorial Rural }{ }^{5} \\
\text { Grandes Fortunas } \\
\text { Taxa e Contribuição de Melhoria }\end{array}$ \\
\hline Estados & $\begin{array}{l}\text { Transmissão de Bens Imóveis } \\
\text { Circulação de Mercadorias } \\
\text { Veículos Automotores } \\
\text { Taxa e Contribuição de Melhoria }\end{array}$ & $\begin{array}{l}\text { Transmissão Causa Mortis e Doação } \\
\text { Circulação de Mercadorias e Serviços } \\
\text { Veículos Automotores } \\
\text { Taxa e Contribuição de Melhoria }\end{array}$ \\
\hline Municípios & $\begin{array}{l}\text { Propriedade Territorial Urbana } \\
\text { Serviços } \\
\text { Taxa e Contribuição de Melhoria }\end{array}$ & $\begin{array}{l}\text { Propriedade Territorial Urbana } \\
\text { Transm. de Bens Imóveis Inter Vivos } \\
\text { Serviços } \\
\text { Venda a Varejo de Combustível } \\
\text { Taxa e Contribuição de Melhoria }\end{array}$ \\
\hline
\end{tabular}

Fonte: Chieza (2008)

5 Através da Lei no 11.250/2005, a União, por intermédio da Secretaria da Receita Federal, poderá celebrar convênios com o Distrito Federal e os Municípios que assim optarem, visando a delegar as atribuições de fiscalização, inclusive a de lançamento dos créditos tributários, e de cobrança do ITR - Imposto sobre a Propriedade Territorial Rural, de que trata o inciso VI do art. 153 da Constituição Federal, sem prejuízo da competência supletiva da Secretaria da Receita Federal. 
A partir da CF/1988 os municípios passaram a ter competência sobre o IPTU, o ITBI que antes era estadual, e o ISS, além do recebimento de 50\% do da arrecadação do IPVA e do ITR ${ }^{6}$, além da partilha dos 25\% do ICMS. Segundo Miranda (2012) esta mudança redefiniu o pacto federativo brasileiro, caracterizando-o pela descentralização e pelo compartilhamento de competências entre os entes federados. Diante destas mudanças abordam-se, na Seção 3, os tributos de competência da esfera municipal bem como o ICMS, do qual os municípios recebem via transferência da esfera estadual, 25\% do produto de sua arrecadação, e o Simples Nacional.

\section{3 - Os Impostos de competência dos municípios, o ICMS e o Simples Nacional}

Apesar de a Carta Magna de 1988, em seu artigo 145 autorizar o Ente Municipal a instituir impostos, taxas e contribuição de melhoria, apresenta-se nesta Seção, somente os impostos de competência do Ente Municipal em função do seu maior peso na receita total em relação aos demais tributos (taxas e contribuição de melhoria). São eles, o Imposto Predial e Territorial Urbano (IPTU); o Imposto Sobre Serviços de Qualquer Natureza (ISS); e o Imposto de Transmissão de Bens Imóveis ( ITBI). Adicionalmente, aborda-se o ICMS e o Simples Nacional. O ICMS em função de sua complexidade na arrecadação total do município e do peso significativo da transferência de ICMS no total da arrecadação do município de Glorinha. De acordo com o Balanço do Município de 2014, disponibilizado no sitio do TCE/RS, o total da arrecadação do município foi de $\mathrm{R} \$ 28,9$ milhões sendo que a arrecadação de ICMS foi de $R \$ 11,1$ milhões, representando $38,4 \%$ do total da arrecadação no referido ano. Além disso, a receita de transferência de ICMS pode representar uma fonte potencial para Município ampliar sua arrecadação através da criação de programas específicos. E, o Simples Nacional, regime de arrecadação de tribu-

6 A Lei n 11.250/2005 autoriza os municípios a celebrar convênio com a RFB caso optarem por fiscalizar, lançar créditos tributários e cobrar o ITR, ficando assim, com 100\% da arrecadação deste tributo. 
tos e contribuições, sendo o principal foco, o repasse do ISS que é pago pelas empresas optantes deste regime.

\section{i. O Imposto Predial e Territorial Urbano (IPTU)}

Apesar da Carta Magna de 1988 em seu artigo 145 autorizar os Municípios a instituir impostos, taxas e contribuição de melhoria é o Código Tributário Nacional (CTN) ${ }^{7}$, quem define as condições para a cobrança sobre a propriedade imobiliária, autorizando lhes a definir os contornos de sua zona.

O Imposto Predial e Territorial Urbano (IPTU) compete ao município, conforme prevê a CF/1988:

Art. 156. Compete aos Municípios instituir impostos sobre:

I - propriedade predial e territorial urbana;

...

$\S 1^{\circ}$. Sem prejuízo da progressividade no tempo a que se refere o art. 182, $\S 4^{\circ}, 11$, o imposto previsto no inciso I poderá:

I - ser progressivo em valor do imóvel;

II - ter alíquotas diferentes de acordo com a localização e o uso do imóvel.

O IPTU é um dos tributos mais importantes devido ao seu potencial de receita dada a imobilidade do objeto, além de ser um instrumento eficaz na promoção do desenvolvimento locals.

O IPTU de Glorinha é regido pela Lei Municipal n 546/2002, Código Tributário Municipal (CTM). De acordo com o artigo $3^{\circ}$ do CTM, o IPTU incide sobre a propriedade, o domínio útil ou a posse a qualquer título de imóvel edificado ou não, situado na zona urbana do Município. O artigo $5^{\circ}$ define que a base de cálculo do imposto é sobre o valor venal do imóvel. Já as alíquotas são definidas no artigo $9^{\circ}$ conforme demonstrado no Quadro 2.

Lei no 5.172, de 25 de outubro de 1966.

8 Não é raro encontrar as Plantas Genéricas de Valores (PGV) e o Cadastro Imobiliário desatualizados. Neste sentido, Moraes, Pinto, Macedo e Araújo (2011) apontam como exemplo a própria cidade de Porto Alegre, que teve a última revisão total da sua PGV em 1992. 
Quadro 2 - Alíquotas do IPTU vigentes no Município de Glorinha/RS

\begin{tabular}{|c|c|c|}
\hline Imóveis & Valor venal & Alíquota- $\%$ \\
\hline \multirow{3}{*}{ Construídos } & Até $\mathrm{R} \$ 20.000,00$ & 0,3 \\
\cline { 2 - 3 } & De $\mathrm{R} \$ 20.000,01$ até $\mathrm{R} \$ 40.000,00$ & 0,4 \\
\cline { 2 - 3 } & Acima de $\mathrm{R} \$ 40.000,00$ & 0,45 \\
\hline Imóvel não edificado & Qualquer valor & 1,0 \\
\hline
\end{tabular}

Fonte: Lei Municipal n 546/2002. Elaboração própria.

Assim como no CTN, a lei municipal define em seu $\S 1^{\circ}$ do art. $3^{\circ}$ a necessidade de requisitos mínimos para cobrança de IPTU, de pelo menos a existência de dois dos melhoramentos citados a seguir:

Art. 3ำ 0 imposto sobre propriedade predial e territorial urbana incide sobre a propriedade, o domínio útil ou a posse a qualquer título de imóvel edificado ou não, situado na zona urbana do Município.

$\S 1^{\circ}$ - Para os efeitos deste Imposto, entende-se como zona urbana a definida em lei municipal, observado o requisito mínimo da existência de melhoramentos indicados em pelo menos 2 (dois) dos incisos seguintes:

I - meio fio ou calçamento com canalização de águas pluviais;

II - abastecimento de água;

III - sistema de esgotos sanitários;

IV - rede de iluminação pública, com ou sem posteamento, para distribuição domiciliar;

V - escola primária ou posto de saúde a uma distância máxima de 03 (três) quilômetros do imóvel considerado.

Para implementar a cobrança do IPTU é necessário que seja efetuado um levantamento de todos os imóveis existentes no perímetro urbano e que seja atribuído um valor a cada um deles. Para isto, é necessário que haja um processo de avaliação, atribuindo valor de mercado aos imóveis. 


\section{ii. O Imposto Sobre Serviços de Qualquer Natureza (ISS)}

O ISS está regulamentado através da Lei Complementar no 116/2003. O fato gerador do ISS, segundo a referida norma, é a prestação de serviços constantes na lista anexa da referida Lei, mesmo que tais serviços não constituam a atividade principal do prestador. Incide ainda sobre os serviços prestados com a utilização de bens e serviços explorados economicamente mediante autorização, permissão ou concessão, com o pagamento da tarifa, preço ou pedágio pelo usuário final do serviço (CARLIN, 2010). No caso, como exemplo, citamos os pedágios, que são cobrados nas estradas federais e estaduais, tendo a empresa concessionária de pagar ao município o ISS da arrecadação mensal dos pedágios das rodovias.

Segundo Azevedo (1998), a prestação de serviços vem de "uma obrigação de fazer", um negócio jurídico no qual uma parte se obriga a realizar um "fazer", ou seja, a prestar um serviço, tendo como contrapartida o pagamento desta prestação. A prestação dos serviços vem da obrigação de fazer.

A competência dos municípios cobrar o ISS encontra-se regulamentada na CF/1988 em seu artigo 156, inciso III:

Art. 156. Compete aos Municípios instituir impostos sobre: (...) III - serviços de qualquer natureza, não compreendidos no art. 155, II, definidos em lei complementar.

No Quadro 3 demonstra-se as alíquotas do ISS vigente do município de Glorinha.

Quadro 3 - Alíquotas do ISS vigente no Município de Glorinha/RS.

\begin{tabular}{|c|c|}
\hline Serviços do Anexo I da Lei Complementar 116/2001 & $\begin{array}{c}\text { Alíquota- } \\
\%\end{array}$ \\
\hline a) Serviços dos itens descritos nos subitens: $3.04,3.05,7.02,7.04$, & \\
$7.05,7.09,7.10,7.11,7.12,7.16,7.17,7.18,11.01,11.02,11.04$, & \\
$12.01,12.02,12.03,12.04,12.05,12.06,12.07,12.08,12.09$, & 3,00 \\
$12.10,12.11,12.12,12.14,12.15,12.16,12.17,16.01,17.05$, & \\
$17.10,20.01,20.02$ e 20.03 da lista referida no Item I deste anexo & \\
\hline
\end{tabular}




\begin{tabular}{|l|c|}
\hline $\begin{array}{l}\text { b) Serviços relacionados ao setor bancário ou financeiro, inclusive } \\
\text { aqueles prestados por instituições financeiras autorizadas a funcio- } \\
\text { nar pela União ou por quem de direito (subitem 15.1 a 15.18) }\end{array}$ & 5,00 \\
\hline c) Serviços de registros públicos, cartorários e notariais (subitem 21.01) & 5,00 \\
\hline d) Serviços de exploração de rodovia com pedágio (subitem 22.01) & 5,00 \\
\hline $\begin{array}{l}\text { d) Qualquer tipo de prestação de serviço não previsto nas letras ante- } \\
\text { riores deste item e os constantes dos itens I e III, quando prestados por } \\
\text { sociedade e não enquadrados em alíquota especificada neste Anexo }\end{array}$ & 2,00 \\
\hline
\end{tabular}

Fonte: Lei Municipal n 1.289/2010. Elaboração própria.

A CF/88 nos Atos das Disposições Transitórias (ADCT) em seu artigo 88 estabeleceu que a alíquota mínima do ISS seria de $2 \%$ (enquanto lei Complementar não disciplina o disposto) enquanto que a LC n $116 / 2003$ definiu em seu artigo $8^{\circ}$, inciso II que a alíquota máxima seria de 5\%. Portanto, conforme demonstrado no Quadro 3, no município de Glorinha as alíquotas variam de 2 a 5\% estando em conformidade com a legislação que regulamenta o tema.

\section{iii. O Imposto de Transmissão de Bens Imóveis (ITBI )}

O Imposto de Transmissão de Bens Imóveis e de Direitos a eles Relativos - ITBI é um tributo de competência municipal, definido pelo artigo 156, inciso II da CF/1988. A Carta Magna também estabelece que os municípios podem cobrar o ITBI apenas sobre os atos onerosos de transmissão inter vivos, a qualquer título, de bens imóveis, por natureza ou acessão física, e de direitos reais sobre imóveis (MORAES PINTO, MACEDO e ARAÚJO, 2011).

Já o CTN nos artigos 35 a 42 define as normas gerais aplicáveis ao ITBI, onde constam os conceitos do fato gerador, da base de cálculo e do contribuinte do imposto.

De acordo com o artigo 35 do CTN, o ITBI tem como fato gerador:

a) a transmissão, a qualquer título, da propriedade ou do domínio útil de bens imóveis por natureza ou por acessão física, como definidos na lei civil; 
b) a transmissão, a qualquer título, de direitos reais sobre imóveis, exceto os direitos reais de garantia;

c) a cessão de direitos relativos às transmissões referidas nos dois itens anteriores.

Moraes Pinto, Macedo e Araújo (2011) citam que a base de cálculo de um imposto, é o valor sobre o qual incide a alíquota para determinar o valor a ser pago pelo sujeito passivo. Ela é a expressão econômica do fato gerador. Os autores apontam também que a base de cálculo é um dos aspectos quantitativos do fato gerador do ITBI. Sobre a base de cálculo é aplicada a alíquota definida na lei municipal, que também é outro aspecto quantitativo do fato gerador.

No município de Glorinha, o artigo 54 do CTM define como fato gerador do ITBI "o valor venal do imóvel objeto da transmissão ou da cessão de direitos reais a ele relativos e na instituição ou extinção do usufruto, no momento da avaliação fiscal".

A alíquota do ITBI do Município de Glorinha está definida no CTM em seu artigo 57:

Art. 57 - A alíquota do imposto é:

I - nas transmissões compreendidas no Sistema Financeiro da Habitação:

a) sobre o valor efetivamente financiado: 0,5\% (meio por cento);

b) sobre o valor restante: $2 \%$ (dois por cento);

II - nas demais transmissões: $2 \%$ (dois por cento).

$\S 1$ - A adjudicação de imóvel pelo credor hipotecário ou a sua arrematação por terceiro estão sujeitas à alíquota de $2 \%$ (dois por cento), mesmo que o bem tenha sido adquirido, antes da adjudicação, com financiamento do Sistema Financeiro de Habitação.

$\S 2^{\circ}$ - Considera-se como parte financiada, para fins de aplicação da alíquota de 0,5\% (meio por cento), o valor do Fundo de Garantia por Tempo de Serviço - FGTS liberado para a aquisição do imóvel. 
Pode ser verificado através do artigo citado acima que a alíquota normal do Município de Glorinha é de $2 \%$ a não ser nos casos de financiamento no Sistema Financeiro de habitação que reduzem para 0,5\%.

Operacionalmente, o município de Glorinha encontra-se fazendo todo o trâmite de liberação das guias de ITBI através da internet para assim, facilitar o trabalho dos funcionários do Setor Tributário, e para evitar que o contribuinte e funcionários do cartório tenham que se deslocar até a prefeitura para solicitar a avaliação de um imóvel que será transmitido a outrem.

\section{iv. O Imposto Sobre Operações relativas à Circulação de Mercadorias e sobre Prestações de Serviços de Transporte Interestadual e Intermunicipal e de Comunicações (ICMS)}

O ICMS é um imposto de competência dos estados e do distrito federal estabelecido na CF/1988 em seu artigo 155, inciso II e parágrafo $2^{\circ}$. A norma também estabelece que é um tributo que deve ser partilhado com os municípios, através da transferência de 25\% de sua arrecadação aos municípios do respectivo Estado subnacional. A seguir demonstra-se como ocorre a partilha do ICMS entre os municípios do Rio Grande do Sul, de acordo com a Lei estadual $n^{\circ}$ $11.038 / 1997$.

O ICMS tem como fato gerador as operações relativas à circulação de mercadorias e às prestações de serviços de transporte interestadual e intermunicipal e de comunicação, ainda que as operações e as prestações se iniciem no exterior (CARLIN, 2010). Do total da arrecadação do referido tributo, 25\% deve ser repassado aos municípios de acordo com o artigo 158, inciso IV da CF/1988.

Os critérios para a distribuição dos $25 \%$ do ICMS arrecadado estão previstos na lei estadual. No caso do Rio Grande do Sul eles estão previstos na Lei estadual $n^{\circ} 11.038 / 1997$, que fixa os índices que influenciam no repasse de ICMS aos municípios, conforme demonstrado no Quadro 4. 


\section{Quadro 4- Requisitos que definem a distribuição das Transferências de ICMS aos municípios do RS 9 .}

\begin{tabular}{|l|c|}
\hline Requisitos $^{10}$ & Índices - em \% \\
\hline Valor Adicionado Fiscal & 75 \\
\hline População & 7,0 \\
\hline Área & 7,0 \\
\hline Propriedades rurais & 5,0 \\
\hline Valor Adicionado Fiscal Per capita & 2,0 \\
\hline Média da Produtividade Primária & 3,5 \\
\hline PIT & 0,5 \\
\hline
\end{tabular}

Fonte: Lei estadual nำ 11.038/1997. Elaboração própria.

Conforme demonstrado no Quadro 4, o Valor Adicionado Fiscal (VAF) é o item que mais influencia (75\%) no retorno do ICMS aos municípios, ou seja, o critério mais relevante para o volume de ICMS recebido como transferência, que leva em conta o fato gerador do referido imposto no respectivo município. A Lei Complementar $n^{\circ}$ 63/1990 define o VAF como o valor das mercadorias de saídas, acrescido do valor das prestações de serviços, no município, deduzindo o valor das mercadorias entradas, em cada ano civil. Em resumo seria o valor das saídas menos o valor das entradas.

A seguir, apresentam-se as normas estabelecidas pelo Simples Nacional, uma vez que as empresas optantes deste regime (Microempresas, Empresas de Pequeno Porte e Micro Empreendedor Individual (MEI)), que são prestadoras de serviço, contribuem com o ISS, cuja competência é municipal.

9 Antes do ano de 2012 havia também no cálculo do índice do ICMS a Taxa de evasão escolar e de mortalidade infantil, que deixaram de ser utilizadas com base na Lei ํㅡ 13.028, de 16/08/2008, devido inúmeras contestações de municípios, os quais alegavam injusta a utilização deste critério no cálculo.

10 Valor Adicionado Fiscal - Calculado com base no valor adicionado nas operações relativas ao ICMS realizadas em cada município e o valor adicionado total no RS; População - Calculado com base na população residente no município e a residente no Estado; Área - Calculado com base na área do município, e a área calculada do Estado, em quilômetros quadrados; Propriedades rurais - Calculado com base no número de propriedades rurais cadastradas no município e o das cadastradas no Estado; Valor Adicionado Fiscal Per capita - Calculado com base no valor adicionado fiscal "per capita" dos municípios; Média da Produtividade Primária - Calculado com base na produtividade primária do Município e a do Estado, considerando a média dos últimos 3 (três) anos anteriores à apuração; PIT - Programa de Integração Tributária - Projeto Parceria entre o Estado e os municípios. 


\section{v. O Simples Nacional}

O Simples Nacional é um regime opcional de arrecadação de tributos devidos pelas Microempresas (ME) e Empresas de Pequeno Porte (EPP) que unificou a arrecadação de 08 (oito) impostos e contribuições - 06 (seis) federais (Imposto sobre a Renda da Pessoa Jurídica (IRPJ), Imposto Sobre Produtos Industrializados (IPI), Contribuição Social sobre o Lucro Líquido (CSLL), PIS/Pasep, Contribuição para Financiamento da Seguridade Social (COFINS) e INSS Patronal), um estadual (ICMS), e um municipal (ISS).

$O$ artigo $3^{\circ}$ da LC $n^{\circ}$ 123/2006 define o conceito de ME e EPP, considerando-as a sociedade empresária, a sociedade simples e o empresário conforme definido no artigo 966 do Código Civil Brasileiro (CCB) ${ }^{11}$, tendo os mesmos, que estarem devidamente registrados na Junta Comercial.

Denominado como "Estatuto Nacional da Microempresa e da Empresa de Pequeno Porte", essa Lei objetivou reduzir a burocracia para as ME e EPP, com tratamento diferenciado em licitações, e financiamentos específicos para este segmento, créditos, dentre outras. $\mathrm{E}$, também objetivou fomentar o desenvolvimento e a competitividade das ME, das EPP e dos Microempreendedores Individuais (MEI), prevendo um sistema legal uniforme, facilitando o entendimento e o cumprimento das obrigações.

Os artigos 12 a 41 da LC $n^{\circ}$ 123/06 legislam sobre o Simples Nacional, que, conforme visto anteriormente, é um Regime Especial Unificado de Arrecadação de Impostos e Contribuições devidos pelas ME e EPP, vigente desde $1^{\circ}$ de julho de 2007.

Para que a empresa se enquadre no Estatuto Nacional da ME e EPP e no Simples Nacional, a LC $n^{\circ} 123 / 2006$ enquadrou as empresas de acordo com o seu faturamento bruto, sendo que o artigo $3^{\circ}$ conceitua a ME e a EPP, assim como o MEl é enquadrado através do artigo 18, de acordo com demonstrado no Quadro 5.

11 O artigo 966 do CCB conceitua o empresário da seguinte forma: "Considera-se empresário quem exerce profissionalmente atividade econômica organizada para a produção ou a circulação de bens ou de serviços. Parágrafo único. Não se considera empresário quem exerce profissão intelectual, de natureza científica, literária ou artística, ainda com o concurso de auxiliares ou colaboradores, salvo se o exercício da profissão constituir elemento de empresa". 


\section{Quadro 5: Enquadramento das empresas no Simples Nacional segundo o Estatuto Nacional da Microempresa e da Empresa de Pequeno Porte.}

\begin{tabular}{|c|c|c|}
\hline ESPÉCIES & LEGISLAÇÃO & FATURAMENTO BRUTO \\
\hline Microempresa - (ME) & Microempresa - (ME) & $\begin{array}{c}\text { Igual ou inferior a } \mathrm{R} \$ \\
360.000,00\end{array}$ \\
\hline $\begin{array}{c}\text { Empresa de Pequeno Porte } \\
\text { - (EPP) }\end{array}$ & Art. 3, inciso II & $\begin{array}{c}\text { Superior a } \mathrm{R} \$ 360.000,00 \text { e } \\
\text { igual ou inferior a } \mathrm{R} \$ \\
3.600 .000,00\end{array}$ \\
\hline $\begin{array}{c}\text { Micro Empresário Individual } \\
\text { - (MEI) }\end{array}$ & Art.18-A & Até $\mathrm{R} \$ 60.000,00$ \\
\hline
\end{tabular}

Fonte: LC n 123/2006. Elaboração própria.

A base de cálculo para o pagamento dos Impostos das empresas optantes do Simples Nacional está diretamente relacionada com a receita bruta ${ }^{12}$ da empresa, incluindo matriz e as filiais (caso exista), ou seja, de todos os estabelecimentos.

Portanto, conforme visto nesta seção, o Simples Nacional representa uma fatia de receita muito importante aos municípios, em função de as empresas com faturamento bruto interno de até 3,6 milhões (mais 3,6 milhões de exportação), que estejam enquadradas neste regime, e que sejam prestadoras de serviços, deverão repassar entre 2 a $5 \%$ de ISS aos municípios, de acordo com seu faturamento bruto, e conforme anexos III a VI da LC n 123/2006.

\section{4 - A tributação no município de Glorinha / RS: propostas e desafios}

A partir das normas tributárias vigentes no país, no Estado do Rio Grande do Sul e no município de Glorinha abordadas nas Seções anteriores, o objetivo desta seção é identificar quais as mudanças tribu-

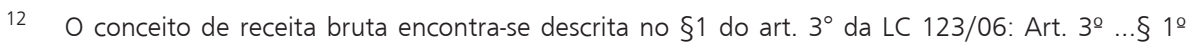
Considera-se receita bruta, para fins do disposto no caput deste artigo, o produto da venda de bens e serviços nas operações de conta própria, o preço dos serviços prestados e o resultado nas operações em conta alheia, não incluídas as vendas canceladas e os descontos incondicionais concedidos. 
tárias introduzidas pelo município de Glorinha, desde 2001, e no que contribuíram para explicar o comportamento da receita tributária total, e também nos seus desdobramentos no referido município. Objetiva-se adicionalmente identificar potencialidades do Município para ampliar a sua receita própria bem como apontar propostas que viabilizem a ampliação da receita tributária própria do município, contribuindo assim com a ampliação do grau de autonomia do referido Ente.

\section{1 - Metodologia}

Analisa-se o comportamento do Total da Receita Arrecadada do município de Glorinha/RS, no período de 2001 a 2014, segundo a classificação prevista na Lei $n^{\circ} 4.320 / 1964^{13}$. Serviram como fonte de dados, os balanços patrimoniais do município e do sítio do TCE - Tribunal de Contas do Estado do Rio Grande do Sul. Os dados foram atualizados a preços de 01 de janeiro de 2015, pelo Índice Nacional de Preços ao Consumidor Amplo (IPC-A) do Instituo Brasileiro de Geografia e Estatística (IBGE).

No Setor de Contabilidade, foram analisados os dados extraídos dos balanços patrimoniais informatizados do sistema de contabilidade. No Setor Tributário, analisou-se rotinas de trabalhos e procedimentos do setor. E, por fim, analisou-se políticas de modernização adotadas, ou em andamento, pela Gestão Tributária do município tendo como objetivo a ampliação da receita tributária. Os dados do PIB foram obtidos através do IBGE e do DATASUS, sendo estes dados referentes ao período de 2001 a 2012 (ano mais atual disponibilizado pela fundação). Efetuou-se o cruzamento de dados entre o referencial teórico e os dados coletados além da observação participante ${ }^{14}$, cotejando assim, a análise sobre o comportamento das receitas municipais e as propostas de modernização da gestão tributária.

13 No município de Glorinha não existe pessoa jurídica da administração indireta.

14 Segundo Haguette (1987), a observação participante é um processo onde ocorre a interação entre a teoria e os métodos dirigidos pelo pesquisador, a fim de buscar o conhecimento da perspectiva humana e, também, da própria sociedade. .Na observação participante, o pesquisador interage por longo período com os sujeitos, tornando-se uma ponte da situação observada, para, assim, partilhar o seu cotidiano, sentindo, de forma integrada, o que significa estar situado dentro de uma determinada situação (MAZZOTTI; CEWANDSZNAJDER, 1998). 


\section{2 - Da Arrecadação das Receitas Tributárias}

Inicialmente, analisa-se a Receita Tributária do município de Glorinha em relação às demais receitas correntes. Na Tabela 3 apresentase, em termos relativos, o comportamento das receitas tributárias em relação às transferências correntes, receita de serviços e patrimoniais, no período de 2001 a 2014.

\section{Tabela 1 - Percentuais das Receitas tributárias de Glorinha $\mathrm{x}$ demais receitas correntes comparado com o total das Receitas Correntes. Atualizado até 01/01/2015 pelo IPCA (FGV)}

\begin{tabular}{ccccccccc}
\hline & $\begin{array}{c}\text { Receita } \\
\text { Tributá- } \\
\text { ria }(\%)\end{array}$ & $\begin{array}{c}\text { Transf. } \\
\text { Corren- } \\
\text { tes }(\%)\end{array}$ & $\begin{array}{c}\text { Receitas } \\
\text { Serviços } \\
(\%)\end{array}$ & $\begin{array}{c}\text { Receitas } \\
\text { Patrimoniais } \\
(\%)\end{array}$ & $\begin{array}{c}\text { Rec. } \\
\text { Agropec. } \\
(\%)\end{array}$ & $\begin{array}{c}\text { Receitas } \\
\text { Contrib. } \\
(\%)\end{array}$ & $\begin{array}{c}\text { Outras } \\
\text { Receitas } \\
\text { Correntes } \\
(\%)\end{array}$ & $\begin{array}{c}\text { Total } \\
(\%)\end{array}$ \\
\hline 2001 & 15,37 & 78,84 & 0,15 & 0,61 & 0 & 0 & 5,03 & 100 \\
2002 & 16,46 & 75,90 & 0,10 & 0,80 & 0 & 0 & 6,74 & 100 \\
2003 & 24,14 & 67,53 & 0,74 & 1,51 & 0 & 0 & 6,08 & 100 \\
2004 & 18,51 & 74,35 & 0,56 & 0,37 & 0,56 & 1,28 & 4,37 & 100 \\
2005 & 18,74 & 72,09 & 0,78 & 0,99 & 0,28 & 2,01 & 5,11 & 100 \\
2006 & 18,36 & 75,82 & 0,91 & 0,47 & 0,15 & 1,38 & 2,91 & 100 \\
2007 & 15,03 & 76,99 & 3,29 & 0,74 & 0,05 & 1,10 & 2,80 & 100 \\
2008 & 16,00 & 79,02 & 0,45 & 0,88 & 0,03 & 0,97 & 2,65 & 100 \\
2009 & 10,91 & 79,89 & 1,65 & 1,02 & 0,04 & 1,14 & 5,35 & 100 \\
2010 & 11,10 & 84,10 & 0,73 & 1,37 & 0,10 & 0,92 & 1,68 & 100 \\
2011 & 11,06 & 82,61 & 1,38 & 1,86 & 0,06 & 0,87 & 2,16 & 100 \\
2012 & 12,27 & 81,85 & 1,58 & 1,13 & 0,04 & 0,93 & 2,20 & 100 \\
2013 & 12,25 & 84,08 & 1,11 & 0,58 & 0,07 & 0,74 & 1,17 & 100 \\
2014 & 13,90 & 82,56 & 0,65 & 1,02 & 0,09 & 0,73 & 1,05 & 100 \\
\hline
\end{tabular}

Fonte: TCE/RS (2015). Elaboração Própria.

Os dados da Tabela 1 mostram, como esperado, que o valor das transferências governamentais são bem superiores em comparação às 
receitas tributárias, ficando em média 78,2\% sobre o total das Receitas Correntes. As Receitas tributárias obtiveram uma participação relativa maior durante os anos de 2001 a 2006, sendo que neste período obteve uma média de 18,6\%. O ápice desta arrecadação ocorreu em 2003, quando atingiu 24,14\% das receitas correntes. Esta participação mais elevada das receitas tributárias próprias no exercício de 2003 deve-se principalmente, ao alto valor arrecadado de ISS que praticamente dobrou em relação a 2002, chegando a $\mathrm{R} \$ 1,9$ milhão.

\section{O ISS}

Em relação ao ISS, até 1995, a arrecadação deste tributo estava centrada na contribuição dos profissionais liberais, cujo pagamento era realizado uma vez por ano. A arrecadação de ISS no município de Glorinha iniciou em 1995. O montante arrecadado naquele ano foi em torno de $\mathrm{R} \$ 43 \mathrm{mil}^{15}$. Em 1997 o município criou a Lei Municipal $n^{\circ} 265 / 1997$, com o objetivo de trazer novas empresas prestadoras de serviços para Glorinha, beneficiando-as da seguinte forma:

Poderá reduzir alíquota do Imposto Sobre Serviço de Qualquer Natureza, para empresas prestadoras de serviço:

Alínea 1 - Zero por cento (0\%), no primeiro ano de instalação; Alínea 2 - Um por cento (1\%), do segundo ao quinto ano de instalação;

Alínea 3 - Dois por cento (2\%), do sexto ao décimo ano de instalação.

Após o décimo ano de instalação, a empresa pagaria a alíquota de $3 \%$, que era aplicada no município à época. Portanto, com esta lei muitas empresas começaram a se instalar no município. Conforme Tabela 2, pode ser visto o aumento gradativo do número de empresas instaladas no município de Glorinha de 1996 a 2001.

15 Valor atualizado pelo IPCA até 01/2015. 
O município utiliza desde 2011 um Sistema Informatizado a fim de facilitar o pagamento do ISS pelas empresas prestadoras de serviço do município e por empresas de fora que venham a prestar serviço no município. Este sistema funciona on line através do sitio do município, no qual as empresas registram o seu faturamento e emitem boletos para pagamento em qualquer agência bancária do Brasil. Este sistema contribuiu com o aumento da arrecadação deste tributo.

Desde 2001 a arrecadação de ISS já era superior em relação aos demais impostos municipais, e apresentou um crescimento de $179,74 \%$ de 2001 a 2014. Este crescimento é explicado, em parte, pela utilização da DEISS (Declaração Eletrônica de ISS), que facilitou aos contribuintes a entrega da mesma e o recolhimento do referido imposto. O pico da arrecadação do ISS ocorreu em 2008, que foi no período que várias empresas tiveram seus benefícios fiscais encerrados (Lei no 265/1997 cujos benefícios vigoraram de 1997 a 2009), passando a contribuir com alíquotas de ISS normalizadas (2 e 3\%).

Conforme citado anteriormente, a arrecadação do ISS, apesar de ser maior que as outras receitas tributárias próprias, obteve um aumento menor $(179,74 \%)$ no mesmo período em relação aos demais impostos (IPTU e ITBI). A arrecadação de ISS do período não foi maior devido à saída de mais de 80 empresas prestadoras de serviços do município de Glorinha, que a partir de 2007 aderiram ao Simples Nacional para se beneficiarem com o Estatuto da ME e EPP.

\section{O IPTU}

O IPTU de Glorinha começou a ser cobrado no ano de 1991, e a título de ilustração, em 1994 o valor arrecadado relativo a este imposto, conforme balanço patrimonial foi de apenas $R \$ 18 \mathrm{mil}^{16}$. Já para os anos seguintes houve ampliação da arrecadação do IPTU, devido a possibilidade de apontamento por parte do Tribunal de Contas do Estado (TCE) de que o município não estava cobrando à dívida ativa relativa a este imposto. Em 1999 o Município aumentou a zona

16 Valor atualizado pelo IPCA até 01/2015. 
urbana da cidade e contratou empresa a fim de fazer o cadastramento dessas novas áreas para fins de cobrança de IPTU, além de atualização das construções no cadastro de IPTU.

Em contrapartida, o município ficou de 1996 a 2002 sem efetuar atualização da Planta Genérica de Valores (PGV) e do Custo Unitário Básico (CUB), impactando na desvalorização dos valores venais dos imóveis localizados na zona urbana do município. A partir do exercício de 2003 iniciou-se um trabalho de atualização dos valores dos imóveis através da correção monetária17 da PGV dos imóveis do centro do município, e do uso do "CUB Residencial Multifamiliar Bai$\mathrm{xO}^{\prime \prime 18}$, fazendo com que anualmente, os valores arrecadados de IPTU crescessem, em termos reais, uma média anual de 9,09\%.

Para o exercício de 2014 o município seguiu utilizando o CUB Residencial Multifamiliar Baixo que estava valendo $\mathrm{R} \$$ 959,24 (novecentos e cinquenta e nove reais e vinte e quatro centavos). O correto seria a utilização de um CUB específico para cada tipo de construção, sendo que na época foi adotado o CUB de valor mais baixo, para que os contribuintes não tivessem seu IPTU aumentado em demasia. O aumento de arrecadação do IPTU poderia ter sido maior se o município já tivesse efetuado uma atualização da PGV utilizando valores mais próximos a realidade do mercado imobiliário. O IPTU de 2014 representou apenas 0,95\% do total das receitas correntes.

Em todo este período analisado, a arrecadação do IPTU aumentou $227,31 \%$, sendo superior a correção monetária do período que foi de $128,3 \%$. Se o município de Glorinha tivesse atualizado de quatro em quatro anos sua PGV e seu cadastro imobiliário, teria evitado a desvalorização da PGV em relação ao mercado imobiliário e várias edificações que foram construídas neste período teriam sido lançadas no cadastro de IPTU, o que faria que o percentual de aumento de arrecadação de IPTU fosse superior a atual.

17 O Índice Geral de Preços do Mercado (IGPM) utilizado até 2012, e a partir de 2013 taxa SELIC.

18 O CUB é o Custo Unitário Básico da construção civil, onde através dele é definido o valor do custo de uma obra por metro quadrado. O CUB Residencial Multifamiliar Baixo segundo a norma técnica NBR 12.721/2006 da Associação Brasileira de Normas Técnicas (ABNT).é utilizado para o cálculo de edifício de até sete pavimentos. 


\section{O ITBI}

Em relação ao ITBI, antes do ano 2000 a cobrança do mesmo era realizada sem efetuar vistoria no local, sem saber se o que estava na Guia de Recolhimento do ITBI demonstrava a realidade. Além disso, a avaliação não era efetuada pelos fiscais tributários, mas sim pela Secretária da Fazenda que estava no comando à época. Atualmente, todas as avaliações são solicitadas pela internet e repassadas para que o fiscal tributário faça uma avaliação "in loco".

No período de 2001 a 2014 o ITBI obteve uma média anual de $29,5 \%$, sendo que teve dois anos que se sobressaíram em relação aos demais, que foi em 2006 e 2011. Em pesquisa ao sistema de arrecadação da Secretaria da Fazenda, não se verificou a ocorrência de transmissão de áreas com valores elevados que viessem a acarretar este aumento. O ITBI representou em 2014 1,18\% do total das receitas correntes.

No período analisado (2001 a 2014), a arrecadação de ITBI obteve a maior alta entre as receitas tributárias próprias, com um aumento de $513,07 \%$ no período, devido que as avaliações são realizadas "in loco" e de acordo com aquecimento do mercado imobiliário nacional e local.

\section{iv. A Dívida Ativa Tributária}

O município de Glorinha, através da administração fazendária municipal, a partir de 1996 iniciou pela primeira vez, a cobrança administrativa de IPTU, precedendo a cobrança judicial. Mas, devido que o valor da dívida em cobrança (exercícios de 1993 a 1995) era ínfimo, acabou tornando-se inviável a cobrança judicial, uma vez que os custos advocatícios excediam o valor a ser cobrado judicialmente. No entanto, apesar de não ter havido nenhuma cobrança judicial em 1997 foi arrecadado $\mathrm{R} \$ 50.885,76$.

Em 2001 foi iniciada uma nova cobrança administrativa, podendo neste ano efetuar uma cobrança judicial dos valores de 1996 a 2000, 
incluindo aqueles valores de anos anteriores que não tiveram sidos pagos por alguns contribuintes. Então, já em 2003 houve um aumento significativo na arrecadação de dívida ativa ( $R \$ 326.116,20)$, sendo que neste valor também está incluso pagamento de dívida ativa de ISS (Imposto Sobre Serviços de Qualquer Natureza), que neste ano, o município já possuía empresas de prestação de serviços com grandes faturamentos anuais. Este aumento de arrecadação da dívida ativa é decorrente de um projeto realizado pela Secretaria da Fazenda que atuava diretamente com os fiscais tributários exigindo melhorias de arrecadação, com o objetivo de atingir metas para um Programa de Qualidade que estava sendo implantado na secretaria.

$\mathrm{Na}$ tentativa de evitar que os valores lançados em dívida ativa de IPTU aumentem excessivamente, o município efetua de quatro em quatro anos a cobrança administrativa e judicial do valor referente a este imposto. Em 2009 o Município de Glorinha obteve a maior arrecadação advinda da Dívida ativa, gerando aos cofres públicos uma arrecadação de $\mathrm{R} \$ 581.520,68$.

Além da análise do que foi arrecadado de dívida ativa, verificouse quanto não foi cobrado de dívida ativa, e principalmente as dívidas que prescreveram sem que tenha sido encaminhado para cobrança judicial. Na Tabela 2 demonstram-se os débitos prescritos até 2009 a preços atualizados até abril de 2015.

Tabela 2 - Débitos prescritos do exercício de 2009 e anteriores (atualizados até 13/04/2015)

\begin{tabular}{lccc}
\hline Espécie de tributo & IPTU & ISS & Total \\
$\mathrm{N}^{\circ}$ Empresas & $95.756,88$ & $1.302 .637,62$ & $1.398 .394,50$ \\
\hline
\end{tabular}

Fonte: Software AR (Arrecadação de Receitas) Secretaria Municipal da Fazenda / Glorinha (2015)

Observa-se que em torno de 1,4 milhões prescreveram sem o encaminhamento à cobrança judicial. Dentre as razões destaca-se a precariedade de controles tributários da Secretaria da Fazenda do município, cenário que pune os contribuintes que honram seus com- 
promissos com o Município e beneficia o contribuinte que usa os serviços públicos sem honrar o pagamento de seus tributos.

\section{O ICMS}

Em relação às transferências de receitas de ICMS, o município de Glorinha obteve no período analisado um incremento de 535,66\%. Isto ocorreu principalmente devido a implantação da indústria Fibraplac Chapas de MDF S.A. no ano de 2001, que influenciou diretamente no aumento do Valor Adicionado Fiscal do município de Glorinha.

No quadro 6 demonstra-se o comportamento do Valor Adicionado Fiscal do município de 2001 a 2013.

\section{Quadro 6: Valor Adicionado Fiscal de Glorinha no período de 2001 a 2013}

\begin{tabular}{|c|c|c|}
\hline Exercício & Valor $(\mathrm{R} \$)$ & Percentual de Aumento \\
\hline 2001 & $12.543 .285,59$ & - \\
\hline 2003 & $14.232 .987,52$ & 577,11 \\
\hline 2004 & $96.372 .928,11$ & 59,34 \\
\hline 2006 & $153.555 .862,50$ & 55,61 \\
\hline 2007 & $238.954 .230,51$ & 14,79 \\
\hline 2008 & $274.302 .489,18$ & $-4,27$ \\
\hline 2009 & $262.584 .334,25$ & 34,5 \\
\hline 2010 & $353.178 .087,88$ & $-3,51$ \\
\hline 2011 & $340.765 .299,32$ & 19,32 \\
\hline 2012 & $406.610 .627,68$ & $-0,32$ \\
\hline 2013 & $405.298 .725,75$ & \\
\hline
\end{tabular}

Fonte: Secretaria Estadual da Fazenda / RS (2015). Elaboração própria.

O aumento de mais de 3.000 \% do VAF do município de 2001 a 2013 contribuiu com aumento do índice de retorno do ICMS, pois o VAF representa 75\% do total do índice de ICMS na distribuição da cota parte do ICMS para os municípios do Rio Grande do Sul. A 
partir de 2005 até o ano de 2010 o índice de retorno de ICMS se elevou consideravelmente de 0,039156 para 0,178941, até que se estabilizou. Este aumento ocorreu devido ao aumento do VAF do município por consequência da implantação da empresa Fibraplac. Assim como ocorreu aumento do índice de retorno do ICMS no período de 2005 a 2010, também ocorreram quedas a partir de 2012 que obtiveram como responsável a empresa Fibraplac. Isto ocorre devido que a mesma encontra-se em um declínio acentuado de seu faturamento desde 2012, o que ocasionará na redução de repasses de ICMS ao município. A redução do faturamento da empresa ocorre devido a atual crise financeira no país que está afetando o mercado de uma forma geral.

Esta queda no valor adicionado da empresa impactará negativamente no valor das transferências de ICMS ao município para 2016, que terá como base o ano de 2013 e 2014, no qual ocorreu uma redução de $42,91 \%$ no VAF da empresa.

Portanto, a pesquisa demonstra que há uma previsão de redução nas transferências governamentais de ICMS, principalmente a partir do exercício de 2016.

A seguir apontam-se desafios e propostas para que o município de Glorinha o sentido de implementar modernização na área tributária e ao fim ao cabo, ampliar se grau de autonomia fiscal.

\section{3 - Desafios e propostas para o município de Glorinha Ampliar a Receita Tributária}

Os resultados da pesquisa permitem apontar propostas e desafios ao município no sentido de implementar modernização na área tributária:

i) Recadastramento do IPTU: apesar do crescimento de 227,31\% da Receita de IPTU no período de 2001 a 2014, conforme demonstrado no Gráfico 1, há potencialidade para a ampliação da receita advinda deste imposto mediante recadastramento através de 
Geoprocessamento, dos imóveis construídos, localizados em zona urbana, e que ainda não estão sendo cobrado o referido imposto.

ii) Alteração na base de Cálculo do IPTU: o cálculo da Planta Genérica de Valores (PGV) dos imóveis urbanos de Glorinha encontra-se defasados em relação ao valor de mercado ${ }^{19}$, devido que 0 município tem aplicado apenas a correção monetária nos valores dos imóveis tributados. Na lei que define o cálculo de IPTU apresenta-se apenas a expressão "CUB" sem especificar qual seria o correto para cada tipo de construção. Portanto, é necessário que a legislação municipal seja alterada, definindo os valores de CUB pra cada tipo de construção (residencial, comercial, industrial).

iii) IPTU Progressivo20: na zona urbana de Glorinha está ocorrendo casos de especulação imobiliária, com áreas de grandes terras sem serem loteadas. Portanto é importante que o município altere seu Código Tributário Municipal incluindo alíquotas progressivas, para que estas áreas tenham seu IPTU aumentado ano após ano, até que os proprietários venham a lotear estas áreas não utilizadas.

iv) Planejamento e gestão da Dívida ativa: implementação de controle que aponte, de forma automática e informatizada a lista dos devedores para realizar a cobrança administrativa da dívida e, posterior cobrança judicial. Esta medida rompe com a cultura do devedor que conta com a incapacidade do Município de cobrar efetivamente seus tributos dos inadimplentes, dado o histórico de Glorinha conforme demonstrado nesta pesquisa, e também, contribui para ampliar a arrecadação e evitar apontamentos por parte do órgão de controle externo, o Tribunal de Contas do Estado. Além disso, os municípios podem, de forma extrajudicial, encaminhar para o Cartório de Protestos as certidões de dívida ativa dos contribuintes devedores. Esta cobrança é uma medida que viabiliza a cobrança de dívidas de valores

19 Pode-se citar como exemplo, que um imóvel baldio localizado no Centro do Município está avaliado pelo sistema de IPTU em $R \$ 10.000,00$, enquanto que o mesmo está sendo comercializado por $R \$$ $80.000,00$.

20 A Lei federal $\mathbf{n}^{\circ} \mathbf{1 0 . 2 5 7 / 2 0 0 1}$, na Seção III trata do Do IPTU progressivo no tempo. Além disso, outros municípios como Caxias do Sul/RS aprovaram lei municipal estabelece tributação progressiva para o IPTU. 
abaixo do custo de cobrança dos honorários advocatícios, impedindo a prescrição.

iv) Implantação de Nota Fiscal Eletrônica: em relação ao ISS, o município tem a opção de implantar o sistema de nota fiscal eletrônica de ISS para que a fiscalização municipal tenha maior controle sobre a movimentação fiscal das empresas ${ }^{21}$ estabelecidas em Glorinha. Além disso, a implantação da nota fiscal eletrônica auxilia no combate a evasão e a sonegação de impostos.

v) Maior controle e fiscalização em relação à apuração do IPM - Índice de Participação dos Municípios utilizado na transferência do ICMS: em relação ao ICMS, o município atualmente contrata uma empresa para efetuar a análise e o controle das declarações (Guia Informativa Anual22) entregues mensalmente para a Receita Estadual do RS, pelas empresas de Glorinha. Como o volume de declarações impactam diretamente no IPM, é importante que o município implemente maior controle sobre estas declarações, podendo ser através de fiscalização física por um fiscal tributário de carreira, evitando assim, que o município passe para um terceiro, uma tarefa exclusiva de estado, conforme aponta Bresser Pereira (1997) .

Atualmente a Prefeitura paga para esta empresa de assessoria $\mathrm{R} \$ 7.920,00$ anuais, enquanto que cada fiscal tributário (atualmente o setor possui dois) recebe anualmente em torno de trinta mil reais.

Ainda, em relação à arrecadação própria de 2014, observou-se que a participação do IFF foi de 83,31\%. Em segundo lugar está o

21 O aumento da industrialização no município de Glorinha ocorreu principalmente devido a instalação de uma indústria de chapas de MDF, no ano de 2003, que aumentou consideravelmente o Valor Adicionado Fiscal (VAF) do município. Para demonstrar o crescimento da industrialização no município, a seguir demonstra-se o comportamento da participação relativa (\%) deste setor em comparação com a produção e extração animal, que até então era a principal economia do município. O setor industrial destaca-se na economia do Município desde o ano de 2004 representando $83,9 \%$ do índice de ICMS, sendo que isto ocorreu após a instalação de indústrias tais como Fibraplac chapas de MDF SA e Divimec Tecnologia Industrial Ltda, pois em 2000 este setor representava apenas $21,5 \%$. A agricultura e pecuária representada no item "Produção \& extração animal" que representava em 2000 49,7\% da economia do município, reduzindo em 2013 para apenas 3,5\%. Este redução percentual não representou a redução em valores reais (R\$), mas sim o aumento significativo do VAF da industrialização.

22 É a declaração anual do movimento econômico-financeiro que deve ser prestada pelos contribuintes, à Receita Estadual, relativamente a cada estabelecimento 
ITBI com 9,24\%, devido a grande quantidade de transações imobiliárias ocorridas em 2014 no município de Glorinha. Em 3ํ- último lugar está o IPTU, representando apenas $7,45 \%$ do total da arrecadação dos impostos próprios do município. Estes dados podem indicar, potencialidade para ampliar a receita tributária do IPTU, cuja efetividade, necessita de vontade política da administração pública.

v) Apresentação anual dos Blocos de Produtores: o município poderia realizar conscientização junto aos produtores rurais, que venham a apresentar anualmente seus talões de produtores junto à prefeitura, para que estas notas fiscais sejam lançadas em sua totalidade a fim de gerar um incremento ao valor Adicionado do Município.

vi) Programa de Educação Fiscal: a Lei Municipal n¹.358/2011 instituiu o Programa Municipal de Educação fiscal, no entanto, o município não viabilizou a implementação do referido programa nas escolas do município. O município poderia incluir nos currículos das escolas municipais o projeto "Educação Fiscal" do Estado do RS, onde os(as) professores(as) do município recebem treinamento para dar aulas a seus alunos sobre assuntos fiscais, incluindo a necessidade de solicitação de notas fiscais quando vierem efetuar compras no comércio local. Este projeto aumentaria direta e indiretamente o retorno de ICMS ao município uma vez que a Lei estadual $n^{\circ} 11.037 / 1997$ inclui no cálculo o Programa de Integração Tributária (PIT), onde um dos temas é o Programa de Educação Fiscal.

vii) Políticas de atração de investimentos: O município deve retomar negociações com empresas a fim de articular uma política de atração de investimentos ao município. O município tem grandes possibilidades de conseguir trazer novas empresas ao município como fez no início da década passada, pois possui grandes áreas de terras disponíveis e encontra-se localizada estrategicamente próxima de Porto Alegre, estando a sua zona industrial localizada junto ao acesso da BR 290 (Free-way). Isto é importante para que o município não fique dependente de praticamente uma empresa grande, como é o caso da empresa Fibraplac Chapas de MDF Ltda. 


\section{Considerações finais}

Em linhas gerais, a Constituição Federal do Brasil de 1988 representou avanços em relação ao aumento da autonomia dos municípios comparativamente ao período anterior. No entanto, apesar deste avanço, em 2014, do total da arrecadação do país, a União tem competência sobre aproximadamente $70 \%$, os Estados $25 \%$, restando para os Municípios apenas 5\% desta arrecadação (Receita Federal, 2015) A partir de 2007, o Simples Nacional representou uma nova forma de tributação voltada para às Micro Empresas e Empresas de Pequeno Porte, com o objetivo inicial de unificar o pagamento de vários tributos em uma mesma guia de pagamento, com a proposta de no futuro unificar os tributos no Imposto sobre Valor Agregado (IVA) . No entanto, a partir da implementação do Simples Nacional, mudanças foram inseridas, como a criação em nível nacional do MEl, a isenção de alíquotas do ICMS para ME e a redução de alíquotas de ICMS para as EPP23, as quais resultaram na redução de repasses aos municípios. Esta redução ocorre devido que os valores de ICMS que viriam a ser pagos por estas empresas seriam divididos e repassados a todos os municípios do estado do RS, de acordo com seu índice de retorno de ICMS. Assim, a expectativa de os municípios do RS terem ampliação de receitas com a criação do Simples Nacional foi frustrada uma vez que o MEI paga apenas R\$5,00 de ISS por mês aos municípios e, além disso, as ME estão isentas do pagamento de ICMS e as EPP possuem redução de alíquota que variam de 3,79 a 43,78\%. Assim, os municípios necessitam adotarem políticas diferenciadas para ampliar a arrecadação própria.

Diante deste cenário, e partir da análise do comportamento da receita própria do município de Glorinha de 2010 a 2014, aponta-se um conjunto de mudanças que viabilizariam a modernização tributária, ampliando a arrecadação própria do Ente e ao mesmo tempo reduzindo seu grau de dependências da União e do Estado. Dentre

23 Isenção dada pelo Estado do RS através da Lei n 13.036/2008. 
as quais se destacam o recadastramento e a alteração da base de cálculo do IPTU, Planejamento e gestão da Dívida ativa, Implantação de Nota Fiscal Eletrônica,, maior controle e fiscalização em relação à apuração do IPM - Índice de Participação dos Municípios utilizado na transferência do ICMS e implementação efetiva do Programa de Educação Fiscal para que o município amplie sua participação no valor do ICMS .

Por fim, em relação à necessidade de mudança cultural no Brasil, em especial para que os Chefes do Executivo passem a incorporar também um perfil mais técnico, incorporando práticas que objetivem dinamizar e otimizar a administração pública municipal24 e também uma mudança cultural, incluindo o Poder Legislativo municipal, no sentido de romper com uma cultura ainda vigente de privilegiar determinados grupos em detrimento da coletividade e no sentido de se capacitarem sobre o histórico da Tributação no Brasil, na qual predomina impostos indiretos, em detrimento dos imposto diretos, os quais, exceto o Imposto de Renda ( IR) e o Imposto de Transmissão Causa Mortis e Doação de Quaisquer Bens ou Direitos (ITCD) todos os demais são de competência do ente municipal. Este movimento articulado, além de demonstrar potencialidade tributária dos munícipios no Brasil, aproximaria o sistema Tributário Brasileiro ao Padrão dos países desenvolvidos, desonerando o consumo em detrimento do patrimônio e renda, e também contribuiria para melhorar as relações federativas brasileiras, uma vez que ampliaria a participação do Ente municipal sobre "o bolo" tributário nacional. No entanto, este é um movimento político que requer ação coordenada e coletiva pelos municípios brasileiros ${ }^{25}$.

24 Neste sentido, a LRF através do seu artigo11, implementou mudança cultural nos município brasileiro uma vez que alguns municípios da região nordeste do Brasil, não arrecadavam tributos próprios. Hoje, estes, incorreriam na falta de responsabilidade na gestão fiscal.

25 No atual cenário do federalismo no Brasil, o ente municipal tem perdido sua capacidade de ação e inclusive, muitas vezes tornando-se um mero executor de políticas públicas concebidas pela União. 


\section{Referências}

ABNT, NBR 12721 - Avaliação de Custos Unitários e Preparo de Orçamento de Construção para Incorporação de Edifícios em Condomínio

- Procedimento. Rio de Janeiro, 2006.

AZEVEDO, Álvaro Vilaça. Curso de Direito Civil. Teoria geral das Obrigações. 7ª ed. São Paulo: RT, 1998.

BRASIL. Código Tributário Nacional e Constituição Federal. 12ª . Ed. São Paulo: Ed. Saraiva, 2006.

Constituição da República dos Estados Unidos do Brasil, de 24 de fevereiro de 1891. Disponível em: <http://www.planalto.gov.br/ ccivil_03/constituicao/constituicao91.htm>. Acesso em: 17 mar. 2015.

Constituição da República dos Estados Unidos do Brasil, de 16 de julho de 1934. Disponível em: <http://www.planalto.gov.br/ccivil_03/ constituicao/constituicao34.htm>. Acesso em: 17 mar. 2015.

Constituição dos Estados Unidos do Brasil, de 10 de novembro de 1937. Disponível em: <http://www.planalto.gov.br/ccivil_03/constituicao/constituicao37.htm>. Acesso em: 17 mar. 2015.

Lei no 4.320, de 17 de março de 1964. Estatui Normas Gerais de Direito Financeiro para elaboração e controle dos orçamentos e balanços da União, dos Estados, dos Municípios e do Distrito Federal. Disponível em: <http://www. planalto.gov.br/ccivil_03/leis/14320.htm>. Acesso em: 12 fev. 2015.

Lei $n^{\circ}$ 10.406, de 10 de janeiro de 2002. Código Civil Brasileiro. Institui o Código Civil. Disponível em <http://www. planalto.gov.br/ccivil_03/leis/2002/l10406.htm> Acesso em 05 ago. 2014.

Lei $n^{\circ} \mathbf{1 1 . 2 5 0}$, de 27 de dezembro de 2005. Regulamenta o inciso III do $\S 4^{\circ}$ do art. 153 da Constituição Federal. Disponível em <http:// www.planalto.gov.br/ccivil_03/_ato2004-2006/2005/lei/l11250.htm>. Acesso em 06 abr. 2015.

Lei Complementar no 63, de 11 de janeiro de 1990. Disp es sobre critérios e prazos de créditos das parcelas do produto da arrecadação de impostos de competência dos Estados e de transferências por estes recebidos, pertencentes aos Municípios, e dá outras providências. Disponível em: <http://www.planalto.gov.br/ccivil_03/leis/LCP/Lcp63.htm>. Acesso em: 06 mar. 2015. 
Lei Complementar no 101, de 4 de maio de 2000. Estabelece normas de finanças públicas voltadas para a responsabilidade na gestão fiscal e dá outras providências. Disponível em: <http://www.planalto.gov. br/ccivil_03/leis/lcp/lcp101.htm>. Acesso em: 06 mar. 2015.

Lei Complementar $n^{\circ} .116$ de 31 de Julho de 2003. Dispõe Sobre o Imposto Sobre Serviços de Qualquer Natureza, de competência dos Municípios e do Distrito federal, e dá outras providências. Disponível em: <http://www. planalto.gov.br/ccivil_03/leis/lcp/lcp116.htm>. Acesso em 04 ago. 2014.

Lei Complementar 123, de 14 de dezembro de 2006. Institui o Estatuto Nacional da Microempresa e da Empresa de Pequeno Porte. Disponível em: <http://www.receita.fazenda.gov.br/Legislacao/LeisComplementares/2006/leicp123.htm>. Acesso em 10 jan. 2015.

Receita Federal do Brasil. Carga Tributária no Brasil 2014: Análise por tributos e base de incidência. 2015. Disponível em: http://idg.receita.fazenda.gov.br/dados/receitadata/estudos-e-tributarios-e-aduaneiros/ estudos-e-estatisticas/carga-tributaria-no-brasil/29-10-2015-carga-tributaria-2014. Acesso em: 30/10/2015.

BRESSER PEREIRA, Luiz Carlos. A Reforma do Estado dos anos 90: Lógica e Mecanismos de Controle. Cadernos MARE-Ministério da Administração Federal e Reforma do Estado. Caderno1, Brasília-DF,1997

CARLIN, Everson Luiz Breda. Auditoria, planejamento e gestão tributária./ 1a ed., 2a reimpr./ Curitiba: Juruá, 2010.

CHIEZA, Rosa Angela. O Ajuste das Finanças Públicas à Lei de responsabilidade Fiscal. 196p. Tese de Doutorado - Programa de Pós Graduação em Economia - Universidade federal do Rio Grande do Sul, Porto Alegre, 2008.

DATASUS - Ministério da Saúde. Dados da população. Contagem e projeções intercensitárias, segundo faixa etária, sexo e situação de domicílio. Disponivel em: <http://www.2.datasus.gov.br/DATASUS/index.php?are$a=0206 \&$ VObj=http://tabnet.datasus.gov.br/cgi/deftohtm.exe?ibge/cnv/ pop>. Acesso em: 01 Abr. 2015.

GLORINHA, História. Disponível em: <http://www.glorinha.rs.gov.br/glorinha_rs/index.php?option=com_content\&view=article\&id=47\&ltemid=55> Acesso em: 10 abr. 2015.

Lei no 265/1997, de 15 de julho de 1997. Altera o Inciso II da Lei n¹06/92 e dá outras providências. Glorinha, 1992 
Lei no 546, de 31 de dezembro de 2002. Reestrutura o Cógigo Tributário do Município, consolida a legislação tributária e dá outras providências. Glorinha, 2002.

Lei no 1.289, de 30 de dezembro de 2010. Acrescenta-se a seção IV no capítulo único do título VIII com os artigos 139-A, 139-B, 139-C, 139D, 139-E, 139-F, acrescentam-se os parágrafos $7^{\circ}, 8^{\circ}, 9^{\circ}, 10,11,12,13 \mathrm{e}$ 14 no artigo 32, acrescentam-se os artigos 35-A, 35- B, 35-C, 35-D, 46-A e 129-A na Lei Municipal no 546, de 31 de dezembro de 2002, dá nova redação aos artigos 35, 36, 42, 44, 45, 48, 49, 137 e ao inciso $V$ do art. 144 da lei Municipal no 546, de 31 de dezembro de 2002, altera o item $V$ do anexo I da lei Municipal ํㅜ 546, de 31 de dezembro de 2002, e dá outras providências. Glorinha, 2010.

Lei no 1.358, de 14 de junho de 2011. Institui o Programa Municipal de educação Fiscal - PROMEF e o Grupo de Educação Fiscal Municipal - GEFIM, no Município de Glorinha, e dá outras providências. Glorinha, 2011.

Prefeitura Municipal de Glorinha. Relatório de dívidas - prescritas. Sistema ARcetil Administração de Receitas. Emissão: 07 mai. 2015.

Prefeitura Municipal de Glorinha. Relatório por Atividade. Sistema ARcetil Administração de Receitas. Emissão: 07 mai. 2015.

HAGUETTE Teresa M. F. Metodologias qualitativas na sociologia. Petrópolis (RJ): Vozes, 1987.

LEME, H. J. C.; O federalismo na Constituição de 1988: representação política e a distribuição de recursos tributários. Campinas. Dissertação (Mestrado em Ciência Política). Universidade Estadual de Campinas, 1992.

MAZZOTTI, Alda J. A.; GEWANDSZNAJDER Fernando. $\mathbf{O}$ método nas ciências naturais e sociais. São Paulo: Pioneiras, 1998.

MIRANDA, R. A. C. de. Cooperação Federativa entre administrações tributárias brasileiras: O Sistema Público de Escrituração digital como embrião do fisco federativo. Universidade da Amazônia - UNAMA. Programa de Mestrado em Administração. Belém - PA, 2012. Disponível em: <http:// www.unama.br/ppad/download/dissertacoes/dissert_2012/Dissert_Mestrado_Raimundo_Miranda.pdf>. Acesso em: 14 mar. 2015.

MORAES PINTO, Sérgio Luiz de; MACEDO, Alberto; ARAÚJO, Wilson José de (coord.) - Gestão Tributária Municipal e tributos Municipais. - São Paulo: Quartier Latin, 2011. 
PREDIGER, Carin. O município brasileiro e seu papel até 1988. Interesse Público, Porto Alegre: Notadez, ano 5, n. 20, jul.-ago., 2003.

RIO GRANDE DO SUL. Lei Estadual no 11.038, de 14 de novembro de 1997. Disponível em: <https://www.legisweb.com.br/legislacao/?id=153691>. Acesso em 05, ago, 2014.> Acesso em: 05 abr. 2015.

Lei Estadual № 13.028, de 16 de agosto de 2008. Altera a Lei no 11.038, de 14 de novembro de 1997. Disponível em: <http://www.al.rs. gov.br/filerepository/repLegis/arquivos/13.028.pdf>. Acesso em: 05 abr. 2015.

RIO GRANDE DO SUL. Lei estadual $\mathbf{n}^{\circ}$ 13.036, de 19 de setembro de 2008. Disponível em: < http://www.al.rs.gov.br/FileRepository/repLegisComp/Lei\%20n\%C2\%BA\%2013.036.pdf> Acesso em: 05 abr. 2015.

TRIBUNAL DE CONTAS DO ESTADO DO RIO GRANDE DO SUL. Controle Social - Consulta Receitas. Disponível em: <http://www1.tce.rs.gov.br/ aplicprod/f?p=20001:23:0\%::RP,23,26:>. Acesso em: 10 fev. 2015. 


\title{
O financiamento da Educação Básica e a execução da Política Pública de Educação Infantil: o caso do município de Farroupilha/RS
}

\author{
Diego Silvestrin ${ }^{1}$ \\ Camila Furlan da Costa ${ }^{2}$ \\ Rosária Lanziotti Moraes ${ }^{3}$
}

\section{Introdução}

A Constituição Federal de 1988 instituiu a educação como um direito de todos e um dever do Estado. A carta constitucional vinculou um percentual de 25\% das receitas dos impostos e transferências dos Estados, Distrito Federal (DF) e municípios para a educação. Esta vinculação busca garantir o financiamento público da educação, e por consequência garantir a implementação de políticas públicas nacionais de educação.

Além da Constituição Federal, a Lei de Diretrizes e Bases da Educação (LDB) de 1996 foi instrumento importante no reordenamento da educação no Brasil, pois ela distribuiu competências entre os entes federados. Os municípios brasileiros ficaram responsáveis pela imple-

Especialista em Gestão Pública Municipal - EA/UFRGS.

Mestre em Administração pela UFRGS. Professora Assistente da Universidade Federal do Pampa, orientadora do TCC.

3 Mestre em Educação pela PUC/RS, tutora de apoio na elaboração do TCC. 
mentação das políticas de educação básica que abrangem da pré-escolar ao ensino fundamental, com a cooperação técnica e financeira da União e dos Estados.

A Emenda Constitucional no. 14/1996 determinou que 60\% dos recursos repassados para a educação deveriam ser utilizados no ensino fundamental. Complementarmente, a Lei Federal no. 9.424/1996 instituiu o Fundo de Manutenção e Desenvolvimento do Ensino Fundamental e de Valorização do Magistério (FUNDEF). O Fundo entrou em funcionamento em todo o país em 1998 promovendo a distribuição de recursos conforme o número de alunos matriculados nos municípios (MACHADO, 2006).

Outro importante instrumento que contribuiu para valorização crescente da educação básica foi o Plano Nacional de Educação, instituído pela Lei Federal no. 10.172/2001. O plano previa a universalização do ensino fundamental, bem como a ampliação da duração do ensino fundamental para nove anos, com a entrada de crianças a partir dos seis anos de idade. A efetivação desses objetivos se deu com a Lei Federal nº. 11.114/2005 que estabeleceu a obrigação de matrícula na rede fundamental aos seis anos e a Lei Federal n‥ 11.274/ 2006 institui o ensino fundamental com duração de nove anos.

Em 04 de abril de 2013, foi promulgada a Lei Federal no. 12.796/2013, que alterou o artigo 31 da LDB e determinou a educação básica obrigatória e gratuita dos 4 aos 17 anos, tornando obrigatória a matrícula na pré-escola aos 4 anos de idade. A pré-escola passou a ter novas regras como o estabelecimento de avaliações e acompanhamento, com expedição de documentação atestando o desenvolvimento da aprendizagem. Também foi determinado que o período letivo fosse de 200 dias com carga horária mínima de 800 horas e exigência de frequência mínima de 60\%.

A rede pública municipal de ensino está se adequando para atender esse novo público e suas especificidades. Surgiram novas demandas referentes à estrutura física das escolas, pois foi necessário atender um número maior de alunos em escolas que não foram projetadas para atender crianças de quatro anos. Também foi necessário 
ampliar o quadro de professores com profissionais qualificados para desenvolver as potencialidades desses alunos. Houve um aumento na demanda de merenda escolar, assim como a necessidade de transporte escolar para essas crianças.

A partir destas alterações que ampliam o ensino básico, este estudo teve como objetivo compreender como a administração municipal implementou a política pública de matricular todas as crianças, a partir de 4 anos na rede básica municipal através dos recursos enviados pelo Governo Federal através do Fundo de Manutenção e Desenvolvimento da Educação Básica e de Valorização dos Profissionais da Educação (FUNDEB), Salário-Educação e Fundo Nacional de Desenvolvimento da Educação (FNDE). A partir deste objetivo foi escolhido o Município de Farroupilha no Rio Grande do Sul como estudo de caso. Para alcançar os objetivos, realizou-se uma pesquisa descritiva sobre os processos desenvolvidos pela Secretaria de Municipal de Educação (SME) na gestão da educação infantil para adequação à Lei Federal no. 12.796/2013.

\section{2- Políticas de Financiamento da Educação}

A política para o financiamento da educação no decorrer da história compreendeu três períodos: a) de 1549 a 1759, período que os Jesuítas tiveram exclusividade na educação pública e assinalou-se um afastamento da Coroa em relação ao financiamento da educação; b) da expulsão dos Jesuítas até o fim da República Velha (1930) na qual ocorreu à busca de fontes autônomas para a educação e a educação esteve por conta das dotações orçamentárias dos governos dos Estados e das Câmaras Municipais; e, c) da Constituição Federal de 1934 até a atualidade, caracterizado pela vinculação de um percentual mínimo de recursos tributários para o financiamento da educação (BARROS, MOREIRA, 2012).

O governo Vargas rompeu com antigas estruturas e construiu um novo modelo de Estado, incluindo no campo de educação. A Constituição de 1934 foi a primeira a instituir um Plano Nacional de 
Educação e estabelecer a política de vinculação de recursos a partir da arrecadação de impostos para a educação, apesar de ser foi extinta em 1937, foi retomada em 1946 (VIEIRA, 2007).

A Constituição de 1946 vinculou 10\% dos recursos da União e 20\% dos recursos do Município. Em 1946 foi criada a Lei Orgânica do Ensino Primário, através da aprovação do Decreto-Lei n. 8.529/1946. Já em 1961, a Lei de Diretrizes e Bases elevou o percentual da União de $10 \%$ para $12 \%$ (SENA, 2010). Porém, o golpe de 1964 representou um retrocesso tanto em relação à democracia como nos avanços das políticas de Estado, dado que a vinculação de recursos para a educação perde sua efetividade. Em 1967, a vinculação financeira de recursos para a educação perdeu seu status constitucional, já no ano de 1969 ela foi limitada aos municípios.

A partir dos anos 80, em um contexto de enfraquecimento dos governos militares, aprovou-se a Emenda Calmon de 1983. A emenda foi regulamentada pela Lei Federal no 7.348/1985 e previa a obrigatoriedade de aplicação de, no mínimo, 13\% pela União, e, por parte de estados, Distrito Federal e municípios de 25\% em educação.

A lenta transição para o regime democrático foi acompanhada de muita pressão popular. A inclusão de temas relativos ao financiamento da educação na agenda de discussões da Assembleia Nacional Constituinte foi efetivada com pressão de agentes ligados à causa. A Constituinte foi palco de disputas em torno do financiamento da educação, como as discussões entre a exclusividade ou não exclusividade da destinação de recursos públicos às instituições educacionais públicas. O texto constitucional contemplou algumas possibilidades de destinação de recursos públicos às entidades particulares e de concessão de bolsas de estudo a alunos do ensino fundamental e médio, as quais, entretanto, foram cercadas de condicionalidades (FARENZENA; LUCE, 2013).

A Constituição Federal de 1988 foi a primeira a dar destaque para a Educação, já no Capítulo II dos direitos sociais no art. 6ㅇ․ "são direitos sociais a educação, a saúde, a alimentação, o trabalho, a moradia, o lazer, a segurança, a previdência social, a proteção à 
maternidade e à infância, a assistência aos desamparados, na forma desta Constituição".

No art. 205, a CF/88 estabeleceu que "a educação, direito de todos e dever do Estado e da família, será promovida e incentivada com a colaboração da sociedade, visando ao pleno desenvolvimento da pessoa, seu preparo para o exercício da cidadania e sua qualificação para o trabalho". Quanto ao financiamento foi estabelecido no art. 212 que a União deve destinar, no mínimo, 18\% da sua receita resultante de impostos e, os estados e municípios, ao menos $25 \%$ da mesma base. Desse modo, a educação na CF/88 ficou sob a responsabilidade da União, Estados e Municípios sob forma de colaboração. Essa colaboração ocorre no financiamento da educação, estabelecendo uma vinculação da receita resultante de impostos dos governos (MACHADO, 2006). Desse modo, na CF/88 há um retorno ao modelo de financiamento da educação através da vinculação de receitas.

Em 1996, durante a tramitação da Lei no 9.394/1996, a Lei de Diretrizes e Bases da Educação Nacional (LDB), foram propostas mudanças sobre o financiamento da educação, pois devido à ineficiência na distribuição dos recursos da educação, não houve a universalização do ensino básico, conforme pactuado pela Constituição Federal de 1988.

A LDB, no art 5으, estabeleceu que o acesso à educação básica obrigatória e um direito público subjetivo. Para garantir a sua obrigatoriedade, surge a necessidade da criação de um fundo, o Fundo de Manutenção e Desenvolvimento do Ensino Fundamental e de Valorização do Magistério (FUNDEF). O FUNDEF vinculou 25\% da receita global dos Estados e Municípios com a Educação, sendo que 60\% do total foram destinados ao ensino fundamental. O fundo não significou o aporte de novos recursos para educação se comparado com o determinado pela CF/1988. Porém, foi criado um novo padrão de gestão da educação básica, que garante estrutura de caráter contábil de retenção em uma única conta e com valores repassados aos entes federados de forma proporcional ao número de matrículas (CURY, 2002). 
Acompanhando esse processo de municipalização, o impacto redistributivo do FUNDEF vai se invertendo ao longo da sua vigência e, já no ano de 2001, a receita dos municípios passa a representar 50\% mais em relação à sua contribuição - de 6,2 bilhões para 9,3 bilhões. Os maiores ganhos, entretanto, foram aferidos entre aqueles municípios das regiões mais pobres, representando, para os municípios do Nordeste, por exemplo, ganho de cerca de $85 \%$ em relação à contribuição realizada (OLIVEIRA; TEIXEIRA, 2008).

A Emenda Constitucional no. 14/1996 instituiu que o sistema de educação brasileiro operará em regime de colaboração, com a União atuando de maneira supletiva. Em seu Art. 3ำ são alterados os parágrafos $1^{\circ}$ e $2^{\circ}$ do Art. 211 da CF/1988 estabelecendo que a União exerça função redistributiva e supletiva para garantir a equalização de oportunidades educacionais e padrão mínimo de qualidade do ensino através de assistência técnica e financeira. Também foram acrescentados o $3^{\circ}$ e o $4^{\circ}$ deixando claras as responsabilidades de cada ente federativo: estados e DF atuarão prioritariamente no ensino fundamental e médio, e, caberá aos estados e municípios definir formas de colaboração para assegurar a universalização do ensino básico obrigatório.

Portanto, a LDB e a criação do FUNDEF fizeram parte de uma revisão da política pública de educação. Através das medidas tomadas determinou-se o papel de cada ente federativo, e ainda, a organização do financiamento da educação através de fundo buscou tornar a redistribuição de recursos efetiva.

$\mathrm{Na}$ avaliação da política de financiamento do ensino fundamental algumas falhas foram apontadas na estrutura do FUNDEF. Entre elas a desproporção na distribuição dos recursos entre os entes da federação, o foco somente no ensino fundamental, a focalização em critérios quantitativos e não qualitativos, além da insuficiência de recursos (SENA, 2010). A EC no. 53/2006 criou o Fundo de Manutenção e Desenvolvimento da Educação Básica e de Valorização dos Profissionais da Educação - FUNDEB para corrigir distorções identificadas na revisão da política de financiamento. O novo fundo atendeu antigas 
exigências, como a abrangência de todos os níveis da educação básicas, sendo regulamentado pela Lei Federal 11.494/2007.

Devido a maior abrangência do novo fundo, foi necessária uma suplementação de recursos, em decorrência, no art. 3ำ do capítulo da composição financeira foram especificadas as mudanças. Além do aumento de $15 \%$ para $20 \%$, também cresce o número de componentes que fazem parte da arrecadação para o fundo. Já faziam parte do FUNDEF as seguintes receitas: Fundo de Participação dos Estados e do Distrito Federal (FPE), Fundo de Participação dos Municípios (FPM), Imposto sobre Circulação de Mercadorias e Serviços (ICMS), Imposto sobre Produtos Industrializados para Exportação (IPI-Exp) e foram acrescentadas o Importo sobre Propriedade de Veículos Automotores (IPVA), Imposto sobre a Propriedade Territorial Rural (ITR), Imposto de Renda (IR) e Imposto de Transferência Causa Mortis (ITCM).

Igualmente, a complementação de recursos por parte da União foi regulamentada através da EC no 53 no seu Art. 2ํㅡ, inciso VII, alínea d. Modificando o art. 60 do Ato das Disposições Constitucionais Transitórias, ficando a União responsável (após o 4ํano) pela complementação de $10 \%$ dos valores do fundo.

Ainda no âmbito financeiro ficou definido que a distribuição dos recursos será pelo número de matrícula no âmbito de atuação prioritária do ensino básico (educação infantil e ensino fundamental, para os municípios, e ensino médio e ensino fundamental, para os estados).

Outro importante instrumento de financiamento da educação é o Fundo Nacional de Desenvolvimento da Educação (FNDE) que teve sua origem no período militar através da Lei no. 5.537/1968, com o objetivo de captar recursos financeiros para o desenvolvimento de programas destinados à educação. O FNDE tem estrutura de autarquia e está ligado ao Ministério da Educação. Ele presta assistência técnica e financeira aos estados e municípios, sua atuação está calcada no art. 211 da CF 88, é o exercício da função redistributiva e supletiva da União (CRUZ, 2009). 
A Lei no. 12.801/2013 impôs modificações ao FNDE acrescentando a alíneas "e" no art. 3ำ da Lei no 5.537/1968, possibilitando a assistência técnica e financeira para aperfeiçoar o processo de aprendizagem na educação básica pública, por meio da melhoria da estrutura física ou pedagógica das escolas.

Através do FNDE tenta-se criar um padrão de gestão de recursos na educação, o que reforça o caráter normativo da União frente ao sistema de educação. Notamos esses elementos no parágrafo 5ํㅡㄹ através dele ficou instituído que o FNDE disponibilizará bens, materiais pedagógicos e capacitação aos sistemas de ensino e de gestão dos programas educacionais, além de instrumentos administrativos, visando a promover a eficiência na execução das ações e projetos educacionais, inclusive em procedimentos licitatórios.

O FNDE atua no financiamento da educação de três formas de assistência financeira: direta, voluntária e automática. A assistência direta ocorre através do Programa Nacional do Livro Didático (PNLD) e do Programa Nacional Biblioteca na Escola (PNBE). O modo de assistência voluntária ocorre através do financiamento de projetos educacionais. Por fim, há o módulo de transferência automática, ele é realizado através de transferências legais em programas específicos: Programa Nacional de Alimentação Escolar (PNAE), Programa Nacional de Transporte Escolar (PNATE), Programa Dinheiro Direto na Escola (PDDE) e Pró-Infância.

Outra fonte de financiamento é o salário educação que consiste em uma contribuição social criada pela Lei Federal no․ 4440/64 e corresponde a 2,5\% da folha de pagamento das empresas vinculadas à Seguridade Social. Até 2003 a distribuição dos recursos era realizada da seguinte maneira: 1/3 para União e 2/3 para os estados. Porém, os municípios passaram a reivindicar o acesso aos repasses. Assim, a Lei Federal no. 9.766/1998 determinou que os recursos estaduais devessem ser redistribuídos com os municípios, porém, nem todos os estados efetivaram os repasses (CRUZ, 2009). 


\section{3 - A Educação Infantil no Brasil}

No Brasil, a educação infantil caracteriza-se pelo atendimento às crianças de 0 a 6 anos. A educação infantil segundo a LDB estabelece que crianças de 0 a 3 anos de idade devem ser atendidas em creches ou equivalentes, e crianças de 4 a 6 anos em pré-escola. Apesar de não se caracterizar como obrigatória, a Educação Infantil é um direito público. A responsabilidade constitucional para a oferta da pré-escola é dos municípios com o apoio das esferas federal e estadual (BRASIL, 2015). A educação infantil tem um papel importante no desenvolvimento da criança e de preparação para o ensino básica.

Diversas emendas constitucionais foram acrescentadas para a ampliação da oferta da educação infantil no Brasil. A EC n․ 53/2006 alterou 0 art. 70 da CF 88, adicionando como direito social o atendimento em creches e pré-escolas até os 5 anos. A educação infantil foi incluída como competência dos municípios no inciso VI do Art. 30. A EC no. 59/2009 em seu art. 1ํ alterou o Inciso I do Art. 208 da CF/1988, determinando que a educação básica fosse obrigatória dos 4 aos 17 anos.

A Lei Federal no. 12.796/2013 incluiu no seu Art. 4º, como dever do Estado a educação infantil gratuita às crianças de 4 e 5 anos de idade na pré-escola. Esta lei estabeleceu regras comuns de organização da educação infantil, introduzindo a avaliação mediante acompanhamento e registro do desenvolvimento das crianças; carga horária mínima anual de 800 (oitocentas) horas; turnos de atendimento parcial de no mínimo, 4 (quatro) horas diárias e integral de 7 (sete) horas; frequência pela mínima de $60 \%$ (sessenta por cento) do total de horas; documentação que ateste o desenvolvimento e aprendizagem da criança" (BRASIL, 2013).

Ainda, através do novo Plano Nacional de Educação (PNE) instituído pela Lei Federal no . 13.005/2014 foi definido que a meta 1 será universalizar, até 2016, a educação infantil na pré-escola para as crianças de 4 (quatro) a 5 (cinco) anos de idade. Além de ampliar a oferta de educação infantil em creches de forma a atender, no míni- 
mo, 50\% (cinquenta por cento) das crianças de até 3 (três) anos até o final da vigência do PNE.

Quanto ao financiamento da educação infantil, verificou-se anteriormente que todos os programas ligados ao FNDE foram revisitados para o atendimento à educação infantil. Além disso, o próprio FUNDEB e o salário educação que também passaram por alterações para incluírem a educação infantil.

\section{4 - Procedimentos Metodológicos}

A estratégia de estudo adotada foi o estudo de caso, visando conhecer como ocorreu o processo de execução da política pública de educação infantil determinado pela Lei Federal no . 12.796/2013 no município de Farroupilha - RS. Segundo Yin (2005, p.32) estudo de caso é "uma investigação empírica que investiga um fenômeno contemporâneo dentro de seu contexto da vida real, especialmente quando os limites entre o fenômeno e o contexto não estão claramente definidos".

O caso a ser estudado foi a gestão da educação infantil no Município de Farroupilha/RS. Foram escolhidas duas técnicas de análise de dados: a análise de documentos e a entrevista. As entrevistas foram realizadas com a Secretaria Municipal de Educação e com a Presidente do Conselho Municipal de Educação. As entrevistas tiveram como objetivo descrever como foi a realizada a implementação da Lei Federal no. 12.796/2013. A descrição dos procedimentos realizados foi acompanhada de uma avaliação dos recursos recebidos para a execução da política de educação infantil, assim foi possível analisar como a Secretaria Municipal de Educação realizou o processo de monitoramento da execução da política.

As entrevistas foram semiestruturadas, através da elaboração de um roteiro de entrevista composto por 14 questões para o Secretário Municipal de Educação e 10 questões para o presidente do Conselho Municipal de Educação. A escolha destes entrevistados deve-se pela representatividade e participação no processo de implementação da 
Lei Federal nº 12.796/2013. A técnica de análise de dados utilizada para tratar as entrevistas foi a análise interpretativa.

Foram considerados na análise de documentos como fontes de coletas de dados a legislação brasileira de educação e documentos contábeis do município de Farroupilha/RS, como o demonstrativo de receitas dos anos de 2013 e 2014. Através das informações colhidas foi possível realizar uma análise quantitativa das transferências da União referentes à educação para o município.

\section{5 - A Educação Infantil no Município de Farroupilha/RS}

O município de Farroupilha está localizado no Rio Grande do Sul e sua população é de 68.030 habitantes. Seu IDH em 2010 era de 0,777 , superior à média dos demais municípios do país. Em relação a rede de educação, segundo o IBGE, no ano de 2012 haviam 8.111 alunos matriculados no ensino fundamental, sendo que 5.556 alunos estavam matriculados nas 27 escolas da rede pública municipal que contavam com 344 docentes. No ensino pré-escolar haviam 1.174 matriculados, porém apenas 554 estavam na rede pública municipal que conta com 27 escolas e 34 docentes (BRASIL, 2012).

A partir destes dados, observa-se que o município estudado já apresentava um déficit I no atendimento pré-escolar, pois apenas $47 \%$ dos matriculados estavam em escolas do município, enquanto que no ensino fundamental este número sobe para $68 \%$. No comparativo entre o número de docentes de educação infantil na rede pública municipal e na privada, constata-se que na primeira há em média, 1 para 16 alunos, enquanto que na rede privada a média é de aproximadamente 1 professor para 10 alunos.

Este déficit com a educação infantil foi apontado pelo Tribunal de Contas do Estado (TCE) através de seu parecer no 08366/2014, que entre as principais deficiências do município: a) ausência de cumprimento das metas do Plano Nacional de Educação para a educação infantil; b) insuficiência de recursos na educação infan- 
til; c) necessidade de criação de vagas em creches e pré-escolas; c) perda de arrecadação do FUNDEB em função do não atendimento da comunidade escolar (RIO GRANDE DO SUL, 2014). A partir desde diagnóstico, é possível garantir que há a necessidade de maiores cuidados e investimentos na educação básica e a Lei Federal $n$ o 12.796/201 vai ao encontro deste objetivo. Por isso, este estudo ateve-se em analisar os fundos e programas de financiamento da educação nos anos de 2013 e 2014. O intuito dessa análise é verificar como os gestores municipais da educação adequaram à execução da política pública de educação infantil aos recursos disponíveis.

No Município de Farroupilha/RS, a educação infantil foi tratada no Plano Municipal de Educação (PME), ele foi aprovado pela Lei Municipal no. 3.224/2006. Entre as suas diretrizes estavam a universalização do atendimento de crianças de 0 a 5 anos, priorizando as crianças de famílias de menor renda. Além de respeitar os parâmetros da qualidade dos profissionais e do desenvolvimento de uma proposta pedagógica elaborada acompanhada da comunidade escolar.

Verifica-se que já no ano de 2006 havia a intenção de ampliar o percentual de crianças atendidas pela pré-escola. Além disso, nota-se a preocupação com a qualificação constante dos docentes.

No PME também foi realizado um diagnóstico da situação da educação infantil do Município no ano de 2014, na etapa pré-escola estavam matriculadas 1.489 crianças que totalizam $96,81 \%$ da população nesta faixa etária. Sendo que 928 foram atendidas nas escolas municipais e 115 nas escolas estaduais, totalizando 1.043 crianças atendidas gratuitamente em Farroupilha/RS.

A tabela 1 mostra a evolução do atendimento da pré-escola no Município estudado, e sua distribuição conforme na rede de ensino. Percebe-se que houve um crescimento mais significativo na oferta de vagas na rede municipal em 2014. 
Tabela 1- Quadro Demonstrativo de Atendimento da Pré-Escola em Farroupilha/RS

\begin{tabular}{|l|r|r|r|}
\hline Rede & 2012 & 2013 & 2014 \\
\hline Estadual & 51 & 47 & 57 \\
\hline Municipal & 550 & 563 & 905 \\
\hline Privada & 563 & 620 & 527 \\
\hline
\end{tabular}

Fonte: INEP/SEDUC/2014

A tabela 2 expôs a evolução das matrículas na educação infantil em escolas municipais no período de 2010-2014. Percebe-se que a expansão das vagas ocorreu em 2014, quando houve um aumento de $60,75 \%$ em relação ao ano de 2013 , fruto da implementação da Lei Federal no. 12.796/2013.

Tabela 2 - Evolução das matrículas em educação infantil

\begin{tabular}{ccc}
\hline Ano & Número de alunos & Variação \% \\
\hline 2010 & 540 & - \\
2011 & 513 & $-5,00 \%$ \\
2012 & 550 & $7,21 \%$ \\
2013 & 563 & $2,36 \%$ \\
2014 & 905 & $60,75 \%$ \\
\hline
\end{tabular}

Fonte: PME/SME 2014

O novo PME estabeleceu, entre suas metas a universalização, até anos de idade, bem como a ampliação da oferta de educação infantil em creches de forma a atender, no mínimo, 50\% (cinquenta por cento) das crianças de até 3 (três) anos até o final da vigência do PME. O plano municipal de educação de Farroupilha/RS priorizou a adequação à Lei 12.796/2013 e às metas expostas no Plano Nacional de Educação (PNE) e do Plano Estadual de Educação (PEE).

O município de Farroupilha tem primado pela valorização da educação infantil no Plano Municipal de Educação. Foi realizada uma abordagem que vai além do cumprimento de simples metas estatísticas, há o reconhecimento de que a política pública de educação infantil engloba aspectos de qualidade dos docentes, das estruturas físicas e de inclusão social. 
Porém, fica claro que as metas do PME, PEE E PNE na educação infantil deverão ser viabilizadas através de regime de colaboração entre os entes federativos. Nota-se que entre 2013 e 2014 o valor total do FUNDEB para o município de Farroupilha/RS aumentou em 17,3\%. Houve um acréscimo inicial de $\mathrm{R} \$ 3.743 .493,46$ para a manutenção da rede básica de educação no ano de 2014. Este valor inclui a criação de vagas para o atendimento das demandas geradas pela Lei Federal no. 12.796/2013.

\section{Tabela 3 - Resultado da arrecadação do FUNDEB pelo município de Farroupilha/RS}

\begin{tabular}{|c|c|c|c|}
\hline Ano & Previsão & Arrecadação & \multicolumn{1}{c|}{ Diferença } \\
\hline 2013 & $21.800 .000,00$ & $21.623 .256,50$ & $-176.743,50$ \\
\hline 2014 & $24.000 .000,00$ & $25.366 .749,96$ & $1.366 .749,96$ \\
\hline
\end{tabular}

Fonte: Elaborado pelos autores com base em dados do Portal da Transparência

Como já tratado anteriormente, desde a redemocratização a questão da educação entrou na agenda de governo e importantes ações foram tomadas no sentido de sua valorização. A criação do FUNDEF e do FUNDEB são os maiores exemplos, além da criação de fundos específicos para a alimentação escolar, para o transporte e para a construção de escolas.

A tabela 3 apresenta as principais transferências da União para o município de Farroupilha/RS nos anos de 2013 e 2014.

\section{Tabela 4 - Comparativo do total de receitas entre 2013 e 2014 pelo município de Farroupilha/RS}

\begin{tabular}{|l|r|r|r|}
\hline \multicolumn{1}{|c|}{ Recurso } & \multicolumn{1}{c|}{2013} & \multicolumn{1}{c|}{2014} & \multicolumn{1}{c|}{ Resultado } \\
\hline FUNDEB & $\mathrm{R} \$ 21.623 .256,50$ & $\mathrm{R} \$ 25.366 .749,96$ & $\mathrm{R} \$ 3.743 .493,46$ \\
\hline PRÓ INFÂNCIA & $\mathrm{R} \$ 100.000,00$ & $\mathrm{R} \$ 782.530,01$ & $\mathrm{R} \$ 682.530,01$ \\
\hline PNATE ED. INFANTIL & $\mathrm{R} \$ 15.466,92$ & $\mathrm{R} \$ 14.285,44$ & $-\mathrm{R} \$ 1.181,48$ \\
\hline PNAE PRÉ ESCOLA & $\mathrm{R} \$ 106.300,00$ & $\mathrm{R} \$ 98.910,00$ & $-\mathrm{R} \$ 7.390,00$ \\
\hline PDDE & $\mathrm{R} \$ 9.740,00$ & $\mathrm{R} \$ 5.670,00$ & $-\mathrm{R} \$ 4.070,00$ \\
\hline SALÁRIO EDUCAÇÃO & $\mathrm{R} \$ 1.625 .499,34$ & $\mathrm{R} \$ 2.002 .908,18$ & $\mathrm{R} \$ 377.408,84$ \\
\hline TOTAL & $\mathrm{R} \$ 23.480 .262,76$ & $\mathrm{R} \$ 28.271 .053,59$ & $\mathrm{R} \$ 4.709 .789,84$ \\
\hline
\end{tabular}

Fonte: Elaborado pelos autores através de dados do Portal da Transparência 
A partir do repasse dos recursos do PNATE é possível constatar que houve uma diminuição nos recursos de aproximadamente 12\% do total do fundo. Sendo que a redução foi de $8 \%$ no específico para a educação infantil. Esses recursos são utilizados apenas para o acesso à escola de estudantes da zona rural. Quando analisados os dados do PNAE, percebe-se que houve uma diminuição de aproximadamente 7\% entre 2013 e 2014 nas transferências do PNAE Pré-Escola. Este comportamento também pode ser percebido na análise do PDDE, uma vez que houve um decréscimo de $42 \%$ no total da transferência dos recursos.

Verifica-se que no ano de 2013 não houve transferência direta do Pró-infância para o município de Farroupilha/RS, porém, foi contabilizado uma verba no valor de $R \$ 100.000,00$ para a construção de escolas fundamentais. Já no ano de 2014 ocorreu uma grande evolução, o município captou o montante de $R \$ 782.530,01$ no Pró-Infância. Este aumento foi decorrente do cadastramento de projetos de construção de novas salas de aula para adequação à educação infantil pela prefeitura do município. Em contrapartida houve aumento do repasse de recursos no Salário Educação, que teve um saldo positivo de $R \$ 377.408,84$ entre os anos de 2013 e 2014 que corresponde a uma ampliação de $23 \%$ nos recursos.

Assim, o comparativo total entre as transferências do Governo Federal para Farroupilha demonstrou um acréscimo de receita na ordem de $R \$ 4.790 .789,84$ no ano de 2014, aumento percentual de $20 \%$. Na sequência do trabalho é analisado o crescimento da despesa devido às mudanças necessárias para se adequar à Lei Federal no 12.796/2013. Neste sentido, serão contabilizadas às despesas com obras de adequação nas escolas, contratação de docentes, transporte escolar e alimentação. Logo, com estes dados disponíveis será possível verificar se os $R \$ 4.790 .789,84$ foram satisfatórios para o aumento das despesas de custeio (dissídio coletivo e inflação) e para a adequação do município às novas exigências. 


\section{1 - Análise dos investimentos}

O Plano Municipal de Educação (PME) destacou a questão financeira algo central no desenvolvimento das ações referentes a educação infantil. O município de Farroupilha/RS desde 2010 investiu (Tabela 4) investiu em manutenção e desenvolvimento de ensino mais de 30\% da receita de impostos, em 2014 foram 33,77\%, muito acima dos 25\% estabelecidos pela CF/88. O percentual acima da recomendação constitucional permite ao município o cumprimento da Lei Federal no. 11.738/2008, ou seja, o pagamento do piso salarial e jornada de trabalho com no máximo $2 / 3$ em sala de aula e 1/3 para atividades de estudo, planejamento e avaliação. Portanto, grande parte dos recursos do FUNDEB foi utilizada no pagamento de professores do magistério.

\section{Tabela 5 - Percentual Investido em educação pelo município de Farroupilha/RS}

\begin{tabular}{cc}
\hline Ano & Percentual (\%) \\
\hline 2010 & 32,9 \\
2011 & 31,8 \\
2012 & 34,3 \\
2013 & 34,3 \\
2014 & 33,8 \\
\hline
\end{tabular}

Fonte: Elaborado pelos autores com base no PME/SME 2014

Em relação à Educação Infantil, o município de Farroupilha tem aumentado significativamente seus investimentos (Gráfico 1). O crescimento o recurso investido passou de 2,6 milhões em 2010 para 7,8 milhões em 2014, ou seja, um aumento de quase $200 \%$, o que ratifica o compromisso do município de ampliação da oferta de vagas para alunos de 0 a 6 anos. 


\section{Gráfico 1 - Evolução do investimento em Educação Infantil de Farroupilha/RS}

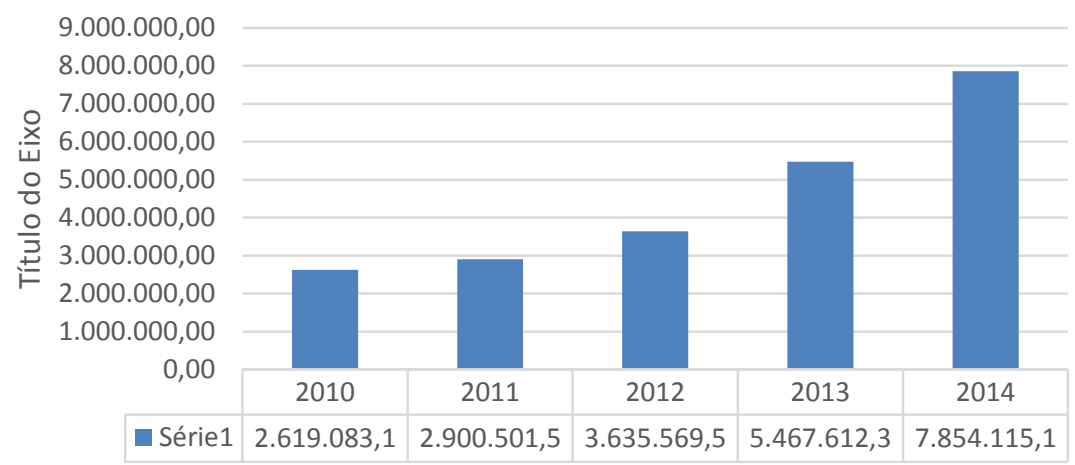

Fonte: Elaborado pelos autores com base no PME/SME 2014

A tabela 6 evidencia que grande parte do recurso destinado à educação infantil está comprometido com o pagamento de salários, embora a maior parte dos recursos é destinado para o pagamento de serviços como "compra de vagas em escolas de Educação Infantil, água, luz, processamento de dados, serviços gráficos, transporte escolar, vigilância, palestrantes, higienização terceirizada, locação de máquinas e equipamentos, serviço de publicidade" (FARROUPILHA, 2015).

Tabela 6 - Composição dos gastos sobre os investimentos totais com Educação Infantil

\begin{tabular}{ccccccc}
\hline Ano & $\begin{array}{c}\text { Salários e } \\
\text { Encargos } \\
\text { MDE }\end{array}$ & $\begin{array}{c}\text { Salários } \\
\text { FUNDEB }\end{array}$ & Equipamentos & $\begin{array}{c}\text { Obras, Reformas } \\
\text { e manutenção }\end{array}$ & $\begin{array}{c}\text { Material de } \\
\text { Consumo }\end{array}$ & $\begin{array}{c}\text { Outros } \\
\text { Serviços* }\end{array}$ \\
$\mathbf{2 0 1 0}$ & $19,3 \%$ & $27,7 \%$ & & $2,0 \%$ & $51,0 \%$ \\
$\mathbf{2 0 1 1}$ & $11,0 \%$ & $36,2 \%$ & & $1,8 \%$ & $51,0 \%$ \\
$\mathbf{2 0 1 2}$ & $9,2 \%$ & $27,6 \%$ & $0,8 \%$ & $1,9 \%$ & $60,5 \%$ \\
$\mathbf{2 0 1 3}$ & $9,4 \%$ & $20,6 \%$ & & & $2,0 \%$ & $68,0 \%$ \\
$\mathbf{2 0 1 4}$ & $5,1 \%$ & $17,7 \%$ & & $8,6 \%$ & $1,8 \%$ & $66,9 \%$ \\
\hline
\end{tabular}

Fonte: PME 2014 - Secretaria Municipal de Educação

Buscando cumprir as metas do PME e das exigências da Lei Federal no. 12.796/2013, foram abertas 21 novas turmas de educação in- 
fantil de 2014 e mais 6 em 2015 (FARROUPILHA, 2015), entretanto, para ampliar o número de matrículas uma das práticas adotadas pelo município é a compra de vagas. A tabela 7 apresenta o histórico de gastos municipais com a compra de vagas na rede privada.

\section{Tabela 7 - Gastos municipais com compra de vagas na rede privada.}

\begin{tabular}{ccc}
\hline Ano & \multicolumn{1}{c}{ Total } & Variação Percentual \\
\hline 2010 & $\mathrm{R} \$ 998.403,75$ & - \\
2011 & $\mathrm{R} \$ 1.100 .388,75$ & $10,21 \%$ \\
2012 & $\mathrm{R} \$ 1.789 .744,27$ & $62,65 \%$ \\
2013 & $\mathrm{R} \$ 3.141 .294,81$ & $75,52 \%$ \\
2014 & $\mathrm{R} \$ 4.619 .331,47$ & $47,05 \%$ \\
\hline
\end{tabular}

Fonte: Elaborado pelos autores com base no PME/SME 2014

A compra de vagas acontece de duas formas: subvenções e compra de vagas em escolas conveniadas. As subvenções até o ano de 2012 representavam o maior volume de gastos na compra de vagas, entretanto a partir de 2013, o município passou a aportar um volume maior de recursos na compra de vagas em escolas conveniadas. Em 2014, 23,7\% do total de recursos foi destinado a subvenções e $76,3 \%$ a compra de vagas em escolas conveniadas.

Outra prática do município estudado para a oferta de vagas na educação infantil é o regime de colaboração com o governo do Estado do Rio Grande do Sul. As escolas estaduais ofertam sua infraestrutura para o atendimento de 180 alunos em nove turmas de Educação Infantil (FARROUPILHA, 2015), entretanto, os professores compõem o quadro de profissionais da Rede Municipal.

A tabela 8 sistematiza os dados sobre o transporte escolar de estudantes de 4 e 5 anos e ensino fundamental. A análise da tabela acima demonstrou que os gastos com o transporte escolar vão muito além dos $\mathrm{R} \$ 200.640,48$ repassados através do PNATE. Ao realizarmos a soma dos recursos do PNATE com os recursos enviados pelo Governo do Estado para o transporte escolar ( $R \$ 231.548,00$ ), constatou-se que o município precisou complementar o transporte escolar com $\mathrm{R} \$ 1.747 .513,41$. 
Tabela 8 - Gastos com transporte escolar

\begin{tabular}{ccc}
\hline Ano & Recurso $(\mathrm{R} \$)$ & Variação Percentual \\
\hline 2010 & $1.599 .045,00$ & - \\
2011 & $2.587 .550,00$ & $61,82 \%$ \\
2012 & $1.855 .568,40$ & $-28,29 \%$ \\
2013 & $2.239 .966,55$ & $20,72 \%$ \\
2014 & $2.179 .701,89$ & $-2,69 \%$ \\
\hline
\end{tabular}

Fonte: PME 2014 - Secretaria Municipal de Educação

Os custos estimados anual por aluno matriculado na rede municipal de Farroupilha/RS passou de $\mathrm{R} \$ 3.668,12$ em 2010 para $\mathrm{R} \$$ $5.979,11$ em 2013. Não foi possível estimar o custo anual do aluno da educação infantil, pois os dados da pré-escola são incluídos nos custos do ensino fundamental.

O custo aluno de 2014, segundo a Secretaria de Educação, ficou em torno de $R \$ 6.820,00$. É interessante notar que mesmo com a ampliação do número de alunos atendidos o seu custo individual também cresceu. Logo, através desse comportamento pode-se inferir que a criação de vagas de pré-escola apresenta um custo elevado, o que acaba aumentando a média de gastos geral.

Desse modo, com o crescimento do custo por aluno e da realização de obras para construção e reformas de salas de aula, houve um significativo aumento no volume de recursos livres investidos:

\section{Tabela 9 - Comparativo da Evolução dos Recurso Livres Investidos}

\begin{tabular}{l|c|c|c|c|}
\hline & $\begin{array}{c}\text { Total de Receitas de Impostos e } \\
\text { Transferências Constitucionais (R\$) }\end{array}$ & $\begin{array}{c}\text { Variação } \\
\text { Percentual }\end{array}$ & $\begin{array}{c}\text { Total de recursos } \\
\text { livres investido (R\$) }\end{array}$ & $\begin{array}{c}\text { Variação } \\
\text { Percentual }\end{array}$ \\
\hline $\mathbf{2 0 1 0}$ & $73.008 .721,97$ & - & $2.908 .999,41$ & - \\
$\mathbf{2 0 1 1}$ & $85.249 .725,61$ & $16,77 \%$ & $3.728 .240,19$ & $28,16 \%$ \\
$\mathbf{2 0 1 2}$ & $95.344 .548,58$ & $11,84 \%$ & $3.961 .448,31$ & $6,26 \%$ \\
$\mathbf{2 0 1 3}$ & $107.464 .635,87$ & $12,71 \%$ & $5.108 .942,84$ & $28,97 \%$ \\
$\mathbf{2 0 1 4}$ & $110.896 .529,74$ & $3,19 \%$ & $7.282 .337,92$ & $42,54 \%$ \\
\hline
\end{tabular}

Fonte: Elaborado pelos autores com base no PME/SME 2014 
Em 2014 houve um aumento no volume de recursos investidos de $\mathrm{R} \$ 2.173 .395,08$ em comparação com o ano anterior. Esse dado comprova que o total de recursos próprios investidos cresceu percentualmente 42,54\%. Enquanto que o crescimento das transferências constitucionais aumentou apenas 3,19\%.

Por fim, o total de recursos destinados à educação no município de Farroupilha/RS passou de $\mathrm{R} \$ 45.385 .573,70$ em 2013 para $\mathrm{R} \$$ $54.217 .470,81$ no ano de 2015. Foram $\mathrm{R} \$ 8.831 .897,11$ a mais, utilizados na política de educação do município, ou 19,5\%.

A pretensão inicial de encontrar o custo total para o Município de Farroupilha/RS se adaptar à Lei Federal no. 12.796/2013 não pode ser calculado porque não foi possível diferenciar os gastos com a pré -escola e os gastos com as creches. Apesar desta limitação, a análise do financiamento da educação infantil no município, permite auferir que os recursos enviados pelo Governo Federal através de transferências constitucionais não foram suficientes. Nos últimos 5 anos, sempre houve o aporte de recursos próprios para o financiamento da educação. No ano de 2014 ele foi ampliado em 42,5\% em relação ao ano anterior, enquanto o volume de transferências do Governo Federal foi ampliado em um percentual menor, de aproximadamente $20 \%$.

Ainda, para cumprir a lei do piso, $97 \%$ dos recursos do FUNDEB são usados para o pagamento da folha dos professores. Assim, o recurso de mais de $R \$ 2,2$ milhões utilizados em construção e reformas de escolas saíram diretamente dos cofres municipais. Além disso, houve um crescimento do gasto com o transporte e a merenda escolar. Uma vez que, foi necessário ao município ampliar o aporte de recursos que complementam estas áreas.

\subsection{Estratégias para a implementação da Lei Federal nº 12.796/2013}

A avalição da implementação da Lei Federal no.12.796/2013 foi realizada a partir a percepção da Secretaria Municipal de Educação, através de entrevista realizada com o gestor do processo de execu- 
ção da política pública de educação infantil no município de Farroupilha, bem como pela percepção da comunidade do município pela análise do Conselho Municipal de Educação, órgão responsável pelo controle das políticas públicas educação municipal.

A gestão da educação infantil passou por uma extensa mudança, a Lei Federal no . 12.796/2013 estabeleceu um prazo de 2 anos para a adequação as suas exigências, porém, acolher crianças de 4 e 5 anos em escolas preparadas para o ensino fundamental exigiu adaptações na rede municipal. Os novos alunos eram muito pequenos e necessitaram de um tratamento peculiar devido às suas especificidades.

Houve um diálogo permanente com o Conselho Municipal de Educação sobre a demanda trazida pela Lei no. 12796/2013. O tema da educação infantil esteve presente na formulação do novo Plano Municipal de Educação, sua meta era atender o disposto em Lei sempre agregando qualidade.

O planejamento para a execução da política de educação infantil iniciou-se logo após a sanção da lei. Inicialmente a preocupação estava direcionada para o diagnóstico da demanda de alunos que deveriam ser atendidos e das modificações necessárias nas escolas para o acolhimento dos novos alunos. Outro importante foca da SME foi direcionado para o planejamento da qualificação dos professores, pois era necessário preparar os professores concursados para alunos de 4 a 5 anos, além disso, foi imprescindível contratar novos professores e prepará-los para atenderem ao padrão de qualidade pretendido pela Secretaria.

O mapeamento das demandas por educação infantil por bairros no município foi estimado com o auxílio da Secretaria Municipal de Saúde, através do mapeamento das carteirinhas de vacinação. Desse modo, estimou-se o número de crianças de 4 e 5 anos em cada bairro da cidade, porém, este número sofreu oscilações devido a recepção de fluxos migratórios, característica no município de Farroupilha/RS.

O critério para a decisão sobre quais escolas receberiam as obras de reforma das salas de aula foi o número de alunos que deveriam ser atendidos, ou seja, as escolas que receberiam mais alunos seriam 
contempladas com obras. Sobre os recursos recebidos pelo Governo Federal apresentados pelo entrevistador, a Gestora informou que os valores repassados pelo Programa Pró-Infância são referentes à construção de duas novas creches para o atendimento da demanda de crianças de 4 meses a 3 anos de idade. Desse modo, o aumento total na quantidade de transferências, foi utilizado na contratação de professores, no dissídio dos professores e na manutenção da SME.

Além disso, como o repasse do FUNDEB é realizado através do número de alunos matriculados no ano anterior, toda a demanda de alunos de 4 e 5 anos atendida no ano de 2014 somente será computada para o repasse do FUNDEB de 2015.

Mesmo diante das dificuldades financeiras enfrentadas, a meta de colocar $100 \%$ das crianças de 4 e 5 anos na rede de educação infantil foi concluída antecipadamente. O ano letivo de 2015 iniciou com 1020 alunos dessa faixa etária matriculados na rede pública municipal. Para efetivar a política pública de educação infantil no município, houve um forte investimento proveniente dos cofres municipais, cerca de $R \$ 2,2$ milhões de reais foram utilizados na construção, reformas e mobília de 13 salas de aula equipadas com banheiros adequados para crianças de 4 e 5 anos. São 63 turmas de pré-escola na rede municipal, sendo que 27 delas são novas. Elas são atendidas por 53 professores titulares, sendo que 14 deles foram chamados através de um novo concurso público para professores de Educação Infantil e Pré-Escola.

A alimentação e o transporte escolar estão integradas a escolas de ensino fundamental, a merenda escolar é a mesma e segundo a nutricionista do município ela é adequada aos parâmetros nutricionais das crianças de 4 e 5 anos. O transporte escolar é ofertado para crianças residentes no interior do município e para aquelas que não conseguiram vaga próxima a sua residência. Porém, a gestora ressalta que os valores recebidos pelo PNAE e PNATE não são suficientes para o atendimento das demandas, a SME realiza a complementação.

A secretária municipal de Educação avalia como positivo o processo de efetivação da Lei Federal no. 12.796/2013 em Farroupilha/ 
RS. Os desafios foram superados e a meta foi cumprida antes do prazo estabelecido. Entretanto, a continuidade da política de educação infantil depende de recursos financeiros, e o aporte feito pelo município é que tem garantido à execução da política. Na avaliação da gestão municipal a União deve aumentar os investimentos, principalmente se forem confirmados o aumento do volume de repasses devido aos royalties do pré-sal.

Na percepção do Conselho Municipal de Educação, a Lei Federal no. 12.796/2013 possibilitou um grande avanço no atendimento de crianças de 4 e 5 anos. O Conselho Municipal de Educação foi ativo no processo de elaboração do novo Plano Municipal de Educação que inclui entre suas prioridades universalizar, até 2016, a Educação Infantil na pré-escola para as crianças de 4 a 5 anos de idade e ampliar a oferta de Educação Infantil em creches de forma a atender, no mínimo, 50\% (cinquenta por cento) das crianças de até 3 (três) anos até o final da vigência do PNE. Para o atendimento das metas acima referidas, foram estabelecidas 30 estratégias a serem implementadas.

O Conselho Municipal de Educação aprovou a resolução nํ․ 01/2014 que tem como objetivo sua participação ativa no recadastramento das Escolas de Ensino Fundamental para integrá-las ao Sistema Municipal de Ensino e autorizá-las a desenvolver suas atividades. Desse modo, as escolas passaram por vistoria e acompanhamento visando garantir a qualidade de sua estrutura física. Antes dessa resolução, a responsabilidade cabia ao Conselho Estadual de Educação, porém, devido às suas limitações, ele não executava a tarefa.

A partir das vistorias realizadas nas escolas, CME realizou um diagnóstico da situação das Escolas de Ensino Fundamental e suas demandas. O CME e a gestão da Secretaria da Educação, consideram os recursos escassos, dado que as transferências de recursos do Governo Federal para educação através de fundos e programas não são suficientes. As mudanças necessárias para o atendimento das demandas de educação infantil possuem um custo maior do que o custeio do ensino fundamental. 
Por isso, é necessário o aumento do investimento em educação para que os municípios brasileiros possam cumprir o disposto em Lei. O atual modelo de colaboração entre os entes federativos está onerando os municípios, as administrações municipais fazem manobras financeiras para garantir os recursos para a educação.

Os pontos positivos identificados pelo órgão de controle social na execução das políticas de educação foram: a) a extensão da rede da escolar que tem a capacidade de atender todos os as crianças de $4 \mathrm{e}$ 5 anos na pré-escola; b) a boa condução por parte da Secretaria Municipal de Educação das mudanças necessárias para a implementação da Lei Federal no. 12.796/2013, o que permite que as metas sejam alcançadas; c) a realização de um efetivo planejamento, através do PME, para a realização das mudanças necessárias para a adequação do município à Lei.

\section{Considerações Finais}

Este estudo buscou compreender a implementação da Lei Federal no. 12.796/2013, que determinou a obrigatoriedade da matrícula de todas as crianças de 4 e 5 anos na rede de ensino básico, a partir do estudo de caso da gestão da educação infantil no município de Farroupilha.

Desde o ano de 2006 ocorrem mudanças graduais que determinaram a educação infantil como direito social e visaram ampliar o número de alunos matriculados nos municípios brasileiros. A aprovação da Lei Federal no. 12.796/2013 foi determinante uma vez que determinou a obrigatoriedade da matrícula de crianças de 4 e 5 anos na rede pública municipal de ensino. A educação infantil foi incluída no Plano Nacional de Educação e posteriormente nos Planos Municipais de Educação.

A análise da legislação sobre o financiamento da educação revelou que o modelo de vinculação de recursos que vigora desde 1996 com o FUNDEF foi ampliado através da ampliação de tributos do FUNDEB em 2006. Ainda, a abrangência de financiamento do 
novo fundo passou a considerar a educação infantil. Assim como o FUNDEB, outros programas de financiamento da educação como o Salário Educação, PNAE e PNATE também foram ampliados para o atendimento da educação infantil. Por conseguinte, houve uma complementaridade entre as mudanças de ampliação do escopo da educação infantil e a política de financiamento da educação.

Porém, através da análise do caso escolhido verificou-se que este regime de colaboração é deficitário para os municípios. A análise da receita realizada durante a pesquisa demonstrou que entre o ano de 2013 e 2014 houve um aumento de $R \$$ 4,7 milhões nos repasses, grande parte graças ao FUNDEB. Porém, cerca de 97\% do total de recursos do fundo foram utilizados para o pagamento dos docentes. Assim, foi necessário um aporte de $\mathrm{R} \$ 2,2$ milhões do ente municipal para a construção e reformas de salas de aula e outras dependências escolares necessárias para o correto atendimento dos alunos de 4 e 5 anos.

O município de Farroupilha/RS adequou-se a todas as normas legais referentes à educação. Todas as mudanças de legislação referentes ao ensino foram cumpridas, a Lei Federal no . 11.738/2008 (Lei do Piso), a Lei Federal no. 11.274/2006 (ensino fundamental de 9 anos) e, a Lei Federal no. 12.796/2013. Ainda, o município caminha para cumprir a meta do atendimento de crianças de 0 a 3 anos antes do prazo estabelecido.

Para cumprir todas estas etapas, o percentual de investimento através de recursos próprios do município continua a crescer, contudo, o aumento das transferências via governo federal não acompanha os percentuais do município. Portanto, fica claro que para cumprir com a meta de universalizar o acesso das crianças de 4 e 5 anos na Pré-Escola foi necessário o esforço financeiro por parte do município estudado.

Assim, percebe-se que somente aqueles municípios que tiverem receitas próprias poderão cumprir a lei. No caso estudado há 5 anos o percentual de investimento em educação básica sempre esteve acima de $31 \%$, superando a obrigatoriedade constitucional de 25\%. 
Entretanto, esta não é a realidade da maioria dos municípios brasileiros, pois muitos são dependentes das transferências constitucionais para a implementação das suas políticas públicas de educação. Neste sentido, há a necessidade de que todos os entes federados cumpram suas obrigações constitucionais para que possamos ter uma implementação mais efetiva e equânime das políticas de educação num país tão desigual.

\section{Referências}

BARROS, Fabiana Pereira; MOREIRA, J.A.S. As políticas para o financiamento da educação básica pública no Brasil. Revista Percurso (Online), v. 4, p. 193-207, 2012.

BRASIL. Constituição Federal de 1988. Disponível em: <http://www. planalto.gov.br/ccivil_03/constituicao/constituicaocompilado.htm>.Acesso em: 05 de maio de 2015.

Emenda Constitucional no. 14, 12 de setembro de 1996. Modifica os arts. 34, 208, 211 e 212 da Constituição Federal e dá nova redação ao art. 60 do Ato das Disposições constitucionais Transitórias. Disponível em <http://www.planalto.gov.br/ccivil 03/constituicao/Emendas/Emc/ emc14.htm>. Acesso em 05 jun. 2015.

Emenda Constitucional no 53, 19 de dezembro de 2006. Dá nova redação aos arts. 7ㅇ 23, 30, 206, 208, 211 e 212 da Constituição Federal e ao art. 60 do Ato das Disposições Constitucionais Transitórias. Disponível em <http://www.planalto.gov.br/ccivil 03/constituicao/Emendas/ Emc/emc53.htm>. Acesso em 05 de maio de 2015.

Medida Provisória 1.784 de 14 de dezembro de 1998. Dispõe sobre o repasse de recursos financeiros do Programa Nacional de Alimentação Escolar, institui o Programa Dinheiro Direto na Escola, e dá outras providências.Disponível em <http://www. planalto.gov.br/ccivil 03/mpv/ Antigas/1784.htm>. Acesso em 10 de jun. 2015.

Decreto no $\mathbf{3 7 . 1 0 6}$ de 31 de março de 1955. Institui a companhia da Merenda Escolar.Disponível em <http://www2.camara.leg.br/legin/fed/ decret/1950-1959/decreto-37106-31-marco-1955-332702-publicacaooriginal-1-pe.html>. Acesso em 05 maio 2015. 
Decreto no $\mathbf{6 . 0 0 3}$ de 28 de dezembro de 2006. Regulamenta a arrecadação, a fiscalização e a cobrança da contribuição social do salário -educação, a que se referem o art. 212, § 5, da Constituição, e as Leis nos 9.424 , de 24 de dezembro de 1996, e 9.766, de 18 de dezembro de 1998, e dá outras providências. Disponível em <http://www.planalto.gov. br/ccivil_03/_Ato2004-006/2006/Decreto/D6003.htm $\geq$ Acesso em 15 abr. 2015.

Lei no 4.440 de 27 de outubro de 1964. Institui o Salário-Educação e dá outras providências. Disponível em <http://www.planalto.gov.br/Ccivil 03/Leis/1950-1969/L4440.htm>. Acesso em 05 jun. 2015.

Lei no $\mathbf{5 . 5 3 7}$ de 21 de novembro de 1968. Cria o Instituto Nacional de Desenvolvimento da Educação e Pesquisa (INDEP), e dá outras providências. Disponível em <http://www.planalto.gov.br/ccivil 03/Leis/L5537. htm>. Acesso em 19 maio 2015.

Lei no 7.348 de 24 de julho de 1985. Dispõe sobre a execução do $\S 4^{\circ}$ do art. 176 da Constituição Federal, e dá outras providências. Disponível em <http://www.planalto.gov.br/ccivil 03/leis/1980-1988/L7348. htm>. Acesso em 05 maio 2015.

Lei $\mathbf{8 . 9 1 3}$ de 12 de julho de 1994. Dispõe sobre a municipalização da merenda escolar. Disponível em < $<$ http://www.planalto.gov.br/ccivil 03/ Leis/L8913.htm>. Acesso em 10 maio 2015.

Lei no 9.394 de 20 de dezembro de 1996. Estabelece as diretrizes

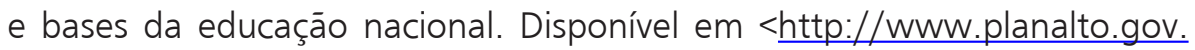
br/ccivil 03/leis/l9394.htm>. Acesso em 20 maio 2015.

Lei no 9.424 de 24 de dezembro de 1996. Dispõe sobre o Fundo de Manutenção e Desenvolvimento do Ensino Fundamental e de Valorização do Magistério, na forma prevista no art. 60, § 70, do Ato das Disposições Constitucionais Transitórias, e dá outras providências. Disponível em <http://www. planalto.gov.br/ccivil 03/leis/19424.htm>. Acesso em 10 jun. 2015.

Lei no 9.766 de 18 de dezembro de 1998. Altera a legislação que rege o Salário-Educação, e dá outras providências. Disponível em $<\underline{\text { http: } / /}$ www.planalto.gov.br/ccivil 03/leis/L9766.htm>. Acesso em 10 jun. 2015.

Lei $\mathbf{n} \mathbf{0} \mathbf{1 0 . 1 7 2}$ de 9 de janeiro de 2001. Aprova o Plano Nacional de Educação e dá outras providências. Disponível em: <http://www.planalto. gov.br/ccivil 03/leis/leis 2001/l10172.htm>. Acesso em 05 maio 2015. 
Lei 10.709 de 31 de julho de 2003. Acrescenta incisos aos arts. 10 e 11 da Lei n-9.394, de 20 de dezembro de 1996, que estabelece as diretrizes e bases da educação nacional e dá outras providências. Disponível em: <http://www.planalto.gov.br/ccivil 03/leis/2003/110.709.htm>. Acesso em 05 jun 2015.

Lei $\mathbf{n} \mathbf{0} \mathbf{1 0 . 8 3 2}$ de 29 de dezembro de 2003. Altera o $\S 1^{\circ}$ e 0 seu inciso II do art. 15 da Lei no 9.424, de 24 de dezembro de 1996, e o art. 2ำ da Lei $\mathrm{n}^{\circ} 9.766$, de 18 de dezembro de 1998, que dispõem sobre o Salário-Educação. Disponível em <http://www.planalto.gov.br/ccivil 03/ leis/2003/|10.832.htm>. Acesso em 25 abr 2015.

Lei $\mathbf{1 0 . 8 8 0}$ de 9 de junho de 2004. Institui o Programa Nacional de Apoio ao Transporte do Escolar - PNATE e o Programa de Apoio aos Sistemas de Ensino para Atendimento à Educação de Jovens e Adultos, dispõe sobre o repasse de recursos financeiros do Programa Brasil Alfabetizado, altera o art. 4º da Lei $n^{\circ} 9.424$, de 24 de dezembro de 1996, e dá outras providências. Disponível em <http://www.planalto.gov.br/ccivil 03/ ato20042006/2004/lei//10.880.htm>. Acesso em 15 jun 2015.

Lei no $\mathbf{1 1 . 1 1 4}$ de 16 de maio de 2005. Disponível em: http:// www.planalto.gov.br/ccivil_03/_Ato2004-2006/2005/Lei/L11114.htm. Acesso em 29 abr. 2015.

Lei $\mathbf{n} \mathbf{0} \mathbf{1 1 . 2 7 4}$ de 6 de fevereiro de 2006. Altera a redação dos arts. 29, 30, 32 e 87 da Lei no 9.394, de 20 de dezembro de 1996, que estabelece as diretrizes e bases da educação nacional, dispondo sobre a duração de 9 (nove) anos para o ensino fundamental, com matrícula obrigatória a partir dos 6 (seis) anos de idade Disponível em: http://www.planalto.gov.br/ ccivil_03/_Ato2004-2006/2006/Lei/l11274.htm Acesso em 29 abr. 2015.

Lei no 11.494 de 20 de junho de 2007. Regulamenta o Fundo de Manutenção e Desenvolvimento da Educação Básica e de Valorização dos Profissionais da Educação - FUNDEB Disponível em: <http://www.planalto. gov.br/ccivil_03/_ato2007-2010/2007/lei/l11494.htm> Acesso em 29 abr. 2015.

Lei no 12.801 de 24 de abril de 2013. Dispõe sobre o apoio técnico e financeiro da União aos entes federados no âmbito do Pacto Nacional pela Alfabetização na Idade Certa. Disponível em: <http://www.planalto. gov.br/ccivil_03/_Ato2011-2014/2013/Lei/L12801.htm> Acesso em 10 maio 2015. 
Lei $\mathbf{n} \mathbf{0} \mathbf{1 3 . 0 0 5}$ de 25 de junho de 2014. Aprova o Plano Nacional de Educação - PNE e dá outras providências. Disponível em: <http://www. planalto.gov.br/ccivil_03/_Ato2011-2014/2014/Lei/L13005.htm>_Acesso em 10 jun. 2015.

Ministério da Educação. 12.801 Resolução no6 de 24 de abril de 2007. Disponível em: <http://portal.mec.gov.br/arquivos/pdf/resolucao_ n6_240407_proinfancia_medida18.pdf.pdf.>. Acesso em 10 abr. 2015.

CRUZ, Rosana Evangelista da. Pacto federativo e financiamento da educação: a função supletiva e redistributiva da União - o FNDE em destaque. 2009. Tese (Doutorado em Educação) - Faculdade de Educação, Universidade de São Paulo, São Paulo, 2009. Disponível em: <http://www.teses. usp.br/teses/disponiveis/48/48134/tde-11122009-101928/> Acesso em 10 abr. 2015.

CURY, Carlos Roberto Jamil. A Educação Básica no Brasil. Educação e Sociedade, v. 23, p. 169-201, 2002.

FARENZENA, N.; LUCE, M. B. Financiamento da educação e responsabilidades federativas: 25 anos de agenda constituinte. Revista Brasileira de Política e Administração da Educação, v. 29, p. 263-281, 2013.

FARROUPILHA. Lei no 3224 de 19 de dezembro de 2006. Aprova o Plano Municipal de Educação, e dá outras providências. Disponível em: $<$ http://leis.farroupilha.rs.gov.br:8080/docsweb/Controlador?submit=Editar\&id=6984>. Acesso em 10 abr. 2015.

Lei no 3.282 de10 de Julho de 2007. Dispõe sobre a criação do Conselho Municipal de Acompanhamento e Controle Social do Fundo de Manutenção e Desenvolvimento da Educação Básica e de Valorização dos Profissionais da Educação - Conselho do FUNDEB. Disponível em: $<$ http://leis.farroupilha.rs.gov.br:8080/docsweb/Controlador?submit=Editar\&id=8801>. Acesso em 10 abr. 2015.

MACHADO, Maria Goreti Farias. A proposta de FUNDEB do Executivo federal: interlocuções na formulação da política - recorte de pesquisa. In: Il semana de educação e pesquisa, 2006, Porto alegre. Centro Universitário Ritter dos reis. Porto alegre: Uniritter, 2006.

OLIVEIRA, Rosimar de Fátima; TEIXEIRA, Beatriz de Basto. As políticas de financiamento da educação na última década: do FUNDEF ao FUNDEB. In: IV Simpósio Internacional O Estado e as Políticas Educacionais no Tempo Presente, 2008, Uberlândia. Anais do IV Simpósio Internacional O 
Estado e as Políticas Educacionais no Tempo Presente. Uberlândia: UFU, 2008. p. 1-14.

SENA, Paulo. O financiamento da educação básica como política pública. Revista Brasileira de Política e Administração da Educação - v.26, n.3, p. 497-514, set./dez. 2010

VIEIRA, S. L.; FARIAS, I. M. S. Política Educacional no Brasil: introdução histórica. Brasília: Liber Livro, 2007.

YIN, Robert K; Estudo de Caso: Planejamento e Métodos. Porto Alegre: Artmed Editora S.A., 2005. 


\title{
O Alinhamento do Planejamento Governamental (PPA) Federal com o Municipal (PPAS) de alguns municípios do RS
}

\author{
Fábio Ricardo Cardoso Magalhães ${ }^{1}$ \\ Wendy Beatriz Witt Haddad Carraro²
}

\section{Introdução}

Um estudo inédito de 2006 a 2010 da Federação das Indústrias do Rio de Janeiro (ESTUDO DA FIRJAN..., 2012) sobre a gestão fiscal dos municípios brasileiros aponta que "83\% dos municípios não se sustentam". Ao comentar o estudo, José Carlos Rassier, Secretário Geral da Associação Brasileira dos Municípios, disse que toda a receita arrecadada no Brasil de $60 \%$ a $65 \%$ são da União, 20\% a 25\% são dos estados e $17 \%$ a $19 \%$ são dos municípios. Este cenário apresentado nos mostra que os municípios possuem uma alta dependência das esferas estadual e federal para comporem seus orçamentos.

As esferas governamentais previstas em nossa Constituição Federal (BRASIL, 1988) - federal, estadual e municipal - têm como uma das conquistas a ampla redistribuição de recursos orçamentários, descentralização fiscal, elevação da capacidade fiscal própria e disponível (via transferências) nas esferas subnacionais. As transferências de

Especialista em Gestão Pública Municipal pela Universidade Federal do Rio Grande do Sul

Dra. Em Economia. Professora do Departamento de Ciências Contábeis e Atuariais da UFRGS. 
recursos entre as esferas governamentais são realizadas através de transferências legais, programas e convênios firmados, que definem objetivos, metas, forma de execução, monitoramento, prestação de contas e avaliação. São resultados da articulação e integração intergovernamental da administração e gestão pública sistêmica.

Os municípios, para melhorarem sua eficiência na gestão fiscal, têm autonomia para inovar e buscar caminhos, com o objetivo de vencer os desafios na busca do aumento da arrecadação de recursos públicos. Essa alternativa exige que as gestões públicas reforcem sua capacidade de gestão que envolve o ciclo de planejamento, elaboração de projetos, compras, contratações, execução, monitoramento e avaliação.

O alinhamento estratégico, para Henderson e Venkatraman (1993), corresponde à adequação planejada e à integração funcional entre os ambientes externos (mercado, política, fornecedores, etc.) e internos (estrutura administrativa e recurso financeiros, tecnológicos e humanos) para desenvolver as competências e maximizar o desempenho organizacional.

A justificativa social para este trabalho está em demonstrar aos gestores públicos municipais que uma das alternativas técnicas para melhorar a situação da gestão fiscal de seu município seria melhorar e qualificar as relações com o governo federal, através de um alinhamento de planejamento governamental, para trazer resultados melhores à captação de recursos. O alto nível de dependência dos municípios com relação às transferências de recursos e a dificuldade de promover o desenvolvimento municipal direciona a atenção dos atuais gestores à maior fonte arrecadadora do país: a União.

Portanto, esta forma de gestão fiscal municipal brasileira e o método de planejamento governamental adotado pela maior fonte arrecadadora do país, geram a seguinte questão problema: o alinhamento técnico de planejamento da esfera municipal com a federal promove uma maior distribuição de recursos aos municípios? Para respondê-la, o objetivo geral da pesquisa é verificar o alinhamento técnico do planejamento governamental da esfera federal (BRASIL, 
2011) com a esfera municipal (BRASIL, 2013) de alguns municípios do Estado do Rio Grande do Sul (tais como São Francisco de Paula, Cambará, Taquara, Parobé, Pelotas e Canoas), através da ferramenta Technology Roadmapping (TRM).

Este trabalho está estruturado da seguinte forma: além da introdução são abordados os princípios, conceitos e a estruturação do planejamento governamental federal, explica a metodologia Technology Roadmapping (TRM) no âmbito privado e sua adequação ao público. Na sequência são elaborados o mapa (TRM) de alinhamento técnico de planejamento, os quadros comparativos de pontuação e o indicador de transferências de recursos federais. Encerra-se com a análise, seguida das considerações finais.

\section{2 - Planejamento do Governo Federal e Municipal}

Nesta seção apresenta-se a nova metodologia de planejamento governamental adotada pelo governo federal a partir de 2012, a base legal para elaboração do Plano Plurianual (PPA), sua estrutura e princípios que servirão para construir o mapa e os quadros comparativos com a TRMe a importância do planejamento para a governabilidade.

\section{1 - Planejamento Governamental no Brasil 2012-2015}

De acordo com Brasil (2011), esta nova maneira de pensar e planejar a gestão governamental tem como meta dar mais clareza e objetividade à abordagem dos grandes problemas, programas e objetivos a ser priorizados. Estabelece critérios para alocação dos orçamentos anuais e define diretrizes do sistema de gestão do planejamento de acordo com o artigo 165 da Constituição Federal (BRASIL, 1988) que instituiu o Plano Plurianual para todas as esferas de governo (federal, estadual e municipal).

O Ministério do Planejamento, Orçamento e Gestão (MPOG) editou as orientações para elaboração do Plano Plurianual 2012-2015 (BRASIL, 2011), apresentou nesse as alterações na estrutura do PPA 
com base em novos conceitos e princípios, e a natureza de "plano" preservando as diferenças essenciais relativas ao orçamento anual.

Em 2013, após a adoção do novo modelo do PPA federal de 2012-2015, o governo federal lançou o Programa de Apoio à Elaboração e Implementação dos PPAs Municipais - 2014-2017 (BRASIL, 2013). O intuito era orientar e estimular para que os novos gestores municipais escolhidos nas eleições de 2012,pudessem adotar a mesma modelagem de planejamento governamental. Os prefeitos eleitos em 2012 tiveram prazo até 31 de agosto de 2013 para elaborarem seus PPAs, ou seja, seu planejamento para os 4 anos seguintes à sua posse.

A proposta era alinhar os objetivos e apoiar a elaboração dos Planos Plurianuais Municipais 2013-2017 (BRASIL, 2013). Assim, esses Planos se transformariam em uma janela de oportunidades para que os governos locais mobilizem as forças vivas da cidade em direção a um projeto de futuro. O desafio era construir coletivamente agendas de desenvolvimento territoriais integradas, por via da cooperação federativa, com as estratégias estadual e nacional em cada município.

O PPA é um instrumento de planejamento estratégico para o poder público, isto é, serve para organizar os recursos, as energias do governo e da sociedade em direção à uma visão de futuro e um cenário em médio prazo (BRASIL, 2012). O PPA seria o documento conectado ao plano de governo dos candidatos à eleição municipal, nele constaria a visão estratégica de cada um, além de suas propostas de mandato. Duas outras leis estão intimamente associadas ao PPA: Lei de Diretrizes orçamentárias (LDO) e a Lei do Orçamento Anual (LOA). Definem-se essas Leis da seguinte forma (BRASIL, 2012).

O PPA organiza toda a matriz de aplicação dos recursos públicos disponíveis, que impacta sobre toda a gestão do mandato de um gestor. Esse plano deve ser a ferramenta que consolida uma visão estratégica com base na participação da comunidade, da força de trabalho público, nas demandas prioritárias integrando todas as forças de articulação e interesses da maioria da população. 


\section{2 - Parâmetros da estrutura e princípios do Planejamento Governamental}

Os atributos do planejamento serão utilizados como parâmetros na análise do planejamento do PPA e como base para elaboração do mapa TRM/quadros. Esta visão conceitual permite identificar uma sequência lógica do caminho a ser percorrido desde a ideia proposta até a execução e consumação da ação de uma política pública. Em Brasil (2011, p. 12) se encontra a noção de um novo arranjo no formato que as estruturas organizacionais públicas deveriam ser dispostas para exercer a macro função do planejamento governamental.

Essas dimensões possuem uma vinculação com os conceitos de efetividade, eficácia e eficiência e deixam clara a responsabilidade e o papel de cada uma no planejamento governamental. Para Marinho e Façanha (2001), no uso corrente, a efetividade diz respeito à capacidade de se promover resultados pretendidos, os quais sós serão contemplados quando os gestores tiverem a visão estratégica de sua gestão. Por isso que a efetividade está vinculada à Dimensão Estratégica.

Meirelles (2002, p. 94) destaca que o Princípio da Eficiência exige que a atividade administrativa seja exercida com presteza, perfeição e rendimento funcional. Os resultados eficientes estão vinculados à Dimensão Operacional, mas dependem diretamente das ações estratégicas e táticas dos gestores. Sem estas ações anteriores o produto ou o serviço não chegaria à população.

Chiavenato (1994, p.70) estabelece que:

[...] quando ele utiliza estes instrumentos fornecidos por aqueles que executam para avaliar o alcance dos resultados, isto é, para verificar se as coisas bem feitas são as que realmente deveriam ser feitas, então ele está se voltando para a eficácia (alcance dos objetivos através dos recursos disponíveis.

Portanto, a eficácia que está vinculada à dimensão tática, exige a dedicação exclusiva de pessoas capacitadas e investidas da função de planejamento. Esta dimensão seria o elo decodificador entre a di- 
mensão estratégica e a operacional. A definição dos parâmetros para realização da analise foi baseada no esquema do desenho básico de um programa do PPA e demonstra o caminho que foi adotado, de acordo com Brasil (2013, p. 44)

A descrição conceitual dos parâmetros de análise, segundo Brasil (2011, 2013), está no Quadro 1.

\section{Quadro 1 - Descrição Conceitual dos Parâmetros de Análise}

\begin{tabular}{|l|l|l|l|}
\hline № & Parâmetros & \multicolumn{1}{c|}{ Descrição Conceitual } \\
\hline 1. & $\begin{array}{l}\text { Dimensão } \\
\text { Estratégica }\end{array}$ & $\begin{array}{l}\text { É orientação construída com base na visão de futuro, } \\
\text { com um diagnóstico socioeconômico, e macro desafios das } \\
\text { demandas e prioridades captadas junto à comunidade; } \\
\text { Esta dimensão envolve as pessoas da cúpula governamental (di- } \\
\text { mensão estratégica - efetividade), os técnicos de planejamento (di- } \\
\text { mensão tática - eficácia), as lideranças comunitárias e a população, } \\
\text { que com grande esforço de coordenação, organização e integra- } \\
\text { ção, através de reunios e audiências públicas do PPA. }\end{array}$ \\
\hline Programa & $\begin{array}{l}\text { - Representa, no PPA, a agenda do governo organizada pelos temas } \\
\text { das políticas públicas e orienta a ação governamental; }\end{array}$ \\
\hline Temático & $\begin{array}{l}\text { Envolve os desafios e organiza a gestão, o monitoramento, a ava- } \\
\text { liação, as transversalidades, as multissetoarialidades e as territo- } \\
\text { rialidades; }\end{array}$ \\
\hline Na prática, dá visibilidade aos problemas e às ações corretivas de \\
uma gestão pública, separando e destacando-os das ações de ro- \\
tina de gestão.
\end{tabular}




\begin{tabular}{|c|c|c|}
\hline 6. & Iniciativas & $\begin{array}{l}\text { - Declaram as entregas à sociedade de bens e serviços, resultantes } \\
\text { da coordenação de ações orçamentárias e outras ações institucio- } \\
\text { nais e normativas, bem como da pactuação entre entes federados, } \\
\text { como o Estado e a sociedade e da integração de políticas públicas. }\end{array}$ \\
\hline 7. & $\begin{array}{l}\text { Participação } \\
\text { Social }\end{array}$ & $\begin{array}{l}\text { - A participação social qualifica tecnicamente o planejamento, pois } \\
\text { é considerado como importante instrumento de interação entre o } \\
\text { Estado e o cidadão, com vistas à efetividade das políticas públicas; } \\
\text { - Consistem na realização de audiências públicas ou de reuniões } \\
\text { com o objetivo de receber sugestões, ideias e prioridades para a } \\
\text { ação do governo. }\end{array}$ \\
\hline 8. & $\begin{array}{l}\text { Dimensão } \\
\text { Territorial }\end{array}$ & $\begin{array}{l}\text { - O conhecimento e a análise dos limites, potencialidades e peculiari- } \\
\text { dades do município com a incorporação da dimensão territorial, na } \\
\text { orientação da alocação dos investimentos, qualificam e resultam } \\
\text { em efetividade na aplicação dos recursos. }\end{array}$ \\
\hline 9. & $\begin{array}{l}\text { Conhecimen- } \\
\text { to de Políti- } \\
\text { cas Públicas }\end{array}$ & $\begin{array}{l}\text { - A valorização do conhecimento sobre as políticas públicas na ela- } \\
\text { boração dos Programas Temáticos seleciona e direciona todas as } \\
\text { ações para os problemas; } \\
\text { - Este parâmetro será avaliado pelo o uso, ou não, da forma de } \\
\text { construção dos Programas Temáticos. }\end{array}$ \\
\hline 10. & $\begin{array}{l}\text { Execução } \\
\text { das Políticas } \\
\text { Públicas }\end{array}$ & $\begin{array}{l}\text { - A responsabilidade e o compromisso com foco na execução das } \\
\text { políticas públicas, reforça a necessidade de realizar as iniciativas } \\
\text { definidas no Plano; } \\
\text { - Assim, as ações são concretizadas. Este parâmetro será avaliado } \\
\text { pelo registro, ou não, no Plano de políticas públicas. }\end{array}$ \\
\hline 11. & Parcerias & $\begin{array}{l}\text { - Identificar, interagir e se integrar visando o estabelecimento de } \\
\text { parcerias com os Estados, os Municípios, a iniciativa privada e a } \\
\text { sociedade civil, promove a União de esforços para o alcance de } \\
\text { objetivos comuns. }\end{array}$ \\
\hline 12. & $\begin{array}{l}\text { Foco na Efeti- } \\
\text { vidade }\end{array}$ & $\begin{array}{l}\text { - Realizar uma gestão com foco na efetividade, entendida como de- } \\
\text { sempenho quanto à transformação de uma realidade, que aponta } \\
\text { mudanças socioeconômicas, ambientais ou }\end{array}$ \\
\hline 13. & $\begin{array}{l}\text { Foco na } \\
\text { Eficácia }\end{array}$ & $\begin{array}{l}\text { - Possuir e constituir equipe com foco na eficácia, relacionada com a } \\
\text { dimensão tática do Plano, entendida como a incorporação de novos } \\
\text { valores às políticas públicas e à entrega de bens e serviços ao público } \\
\text { correto, de forma adequada, no tempo e no lugar apropriado; }\end{array}$ \\
\hline 14. & $\begin{array}{l}\text { Diretrizes } \\
\text { para Aloca- } \\
\text { ção Orça- } \\
\text { mentária }\end{array}$ & $\begin{array}{l}\text { - Possuir uma visão estratégica facilita a emissão de diretrizes para } \\
\text { a alocação orçamentária mais eficiente e para a priorização dos } \\
\text { investimentos. }\end{array}$ \\
\hline
\end{tabular}

Fonte: BRASIL (2011) e BRASIL (2013)

A descrição conceitual dos parâmetros de análise, conforme apresentado, permite uma melhor compreensão e foco quanto aos conceitos de efetividade, eficácia e eficiência que se espera no processo de planejamento governamental. 


\section{3 - O planejamento governamental e a governabilidade}

Segundo Dagnino (2009), o conceito de governabilidade "pode ser entendido através de uma ferramenta simples e muito útil para a análise de viabilidade política de projetos e de ações de governo: o Triângulo de Governo.

O Projeto de Governo consiste nos objetivos traçados com base nas demandas da população que elegeu a gestão. É a proposta de mudança ou a transformação para alterar o cenário atual. O projeto de governo começa no Plano de Governo que fornecerá as diretrizes para a elaboração do PPA.

O Apoio Político é a crença e o crédito ao gestor eleito para que implemente as mudanças propostas durante a campanha eleitoral. A tendência é uma gestão começar com apoio alto e o perder com o tempo.

A capacidade de governar, para Dagnino (2009), está relacionada à experiência de gestão, aos métodos de trabalho, à organização interna, às habilidades pessoais, ao pessoal capacitado, à capacidade de formar opinião, de gerenciar ou de coordenar processos de trabalho, e à comunicação e mobilização de apoio. A tendência é que a capacidade de governar aumente no decorrer da gestão. Dagnino (2009) salienta que a governabilidade de uma gestão depende dessas variáveis e define em uma frase esta afirmação:

A Capacidade de Governo (ou governança) é o recurso cognitivo (saber governar) com o qual conta a equipe de governo e deriva desse conjunto de fatores.

Portanto, a governabilidade passa pela forte atuação da macro função planejamento, sendo de grande importância e determinante para o sucesso ou para o fracasso de uma gestão pública.

\section{3 - Metodologia Technology Roadmapping (TRM)}

O TRM é um método de gerenciamento utilizado para suportar o planejamento estratégico tecnológico em empresas coorporativas. Ele auxilia na estruturação, no desdobramento, na comunicação e no 
estabelecimento da visão de futuro da organização e na sua integração com os planos de mercado, produto e tecnologia (PHAAL, et al, 2001b). Em resumo, é um método gráfico que permite estabelecer uma visão da estratégica tecnológica para criar decisões em um mercado competitivo.

Há várias maneiras de elaborar um roadmap, mas Phaal et al (2004) propõem o T-Plan como guia para elaboração do TRM. Nesta pesquisa ter-se-á como foco somente o planejamento estratégico e a análise de mercado adequado ao ambiente governamental, portanto, não será desenvolvido nenhum produto ou tecnologia.

Neste artigo não serão executados os workshops (mercado, produto e tecnologia) proposto por Phaal et al (2004) no processo de elaboração tipo T-Plan, mas visualizar-se-á se o planejamento dos municípios está alinhado com o planejamento do governo federal através de um mapa com parâmetros. Este mapa será o resultado de uma análise de diversos municípios (mercado) através dos PPA (produtos) e sua forma de construção (tecnologia).

O método do governo federal será o parâmetro ideal para fins de análise e comparação pelo conhecimento embutido através de sua estrutura e princípios. O processo de elaboração do PPA não será alvo desta pesquisa.

A Motorola foi a mais visível e levou o conceito ao setor de eletrônica, notadamente através das empresas Philips, Lucent Technologies, SIA, HP, Philips, ABB, GM, Vodafone, Boeing, NASA, Roche, Domino, Rockwell Automation, UK Post Office, dentre outras..

O uso exponencial da TRM na escala mundial mostra uma tendência de que ocorra o mesmo fenômeno aqui no Brasil, pois a sua flexibilidade e facilidade de uso trazem grandes resultados.

De forma geral, Phaal e Muller (2009) alegam que o formato do roadmap pode ser traduzido como uma lente estratégica. A TRM foi a base metodológica para a construção da analise do alinhamento de planejamento governamental e dos mapas comparativos deste artigo. 


\section{4 - Aplicação da Metodologia TRM ao cenário governamental}

Busca-se adequar a teoria do TRM ao contexto do planejamento governamental, para demonstrar como serão construídos o mapa, os quadros comparativos e o indicador de transferência de recursos do governo federal para os municípios. Esta pesquisa utilizará uma parte da ferramenta TRM que é a análise de mercado, com a qual compreende-se a análise competitiva do produto do PPA dos municípios com o do governo federal.

Considerando que o PPA é um produto comum entre as esferas federal e municipal, então podem ser consideradas em um mercado específico e comum. O cliente (a população) é o mesmo destinatário das ações governamentais das esferas federal e municipal. Os objetivos e metas institucionais são interligados, integrados e seguem o mesmo destino.

\section{1- Metodologia para elaboração do Mapa Comparativo (TRM)}

A aplicação desta pesquisa será montar o mapa comparativo de alinhamento do planejamento com base nos parâmetros estipulados, de forma que se tenha uma visão gráfica. Através da pesquisa e da análise documental das propostas dos PPAs enviados às Câmaras Municipais de suas cidades foi definido, graficamente, o alinhamento técnico, através de um código de cores:

a. Cor verde: o município está totalmente alinhado ao parâmetro;

b. Cor amarelo: o município está parcialmente alinhado ao parâmetro; e

c. Cor vermelha: o município não está alinhado ao parâmetro, configurando uma falta de sincronia técnica.

Na linha superior do mapa estarão os parâmetros adotados pelo governo federal e será considerada a referência para fins de compara- 
ção. As linhas abaixo serão destinadas aos 6 municípios, os quais serão analisados nos 14 parâmetros definidos neste estudo. O mapa do alinhamento técnico do planejamento terá uma forma de uma grande planilha, contendo 15 colunas e 7 linhas, os quadrantes terão retângulos com cores de acordo com a análise de alinhamento.

O mapa final permitirá uma análise tanto vertical como horizontal de cada município e, na relação entre os municípios facilitará a visualização, pois será possível analisar quem está mais ou menos alinhado.

\section{2 - Quadro de pontuação de alinhamento técnico de planejamento}

A tabela de pontuação do alinhamento técnico do planejamento governamental será construída com base no quadro de parâmetros técnicos acrescido de peso maior ou menor conforme o impacto de igual intensidade na qualidade do planejamento efetuado.

A pontuação de alinhamento técnico permitirá a análise mais qualitativa, pois permite estimar e mensurar certo grau de alinhamento técnico de cada parâmetro e município, permitindo, assim, uma análise e uma avaliação mais concreta.

\section{3 - Indicador de transferência de recursos federais via contratos e convênios por habitante de cada município}

Este indicador será elaborado com base em informações colhidas junto ao site do Instituto Brasileiro de Geografia e Estatística (IBGE) e do Tribunal de Contas Estadual (TCE), somente sobre os recursos transferidos via contratos e convênios de repasse.

Estas formas são: transferências legais automáticas; transferências legais fundo a fundo; transferências destinadas a sistema de saúde fundo a fundo; e transferências diretas ao cidadão. Essas formas não serão utilizadas tendo em vista que essas transferências têm pouca influência de decisão do município e a mínima necessidade de 
processos que exijam inteligência das gestões municipais, porque são definidas por critérios técnicos oriundos do governo federal.

As transferências de recursos viam contratos e convênios exigem um grande esforço técnico e de planejamento, além do cumprimento de exigências conforme prevê a gestão de recursos federais..

\section{5 - Resultados}

Os resultados da analise de cada parâmetro do planejamento governamental foram representados graficamente pelo Mapa TRM, pelo Mapa de Pontuação e pelo Indicador de Transferências via Convênios que exigem grande esforço de planejamento.

\section{1 - Mapa (TRM) com a análise do alinhamento técnico do planejamento governamental.}

\section{Quadro 1 - Mapa (TRM) do Alinhamento Técnico de Planejamento}

\begin{tabular}{|c|c|c|c|c|c|c|c|c|c|c|c|c|c|c|}
\hline & \multicolumn{14}{|c|}{$P A R A$} \\
\hline CIDADES AS & 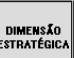 & 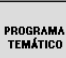 & 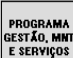 & \begin{tabular}{|l|l|} 
OBartwos \\
\end{tabular} & Meras & mecurtys & 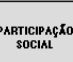 & 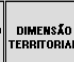 & 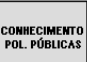 & 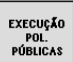 & necer & 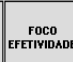 & $\begin{array}{c}\text { roceo } \\
\text { rickicich }\end{array}$ & 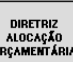 \\
\hline \multirow{2}{*}{\multicolumn{15}{|c|}{ PELOTAS }} \\
\hline & & & & & & & & & & & & & & \\
\hline \multirow{2}{*}{\multicolumn{15}{|c|}{ CanOAS }} \\
\hline & & & & & & & & & & & & & & \\
\hline & & & & & & & & & & & & & & \\
\hline \multicolumn{15}{|l|}{ TAQUaAaA } \\
\hline & & & & & & & & & & & & & & \\
\hline \multirow{2}{*}{\multicolumn{15}{|c|}{ D }} \\
\hline & & & & & & & & & & & & & & \\
\hline \multirow{2}{*}{\multicolumn{15}{|c|}{$\begin{array}{l}\text { CAMBAAAD D } \\
\text { SulL }\end{array}$}} \\
\hline & & & & & & & & & & & & & & \\
\hline Stoo & & & & & & & & & & & & & & \\
\hline $\begin{array}{l}\text { FEACISCDO } \\
\text { DE PAULAA }\end{array}$ & & & & & & & & & & & & & & \\
\hline
\end{tabular}

Totalmente alinhado 


\section{2 - Quadro de pontuação do alinhamento do planejamento dos municípios pesquisado.}

Tabela 1 - Quadro de Pontuação de Alinhamento do Planejamento

\begin{tabular}{|c|c|c|c|c|c|c|c|c|}
\hline & & & & & & & & \\
\hline & & & \multicolumn{6}{|c|}{ MUNICIPIOS PESQUISADOS } \\
\hline Item & Descrição do Parâmetro & $\begin{array}{l}\text { Pontuação } \\
\text { Máxima }\end{array}$ & Pelotas & Canoas & Taquara & Parobé & Cambará do Sul & $\begin{array}{c}\text { São Francisco } \\
\text { de Paula }\end{array}$ \\
\hline 1 & Dimensão Estratégica & 70 & 50 & 70 & 30 & 30 & 35 & 20 \\
\hline 2 & Programas Temáticos & 50 & 50 & 50 & 30 & 30 & 30 & 20 \\
\hline 3 & $\begin{array}{l}\begin{array}{l}\text { Programas de Gestão, Manutenção e } \\
\text { Serviços }\end{array} \\
\end{array}$ & 30 & 30 & 30 & 30 & 30 & 30 & 10 \\
\hline 4 & Objetivos & 30 & 30 & 30 & 15 & 15 & 15 & 15 \\
\hline 5 & Metas & 30 & 30 & 30 & 15 & 15 & 15 & 10 \\
\hline 6 & Iniciativa & 30 & 30 & 10 & 15 & 15 & 15 & 10 \\
\hline 7 & Participação Social & 50 & 40 & 50 & 10 & 30 & 10 & 10 \\
\hline 8 & Dimensão Territorial & 50 & 25 & 50 & 10 & 10 & 10 & 10 \\
\hline 9 & Conhecimento Políticas Públicas & 30 & 30 & 30 & 15 & 15 & 15 & 15 \\
\hline 10 & Execução de Politicas Públicas & 20 & 20 & 20 & 10 & 10 & 10 & 10 \\
\hline 11 & Parcerias & 40 & 40 & 30 & 20 & 20 & 20 & 20 \\
\hline 12 & Foco na Efetividade & 30 & 20 & 30 & 10 & 15 & 15 & 10 \\
\hline 13 & Foco na Eficácia & 20 & 20 & 20 & 10 & 10 & 10 & 5 \\
\hline \multirow[t]{2}{*}{14} & Diretriz na Alocação Orçamentária & 20 & 20 & 20 & 20 & 20 & 20 & 5 \\
\hline & TOTAIS DE PONTUAÇÄO & 500 & 435 & 470 & 240 & 265 & 250 & 170 \\
\hline
\end{tabular}

Fonte: Elaborado pelos autores

Com essa tabela é possível a elaboração de um ranking de alinhamento do planejamento governamental entre esfera federal e muni-

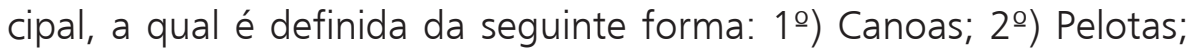
3) Parobé; 4으) (ambará do Sul; 5ㅇ) Taquara: e 6ำ) São Francisco de Paula.

A tabela de pontuação do alinhamento do planejamento está de acordo com o mapa do alinhamento elaborado com a ferramenta TRM e reflete na forma numérica a imagem gráfica gerada.

\section{3 - Indicador de transferência de recursos federais via contratos e convênios por habitante de cada município.}

Para iniciar a elaboração do indicador de transferência de recursos federais foi elaborado o Quadro de Receitas Federais recebida pelos Municípios no ano de 2014. 
Tabela 2 - Quadro de Receitas Recebidas da União no ano de 2014

\begin{tabular}{|c|c|c|c|c|c|c|c|c|c|c|c|c|c|c|c|c|c|}
\hline \multicolumn{18}{|c|}{ QUADRO RECEITAS RECEBIDAS PELOS MUNICIPIOS DA UNIÃO no ANO 2014} \\
\hline \multirow{2}{*}{\begin{tabular}{|c}
$\begin{array}{c}\text { Ranking } \\
\text { Alinhamento }\end{array}$ \\
$2^{0}$
\end{tabular}} & \multirow{2}{*}{$\begin{array}{c}\text { CIDADES RS } \\
\text { PELOTAS }\end{array}$} & \multicolumn{2}{|c|}{\begin{tabular}{|c|} 
Total Recursos Uniäo \\
FUNDEB
\end{tabular}} & \multicolumn{2}{|c|}{ Participą̧äo Rec. Uniäo } & \multicolumn{2}{|l|}{ sus * } & \multicolumn{2}{|l|}{ FNAS } & \multicolumn{2}{|l|}{ FNDE $\cdots$} & \multicolumn{2}{|c|}{$\begin{array}{c}\text { Compensagão Rec. } \\
\text { Naturais }\end{array}$} & \multicolumn{2}{|c|}{ FUNDEB - $\cdots$} & \multicolumn{2}{|c|}{ Diversos } \\
\hline & & || $273.638 .904,31 \mid$ & $100 \%$ & $56.476 .635,78$ & $20,64 \%$ & $107.762 .572,51$ & $39,38 \%$ & $2.579 .259,690$ & $0.94 \%$ & $11.848 .587 .86 \|^{4}$ & $4,33 \%$ & $664.213,56$ & $0,24 \%$ & $92.024 .032,55$ & $33,63 \%$ & $2.283 .602,36$ & $0,83 \%$ \\
\hline $1^{0}$ & CANOAS & $\mid$\begin{tabular}{|l|l|}
$369.327 .892,30$ \\
$\mid$
\end{tabular} & $100 \%$ & $56.039 .141,90$ & $15,17 \%$ & \begin{tabular}{l|l}
$162.928 .439,47$ & 4
\end{tabular} & $44, \pi 1 \%$ & $2.454 .203,710$ & $0,66 \%$ & $17.349 .54,7,724$ & $4.70 \%$ & $4.998 .906,26$ & $1,35 \%$ & $120.092 .530,73$ & $32,52 \%$ & 5.465. 128,51| & $1,48 \%$ \\
\hline $5^{0}$ & TAQUARA & 50.708.700,71| & 100\% & 23.182.840,98 & $45,72 \%$ & $3.152 .759,10$ & $6.22 \%$ & \begin{tabular}{|l|l}
$\mid 619.929,55$ & 1
\end{tabular} & $1,22 \%$ & $2874.766,295$ & $5,67 \%$ & $422.469,80$ & $0,83 \%$ & 19.81.258,17 & $39,07 \%$ & $644.076,82$ & $1,27 \%$ \\
\hline $3^{\circ}$ & PAROBÉ & 63.921.727.98 & $100 \%$ & 23.311.363,18 & $36,47 \%$ & \begin{tabular}{l|l}
$5.027 .891,93$ & 7
\end{tabular} & $7.87 \%$ & \begin{tabular}{||l||l}
$427.066,93$ & 0
\end{tabular} & $0,67 \%$ & $3.923 .041,14$ & $6,4 \%$ & 398.524,51 & $0,62 \%$ & |30.189.599,26 & $47,23 \%$ & 644.241,03 & | $1,01 \%$ \\
\hline $4^{0}$ & $\begin{array}{c}\text { CAMBARÁ DO } \\
\text { SUL }\end{array}$ & $10.199 .662,43$ & $100 \%$ & 6.438.545,77 & $63,13 \%$ & 851.617 .47 & $8,35 \%$ & 0,00 & $0,00 \%$ & $307.152,49 \mid 3$ & $3.07 \%$ & |130.235,29 & $1,28 \%$ & 2.267.194,92 & $22,23 \%$ & $204.916,49$ & | $201 \%$ \\
\hline $6^{0}$ & $\begin{array}{l}\text {;ÃO FRANCISCO } \\
\text { DE PAULA }\end{array}$ & 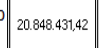 & |100\% & | $13.115 .403,19$ & $62.91 \%$ & $1204.582,92$ & $5,78 \%$ & 301.026,55 1 & $1,44 \%$ & \begin{tabular}{|l||l}
$670.905,82$ & 3 \\
\end{tabular} & $3.22 \%$ & |322.507,95 & $1.55 \%$ & $4.801 \cdot 109,02$ & $23,03 \%$ & 432.895,97 & $2,08 \%$ \\
\hline
\end{tabular}

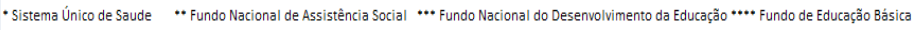

Fonte: Site Tribunal de Contas do Estado do RS - http://www1.tce.rs.gov.br

Analisando a tabela 3, constata-se que o governo federal apoia fortemente os municípios nas áreas da saúde, educação e bem menos na assistência social. Nos municípios de pequeno porte a participação da saúde, educação e assistência perde em importância para a participação da receita da União. Esse apoio do governo federal é realizado independente de assinatura de convênios nas transferências mediante dados estatísticos e condicionantes de gestão.

\subsection{1 - Quadro Indicador de Alinhamento - $\mathbf{R} \mathbf{\text { Habitante }}$}

A proposta deste indicador é verificar se os municípios mais alinhados com o PPA do governo federal obtiveram mais sucesso na captação de recursos federais, ele poderá mostrar o peso que o total dos recursos via convênios possuem em relação ao total dos recursos recebidos pelos municípios. A tabela 4 apresenta o indicador de alinhamento. 
Tabela 3 - Quadro Indicador de Alinhamento - Real/Habitante

\begin{tabular}{|c|c|c|c|c|c|c|c|}
\hline \multicolumn{8}{|c|}{ QUADRO INDICADOR DE ALINHAMENTO - R\$/HABITANTE } \\
\hline $\begin{array}{c}\text { Ranking } \\
\text { Alinhamento }\end{array}$ & CIDADES RS & Total Recursos Un & FUNDEB & $\begin{array}{r}\text { Transferências V } \\
\text { pela Un }\end{array}$ & onvênios & \begin{tabular}{|l} 
Indicador de Resultado de \\
Alinhamento RS/habitante
\end{tabular} & $\begin{array}{l}\text { Ranking } \\
\text { Indicador }\end{array}$ \\
\hline $2^{0}$ & PELOTAS & $273.638 .904,31$ & $100 \%$ & $1.349 .893,80$ & $0,49 \%$ & 4,11 & $4^{0}$ \\
\hline $1^{0}$ & CANOAS & $369.327 .892,30$ & $100 \%$ & $615.811,49$ & $0,17 \%$ & 1,90 & $6^{0}$ \\
\hline $5^{0}$ & TAQUARA & $50.708 .700,71$ & $100 \%$ & $1.035 .589,53$ & $2,04 \%$ & 18,95 & $2^{0}$ \\
\hline $3^{0}$ & PAROBÉ & $63.921 .727,98$ & $100 \%$ & $149.096,25$ & $0,23 \%$ & 2,89 & $5^{0}$ \\
\hline $4^{0}$ & CAMBARÁ DO SUL & $10.199 .662,43$ & $100 \%$ & $206.997,39$ & $2,03 \%$ & 31,64 & $1^{0}$ \\
\hline $6^{\circ}$ & SÃO FRANCISCO DE PAULA & $20.848 .431,42$ & $100 \%$ & $186.150,39$ & $0,89 \%$ & 9,06 & $3^{\circ}$ \\
\hline
\end{tabular}

Fonte: Elaborado pelos autores a partir dos dados do TCE e IBGE

Analisando o indicador de alinhamento - R $\$ /$ Habitante percebe-se que a análise do mapa do alinhamento do planejamento do PPA com o indicador não possuem uma relação direta com tendência de contradição ranking de alinhamento com o indicador elaborado.

Outra constatação é que o peso dos recursos via convênios é muito baixo (de $2 \%$ pra baixo) em relação ao total dos recursos repassados pelo governo federal aos municípios. Este resultado indica talvez o porque os municípios não invistam em equipes tecnicamente capacitados para elaborarem convênios tendo em vista que o retorno não é muito significativo para os municípios.

O indicador de alinhamento e o ranking de alinhamento são contraditórios nos seus resultados, demonstrando que alguns fatores podem ter influenciado esta dissociação.

\section{Considerações finais}

O objetivo geral desta pesquisa foi verificar se o alinhamento técnico do planejamento governamental da esfera federal (PPA 20122015) com a esfera municipal (PPAs 2014-2017) de alguns municípios poderia garantir uma vantagem técnica na captação dos recursos federais no ano de 2014. 
Após a coleta de informações estatísticas e de valores repassados pelo governo federal, começa a transparecer um novo cenário contraditório ao anterior. Os dados coletados indicaram que os recursos oriundos de convênios eram pífios e de pouco impacto sobre o total da receita federal repassada via transferências fundo a fundo, ou transferências legais automática.

A maioria dos municípios não realiza seus planejamentos com base em um diagnóstico, macro desafios ou análise territorial na tentativa de conhecer suas potencialidades, ameaças e oportunidades. Os PPAs demonstram que as gestões governam sem uma visão clara estratégica e com base em estudos técnicos.

A maioria dos municípios não adota a participação social como um dos eixos principais de sua gestão na busca da governabilidade, contrariando a Constituição Federal e desqualificando a importância de seus planejamentos. Analisando esta governabilidade, através do triangulo de governo conceituado por Dagnino (2009), verifica-se que o descaso em escrever o projeto de governo atinge diretamente os outros dois vértices do triangulo: a capacidade de governar e o apoio político.

A pouca valorização da tecnologia do planejamento, por parte da maioria das gestões, promove a baixa efetividade (promover resultados pretendidos), baixa eficiência (produzir resultados no momento certo e com mínimo de esforço), e a baixa eficácia.

Assim, nessa linha da pouca valorização ao planejamento, o governo federal atua influenciando de forma direta na acomodação dos municípios. As áreas da educação, saúde e assistência social são estratégicas e há um apoio conjunto das esferas federal e municipal, em virtude do aporte de recursos nessa área. As demais áreas de atuação de um governo ficam para segundo plano. Assim, devido à falta de visão estratégica local estas áreas são as mais prejudicadas e abandonadas nos planejamentos municipais.

Como os recursos de convênios (com esforço de planejamento) representam no máximo $2 \%$ do total da receita repassada aos municípios, ou seja, no mínimo 98\% das receitas federais via transferência 
fundo a fundo ou participações legais e automáticas (pouco esforço de planejamento), Isso induz os municípios à acomodação geral, promovendo que a dimensão tática do planejamento seja muito fraca em sua estrutura organizacional e pessoal.

Finalizando esta pesquisa, pode-se ampliar sua análise, tanto nos próximos anos de execução dos PPAs municipais (2014-2017) como no número dos municípios pesquisados, aumentando a base de estudo deste trabalho. A análise foi realizada somente com relação a 1 (um) ano dos PPAs e, portanto, pode ser alvo de trabalho futuro.

A conclusão final desta pesquisa é que o alinhamento técnico de planejamento não favorece um maior repasse de recursos federais aos municípios. Foi interessante entender, de uma forma técnica e científica, porque a macro função planejamento não é relevante para as gestões municipais e, ao mesmo tempo, o porquê a maioria das gestões municipais têm pouca efetividade, eficácia e eficiência em suas ações. O estudo confirmou a percepção existente de uma lacuna entre a dimensão estratégica e a operacional: a inexistência da dimensão tática nas gestões, o que acarreta em baixos resultados na governabilidade das gestões municipais.

\section{Referências}

BRASIL. Constituição de 1988. Brasília, DF: Senado Federal.

BRASIL. Modelo de planejamento governamental. Secretaria de Planejamento e Investimentos Estratégicos. Ministério do Planejamento,Orçamento e Gestão. Brasília: MP, 2012.

BRASIL. Programa de apoio à elaboração e implementação dos PPAs municipais - 2014-2017. Agendas de Desenvolvimento Territorial Ministério do Planejamento, Orçamento e Gestão. 2013. 183 p.

BRASIL. Orientações para elaboração do Plano Plurianual 2012-2015. Secretaria de Planejamento e Investimentos Estratégicos. Ministério do Planejamento, Orçamento e Gestão. Brasília: MP, 2011.

CHIAVENATO, I. Recursos humanos na empresa: pessoas, organizações e sistemas. 3.ed. São Paulo: Atlas, 1994. p. 67-76. 
DAGNINO, R. Planejamento estratégico governamental. 2009.

DRUMMOND, P.O planejamento tecnológico de uma empresa de base tecnológica de origem acadêmica por intermédio dos métodos technology Roadmapping (TRM), technology stage-gate (TSG) e processo de desenvolvimento de produtos (PDP) tradicional.

ESTUDO DA FIRJAN APONTA que 83\% dos municípios não se sustentam. O Impacto. 2012. Disponível em: <http://www.oimpacto.com.br/atualidades/estudo-da-firjan-aponta-que-83-dos-municipios-nao-se-sustentam/> .

GARCIA, M.; BRAY, O. Fundamentals of technology Road mapping. Sandia National Laboratories. 1997. Disponível em: www.sandia.gov/ PHMCOE/pdf/Sandia'sFundamentalsofTech.pdf>. Acesso em: 15 jul. 2008.

HENDERSON, J.; VENKATRAMAN, N. Strategic alignment: leveragind information technology for transforming organizations. IBM v. 32, 1993.

KAPPEL, T. Perspectives on roadmaps: how organizations talk about the future. Journal of Product Innovation Management. v.18, n.1, p.39-50, 2001.

MARINHO, A.; FAÇANHA, L. Programas sociais - efetividade, eficiência e eficácia como dimensões operacionais da avaliação. Rio de Janeiro: IPEA, 2001.

MATTOS NETO, P. Planejamento de novos produtos por intermédio do método Technology Roadmapping (TRM) em uma empresa de base tecnológica do setor de internet móvel. Belo Horizonte, 2005.

PHAAL, R.; FARRUKH, C.; PROBERT, D. T-Plan: fast start to technology roadmapping- planning your route to success. UK: Cambridge University Institute of Manufacturing, 2001a.

WEELS, R.; PHAAL, R.; FARRUKH, C.; PROBERT, D. Technology Roadmapping for roadmapping for a service organization. Research Technology Management. Março, 2004. 


\title{
A Democratização da Comunicação Social no Brasil e a Gestão da Comunicação Pública no Município de Porto Alegre
}

\author{
Rita de Cássia da S. Becco' \\ Marcelo Cortimiglia
}

\section{Introdução}

A democratização da comunicação social no Brasil é um tema recorrente no cenário político nacional, ora ocupando posição de destaque na agenda política, ora caindo em esquecimento. Após os exaustivos debates na Assembleia Nacional Constituinte e a promulgação da Constituição de 1988 (que dedica um capítulo exclusivo ao tema), as discussões subsequentes em torno da democratização do setor não foram capazes de promover a regulamentação dos artigos definidos pelos deputados constituintes (LIMA, 2013). Por duas décadas, o debate sobre o tema junto à sociedade não foi ampliado e o texto original acabou sofrendo mudanças em aspectos importantes por meio de Emendas Constitucionais. Porém, a realização da $1^{a}$ Conferência Nacional de Comunicação, em dezembro de 2009, revigorou o debate e, pela primeira vez, institucionalizou as discussões sobre radiodifusão, mídia impressa, internet, comunicação comunitária e alternativa, comunicação

Especialista em Gestão Pública Municipal - EA/UFRGS.

Doutor em Ingegneria Gestionale pelo Politecnico di Milano, Itália. Professor Adjunto da UFRGS. 
pública e sobre o papel do Estado e da sociedade na definição de regras para este setor.

Dentre as propostas da Conferência Nacional, destaca-se a necessidade de inclusão da gestão da comunicação pública como um dos componentes do desejado marco regulatório do setor, em particular o controle da destinação dos investimentos em publicidade feitos pelos governos. Passados cinco anos da Conferência, a avaliação dos atores políticos ligados aos movimentos sociais favoráveis à regulamentação é, contudo, cética em relação aos avanços. E particularmente em relação à comunicação pública, a crítica é contundente:

Outro setor em que houve claro retrocesso foi na distribuição de verbas publicitárias do governo. Sob o argumento de utilizar "critérios técnicos" como audiência e tiragem, a Secretaria de Comunicação da Presidência (Secom-PR) mantém a lógica de que os grandes recebem mais. Concentra a maior parte dos seus recursos na radiodifusão e praticamente ignora o peso que a internet vem ganhando nos hábitos de consumo de comunicação na sociedade, e, além disso, menospreza a mídia alternativa, livre e comunitária. (Conjuntura da Comunicação no Brasil, - FNDC, 2014).

O Fórum Nacional pela Democratização da Comunicação (FNDC), criado ainda na década de 1990, congrega entidades da sociedade civil que unem esforços pela efetiva democratização dos meios de comunicação.

Em meio a esse cenário complexo, no qual a Democratização da Comunicação Social vai ao encontro de outras pautas igualmente polêmicas e atuais, como a reforma política e o combate à corrupção na esfera pública, o presente estudo apresenta-se como um esforço de cunho acadêmico no sentido de analisar as principais variáveis envolvidas na gestão das verbas destinadas à comunicação pública, tomando como referência a gestão da comunicação social no Município de Porto Alegre. 
O trabalho investiga a hipótese de que a participação do segmento comunicação pública no debate nacional sobre democratização da comunicação social passa pelo aprimoramento dos mecanismos de gestão, com foco na participação, definição de diretrizes, controle social e transparência. Nesse sentido, Porto Alegre e seus investimentos em publicidade constitui um exemplo de como a verba pública é atualmente gerida em um munícipio brasileiro de grande porte. Tal abordagem mostra-se oportuna uma vez que a amplitude e a complexidade da agenda nacional podem ofuscar o relevante papel da gestão da comunicação pública local na construção de espaços de gestão mais democráticos neste setor. Para tanto, o problema de pesquisa consiste em compreender a relação entre os temas e assim responder a questão: "Como se estabelece a relação entre democratização da comunicação social no Brasil e a gestão da comunicação pública local?"

Para responder a questão central da pesquisa, adota-se como objetivo geral: identificar e analisar a contribuição da gestão da comunicação pública local no processo de democratização da comunicação social. E, como objetivos específicos: descrever a gestão da comunicação pública municipal em Porto Alegre, incluindo suas estruturas, estratégias e investimentos; analisar as despesas em publicidade feitas pela administração municipal, considerando o orçamento e os mecanismos de transparência e controle; apontar possibilidades de melhoria na gestão da comunicação pública local relacionando-as com os temas do debate nacional sobre a democratização da comunicação social; e discutir como a gestão dos investimentos em publicidade das prefeituras pode contribuir para o debate nacional sobre o processo de democratização da comunicação social.

\section{Metodologia}

As informações levantadas para a realização do trabalho são oriundas de pesquisa bibliográfica e documental de dados secundários da Prefeitura de Porto Alegre, de entidades da sociedade civil 
como o FNDC, órgãos de controle, como o Tribunal de Constas do Estado do RS, e de veículos de notícias e de conteúdo especializado em comunicação social na internet. A técnica escolhida para análise, interpretação e apresentação dos dados levantados foi a análise de conteúdo, considerando as fases de pré-análise, análise do material (ou descrição analítica do conteúdo) e a interpretação dos resultados.

O estudo teve três etapas distintas, sendo a primeira uma pesquisa documental de dados secundários e bibliográfica do conteúdo produzido pela academia e grupos organizados pró-regulamentação da mídia e a verificação da base legal da agenda referenciada pela Constituição Federal de 1988. Na sequência, a pesquisa buscou na bibliografia especializada o conceito de comunicação pública, cuja definição e delimitação orientaram a análise sobre a gestão comunicação pública em Porto Alegre, etapa final na qual os dados foram obtidos através dos canais oficiais de comunicação da Prefeitura e do Tribunal de Contas do Estado.

\section{Democratização da Comunicação Social no Brasil}

O debate sobre a democratização e o papel e da comunicação social no Brasil teve como cenário de um de seus capítulos mais emblemáticos a Assembleia Nacional Constituinte (ANC) de 1987-88 quando deputados, entidades sociais e empresários apresentaram propostas distintas para a regulamentação do setor. A então Frente Nacional por Políticas Democráticas de Comunicação (FNPDC) foi a entidade em torno da qual o grupo de pressão formado por progressistas uniu esforços para consolidação de uma proposta de regulamentação do setor, incluindo em sua agenda as concessões de canais de rádio e TV, a propriedade dos meios, o incentivo à produção cultural regional, a responsabilização pelos conteúdos veiculados e, principalmente, a criação de mecanismos de controle e participação e da sociedade.

As discussões logo resultaram em um ferrenho embate de contornos ideológicos e políticos, no qual progressistas e conservadores 
disputaram, muitas vezes de forma desigual, a hegemonia de suas propostas. Além da presença constante de empresários influentes, como o gaúcho Jayme Sirotsky, do grupo RBS. Vale ressaltar que grande parte dos constituintes eram eles mesmos proprietários de rádio difusoras espalhadas por todo o país.

O resultado desse confronto foi a inclusão de um capítulo na Constituição Federal de 1988 que trata de forma exclusiva das questões de comunicação social no país, porém sem desdobrá-las em regulamentações específicas. O Capítulo 5 do Título VIII da carta magna, intitulado 'Da Comunicação Social' é dividido em cinco artigos: 220, 221, 222, 223 e 224, que em seu conjunto expressam a preocupação dos constituintes, as contradições e limitações das diferentes visões que permearam o exaustivo debate.

A inclusão do capítulo específico sobre comunicação social na Constituição Cidadã é considerada ainda hoje um avanço (GUARESCHI, 2013. p.46), porém as expectativas em relação aos seus desdobramentos foram aos poucos aplacadas a cada tentativa frustrada de regulamentação. Também contribuíram para o ceticismo dos progressistas, mudanças de percurso, como nos casos do artigo 222 (regulamentação da entrada do capital estrangeiro nas empresas de comunicação no Brasil) e das restrições ao papel do Conselho Nacional, referenciado no artigo 224.

Nesse contexto marcado por conflito de interesses, os investimentos em publicidade oficial são apontados por teóricos e profissionais do setor como fator relevante, na medida em que ao desconcentrar os investimentos nos grandes grupos de comunicação o governo, além de incentivar a mídia alternativa, deixaria de financiar um segmento tradicionalmente resistente à regulamentação da comunicação social. Nessa visão, caberia ao governo, a partir da gestão dos investimentos em publicidade, agir usando o poder econômico como instrumento de pressão na relação entre as partes envolvidas na referida agenda pública. 


\section{Comunicação Pública, um conceito em formação}

Os primeiros trabalhos acadêmicos sobre comunicação pública estatal/governamental remontam à década de 1980 (HASWANI, 2013) e se caracterizam por apresentar, mesmo que de forma embrionária, um enfoque menos operacional e mais sociopolítico do conceito e do papel da atividade. Nessa abordagem mais ampla percebe-se a inter-relação da temática com outras áreas do conhecimento como a sociologia, a ciência política, a filosofia, o direito e a psicologia social.

Segundo a professora Elizabeth Brandão "a expressão comunicação pública vem sendo usada com múltiplos significados, frequentemente conflitantes, dependendo do país, do autor e do contexto em que é utilizada." (BRANDÃO, 2012). Ainda segundo a autora, tais diferenças corroboram para ideia de que não há um conceito claro sobre a expressão comunicação pública, levando-a a afirmar de que se trata de um conceito em processo de construção, percepção compartilhada por este trabalho.

A escola europeia, cuja influência é percebida também em países latino-americanos, associa a comunicação pública à garantia dos direitos e à consolidação do Estado Democrático. Tendo como marco o trabalho do pesquisador francês Pierre Zémor que em 1995 publicou o livro La communication publique e mais recentemente, em 2008, La communication publique en pratique, traduzidos livremente por acadêmicos brasileiros. Essa perspectiva da comunicação pública como informação para construção da cidadania, onde o interesse público e a esfera pública ocupam papel central, é percebida como ponto comum nas diversas tentativas de conceituação do termo por autores brasileiros (DUARTE, 2012).

No Brasil, segundo Brandão, o ponto comum entre os pesquisadores sobre o conceito de comunicação pública é "aquele que diz respeito a um processo comunicativo que se instaura entre o Estado, o governo e a sociedade com o objetivo de informar para a construção da cidadania."

Neste trabalho adota-se o conceito de comunicação pública pro- 
posto por Brandão o qual não delimita a atividade à comunicação feita por órgãos estatais e governos:

A comunicação Pública é o processo de comunicação que se instaura na esfera pública entre Estado, o Governo e a Sociedade e que se propões a ser um espaço privilegiado de negociação entre os interesses das diversas instâncias de poder constitutivas da vida pública no país (BRANDÃO, 2012, p. 9).

Depreende-se do conceito adotado a ressalva de que comunicação pública não é só comunicação governamental e diz respeito ao Estado e não aos governos interpretação também presente no trabaIho de Ricardo Melo que questiona o uso da comunicação governamental como instrumento para construção de imagem e rapasse de informação oficial dos governos (ação transitória, com menor potencial de mudança) e conclama sua substituição pela comunicação de Estado (ação perene, comprometida com valores de cidadania).

\section{Publicidade no setor público: técnica de comunicação mercadológica ou estratégia para a cidadania?}

Ao pesquisar o termo publicidade no contexto da gestão da comunicação pública é possível perceber duas abordagens distintas: uma voltada para a prática profissional que tem por origem as técnicas e princípios da disciplina de marketing e outra, cuja referência é o conceito de publicização dos atos da administração pública como direito garantido ao cidadão pela constituição federal de 1988.

Na perspectiva do composto de marketing, a publicidade é uma ferramenta de promoção com apelo comercial, caracterizada por aliar estética e discurso persuasivo para induzir o público alvo à decisão de compra de produtos e serviços ou para implementar e manter conceitos positivos da empresa junto aos clientes.

Segundo Haswani, os princípios e técnicas de persuasão da abordagem mercadológica que vêm sendo utilizados também no campo 
estatal e governamental podem servir "parcialmente e com indispensáveis adaptações" nas etapas operacionais da comunicação pública.

Já a abordagem de publicidade baseada na corrente de pensamento que referencia o acesso à comunicação social como um direito da pessoa e um dos pré-requisitos dos Estados Democráticos, posiciona essa ação comunicativa em uma dimensão estratégica da administração pública, conferindo a ela um papel preponderante na consolidação da cidadania (SILVA, 2012).

A Constituição Federal de 1988 no artigo 37, do Capítulo VII, dedicado à Administração Pública, ao definir o princípio da publicidade explicita a preocupação dos constituintes em assegurar o acesso à informação concernente aos atos administrativos e à transparência na gestão dos recursos públicos:

$\S 1$ ㅇ - A publicidade dos atos, programas, obras, serviços e campanhas dos órgãos públicos deverá ter caráter educativo, informativo ou de orientação social, dela não podendo constar nomes, símbolos ou imagens que caracterizem promoção pessoal de autoridades ou servidores públicos.

A adoção do conceito de publicidade como prática que lança mão de um manancial técnico e instrumental afinado pelo e para o mercado, mas que ocupa um posicionamento estratégico na esfera pública por conta do indispensável embasamento sócio-político sobre seu papel nos Estados democráticos, se faz presente nas análises subsequentes deste trabalho sempre que o termo for mencionado.

\section{Obstáculos e limitações que desafiam a gestão da comunicação e da publicidade no setor público}

A publicidade enquanto instrumento de consolidação da cidadania encontra no setor público obstáculos inerentes à própria natureza do poder e às suas manifestações, disputas e conflitos próprios dos regimes democráticos. 
Silva (2012, p. 185) avalia que há entre o poder e a publicidade uma relação paradoxal, na medida em "é próprio do poder ser transparente apenas no que estrategicamente Ihe interessa [...] o Estado, por sua vez, para se legitimar, tem que ser visível para com seus mantenedores, os cidadãos." Essa relação conflitante torna-se mais acirrada quando governantes uma vez no poder buscam a permanência apoderando-se do Estado, aparelhando-o em benefício de partidos e interesses patrimoniais e com isso restringindo da publicidade o seu caráter de serviço público.

Nesse ponto vale salientar que também no campo da comunicação pública o patrimonialismo, que tão fortemente marcou a formação política e econômica do Brasil, mostra a sua face. No artigo "Publicidade do poder, poder da publicidade" o professor Luiz Martins da Silva discorre sobre uma prática que remete à ideia de usufruto da coisa pública para fins particularizados a partir dos recursos de publicidade:

Os candidatos, uma vez no poder, tendem a encontrar formas de premiar agências de publicidade e publicitários, respectivamente, com as melhores contas de governo e com posições políticas que resultam em poderosas influências no rateio das verbas da publicidade oficial. Ainda que não ocupem cargos públicos, tais personalidades do mundo da publicidade se estabelecem, ad hoc, como eminências pardas, não só influindo no destino de verbas, como também tendo um papel colaboracionista no trato da "imagem" dos governantes... (SILVA, 2012, p. 187).

Conforme relatado anteriormente a comunicação pública como ferramenta de consolidação do Estado Democrático é um importante ingrediente na transformação do Estado Herdado (personalizado, não transparente e patrimonialista) para o Estado Desejado (democrático, participativo e cidadão). Assim, uma análise, ainda que breve, sobre os recursos existentes para salvaguardar a probabilidade de que o poder político estabelecido como autoridade pública se utilize 
de cargos e de órgãos públicos para fins patrimonialistas no campo da comunicação pública mostra-se pertinente.

Nesse sentido, vale destacar a atuação de dois órgãos oficiais que na esfera estadual agem como mecanismo de controle da gestão da comunicação pública em questões específicas, a saber, o Tribunal de Contas que fiscaliza as despesas de comunicação pública e de publicidade, em particular, e o Tribunal Regional Eleitoral que normatiza cronograma, conteúdo e formas de assinatura das peças e campanhas de comunicação nos períodos que antecedem as eleições. Um terceiro recurso refere-se ao poder legislativo e sua prerrogativa de solicitar esclarecimentos aos governantes e abrir processos investigativos. Esse arranjo institucional embora fundamental, não contempla a participação direta do sujeito alvo da comunicação emitida pelos governos, o cidadão. Tampouco o agente público com formação técnica e atuação profissional no setor encontra nessa configuração um espaço de construção de mecanismos internos de controle sobre a atuação dos agentes políticos.

\section{A importância da política pública para a função social da comunicação}

A definição de políticas públicas é uma função do Estado, cuja autoridade soberana exerce poder regulatório que se estende sobre toda a sociedade (RUAS, 2009). Todavia, as demandas referentes à democratização da comunicação seja no campo da propriedade dos meios ou da transparência dos atos da administração pública, incluindo as despesas com publicidade, não encontram, no âmbito do Estado, diretrizes estabelecidas na forma de determinações legais, uma vez que a própria regulamentação dos artigos do capítulo $V$ da Constituição Federal ainda não conseguiu ser definida, passados 27 anos da sua promulgação.

A ausência de diretrizes gerais no campo da comunicação pública combinada com as indefinições acerca do conceito, abrangência, atores e a própria finalidade desta atividade profissional no serviço 
público constituem um cenário de fragilidade para o planejamento e continuidade das ações de comunicação no longo prazo. Ao analisar a atuação dos comunicadores públicos nesse contexto, Jorge Duarte afirma que:

Para o profissional, o desafio é lidar com um tema cujo objetivo estratégico muitas vezes está mais relacionado a atender aos anseios do corpo dirigente do que ao interesse público... contrariando sua legítima missão de colocar a centralidade do processo da comunicação no cidadão, não apenas por meio da garantia do direito à informação e à expressão, mas também do diálogo. (DUARTE, 2012).

A exemplo da organização e controle alcançados pela implementação de políticas públicas nas áreas de saúde, educação e assistência social, a comunicação pública também necessita que o Estado, no exercício de sua autoridade soberana, encaminhe a agenda pública pela democratização da comunicação social, viabilizando a implementação de uma política pública para o setor.

Nesse sentido, o reconhecimento da necessidade de regras gerais para orientar a atuação profissional do comunicador público encontra no debate nacional pela democratização da comunicação social uma rede de apoio já estabelecida e ativa. A concentração das demandas dos dois grupos (comunicadores públicos e ativistas pró-regulamentação da mídia) representa uma situação de oportunidade, no contexto de desenvolvimento das políticas públicas, em virtude da natureza, da complementariedade e da temporalidade das suas demandas, mesmo considerando a resistência que a pauta central provoca em determinados atores da esfera pública.

\section{A comunicação pública na Prefeitura de Porto Alegre}

A atividade de comunicação da Prefeitura de Porto Alegre possui uma estrutura central vinculada diretamente ao Gabinete do Prefeito, denominada Gabinete de Comunicação Social (GCS) e setores 
descentralizados que respondem pela atividade em grande parte das 30 secretarias que integram a administração municipal. Os órgãos municipais não apresentam uma uniformização de estrutura de comunicação: enquanto algumas secretarias possuem áreas e recursos humanos definidos para as atividades de assessoria de imprensa, eventos e publicidade e propaganda, outras possuem apenas a figura do assessor de comunicação, com função prioritária de gerenciar o relacionamento e as demandas da imprensa local.

O presente trabalho concentra sua análise no formato do Gabinete de Comunicação Social porque as ações publicidades são geridas de forma centralizada por esta estrutura, sendo ela a responsável por definir quais, onde e como serão realizadas as campanhas de divulgação que envolvem anúncios nos veículos de comunicação e outras ações de comunicação pagas pelo executivo municipal.

A missão do GCS é assim definida no Manual do Modelo de Gestão da Prefeitura de Porto Alegre:

Ampliar e qualificar a comunicação entre governo e sociedade, por meio da mídia e utilização de novas tecnologias de forma a promover o engajamento da população às políticas públicas. (PMPA, 2014)

A peça gráfica, com tiragem de mil exemplares e versão digital disponível na internet, informa também os macroprocessos da área como sendo: Planejamento da política de comunicação (governança da política de comunicação, alinhamento da comunicação das secretarias com a sociedade); Gestão do processo de comunicação (relacionamento com as mídias externas e assessorias, produção de conteúdo, gerenciamento dos canais de comunicação disponíveis, contratar mídia, desenvolvimento de novos produtos, realizar pesquisa de opinião e capacitações, pesquisa e utilização de novas tecnologias (benchmarking, estabelecimento de parcerias, utilização das TICS, capacitação e pesquisas de novos TICS). 
De acordo com a publicação Governo Municipal Legislação Organizacional do Executivo Municipal de Porto Alegre, para atender os propósitos definidos em seus macroprocessos o GCS apresenta a seguinte estrutura: Coordenação Porto Alegre Digital, Unidade de Jornalismo e Unidade de Publicidade e Propaganda.

Ainda em relação à estrutura e atividades macro do GCS, cabe ressaltar a não divulgação nos sites oficiais da política de comunicação e seu detalhamento informando a forma como se dá a governança e a deliberação dos recursos e prioridades; também não foi localizado o regramento ou a forma como é feito o alinhamento das ações de comunicação das secretarias municipais. Outra atividade citada entre os macroprocessos, cujos conteúdos e regramentos não foram localizados nos sites, é a pesquisa de opinião sobre os serviços municipais feita de forma periódica junto à população: não informação sobre a periodicidade, acesso aos dados e ao contrato de prestação de serviço.

A Unidade de Publicidade e Propaganda possui um posto de chefia que gerencia as atividades de suas duas áreas internas: o setor de criação, responsável pela criação de layouts e identidades visuais de peças de comunicação e apresentações, este setor é formado por dois servidores efetivos e dois estagiários de ensino superior; e o setor de planejamento e atendimento, responsável por receber e encaminhar as demandas de publicidade das secretarias, este setor é formado três cargos em comissão e dois estagiários de ensino superior. Este nível de detalhamento não é mostrado no site, mas as informações foram facilmente obtidas por contato telefônico sem exigências de documentação ou prazos de resposta.

Nessa formatação, compete à chefia da Unidade de Publicidade contratar, gerenciar e fiscalizar os serviços publicidade oferecidos por agências especializadas. O atual contrato data de 9 de junho de 2011, resultante de processo licitatório modalidade técnica e preço vencido pela Agência Centro de Propaganda Ltda., tendo passado por 12 aditamentos, sendo o último realizado em 30 de janeiro de 2015. Estas informações estão disponíveis no portal de transparên- 
cia, porém para fazer a consulta é preciso que o internauta saiba informar a razão social ou o CNPJ do fornecedor, tal condicionante limita o acesso ao acompanhamento de informações como os termos de aditamento de contrato e os pagamentos executados, obrigando o usuário a buscar a informação requerida pelo portal em outras fontes. Os serviços prestados pela agência incluem a criação publicitária de peças de comunicação, produção gráfica (orçamentação, negociação de prazos e formatos junto a fornecedores terceirizados) e a elaboração de planos de mídia (planilhas que definem a contratação dos espaços pagos nos veículos de comunicação local).

Desde 2005 foi estabelecido o Comitê Gestor de Comunicação, formado por representantes do primeiro e segundo escalões do Gabinete do Prefeito, do GCS, da Secretaria de Coordenação Política e Governança Local, da Procuradoria Geral do Município, da Companhia de Processamento de Dados do Município, das agências de publicidade (por um período houve três agências contratadas) e de órgãos convidados, com o intuito de discutir e definir as campanhas de publicidade prioritárias para a administração municipal. Todavia não há informações ou registros das pautas e atas dessa instância deliberativa nos sites dos órgãos diretamente envolvidos na formatação do comitê gestor, tampouco dos critérios adotados pelo grupo para alocação dos recursos de publicidade.

Quanto às entregas e resultados prioritários do GCS, a referência é o Manual de Gestão, que a partir de uma metodologia de gestão, informa e publiciza o compromisso assumido por todas as secretarias municipais junto ao GP e à sociedade para o ano de 2015. Na peça gráfica as prioridades do GCS para o corrente ano são assim estabelecidas:

1) Realizar 3 capacitações para servidores da Prefeitura na área da comunicação;

2) Ampliar de 102,8 mil para 130 mil o número de seguidores dos canais de mídia social;

3) Ampliar de 46 para 92 o número de conjuntos de dados governamentais disponíveis no Portal DataPoa. 
4) Garantir que $50 \%$ das matérias, publicadas no Portal da Prefeitura, sejam relacionadas à prestação de serviços;

5) Realizar 3 projetos por meio de parcerias. (PMPA, 2014)

Constata-se o estabelecimento de metas ligadas às atividades de comunicação digital e jornalismo; nenhuma ação de publicidade paga foi identificada, nesta metodologia, como compromisso de entrega do GCS para o GP e a sociedade.

\section{O orçamento da atividade de publicidade na Prefeitura de Porto Alegre}

Este tópico apresenta o orçamento da atividade de publicidade tomando por base a execução orçamentária do contrato com a Agência de Publicidade Centro no ano de 2014, tendo com fonte de pesquisa os dados disponibilizados no Portal de Transparência no site da Prefeitura de Porto Alegre.

O orçamento gerenciado pela Unidade de Publicidade do GCS é formado pela soma da dotação orçamentária de todas as secretarias municipais para a cobertura das despesas de atividade de publicidade, codificadas no orçamento público municipal pelo número 2873. O orçamento consolidado sob essa codificação é gerido pela Unidade de Publicidade do GCS que passa a definir as ações dos órgãos municipais que contarão com campanhas publicitárias pagas por este fundo comum. A pesquisa dos valores empenhados pelo município, no ano de 2014, à Agência Centro de Propaganda Ltda. demonstrou que a composição total das despesas com as atividades de publicidade dos 30 órgãos da administração direta e indireta do município foi de $R \$ 21,1$ milhões. Dentre os maiores orçamentos destacam-se: Secretaria Municipal da Saúde ( $\$ 33,0$ mi), Secretaria Extraordinária da Copa (R\$3,0 mi), Secretaria Municipal da Fazenda $(R \$ 2,6)$, Secretaria Municipal de Gestão (R\$1,7 mi), Secretaria Municipal de Administração ( $R \$ 1,5 \mathrm{mi})$; Gabinete do Prefeito ( $R$ \$1,5 mi), Secretaria Municipal de Governança Local (R\$1,3 mi), e o Departamento Municipal 
de Água e Esgoto ( $\mathrm{R} \$ 1,1 \mathrm{mi}$ ). Porém, não foi possível pelo portal de transparência verificar o quanto deste montante foi empenhado em 2014 especificamente para cobrir as despesas com a compra de anúncios pagos nos veículos de comunicação locais.

A pesquisa pelas informações referentes à estrutura e às despesas da área de comunicação social da Prefeitura de Porto Alegre indica que o nível de informação sobre a gestão da área de comunicação, atualmente disponibilizado ao cidadão, é deficitário tanto no portal de transparência quanto no site institucional do Gabinete de Comunicação Social (GCS).

O site do Gabinete de Comunicação está estruturado de forma a prestar informações diretamente relacionadas aos produtos de comunicação ofertados pelo órgão e a informar o contato das assessorias de cada secretaria do governo municipal. Essa plataforma não apresenta a estrutura detalhada do GCS, também não informa sobre a missão, visão e valores, como fazem os sites de diversos órgãos da Prefeitura explicitando o alinhamento ao modelo de gestão gerencial, implantado há 10 anos em toda a administração municipal. Também não foram localizados registros da política e diretrizes de comunicação adotadas pelo órgão, não há Decretos, Instruções Normativas ou outros documentos que tratem sobre a organização, métodos e processos de comunicação social. Tampouco foram encontradas referências às instâncias de participação e governança interna mencionadas pelos integrantes da Equipe de Planejamento a Atendimento da Unidade de Publicidade do GCS, a saber, os Comitês Gestores de Comunicação e de Eventos, não há registro do cronograma ou periodicidade das suas reuniões, das deliberações e encaminhamentos.

O acompanhamento das despesas da área pode ser feito por meio do Portal de Transparência, porém de forma pulverizada entre as secretarias e órgãos municipais, ou seja, para saber o montante das despesas de comunicação do município o cidadão precisa consultar a base de dados de cada órgão, confrontando com o código da dotação orçamentária de publicidade ou, conhecedor da informação de que o GCS ao centralizar a gestão do orçamento de comunica- 
ção licitou os serviços de publicidade, que passaram a ser realizados de forma exclusiva por uma agência especializada e assim fazer a consulta por despesa paga à agência, uma vez que o portal permite a consulta dos valores empenhados por fornecedor. Sendo este o procedimento adotado pela pesquisa para chegar aos dados apresentados no tópico de estrutura e orçamento.

Importante destacar a impossibilidade de, via portal da transparência, o cidadão enxergar o recorte das despesas específicas decorrentes da contratação do serviço de compra de espaço publicitário em veículos (anúncios pagos). Essa limitação na apresentação do nível da despesa impede, por exemplo, que o pesquisador consiga distinguir os empenhos de publicidade destinados especificamente para o pagamento dos anúncios nos veículos, representando um obstáculo aos que desejam acompanhar como se dá a distribuição do orçamento de publicidade na mídia local.

Ainda em relação ao orçamento, vale destacar que o montante das despesas de publicidade empenhado para a Agência Centro de Comunicação Ltda. no ano de 2014 superou em R\$1,8 milhão o total das despesas empenhado no mesmo período pela área de Assistência Social. Essa comparação dimensiona a magnitude do orçamento de comunicação pública na administração pública municipal e leva a questionamentos quanto aos mecanismos de controle social sobre os investimentos e decisões dos gestores responsáveis pela comunicação pública no município de Porto Alegre. Ainda em termos de comparação pode-se afirmar que a área de Assistência Social, conta com política nacional e diretrizes nacionais estabelecidas pelo SUAS (Sistema Único de Assistência social), que determina uma série de mecanismos de prestação de contas, participação e controle social, enquanto a área de comunicação, conforme demonstrado no histórico, ainda busca regulamentação do capítulo constitucional que trata do tema.

Dentre os mecanismos de controle social para o setor de comunicação previstos na Constituição Federal destaca-se a efetivação dos conselhos nacional, estaduais e municipais de comunicação social. 
Nesse ponto Porto Alegre possui um histórico que revela a criação do Conselho Municipal de Comunicação Social ainda em 1989, por meio do Decreto n. 9426 que criou o órgão, prevendo sua regulamentação por meio do Projeto de Lei Complementar enviado à Câmara Municipal em novembro de 2004 e retirado de tramitação em fevereiro de 2005, a pedido do Executivo Municipal. Em 2013 a Associação dos Profissionais de Comunicação da Prefeitura de Porto Alegre (Asscompoa) encaminhou pedido por intermédio da Comissão de Educação, Cultura, Esporte e Juventude para desarquivamento do referido Projeto de Lei visando sua atualização e nova tramitação pela casa. Ao contatar a Associação por meio de sua página em uma rede social em março de 2015, ela informou que recebeu resposta da comissão informando que de acordo com o regimento do legislativo municipal somente o autor do projeto possui autoridade para encaminhar a solicitação de desarquivamento da matéria, declarou ainda que o executivo foi consultado mas não manifestou seu posicionamento sobre tema.

Outros pontos levantados pela Asscompoa e que dizem respeito à governança interna e participação dos servidores (jornalistas, relações pública, fotógrafos e assistentes administrativos) na gestão, são a deficiência de pessoal efetivo e a concentração dos postos de comando ocupados por agentes políticos. O último concurso para provimento dos quadros foi realizado em 1999 e dentre as funções exercidas por estes profissionais somente a chefia da Equipe de Cerimonial e Protocolo (subordinada diretamente ao Gabinete do Prefeito) é atualmente exercida por uma servidora de cargo efetivo. Ressalta ainda que os avanços tecnológicos na última década ampliaram participação do segmento comunicação digital no setor público e que atualmente a área que trabalha as comunicações na plataforma digital da Prefeitura de Porto Alegre é composta inteiramente por servidores detentores de cargos comissionados.

No campo da gestão pública observa-se que as metas estabelecidas no contrato de gestão estão relacionadas ao esforço do Gabinete de Comunicação Social em incrementar a capacitação do quadro 
atual frente às novas tecnologias, o avanço da comunicação digital e da comunicação de massa, uma das metas refere-se ao conteúdo das mensagens jornalísticas, estabelecendo que pelo menos $50 \%$ das comunicações feitas no portal da prefeitura diga respeito a serviços prestados à municipalidade. Nenhuma forma de controle é percebida, no contrato de gestão, sobre a atividade de publicidade, assim como nenhuma forma de consulta e medição quanto à recepção da audiência (cidadãos) sobre mensagens institucionais, sobre a efetividade da estratégia de comunicação ou a medição da relação valores investimentos $\mathrm{x}$ objetivos das campanhas publicitárias. Observa-se, portanto, que apesar da disposição em acompanhar as premissas do reconhecido modelo de gestão gerencial voltado para qualidade total dos serviços públicos, implantado em 2005 e aprimorado ao longo de uma década de experiência, o Gabinete de Comunicação Social em sua participação atua sobre questões pontuais, de maneira não uniforme, carecendo de uma abordagem mais alinhada aos princípios de qualidade, transversalidade, territorialidade e governança, expressos no mapa estratégico da PMPA

\section{Considerações finais}

Ao analisar a relação entre os temas Democratização da Comunicação Social no Brasil e a Gestão da Comunicação Pública Municipal, o presente trabalho buscou investigar a origem das demandas dos movimentos sociais, aspectos históricos não resolvidos da pauta nacional e suas possíveis implicações no exercício da comunicação entre Estado e cidadãos e também como os investimentos de publicidade dos governos podem contribuir para manutenção da concentração e predomínio dos grandes grupos da mídia nacional e suas afiliadas locais.

As lacunas deixadas pela ausência de uma política pública de comunicação, cujas origens remetem à falta de regulamentação do capítulo V da Constituição Federal de 1988, dificultam a atuação dos responsáveis pela comunicação pública, que por mais de duas 
décadas convivem com as limitações de um setor regulado prioritariamente pelas forças de mercado, em meio à falta de um consenso em torno da pauta de democratização da comunicação social. A não resolução das questões centrais da agenda nacional, como a propriedade dos meios e a diversificação dos conteúdos veiculados, parece impedir o encaminhamento de outros pontos relevantes, tais como a criação de uma política nacional para a comunicação pública que estabeleça parâmetros para os investimentos em mídia (anúncios pagos) e demais despesas oriundas da comunicação entre Estado e cidadão, assim como a normatização e os desdobramentos dos princípios constitucionais da publicidade e impessoalidade.

Tampouco no campo teórico os profissionais de comunicação social encontram um consenso em torno do conceito, abrangência, princípios e responsabilidades da comunicação pública, um tema cujos estudos no Brasil são ainda recentes e não chegam a apresentar modelos de gestão voltados para a prática profissional nas diferentes esferas de governo.

A incipiência dos referenciais teóricos, somada ao ambiente de não regulamentação e às limitações do perfil profissional do comunicador-assessor, voltado a responder os questionamentos dos formadores de opinião, ação situada no nível tático operacional, parecem dificultar uma abordagem estratégica da gestão da comunicação pública, que ainda demonstra se posicionar como área de apoio às ações dos governos transitórios ao invés de política de Estado.

Nesse contexto carente de referencial prático e teórico, a experiência de um município de grande porte como Porto Alegre, que apresenta uma história de aderência aos mecanismos de participação popular, uma área de comunicação estruturada e responsável por um orçamento significativo e que adota um modelo de gestão focado no controle da qualidade dos serviços públicos, pode servir de balizador para indicar o estágio de desenvolvimento e as limitações da comunicação pública na esfera local. Tal enfoque representa um subsídio inovador nas discussões sobre o papel da gestão das despesas públicas de publicidade nos veículos de comunicação, questionadas de 
forma incisiva pelos grupos pró-regulamentação e democratização da mídia.

A pesquisa conclui que os temas Democratização da Comunicação Social no Brasil e a Gestão da Comunicação Pública Municipal apresentam relação de complementaridade tanto nas consequências percebidas pela carência de regulamentação da comunicação na gestão pública, quanto na oportunidade de contribuição dos municípios para as discussões da agenda nacional, a partir a experiência local e dos pontos de melhoria identificados na sua gestão. A convergência é outro aspecto percebido no estudo da relação entre os temas, uma vez que tanto as demandas de democratização da comunicação social quanto a necessidade de implementação de novas ferramentas de gestão caminham no sentido de ampliar o controle social sobre o orçamento público voltado para as ações de comunicação dos governos.

A descrição da atividade de comunicação no município de Porto Alegre permitiu identificar os pontos de fragilidade da gestão com as carências históricas da regulamentação do setor e a incipiência dos estudos sobre o tema comunicação pública no contexto democrático brasileiro. A busca por informações nos sites oficiais da prefeitura permitiu perceber que o nível de aderência, organização e aprofundamento do GCS em relação ao modelo de gestão gerencial mostra-se inferior ao apresentado por áreas que contam com diretrizes nacionais já estabelecidas, como os setores de saúde, educação e assistência social. Essa aparente superficialidade também pode estar associada a pouca familiaridade do comunicador público às práticas de gestão modernas e às limitações de sua formação original para o exercício da função de gestor público.

O estudo aponta a necessidade da gestão da comunicação pública em Porto Alegre ampliar, a partir do modelo de gestão já implantado, as práticas de governança para permitir maior participação das partes interessadas nas definições; disponibilização das receitas e despesas específicas de comunicação de forma unificada; disponibilização das instruções normativas e mapeamento dos fluxos de traba- 
Tho e adoção de indicadores de resultados e não apenas de esforço. Tais procedimentos vão ao encontro das determinações do modelo de gestão ao mesmo tempo que representam um avanço em direção às demandas dos movimentos pró-democratização da comunicação social, que no Rio Grande do Sul conforme demonstrado já conseguiram aprovar em 2014 uma lei na esfera estadual com potencial de gerar adaptações na forma como é feito o controle das despesas de publicidade.

A percepção sobre a relação de complementaridade e interdependência entre os temas Democratização da Comunicação Social e Gestão da Comunicação Pública Municipal foi confirmada na medida em que o segundo tema demonstrou ser impactado pela falta de regulamentação do primeiro que, por sua vez, sofre consequências econômicas oriundas da concentração das despesas de publicidade paga pelos governos.

Ao descrever a relação entre os temas centrais da pesquisa e analisar a prática da comunicação pública em nível municipal o trabalho espera contribuir para o entendimento de que a democratização da comunicação social no Brasil passa necessariamente pela atenção, revisão e construção de uma política pública setorial, cujos mecanismos de gestão alcancem a esfera local.

\section{Referências}

1a CONFERÊNCIA NACIONAL DE COMUNICAÇÃO, Caderno de Resoluções. Disponível em: <http://www.biblioteca. presidencia.gov.br/publicacoes-oficiais-1/catalogo/orgao-essenciais/secom/caderno-1a-cofecom-conferencia-nacional-de-comunicacao/view>. Acesso em 25 jul. 2014

ASSEMBLEIA LEGISLATIVA- RS. "Lei das Mídias" gaúcha é sancionada. Porto Alegre. Agência de Notícias, 26/05/2014. Disponível em htpp:// www.al.rs.gov.br/notícias. Acesso em 25 abr. 2015.

ASSEMBLEIA LEGISLATIVA- RS. Lei n. 14541, de 22 de maio de 2014. Institui a Política Estadual de Incentivo às Mídias Locais e Regionais no Estado do Rio Grande do Sul. Disponível em: <http://www.legisweb.com.br/legislacao/?id=270599>. Acesso em 25 abr. 2015. 
BACHRACH, Peter; BARATZ, Morton S. Duas faces do poder. Rev. Sociol. Polit., Curitiba, v. 19, n. 40, Oct. 2011.

BRANDÃO, Elizabeth Pazito, Conceito de Comunicação Púbica - 3a. edição. In: Jorge Duarte. (Org.). Comunicação pública: Estado, mercado, sociedade e interesse público. São Paulo: Atlas, 2012.

CÂMARA MUNICIPAL DE PORTO ALEGRE. Lei Orgânica do Município, Promulgada em 04 de abril de 1990. Disponível em: http://www.camarapoa. rs.gov.br/biblioteca/lei_org/LEI\%200RG\%C3\%82NICA.html. Acesso em 10 mar.2015

CAPES. Módulo Gestão Tributária. Abrantes, Luiz A.; Ferreira, Marco A. Florianópolis: CAPES, 2010. Disponível em: <http://www.sead.ufba.br/sites/sead.ufba.br/files/gestao_tributaria_gpm_miolo_online_2_edicao_0. pdf>. Acesso em 20 de abr. 2015.

CONSTITUIÇÃO FEDERAL DE 1988.

CONTROLADORIA GERAL DA UNIÃO. Consulta de informações sobre acesso à informação e transparência pública no Estado do Rio Grande do Sul. Disponível em: <http://www.cgu.gov.br/assuntos/transparencia-publica/brasil-transparente/mapa-transparencia/rio-grande-do-sul>. Acesso em 20 mar 2015.

COSTA, João Roberto Vieira da. Comunicação de interesse público: ideias que movem pessoas e fazem o mundo melhor. São Paulo: Jaboticaba, 2006.

DOMINGUES-DA-SILVA, Juliano Mendonça; BARR50S, Chalini Torquato Gonçalves de. O Que Significa "Democratização da Comunicação"? Limites e possibilidades de enquadramentos teóricos a partir de modelos de democracia. Revista Política Hoje, Vol. 22, n. 1, 2013.

DUARTE, Jorge. Comunicação Pública - Estado, mercado, sociedade e interesse público. São Paulo: Atlas, 2012.

FÓRUM NACIONAL PELA DEMOCRATIZAÇÃO NO BRASIL, Tese 1 - Conjuntura da Comunicação no Brasil. Disponível em: < http://fndc.org.br/ plenarias/xviii-plenaria-abril-2014/ > Acesso em: 25 jul. 2014.

FOSSATTI, Nelson Costa. Gestão da comunicação pública na esfera pública municipal. Porto Alegre: Sulina, 2006.

GUARESCHI, Pedrinho A..O direito humano à comunicação - Pela democratização da mídia. Petrópolis: Vozes, 2013. 
GODOY, Arilda Schimidt. Introdução à pesquisa qualitativa e suas possibilidades. Revista de Administração de Empresas. São Paulo: Fundação Getúlio Vargas, Escola de Administração de empresas, 1995.

HASWANI, Mariângela Furlan. Comunicação Pública - Bases e abrangências. São Paulo: Saraiva, 2013.

IBOPE. Mediabook 2014. Disponível em: <http://www.mediabook.ibope. com/>. Acesso em 25 mar. 2015.

LIMA, Venício A. Comunicação na Constituinte de 1987/88: a defesa dos velhos interesses. In: BASTOS, Vânia L; COSTA, Tânia M. (orgs). Dossiê "Constituinte: Temas e Análises". Caderno CEAC/UnB, Ano 1, n. 1. Brasília, 1987

LIMA, Venício A. de. Conselhos de comunicação social - A interdição de um instrumento de democracia participativa. Brasília. FNDC, 2013.

LIMA, Venício A. de. Quais critérios adotar? Observatório da Imprensa, 2013. Disponível em: http://observatoriodaimprensa.com.br/interesse-publico/_ed746_quais_criterios_adotar/ Acesso em: 20 abr. 2015.

LIMA, Venício A. de. Regular a mídia para democratizar a comunicação. Revista Teoria e Debate. n 95. São Paulo. Ed. Perseu Abramo, 2011.

MALANGA, Eugênio. Publicidade: uma introdução. São Paulo: Atlas, 1976. MELO, Ricardo. Comunicação e interesse público: a escuta popular na comunicação pública. Construindo uma nova política. Recife: Fundaj: Editora Massagana, 2004.

MESSIAS, Roberto B. Transparência e a desconcentração na publicidade do governo federal. Observatório de Imprensa, 2013. Disponível em: <http://www.observatoriodaimprensa.com.br/news/view/transparencia_e_a_desconcentracao_na_publicidade_do_governo_federals. Acesso em 24 abr 2015.

NOVELLI, Ana Lúcia. O papel institucional da comunicação pública para o sucesso da governança. ORGANICON, Revista Brasileira de comunicação Organizacional e Relações Públicas, ano 3, n. 4, $1^{\circ}$ semestre 2006.

PEREIRA, L. C. B. A reforma do Estado dos anos 90: lógica e mecanismos de controle. São Paulo: Lua Nova, 1998.

PREFEITURA DE PORTO ALEGRE. Governo Municipal Legislação Organizacional do Executivo Municipal de Porto Alegre, Porto Alegre, 2015. 
Disponível em http://www2.portoalegre.rs.gov.br/governo_municipal/. Acesso em 20 abr. 2015.

PREFEITURA DE PORTO ALEGRE. Manual Modelo de Gestão da Prefeitura de Porto Alegre, Porto Alegre, 2014. Disponível em http://www2. portoalegre.rs.gov.br/smpeo/default.php?p_secao=26. Acesso em: 20 abr. 2015.

PREFEITURA PORTO ALEGRE. Portal da Transparência. Disponível em $<$ <ttp://www2.portoalegre.rs.gov.br/transparencia/>. Acesso em 2 abr 2015

RODRIGUES, Theófilo Codeco Machado. A Constituição de 1988 e a comunicação: história de um processo inacabado de regulamentação. Revista Mosaico, São Paulo, ed.7, Jan 2014. Disponível em: <http://cpdoc.fgv.br/ mosaico/?q=editorial/edi\%C3\%A7\%C3\%A3o-n\%C2\%BA-7-ano-iv > Acesso em: 14 fev. 2015.

SANT'ANNA, Armando. Propaganda: teoria, técnica, prática. São Paulo: Pioneira, 1998.

SECOM/PR. Relatórios de Pesquisas da Secretaria de Comunicação da presidência da República. Brasília, 2015. Disponível em: http://www.secom.gov.br/atuacao/pesquisa/relatorios-de-pesquisas Acesso em: 20 mar. 2015.

SECOM/PR. Comitê de Negociação. Brasília, 2012. Disponível em: http:// www.secom.gov.br/orientacoes-gerais/midia/comite-de-negociacao . Acesso em 15 abr. 2015.

SILVA, Luiz Martins da, Comunicação Pública: estado, governo e sociedade. In: Brandão, Elizabeth; MATOS, Heloiza. MARTINS, Luiz. Algumas Abordagens em comunicação pública. Brasília: Casa das Musas, 2033.

SILVA, Luiz Martins. Publicidade do poder: poder da publicidade - 3a. edição. In: Jorge Duarte. (Org.). Comunicação pública: Estado, mercado, sociedade e interesse público. São Paulo: Atlas, 2012, p. 180 - 192.

VIOLIN, Tarso Cabral. A democratização da mídia no Brasil. Disponível em:http://blogdotarso.com/2014/10/23/a-democratizacao-da-midia-no -brasil/>. Acesso em 25 mar.2015. 


\title{
Os Serviços de Proteção Social do Município de Tramandaí: uma análise a partir das normativas legais
}

\author{
Valdionor Dada dos Santos 1 \\ Rafael Kruter Flores ${ }^{2}$
}

\section{Introdução}

A Assistência Social, direito do cidadão e dever do Estado, tem como marco fundamental a Constituição da República Federativa do Brasil de 1988, em que passou a ser reconhecida como política social. A partir desse momento a Assistência Social passou a compor o tripé do Sistema de Seguridade Social Brasileiro. Diferentemente da Seguridade Social, a Assistência Social deve atender a todo cidadão que dela necessitar, independente de contribuição, e de forma gratuita.

Em 7 de dezembro de 1993, foi aprovada a Lei no 8.742, a Lei Orgânica da Assistência Social (LOAS), que regulamenta o direito social a assistência social. Desde então, iniciou-se uma nova estruturação na política de assistência social no Brasil, voltada para a descentralização e para a participação social.

Em junho de 2004, foi apresentada no Conselho Nacional de Assistência Social (CNAS) a versão preliminar da Política Nacional de

Graduado em Administração pela Faculdade Cenecista de Osório - FACOS. Especialista em Gestão Pública Municipal, Universidade Federal do Rio Grande do Sul - UFRGS.

2 Professor e pesquisador da Escola de Administração e do Programa de Pós-Graduação em Administração da Universidade Federal do Rio Grande do Sul. 
Assistência Social (PNAS), que foi amplamente divulgada e discutida em todos os estados brasileiros, sendo aprovada durante a Reunião Descentralizada e Participativa do CNAS realizada em setembro do mesmo ano. A PNAS é fruto de diversos atores sociais empenhados em torná-la uma política pública de Estado, que pudesse seguir as diretrizes da Lei Orgânica da Assistência Social (LOAS). Com isso, tornou-se necessário a criação do Sistema Único de Assistência Social (SUAS).

O SUAS organiza-se através dos princípios da universalidade, da gratuidade, da intersetorialidade, da equidade e da integralidade da proteção social, que deve ser garantida através da oferta de provisões em sua completude, por meio do conjunto articulado de serviços, programas, projetos e benefícios assistenciais (BRASIL, 2012, p.2).

Para observância desses princípios, o SUAS tem como base de funcionamento a descentralização político-administrativa para os Estados, Distrito Federal e Municípios, com um comando das ações em cada esfera de governo. Com isso, as normas gerais e a coordenação da Assistência Social competem à União, enquanto a coordenação e a execução dos programas cabem às esferas estadual e municipal, bem como as demais entidades beneficentes e de assistência social, integradas ao sistema, garantindo que sejam respeitadas as diferenças e as características sociais e territoriais de cada localidade. Desse modo, o SUAS organiza os serviços socioassistenciais a partir de um modelo de gestão participativa, que articula esforços e recursos de todos os entes da federação para execução e financiamento da PNAS; e envolve diretamente as estruturas e marcos regulatórios nacionais, estaduais e municipais, tendo sua coordenação central realizada pelo Ministério do Desenvolvimento Social e Combate à Fome (MDS).

Diante dessas considerações, pode-se avaliar que desde a criação do SUAS, em 2005, a partir das deliberações da IV Conferência Nacional de Assistência Social e previsto na LOAS, a política de Assistência Social vem desenvolvendo um papel importante na mobilização e participação da sociedade, envolvendo inúmeras instâncias delibe- 
rativas, instituições, organizações e segmentos sociais. Entretanto, com a descentralização e o aumento da participação de órgãos representativos da sociedade, vem aumentando também a exigência e a demanda de ações impostas pelo MDS aos municípios.

No município de Tramandaí - RS, foi criado em 2001 o Plano Municipal de Assistência Social. Porém, foi em 2005, com a normatização da PNAS, que o município aderiu ao Sistema através da Gestão Básica, e passou a fazer parte do SUAS, recebendo recursos federais para realizar suas atividades e assim dando maior amplitude para o setor. A partir dessa adesão, o município passou a atuar conforme as normatizações criadas pelo MDS, inclusive com o risco de perder os recursos federais no caso de não cumprimento das normas.

Desde a implantação do SUAS, diversas mudanças vêm ocorrendo no setor, alterando a forma de atendimento aos cidadãos e fazendo com que surjam inúmeras exigências de adequação dos municípios. Além disso, com a implantação do SUAS, tenta-se respeitar cada vez mais o direito de assistência social, que já era previsto na Constituição Federal de 1988, e foi posteriormente regulamentada pela LOAS. Atualmente o município está atuando na Gestão Básica de Assistência Social, e futuramente poderá aderir à Gestão Plena, ampliando os tipos de atendimento e aumentando os recursos oriundos do Governo Federal. Entretanto, para isso, precisará que sua estrutura e ações atuais estejam sendo executadas plenamente dentro das normas e da legislação vigente no que tange à Assistência Social.

O presente trabalho apresenta os resultados de uma pesquisa apresentada ao Curso de Especialização em Gestão Pública Municipal a distância da Universidade Federal do Rio Grande do Sul. O objetivo da pesquisa foi conhecer a situação atual da gestão do SUAS na cidade de Tramandaí e verificar se ela está sendo executada conforme exigido nas normas criadas pelo MDS para atender as famílias em situação de vulnerabilidade e risco social. Para tanto, foram traçados os seguintes objetivos específicos: (a) verificar se as equipes de referência dos órgãos de Proteção Social, que compõem a gestão 
municipal do SUAS em Tramandaí, estão de acordo com a Norma Operacional Básica de Recursos Humanos do SUAS (NOB-RH/SUAS); (b) identificar se os programas federais executados pelos órgãos de Proteção Social do município estão dentro das normas do MDS; (c) analisar a estrutura física dos órgãos de Proteção Social que fazem parte da Secretaria de Desenvolvimento e Assistência Social de Tramandaí;

Para realização da pesquisa, foram analisadas as equipes de referência que trabalham atualmente nos órgãos que fazem parte da gestão do SUAS no município: Centro de Referência de Assistência Social (CRAS), Centro de Referência Especializado de Assistência Social (CREAS), Casa de Passagem da Criança e do Adolescente e o Órgão Gestor de Assistência Social. Posteriormente, foi aplicado um questionário aos coordenadores e profissionais técnicos dos órgãos de Proteção Socioassistencial pertencentes à Secretaria de Desenvolvimento e Assistência Social (SDAS) do Município. Este questionário foi desenvolvido com base nas normas da Assistência Social: NOB/ SUAS, NOB-RH/SUAS, Tipificação de Serviços Socioassistenciais e nas Orientações Técnicas de cada órgão. Nesta etapa, questionouse sobre as ações que são desenvolvidas atualmente no município, e também sobre como está a estrutura física em cada órgão. Com os dados obtidos foi possível fazer um comparativo entre a situação da gestão atual com o que está exposto nas normas e regulamentos instituídos pelo MDS.

O artigo está organizado em dois itens. No primeiro, apresenta os principais aspectos da Política de Assistência Social, com enfoque no processo de Gestão em nível municipal, conforme legislação federal. No segundo, apresenta, já como análise de dados, o setor de Assistência Social em Tramandaí, assim como os resultados da comparação da atual situação do município com o que é exigido nas normas operacionais do setor. Por fim, são tecidas considerações finais a respeito da atual situação da Gestão do SUAS em Tramandaí. 


\section{2 - 0 Sistema Único de Assistência Social}

Neste item são apresentados os principais aspectos da Política de Assistência Social, com ênfase no funcionamento do SUAS a Nível Municipal.

\section{1 - Níveis de gestão municipal do SUAS}

Em se tratando de gestão municipal do SUAS, existem três níveis: inicial, básica e plena. Atualmente o município de Tramandaí encontra-se no nível de Gestão Básica. Neste nível, o município assume a responsabilidade de organizar a proteção social básica, devendo prevenir situações de risco, desenvolvendo potencialidades e aquisições. Para realizar essas ações, o gestor local necessitará, entre outras medidas a serem adotadas, estruturar Centros de Referência de Assistência Social (CRAS) em áreas de maior índice de vulnerabilidade social, de acordo com o porte do Município.

\section{2 - Níveis de proteção socioassistencial}

As ações do SUAS são organizadas em dois tipos de proteção social, a Proteção Social Básica e a Proteção Social Especial. A primeira é destinada à prevenção de riscos sociais e pessoais, por meio da oferta de programas, projetos, serviços e benefícios a indivíduos e famílias em situação de vulnerabilidade social. A segunda destina-se a famílias e indivíduos que já se encontram em situação de risco e que tiveram seus direitos violados por ocorrência de abandono, maus-tratos, abuso sexual, uso de drogas, entre outros aspectos.

De acordo com o art. 6-C, incluído na Lei no 8.742/93 pela Lei no 12.435/2011 "As proteções sociais, básica e especial, serão ofertadas precipuamente no Centro de Referência de Assistência Social (Cras) e no Centro de Referência Especializado de Assistência Social (Creas), respectivamente, e pelas entidades sem fins lucrativos de assistência social". (BRASIL, 2011, p. 16). 


\section{3 - Órgão gestor municipal de assistência social e as equipes de referência}

As atividades de gestão do SUAS em Tramandaí são desenvolvidas pela Secretaria de Desenvolvimento e Assistência Social, tendo como gestor o Secretário Municipal. Esta atividade é de competência exclusiva do Poder Público, implicando no exercício de funções de coordenação, articulação, negociação, planejamento, controle, avaliação e fiscalização.

Para que essas ações sejam efetivas, o órgão gestor necessita de uma equipe que apresente condições de contribuir e desenvolver as competências municipais no âmbito do SUAS. Neste sentido, a NOB -RH/SUAS dispõe que "Para a adequada gestão do Sistema Único de Assistência Social - SUAS em cada esfera de governo, é fundamental a garantia de um quadro de referência de profissionais designados para o exercício das funções essenciais de gestão". (BRASIL, 2009c, p. 24).

A NOB-RH/SUAS determina a composição das equipes de acordo com a complexidade dos serviços em cada nível de proteção. Para execução das ações no âmbito da Proteção Social Básica, é feita a composição da equipe do CRAS. Já para a Proteção Social Especial as equipes de referência são formadas para realizar ações de Média e Alta Complexidade, tendo o CREAS como unidade pública responsável pela coordenação e articulação da proteção social especial de média complexidade. Já os abrigos institucionais, casas lar e casas de passagem têm as equipes constituídas para que sejam feitos atendimentos em pequenos grupos para a proteção social de alta complexidade. Além disso, é necessária uma equipe de referência para atendimento psicossocial, sendo vinculada ao órgão gestor.

\section{4 - Estrutura física}

Para realização das ações que fazem parte da Gestão Municipal do SUAS, tão importante quanto à composição da equipe de referência é a existência de uma estrutura física adequada, com espaços que 
proporcionem o atendimento com dignidade aos usuários, mantendo o sigilo e a privacidade dos mesmos.

O CRAS pode ser considerado a porta de entrada para os Serviços Socioassistenciais, portanto, torna-se fundamental a existência de uma estrutura que contribua para um acolhimento inicial e também possibilite o acompanhamento dos usuários e de suas famílias. Para os tipos de atendimento realizados no CREAS deve-se ter um local onde os usuários se sintam confortados e seguros de que são atendidos com dignidade e sigilo.

Quanto ao Abrigo, a estrutura física tem papel fundamental para a permanência dos usuários no local. Este espaço deve ter os aspectos de uma residência, pois em alguns casos os internos acabam ficando por um período considerável de tempo até que sua situação seja resolvida, conforme descrito nas Orientações Técnicas dos Serviços de Acolhimento. "O serviço deve ter aspecto semelhante ao de uma residência e estar inserido na comunidade, em áreas residenciais, oferecendo ambiente acolhedor e condições institucionais para o atendimento com padrões de dignidade" (BRASIL, 2009b, p. 68).

\section{5 - Serviços desenvolvidos em cada nível de proteção}

Para a realização de um trabalho que possa atender a todos que precisam ser assistidos pela política de assistência social, é necessário um conjunto de serviços, que deverão ser prestados pelos órgãos de assistência, de acordo com cada nível de proteção social.

\subsection{1 - Serviços de proteção social básica}

As ações desenvolvidas pelo CRAS têm papel fundamental na efetivação da proteção social básica da assistência social. As ações dessa unidade pública estão regulamentadas pela Tipificação Nacional dos Serviços Socioassistenciais de 2009, que define como serviços a serem desenvolvidos pelo CRAS e/ou pela parceria com entidades que compõem a rede SUAS, os seguintes serviços: Serviço de Prote- 
ção e Atendimento Integral à Família (PAIF), Serviço de Convivência e Fortalecimento de Vínculos e Serviço de Proteção Social Básica no Domicílio Para Pessoas com Deficiência e Idosas.

Deste modo, entende-se que o CRAS tem caráter preventivo, requerendo que suas ações sejam executadas de forma antecipada junto aos fatores que promovem as situações de vulnerabilidade e risco social.

\subsection{2 - Serviços de proteção social especial}

Conforme a Tipificação Nacional de Serviços Socioassistenciais de 2009, o CREAS pode ofertar os seguintes serviços na proteção social de média complexidade: Serviço de Proteção e Atendimento Especializado a Famílias e Indivíduos (PAEFI); Serviço Especializado em Abordagem Social; Serviço de Proteção Social a Adolescentes em Cumprimento de Medida Socioeducativa de Liberdade Assistida (LA), e de Prestação de Serviços à Comunidade (PSC); Serviço de Proteção Social Especial para Pessoas com Deficiência, Idosas e suas Famílias; Serviço Especializado para Pessoas em Situação de Rua.

Já na proteção especial de alta complexidade, os serviços oferecidos podem ser: Serviço de Acolhimento Institucional, nas modalidades abrigo institucional, Casa-Lar, Casa de Passagem, Residência Inclusiva; Serviço de Acolhimento em República; Serviço de Acolhimento em Família Acolhedora; Serviço de Proteção em Situações de Calamidades Públicas e de Emergências.

\section{3 - Apresentação de dados e análise dos resultados}

Neste item são analisados os dados obtidos durante as pesquisas. Os dados foram analisados de acordo com o atual nível de gestão e com o porte do município. Atualmente, o município de Tramandaí enquadra-se no nível de gestão básica, sendo considerado um município de pequeno porte II. 


\section{1 - Análise das equipes de referência dos órgãos pertencentes ao SUAS}

As equipes de referência analisadas são as que pertencem à Secretaria de Desenvolvimento e Assistência Social (SDAS) e compõem a gestão do SUAS de acordo com cada nível de proteção existentes em Tramandaí.

Inicia-se a análise através da equipe de referência do CRAS, que pertence ao nível de proteção básica. Para um município do porte de Tramandaí exige-se no mínimo três técnicos de nível superior, sendo dois profissionais assistentes sociais e preferencialmente um psicólogo, três técnicos nível médio e um coordenador de nível superior, todos servidores efetivos.

Verifica-se primeiramente que o município conta com os profissionais de nível superior, e os mesmos contemplam as exigências da NO$\mathrm{B}-\mathrm{RH} / \mathrm{SUAS}$ quanto à escolaridade, entretanto, apenas os assistentes sociais são servidores efetivos, sendo que o psicólogo atua através de um contrato temporário, o que pode ocasionar maior rotatividade, se comparado a um servidor efetivo. Conforme Orientações Técnicas do CRAS, "a baixa rotatividade é fundamental para que se garanta a continuidade, eficácia e efetividade dos serviços e ações ofertados no CRAS, bem como para potencializar o processo de formação permanente dos profissionais". (BRASIL, 2009a, p. 61).

Já ao analisar os técnicos de nível médio, verifica-se que existem dois técnicos, quando a NOB-RH/SUAS orienta para que sejam três profissionais desse nível. Esperava-se que existissem ao menos os três exigidos, já que conforme as Orientações Técnicas do CRAS, além das atividades administrativas, estes profissionais também realizam outras atividades, como por exemplo, atividades de mediação de processos grupais e participação de reuniões sistemáticas de planejamento com a equipe de referência do CRAS.

Talvez o dado mais agravante neste caso seja a falta de um coordenador para o CRAS. Isso aumenta as responsabilidades do gestor municipal, já que a organização dos serviços é função do coordena- 
dor e na falta dele o gestor passa a ter que atuar com maior frequência junto ao CRAS, podendo prejudicar as atividades de gestão.

A continuidade da análise dá-se pela equipe do CREAS, que é o responsável pela execução dos serviços pertencentes ao nível de proteção social especial de média complexidade. Neste caso exige-se os seguintes profissionais: um coordenador, preferencialmente de nível superior, um assistente social, um psicólogo, um advogado, dois profissionais de nível superior ou médio para abordagem dos usuários e um auxiliar administrativo, todos efetivos.

A análise da equipe do CREAS inicia-se pela coordenação. Atualmente essa função é exercida por um profissional efetivo de nível médio, que recebe uma Função Gratificada (FG) para isso. Quanto ao Assistente Social e o Psicólogo, o CREAS possui esses profissionais conforme exigido na NOB-RH/SUAS, inclusive com um Assistente Social a mais do que exigido. Entretanto, em relação ao advogado, não existe este profissional para atender as famílias que necessitam de orientação jurídico-social. As situações vivenciadas pelos indivíduos e famílias atendidas no CREAS são complexas, tornando necessária a formação de uma equipe preparada e com todos os níveis de conhecimento necessários para um bom atendimento aos usuários.

Nesta análise, um fator que pode influenciar no andamento do trabalho do CREAS, é que não existe nenhum profissional para abordagem aos usuários. A falta destes profissionais pode acarretar no aumento da demanda de trabalho para os demais, já que a abordagem é fundamental, principalmente quando se trata da erradicação do trabalho infantil e da busca ativa de moradores de rua. Além disso, o auxiliar administrativo também não está de acordo com a NOB-RH/ SUAS, pois não é um servidor efetivo, e sim um cargo comissionado.

Prosseguindo a análise, avalia-se a equipe da Casa de Passagem, onde atualmente são atendidos apenas quatorze internos, crianças e adolescentes. Este é o local onde são realizados os atendimentos às famílias e indivíduos que por algum motivo necessitaram de acoIhimento fora do seu núcleo familiar. Neste caso a equipe mínima exigida consiste em: um coordenador, com nível superior ou médio, 
um cuidador para cada dez usuários, por turno, servidor de nível médio e qualificação específica e um auxiliar de cuidador para cada dez usuários, servidor de nível fundamental com qualificação específica.

A coordenação da casa é exercida por um profissional de nível médio, monitor, pertencente ao quadro de servidores efetivos da prefeitura, estando de acordo com o exigido na NOB-RH/SUAS. O serviço de cuidador, especificado na norma, é executado por seis monitores que se dividem em plantões. Nota-se a dificuldade de considerar um número adequado de servidores para este local, tendo em vista a incerteza de quando e de quantos usuários podem entrar na casa. Porém, pode-se afirmar que existe uma defasagem de profissionais no local, considerando que não existem atualmente auxiliares de cuidadores, conforme consta na NOB-RH/SUAS, fazendo com que durante as folgas e férias de algum servidor a sobrecarga de trabalho aumente para os demais. Cabe ressaltar que existe uma Assistente Social atuando na casa, porém na NOB-RH/SUAS consta que esse trabalho pode ser realizado por profissional pertencente ao órgão Gestor.

A seguir é feita a análise da equipe de referência para atendimento psicossocial vinculada ao Órgão Gestor, que tem como uma das funções contribuir no acompanhamento dos internos na casa e das respectivas famílias, e deve contar com no mínimo um Assistente Social e um Psicólogo, ambos servidores efetivos.

O Órgão Gestor possui uma Assistente Social no seu quadro de servidores, entretanto essa profissional não é concursada, mas comissionada. A questão mais preocupante é que não existe um psicólogo, e o acompanhamento aos internos da Casa de Passagem, que seria função dele, é realizado pelo psicólogo do CREAS, que pode ficar com sobrecarga de trabalho, podendo ocasionar falhas e carências nos atendimentos do seu órgão de origem.

Tendo em vista os dados analisados acima, acredita-se haver um longo caminho a ser percorrido para que o município tenha suas equipes de referência adequadas aos serviços, conforme exigido na NOB-RH/SUAS. Alguns pontos precisam ser verificados com atenção 
pelo poder público, entre os principais estão a falta de profissionais e a ocupação de alguns cargos por cargos comissionados, onde deveriam ser ocupados por servidores efetivos.

\section{2 - Análise das ações desenvolvidas dentro dos níveis de proteção socioassistencial, no âmbito do SUAS, em Tramandaí}

A análise desse subitem tem como foco visualizar os serviços desenvolvidos no município, de acordo com as normas federais. Os dados foram coletados através de questionário respondido pelos responsáveis por cada órgão. Além de questionar os respondentes a respeito da realização do serviço no município, também foram questionadas quais as principais ações e principais dificuldades para a realização dos serviços.

\subsection{1 - Serviços de proteção social básica}

A análise inicia pelos serviços de proteção social básica. Por não haver coordenação atualmente, conforme NOB-RH/SUAS, O questionário referente a esta etapa foi respondido pelas assistentes sociais do CRAS, que é o órgão onde devem ser ofertados estes serviços.

O primeiro serviço a ser analisado é o Serviço de Proteção e Atendimento Integral à Família (PAIF). Este serviço é realizado no CRAS e as principais ações para a sua execução consistem no acolhimento, na realização de oficinas com as famílias, nas ações comunitárias e encaminhamentos das famílias ou membros para os demais serviços da rede socioassistencial e de outros setores, como por exemplo, a saúde. Entre os principais problemas citados estão a ausência de profissionais direcionados para o SUAS e a falta de disponibilização de veículo para a acolhida domiciliar.

Para dar prosseguimento a análise, questiona-se a respeito do Serviço de Convivência e Fortalecimento de Vínculos. Este serviço também é realizado em Tramandaí, no CRAS. As principais ações são oficinas voltadas ao público adulto/idosos, crianças e adoles- 
centes com o objetivo da convivência. Novamente foram citados os problemas da falta de profissionais e da falta de disponibilização de veículos. Também foi citada a não realização de oficinas durante o verão, tendo em vista que os oficineiros são contratados apenas para o período do inverno.

O terceiro serviço analisado é Serviço de Proteção Social Básica no Domicílio Para Pessoas com Deficiência e Idosas. Diferentemente dos outros dois, este serviço não é executado em Tramandaí, portanto em desacordo com as orientações do MDS. A não execução do mesmo causa uma grande preocupação, já que o público que deveria ser atendido por ele talvez seja o que tenha maior dificuldade de acesso aos seus direitos, que são as pessoas com deficiência e os idosos. Foram citados como principais problemas para a não execução deste serviço o número restrito de profissionais para atender a grande demanda das outras ações e a falta de preparo e qualificação dos serviços do município para esta ação.

Acredita-se que mesmo que os dois primeiros serviços analisados estejam sendo executados, os apontamentos feitos pelos profissionais podem comprometer seriamente a eficiência do trabalho. A disponibilização de veículos se faz necessário pela extensa base territorial de Tramandaí, o que dificulta o acesso aos serviços por parte das pessoas que moram em zonas mais afastadas e que acabam não recebendo o devido acompanhamento. Já, o terceiro item analisado, faz com que a sua não execução deixe um público muito importante sem os atendimentos de prevenção de agravos que, se não acompanhados, podem provocar piores danos mais tarde.

\subsection{2 - Serviço de proteção especial de média complexidade}

Nesta etapa a análise é feita com base nos serviços que devem ser ofertados no CREAS, de acordo com o questionário que foi respondido pela coordenação do órgão.

Inicia-se a análise pelo Serviço de Proteção e Atendimento Especializado a Famílias e Indivíduos (PAEFI). O mesmo é executado no CREAS, conforme exigido pelo MDS. As principais ações desenvol- 
vidas para a realização deste serviço são as entrevistas de acolhida, atendimento psicossocial, organização de eventos com ações de mobilização e enfrentamento às violações de direitos, encaminhamento para a rede socioassistencial, visitas domiciliares e a articulação com a rede. Os principais problemas citados, que dificultam o trabalho, são a falta de veículos e falta de profissionais, opção que já havia ficado claro na análise das equipes de referência.

O próximo serviço analisado é o Serviço Especializado em Abordagem Social. Este também está sendo executado no CREAS, tendo como principais ações as saídas para abordagens noturnas, e como maiores problemas a falta de veículo próprio e a falta de profissionais para esse fim. Esperava-se que estas abordagens ocorressem durante o dia também, já que em casos como, por exemplo, a busca ativa para tentar identificar a incidência de trabalho infantil, a probabilidade de ocorrer casos deste tipo durante o dia é muito grande.

O Serviço de proteção social a adolescentes em cumprimento de medida socioeducativa de Liberdade Assistida (LA) e de Prestação de Serviços à Comunidade (PSC), também está sendo executado em Tramandaí, no CREAS. Segundo a coordenação do CREAS, as principais atividades desenvolvidas para a realização deste serviço são as entrevistas de acolhida, o atendimento e acompanhamento, as visitas domiciliares e a articulação com a rede. As dificuldades apontadas foram encontrar locais que acolham os adolescentes para cumprir as medidas de prestação de serviços à comunidade, necessidade de ampliação da equipe e as dificuldades em acessar a rede socioassistencial para encaminhamentos, o que pode fazer com que o serviço seja executado de forma incompleta.

O Serviço de Proteção Social Especial para Pessoas com Deficiência, Idosas e suas Famílias também é realizado em Tramandaí, no CREAS, conforme exigido pelo MDS. Entretanto para este caso, não se observou alguma ação efetiva que atendesse um dos principais objetivos das ações deste serviço, que segundo Brasil (2009c, p. 26) é "possibilitar a ampliação da rede de pessoas com quem a família do dependente convive e compartilha cultura, troca vivências 
e experiências", ações estas que contribuem para a inclusão social dos usuários e de suas famílias. As principais ações citadas foram as entrevistas de acolhida, os atendimentos psicossociais e as visitas domiciliares, e o principal problema foi novamente a falta de profissionais para comporem a equipe de referência.

Para finalizar a análise dos serviços de proteção especial de média complexidade, foi verificado o Serviço Especializado para Pessoas em Situação de Rua. Este serviço está sendo oferecido em Tramandaí, também pela equipe do CREAS, tendo como principais ações as abordagens noturnas, as entrevistas de acolhida, o atendimento psicossocial, a elaboração de relatórios e os encaminhamentos para rede socioassistencial. Entre os problemas citados estão a necessidade de ampliação da equipe de trabalho, a falta de compreensão da comunidade em geral e das autoridades sobre o tema e a dificuldade para acessar a rede socioassistencial para alguns encaminhamentos. Entende-se que esta dificuldade de acesso à rede é o principal motivo que faz com que não seja cumprido um dos principais objetivos do serviço, que é possibilitar condições de acolhida na rede socioassistencial.

De maneira geral, observa-se um grande esforço da equipe de referência do CREAS na tentativa de executar os serviços de acordo com as normas do MDS. Um fato positivo é que todos os serviços exigidos pelo MDS, mesmo que com muitas carências, já estão em funcionamento, o que já se pode ser considerado um grande passo tendo em vista que o CREAS está em funcionamento a menos de quatro anos. Entretanto, fica claro que a falta de profissionais para compor a equipe de referência influencia diretamente no trabalho, causando uma sobrecarga aos profissionais que trabalham atualmente na equipe, e prejudicando o acompanhamento das famílias e indivíduos.

\subsection{3 - Serviço de proteção social especial de alta complexidade}

Nesta etapa, é feita a análise dos serviços de proteção social de alta complexidade, que visa atender as famílias e indivíduos que se encontram em situação de abandono, ameaça ou violação de direi- 
tos, necessitando de acolhimento provisório, fora de seu núcleo familiar de origem. Neste caso o questionário foi respondido pela coordenadora da Casa de Passagem em conjunto com o Gestor municipal.

Inicia-se a análise pelo Serviço de Acolhimento Institucional. Atualmente Tramandaí possui apenas o acolhimento para crianças e adolescentes, realizado na Casa de Passagem da Criança e do Adolescente. Hoje o Município não conta com abrigo institucional para adultos e famílias, para idosos, para mulheres em situação de violência e nem para pessoas com deficiência, conforme exige o MDS.

A falta destes abrigos prejudica todo o trabalho da rede socioassistencial. Em caso de violência sexual, por exemplo, se a vítima procurar ajuda e for atendida, posteriormente ela deveria ser encaminhada para um abrigo. Não havendo este abrigo, corre-se o risco de ela ter que voltar para próximo ao agressor, colocando-a em situação de ameaça novamente. Portanto, observa-se que o município não está de acordo com o exigido pelo MDS, necessitando de grandes avanços para poder ter uma rede socioassistencial forte.

A análise a seguir trata do Serviço de Acolhimento em República, que não é executado em Tramandaí, causando um grande prejuízo para, por exemplo, o CREAS, que ao atender os moradores de rua não tem para onde encaminhá-los, caso os mesmos tenham interesse, o que pode ocasionar muitas vezes e perda de vínculo com este usuário e a descontinuidade do atendimento.

O Serviço de Acolhimento em Família Acolhedora também não é realizado em Tramandaí, contribuindo para que o município não esteja dentro das normas do MDS. Este serviço tem um papel importante para que crianças e adolescentes, afastados de suas famílias de origem por medida de proteção, mantenham uma convivência comunitária, o que pode contribuir em vários fatores para quando de um possível retorno a sua família.

Outro serviço que não está de acordo com as normas é o Serviço de Proteção em Situações de Calamidade Pública e de Emergência. Este serviço atualmente é executado pela Secretaria de Planejamento, e não por unidades referenciadas ao órgão gestor da Assistência Social, 
conforme deveria. É importante que seja realizado por órgãos vinculados a Assistência Social, devido ao fato de que estes órgãos já têm um cadastro e um acompanhamento das famílias mais carentes do município, o que pode contribuir para um atendimento mais eficiente numa possível situação de emergência ou calamidade pública.

Por fim, observa-se que os Serviços de Proteção Especial de Alta Complexidade precisarão de atenção redobrada por parte do poder público para uma estruturação de acordo com as normatizações federais, para que tenham uma estrutura mínima e não prejudiquem o andamento dos demais serviços. Entende-se que a única unidade que está atendendo parcialmente de acordo com as normas é a Casa de passagem da criança e do Adolescente.

\section{3 - Análise da estrutura física dos órgãos de proteção social de Tramandaí}

Neste último subitem a análise feita é da estrutura física dos órgãos de proteção social básica e de proteção social especial, de média e alta complexidade. Entende-se que a estrutura física, contribui diretamente na qualidade dos serviços prestados pelas equipes de referência. Os dados foram coletados através do preenchimento de um questionário pela coordenação de cada órgão. No caso do CRAS, que atualmente não tem coordenador, o questionário foi respondido pelas assistentes sociais.

Inicia-se a análise pela estrutura física do CRAS, que conforme o as Orientações Técnicas do CRAS (2009), deve contar com no mínimo uma recepção, uma sala de atendimento, uma sala de uso coletivo para trinta pessoas, uma sala administrativa, uma copa e um conjunto com quatro banheiros, sendo dois adaptados.

Neste caso pode-se verificar que a estrutura atual do CRAS está de acordo com as exigências do MDS, tendo como único ponto pendente a falta de um banheiro adaptado, sendo que o CRAS conta com apenas um, quando que o exigido são dois, um feminino e um masculino. 
Além dos dados coletados acima, também foi verificado que o imóvel é do próprio município e não é compartilhado com nenhum outro órgão. Estes dois fatores são muito importantes, especialmente o fato de o imóvel não ser alugado, o que facilita para que ele se constitua como referência para as famílias e indivíduos que dele necessitarem.

O prosseguimento da análise dá-se pela estrutura física do CREAS, que deve contar com no mínimo uma recepção, três salas de atendimento individual e familiar, uma sala para atividades em grupos, com capacidade para quinze pessoas, uma sala específica para uso da coordenação, equipe técnica ou administração, dois banheiros adaptados, uma copa ou cozinha, um espaço externo para atividades e um almoxarifado ou similar.

A análise dos dados mostra que das três salas exigidas, o CREAS conta com apenas duas, o que faz acreditar que numa hipótese de necessidade de todos os profissionais técnicos precisarem fazer atendimentos ao mesmo tempo, faltaria sala para algum deles.

Outro quesito que não está de acordo é a falta de uma sala específica para uso da coordenação, equipe técnica ou administração. A falta dessa sala pode ocasionar várias dificuldades para a equipe, como por exemplo, a dificuldade para elaboração de relatórios, para a realização de reuniões da equipe e também a dificuldade de arquivar os documentos das famílias atendidas, que necessitam de segurança e sigilo.

Pessoas com mobilidade reduzida podem ser atendidas no CREAS, portanto, um dos principais problemas verificados na estrutura deste centro é a falta de banheiro adaptado, nota-se que nenhum dos dois banheiros existentes possui adaptações para pessoas que possam precisar, sendo que são orientados dois banheiros adaptados.

Observa-se também a falta de um espaço externo para a realização de atividades. Esperava-se um espaço que proporcione o convívio entre os usuários e também permita a realização de algumas atividades coletivas, abertas à comunidade. Entretanto, nota-se que 
os demais espaços, como recepção, salas para atividades em grupo, cozinha e almoxarifado estão adequados as exigências do MDS.

Além dos dados acima, também foi questionado a respeito da situação do imóvel, onde foi verificado que neste caso ele é alugado. Além disso, também foi verificado que o imóvel não é compartilhado e que o prédio possui acessibilidade. Portanto, nota-se que destes três itens, apenas o fato do local ser alugado que não está dentro das normas. Assim como no caso do CRAS, é importante que o espaço seja em imóvel próprio, pois este também é um centro que fica como referência para as pessoas atendidas, e sendo alugado, a possibilidade de mudança é muito maior do que se fosse estatal.

Para finalizar as análises das estruturas, observa-se os cômodos da Casa de Passagem da Criança e do adolescente, tendo como base o número atual de internos na casa, que é de quatorze, entre crianças e adolescentes. Neste caso são exigidos quatro quartos com capacidade para quatro pessoas ou mais, uma sala de estar ou similar, uma sala de jantar com espaço suficiente para acomodar os usuários, um ambiente adequado para estudo, três banheiros com chuveiro, uma cozinha, uma área de serviço, uma área externa para realização de atividades, uma sala para a equipe técnica, uma sala para coordenação e uma sala de reuniões.

Pode-se notar que a Casa de Passagem da Criança e do Adolescente está atualmente com apenas uma pendência a ser corrigida, tendo em vista as exigências do MDS. O único ponto que não existe atualmente na casa, é uma sala de reuniões, que é importante para a realização de reuniões com a equipe e com as famílias dos internos. Os demais cômodos são suficientes para o número de internos que estão frequentando a casa atualmente.

De maneira geral, nota-se que os órgãos de proteção estão se adequando as exigências do MDS, com exceção do CREAS, que além de ter o imóvel alugado, ainda precisa providenciar alguns itens que melhorem a qualidade no atendimento, que são os banheiros adaptados e a sala para uso da coordenação, da equipe técnica e da administração, além de no mínimo mais uma sala para atendimento individual. 


\section{Considerações finais}

Com base na análise das normas operacionais, da LOAS, da Tipificação Nacional de Serviços Socioassistenciais, nos cadernos de orientações técnicas de cada órgão de proteção socioassistencial, entre outros, conclui-se que a gestão do SUAS no município ainda está em estruturação. Apesar da notória dedicação por parte das equipes de referência para executar os serviços de acordo com as normas federais, nota-se que a estrutura organizacional do município, em alguns pontos, não tem contribuído para que as ações do SUAS sejam executadas na sua plenitude.

Quanto às equipes de referência, nota-se a falta de profissionais que conforme a legislação, deveriam compor as equipes, e que teriam um papel de extrema importância para o andamento do trabalho, como é o caso a falta de um coordenador no CRAS, do advogado e dos profissionais para abordagem social do CREAS, e dos auxiliares de cuidadores na Casa de Passagem da Criança e do Adolescente. Além da falta de profissionais, outro fator que não está dentro das normas, é a ocupação de cargos que deveriam ser de profissionais efetivos, preenchidos por CC's e por contratos temporários, o que possibilita uma maior rotatividade desses profissionais, podendo prejudicar a continuidade do trabalho.

$\mathrm{Na}$ análise dos serviços desenvolvidos em Tramandaí, observa-se a não realização de alguns deles, como é o caso Serviço de Proteção Social Básica no Domicílio Para Pessoas com Deficiência e Idosas, que deveria ser executado no CRAS; e dos Serviço de Acolhimento em República e Serviço de Acolhimento em Família Acolhedora, que pertencem ao Serviço de Proteção Especial de alta complexidade. Isso faz com que o Município, além de não estar dentro das normas, acabe tendo dificuldades para a realização dos demais serviços. Além disso, verifica-se que as principais dificuldades para o bom andamento do trabalho são a falta de disponibilização de veículos, falta de profissionais capacitados para compor as equipes de referência, entre outros. 
Já na análise da estrutura física, aponta-se esta como o ponto com menos itens negativos. O CRAS está de acordo com as normas do MDS, a Casa de Passagem conta com apenas uma pendência, que é a falta de uma sala de reuniões, e apenas o CREAS que precisa de uma maior atenção do gestor, pois este está em um imóvel alugado, sem banheiros adaptados e sem espaço externo para realização de atividades de convívio, além de ter uma sala de atendimento a menos do que o exigido nas normas.

Entende-se que para minimizar a carência de profissionais, o município precisaria criar concurso com cargos específicos para a assistência social, com escolaridade compatível com as necessidades dos serviços, evitando assim o uso de cargos comissionados e de profissionais contratados temporariamente. Além disso, precisa que sejam ampliadas as medidas de capacitação dos profissionais do SUAS, pois este é um sistema que vêm mudando com muita frequência, precisando de profissionais capacitados e atualizados com relação aos serviços.

Sugere-se também que o órgão gestor verifique a possibilidade de transferir para a Secretaria de Saúde os serviços de transporte de pacientes para os hospitais de Porto Alegre ou que faça uma reestruturação neste setor, já que foi verificado que os veículos ficam comprometidos com o transporte destes pacientes, e acabam não atendendo as equipes de referência, prejudicando os atendimentos e acompanhamentos dos usuários e famílias.

Quanto à estrutura física, sugere-se que se busque mecanismos para construção de um CREAS com recursos do município, com uma estrutura adequada, e enquanto isso não ocorre, sugere-se que seja procurado um novo local, com as condições mínimas exigidas, pois acredita-se que para justificar o aluguel deste prédio, o mesmo deveria ter uma estrutura mínima adequada para bem atender os usuários deste centro.

Por fim, conclui-se que a gestão do SUAS em Tramandaí tem vários pontos a serem corrigidos para atuar dentro das normas federais, como a melhoria nas condições de trabalho das equipes de referência, a ampliação e adequação destas equipes, a melhoria e 
a criação dos serviços que deveriam estar em funcionamento e não estão, a melhoria na estrutura física de alguns órgãos, entre outros, precisando de uma reestruturação em alguns setores. Entretanto, tendo em vista o pouco tempo de funcionamento do SUAS e as mudanças contínuas que vêm ocorrendo no setor, acredita-se que apesar das pendências, o município está no caminho certo, precisando resolver alguns detalhes que podem contribuir para consolidar os serviços existentes. A partir daí será possível projetar a criação dos novos serviços e programas, para futuramente aderir a Gestão Plena da assistência social. Esta, para ser colocada em prática, terá um longo caminho pela frente.

\section{Referências}

BRAGA, Léa Lúcia Cecílio. O trabalho de assistentes sociais no CRAS.In: O trabalho do assistente social no SUAS: seminário nacional/CFESS. Brasilia: CFESS, 2011. p. 142-154.

BRASIL. Constituição da República Federativa do Brasil. Brasília: Senado Federal, 1988.

BRASIL. Lei no 8742, de 7 de dezembro de 1993. Lei Orgânica da Assistência Social, alterada pela Lei 12.435/2011. Brasília, 2011 a.

BRASIL. Ministério do Desenvolvimento Social e Combate à Fome. Orientações técnicas para o Centro de Referência de Assistência Social (CRAS). Brasília, 2009a.

BRASIL. Ministério do Desenvolvimento Social e Combate à Fome. Orientações técnicas: serviços de acolhimento para crianças e adolescentes. Brasília, 2009b.

BRASIL. Ministério do Desenvolvimento Social e Combate à Fome. Orientações técnicas: Centro de Referência Especializado de Assistência Social - CREAS.Brasília, $2011 \mathrm{~b}$.

BRASIL. Norma operacional básica de recursos humanos do SUAS NOBRH/SUAS. Brasília: MDS, 2009c.

BRASIL. Política nacional de assistência social PNAS. Brasília: MDS, 2004. 
BRASIL. Resolução no 17 de 20 de junho de 2011. Brasília: Conselho Nacional de Assistência Social, 2011c.

BRASIL. Resolução no 33 de 12 de dezembro de 2012. Norma Operacional Básica do Sistema Único de Assistência Social - NOB/SUAS. Brasília: Conselho Nacional de Assistência Social, 2012.

BRASIL. Resolução no 109 de 11 de novembro de 2009: tipificação nacional de serviços socioassistenciais. Brasília: Diário Oficial da União, 2009d. COUTO, Rojas Berenice. $\mathbf{O}$ direito social e a assistência social na sociedade brasileira: uma equação possível? São Paulo: Cortez, 2004.

ROESCH, S. M. A. Projetos de estágio e de pesquisa em administração. São Paulo: Atlas, 1999.

SERRA, Rose M. Crise de materialidade no serviço social: repercussões do mercado profissional. São Paulo: Cortez, 2000. p. 159-186.

YAZBEK, Carmelita Maria. A gestão do SUAS. IN: Conselho Nacional de Assistência Social. Caderno de Textos - VI Conferência Nacional de Assistência Social. Brasília, 2007. 


\title{
A Importância da Apuração de Custos na Administração Pública Municipal
}

\author{
Vanderlei Rodrigues Schneider ${ }^{1}$ \\ Máris Caroline Gosmann²
}

\section{Introdução}

A apuração de custos no serviço público municipal é algo muito incipiente, apesar de prevista na legislação desde a Lei no 4.320, de 17 de março de 1964. Falta evidenciação nas informações, no sentido de mostrar como os gastos estão sendo efetuados, para que todos possam verificar a aplicação do recurso público. Isso não se refere à transparência na gestão ou na forma de divulgação dos custos dos serviços públicos, pois isso a Lei de Acesso à Informação já determina, mas sim à disponibilização da informação de maneira simples e compreensível a todos que dela dependam, seja para auxiliar na gestão ou para fiscalizar e controlar a aplicação dos recursos públicos. Atualmente, não se sabe quanto custa manter um aluno em sala de aula, se é melhor ofertar a vaga na rede pública ou adquiri-la da rede privada.

Segundo a Resolução do Conselho Federal de Contabilidade (CFC) no 1.366, de 25 de novembro de 2011, que aprova a Norma

Especialista em Gestão Pública Municipal pela UFRGS, Contador da Câmara Municipal de Vereadores de Bento Gonçalves/RS

2 Professora de Ciências Atuariais na Universidade Federal do Rio Grande do Sul (UFRGS). Atuária, Economista, Especialista em Economia e Finanças e Mestre em Ciências Atuariais 
Brasileira de Contabilidade Técnica (NBC T) 16.11 - Sistema de Informação de Custos do Setor Público, que é a mais recente norma a tratar do assunto, a implantação de sistemas capazes de medir os custos no setor público, de todos os entes da federação, deveria ocorrer a partir de janeiro de 2012. Cabe ressaltar que a apuração de custos, já determinação pela Lei no 4.320/1964, foi reforçada pela Lei Complementar no 101, de 4 de maio de 2000 (Lei de Responsabilidade Fiscal - LRF). Contudo, a implantação ainda não é realidade na maior parte dos municípios brasileiros.

O objetivo deste estudo foi saber se a apuração dos custos, por meio da implementação da contabilidade de custos, auxilia a fornecer informações como subsídio para a tomada de decisão, a fim de melhorar a gestão, para que os recursos sejam investidos de forma adequada e tenham sua avaliação realizada, permitindo à administração pública exercer o controle dos recursos disponíveis. Dessa forma, o foco do trabalho foi analisar como a apuração de custos pode auxiliar a ação governamental na redução de despesas, quais benefícios podem advir da gestão de custos e como as informações de custos podem auxiliar o gestor na tomada de decisão. Apresentaram-se vários aspectos que demonstram a importância da apuração de custos no serviço público municipal, que oportunizarão informações como suporte aos gestores, para uma eficiente e eficaz tomada de decisão. Para tal, foram mostrados alguns exemplos do município de Bento Gonçalves/RS para elucidar o tema.

A metodologia deste trabalho propõe a teoria de custos como ferramenta de gestão pública municipal. Foram analisados dados de dois setores do Município de Bento Gonçalves/RS, devendo ser ressaltado que os dados apresentados, referentes ao período de 2014, não foram disponibilizados pelo Município. Dessa forma, os valores exibidos na análise dos resultados foram obtidos por meio de atualização da tabela inicial de 2012 pelo Índice Geral de Preços - Mercado (IGP-M), que é o índice utilizado para atualização monetária de contratos por parte do Município.

Para esse fim, foram delineados os seguintes objetivos específicos: a) verificar de que forma a legislação determina sejam apurados 
os custos no serviço público municipal; b) identificar, com base nas normas contábeis e na legislação, o método de custeio mais adequado para ser utilizado na apuração dos custos do serviço público municipal; c) relacionar os tipos de informações que a apuração de custos traz e o reflexo dessas na gestão pública municipal.

Com o intuito de alcançar os objetivos propostos, este estudo empregou métodos de natureza descritiva. Trata-se, portanto, de um estudo descritivo com abordagem qualitativa e destacou-se pela forma como os dados foram apresentados, conforme Gil (2002). Foi baseado em pesquisa bibliográfica e documental, conforme Zanella (2009), utilizando-se de revisão da literatura, consulta a documentos, à normatização e à legislação vigentes sobre sistema e controle de custos.

Os dados, obtidos e coletados por meio de pesquisa bibliográfica e documental, são tipificados como secundários, e a análise se deu com base nas normas gerais de contabilidade, na legislação que regulamenta a implementação do sistema de apuração de custos, bem como nas normas internacionais que regem o sistema de informação de custos do setor público, aplicáveis no Brasil. Os dados secundários foram obtidos por meio de documentos públicos, legislação e bibliografia pertinentes ao tema, inclusive publicações contábeis e legais que norteiam a apuração de custos no setor público. Analisaram-se, em complemento, outras fontes de dados que auxiliam à apuração de custos no serviço público municipal, como a exibição de documentos e relatórios do município de Bento Gonçalves/RS.

Este capítulo está organizado em quatro partes. Na primeira, aborda-se aspectos da gestão pública de custos, apresentando as normas de contabilidade aplicadas ao setor público, o orçamento público e a relação destes com a contabilidade de custos e os sistemas de custos. Na segunda, a pesquisa bibliográfica é ampliada dando ênfase à legislação e às normas que regem a contabilidade de custos no setor público, apresentando os sistemas e métodos de custeio, sobre como a apuração de custos pode auxiliar a gestão municipal. Por fim, apresentam-se os resultados e as considerações do estudo. Finaliza-se com as referências. 


\section{1 - A Gestão Pública de custos}

A contabilidade pública, no Brasil utilizada como sinônimo da contabilidade governamental, vem sofrendo várias alterações nos últimos anos, com o objetivo de aprimorar o controle do patrimônio e proporcionar eficiência e eficácia, além de dar mais transparência à utilização dos recursos públicos. Dessa forma, nos próximos itens apresentam-se conceitos e definições sobre o campo de aplicação, as normas de contabilidade aplicadas ao setor público, sistema contábil e orçamento público, além de definições e objetivos da contabilidade pública.

Conforme Silva (2011) a contabilidade é a ciência que estuda as funções de orientação e controle relativas aos atos e fatos administrativos, sendo a contabilidade pública uma especialização voltada ao estudo e análise dos fatos administrativos que ocorrem em um campo de aplicação específico, definido como administração pública (grifo nosso).

Segundo a NBC T 16.1,

Contabilidade Aplicada ao Setor Público é o ramo da ciência contábil que aplica, no processo gerador de informações, os Princípios Fundamentais de Contabilidade e as normas contábeis direcionadas ao controle patrimonial de entidades do setor público (RESOLUÇÃO/CFC № 1.128/2008, item 3).

Para Silva (2011) a contabilidade aplicada ao setor público objetiva fornecer à administração informações sobre o registro, controle e acompanhamento das variações do patrimônio público; organização e execução dos orçamentos além do controle de custos e a eficiência do setor público; dentre outras. Conforme a NCB T 16.1,

O objetivo da Contabilidade Aplicada ao Setor Público é fornecer aos usuários informações sobre os resultados alcançados e os aspectos de natureza orçamentária, econômica, financeira e física do patrimônio da entidade do setor público e suas muta- 
ções, em apoio ao processo de tomada de decisão; a adequada prestação de contas; e o necessário suporte a instrumentalização do controle social, (RESOLUÇÃO/CFC № 1.128/2008, item 4).

Para Rosa (2011, p. 7) "o objeto da contabilidade pública é o patrimônio público, assim entendido como o conjunto de direitos e bens, tangíveis ou intangíveis, onerados ou não." Percebe-se, então, que o campo de aplicação da Contabilidade Aplicada ao Setor Público abrange todas as entidades do setor público e é o espaço de atuação do profissional de contabilidade que demanda estudo, interpretação, avaliação, registro e evidenciação de fenômenos contábeis, decorrentes de variações patrimoniais em entidades do setor público ou entidades que recebam, movimentem, ou apliquem recursos públicos (RESOLUÇÃO/CFC № 1.128/2008).

Em síntese, pode-se dizer que o campo de aplicação da contabilidade pública é o das entidades governamentais (União, Estados e Municípios) e seus órgãos de administração indireta, tais como fundos, autarquias, fundações e empresas públicas, que utilizam recursos do orçamento público.

\section{1 - Normas de Contabilidade Aplicadas ao Setor Público}

O Conselho Federal de Contabilidade (CFC) tem buscado priorizar a convergência das normas brasileiras aos padrões internacionais, inclusive no setor público. Desse modo, a contabilidade pública brasileira deixa de dar ênfase apenas aos aspectos orçamentários e passa, também, a se preocupar com a contabilidade patrimonial, reforçando os dispositivos constantes da Lei no 4.320/1964 de evidenciação do patrimônio. A convergência da contabilidade para as normas internacionais aplicadas ao setor público é o processo de uniformização de procedimentos para o desenvolvimento de sistemas contábeis harmônicos em nível mundial, buscando reduzir o efeito da diversidade de conceitos existentes sobre temas contábeis. 
Dessa forma, apresentam-se três Normas de Contabilidade (NBCASP) resultantes do processo de convergência:

- NBC T 16.1 - CONCEITUAÇÃO, OBJETO E CAMPO DE APLICAÇÃO;

- NBC T 16.2 - PATRIMÔNIO E SISTEMAS CONTÁBEIS;

- NBC T 16.11 - SISTEMA DE INFORMAÇÃO DE CUSTOS DO SETOR PÚBLICO.

A primeira norma define quem está abrangido no campo de aplicação da contabilidade aplicada ao setor público. A segunda traz como elementos úteis ao trabalho a inclusão das etapas de planejamento no subsistema de controle orçamentário e implementação do subsistema de custos. Por fim, a terceira norma, trata de regras básicas para a mensuração e evidenciação dos custos no setor público, apresentado como Subsistema de Informação de Custos do Setor Público - SICSP. A NBC T 16.1 já foi objeto de análise anteriormente. Segue-se com as da NBC T 16.2 e da NBC T16.11.

\section{2 - Sistema Contábil}

O sistema contábil, definido pela Resolução no 1.129, de 21 de novembro de 2008, que aprova a NBC T 16.2 - Patrimônio e Sistemas Contábeis,

representa a estrutura de informações sobre identificação, mensuração, avaliação registro, controle e evidenciação dos atos e fatos da gestão do patrimônio público, com o objetivo de orientar e suprir o processo de decisão, a prestação de contas e a instrumentalização do controle social (RESOLUÇAO/ CFC № 1.129/2008, item 10).

Conforme Rosa (2011), para que esse objetivo seja alcançado, a contabilidade aplicada ao setor público é organizada sob a forma de 
sistema de informações, cujos subsistemas devem estar integrados, para fornecer informação sobre o patrimônio público. Segundo a já referida resolução, o sistema contábil está estruturado nos seguintes subsistemas de informações: Subsistema orçamentário, patrimonial, de custos e de compensação.

O Orçamentário "registra, processa e evidencia os atos e os fatos relacionados ao planejamento e à execução orçamentária" (RESOLUÇÃO/CFC № 1.129/2008, item 12, alínea a). Dessa forma, ocorrem nesse subsistema os atos de natureza orçamentária, que consistem na aprovação e execução do orçamento, tanto nas receitas como nas despesas e também nos lançamentos de encerramento do exercício (ROSA, 2011).

O Patrimonial "registra, processa e evidencia os fatos financeiros e não financeiros relacionados com as variações qualitativas e quantitativas do patrimônio público" (RESOLUÇÃO/CFC № 1.129/2008, item 12, alínea c).

O Subsistema de Custos "registra, processa e evidencia os custos dos bens e serviços, produzidos e ofertados à sociedade pela entidade pública" (RESOLUÇÃO/CFC № 1.129/2008, item 12, alínea d). Diversos dispositivos legais dispõem sobre a determinação de custos no serviço público. Dessa forma, o subsistema de custos e todas as suas variáveis serão objeto de ampla análise, com mais detalhes e aprofundamento, no decorrer deste trabalho.

A implantação de um Sistema de Custos permitirá à Administração Pública exercer o controle da ação governamental, cujo resultado será obtido pela análise da eficiência da utilização dos recursos disponibilizados aos órgãos para execução dos programas de governo (ROSA, 2011, p. 392).

O Subsistema de Compensação "registra, processa e evidencia os atos de gestão cujos efeitos possam produzir modificações no patrimônio da entidade do setor público, bem como aqueles com funções específicas de controle" (RESOLUÇÃO/CFC № 1.129/2008, item 12, alínea e). Conforme Rosa (2011) todos os atos da Administração que 
afetem ou possam vir a afetar o patrimônio do ente no futuro são registrados nesse subsistema. Dessa forma, verifica-se que ele objetiva o controle de atos potenciais, como contratos e convênios, bem como a apuração dos custos da entidade.

\section{3 - Orçamento Público}

O objetivo de abordar o orçamento público é apresentar o modelo de planejamento e orçamento vigentes no Brasil, principalmente, no que diz respeito à classificação da despesa orçamentária. Cabe esclarecer que será enfatizada a classificação que deve ser utilizada pelos municípios quando da elaboração de suas peças orçamentárias.

Conforme Silva (2011), o orçamento é um ato preventivo e autorizativo das despesas que o Estado deve realizar em um exercício. É um conjunto de normas referentes à execução e ao controle das etapas do orçamento com a função de impor limites ao gestor ou responsável por aplicar (gastar) os recursos públicos, fazendo com que os gestores sigam, a princípio, o que foi aprovado nas leis orçamentárias. Alterações da previsão inicial são possíveis, contudo, devem ser objeto de análise do Poder Legislativo para ter validade. Baleeiro (2002) define orçamento público como o ato pelo qual o Poder Legislativo prevê e autoriza ao Poder Executivo, por certo período de tempo e, detalhadamente, as despesas destinadas ao funcionamento dos serviços públicos, bem como a arrecadação das receitas já criadas em lei. Na verdade, o que ocorre é que o Poder Executivo prevê o orçamento, visto que é de sua iniciativa, e o Poder Legislativo autoriza-o a executar as despesas, por determinado período de tempo.

Portanto, o orçamento público é um conjunto de leis que contém os programas e ações de um governo e estão vinculados às realizações deste, com os objetivos e metas a atingir, expressos na legislação, por meio de projetos e atividades que possibilitam o acompanhamento e a avaliação dos resultados (ROSA, 2011).

As Peças Orçamentárias são um conjunto de leis que estão previstos na Constituição Federal de 1988 (CF/88), no art. 165 e são leis de 
iniciativa do Poder Executivo: Plano plurianual (PPA), Lei de Diretrizes Orçamentárias (LDO) e Lei do Orçamento Anual (LOA) e, conforme Rosa (2011), tem por objetivo ser a base do planejamento, com vistas à melhor alocação dos recursos públicos.

Para Silva (2011), o PPA, a LDO e a LOA são componentes básicos do planejamento, que se subdivide em estratégico (PPA) e operacional (LDO e LOA). É por meio da LOA que os programas de governo articulam um conjunto de ações, como projetos e atividades, em que se busca a concretização de objetivos estabelecidos, visando atender às demandas da população. A seguir, descreve-se o que determina a CF/88 sobre cada uma dessas leis.

O PPA deverá ser instituído por lei para um período de 4 anos, que não coincide com o período do mandato do Chefe do Poder Executivo. "A lei que instituir o plano plurianual estabelecerá, de forma regionalizada, as diretrizes, objetivos e metas da administração pública federal para as despesas de capital e outras delas decorrentes e para as relativas aos programas de duração continuada" (Brasil, 1988, art. 165, parágrafo 1ํ).

A LDO compreenderá as metas e prioridades da administração pública federal e orientará a elaboração da lei orçamentária anual (BRASIL, 1988), sendo assim, o instrumento de formalização das políticas públicas e tem periodicidade anual. Nela estão especificadas as metas e prioridades da administração pública e será definida a estrutura e a organização da LOA (ROSA, 2011).

A LOA compreende o orçamento fiscal, o orçamento de investimentos e o orçamento da seguridade social (BRASIL, 1988), sendo assim, conterá a discriminação da receita e da despesa, que é apresentada em um quadro de dotações, que representam os programas, projetos e atividades do governo. Atualmente, o planejamento da ação governamental por meio da LOA está estruturado mediante programas, que são instrumentos de organização da ação do governo (ROSA, 2011).

Para Silva (2011), o processo de planejamento precede à elaboração do orçamento e tem como objetivo a seleção das alternativas 
para a ação governamental em consonância com os meios disponíveis. O processo de planejamento envolve os programas, projetos e atividades e, analisa-se a relação desses com custos na sequência.

A classificação atual da despesa orçamentária está alicerçada no plano de contas contábil. Isso permite analisar as despesas por várias perspectivas, como: institucional, funcional, programática, pela natureza da despesa e por fontes de recursos. Nesse sentido, destaca-se a classificação por programas, por esta representar ações de governo que possibilitam melhor visualização dos custos, sendo facilmente identificáveis pelas áreas contábil e de orçamento. A classificação por programas é a que mais possibilita analisar em que setores especificamente estão sendo aplicados os recursos públicos. Brasil (1999) e, por meio da Portaria no 42/1999, estabelece os conceitos, conforme descrito na sequência.

Programa é o "instrumento de organização da ação governamental que visa à concretização dos objetivos pretendidos, sendo mensurado por indicadores estabelecidos no plano plurianual" (ROSA, 2011, p. 120). Para Silva (2011), é o instrumento de organização da atuação do governo que articula um conjunto de ações que concorrem para a realização de um objetivo comum preestabelecido, mensurado por indicadores instituídos no plano, visando ao atendimento de determinada necessidade ou demanda da sociedade.

Projeto é o "instrumento de programação para alcançar o objetivo de um programa, que envolve um conjunto de operações, limitadas no tempo, das quais resulta um produto que concorre para a expansão ou o aperfeiçoamento da ação de governo" (ROSA, 2011, p. 120).

Atividade é o "instrumento de programação para alcançar o objetivo de um programa, que envolve um conjunto de operações que se realizam de modo contínuo e permanente, das quais resulta um produto necessário à manutenção da ação de governo" (ROSA, 2011, p. 120).

Dessa forma, na elaboração das ações de governo - que são instrumentos definidos no PPA com o propósito de atender às demandas da sociedade - estas são discriminadas por programas, projetos e atividades, possibilitando maior controle social sobre as políticas 
públicas e, também, a evidenciação dos custos e os impactos dos planos de governo.

\section{4 - Contabilidade de custos}

A contabilidade de custos passou a ser encarada como uma eficiente forma de auxílio no desempenho gerencial. Possui função relevante fornecendo dados à administração, auxiliando no controle e na tomada de decisão (VICECONTI; NEVES, 2013). O auxílio ao controle fornece dados para estabelecer padrões e orçamentos, dentre outros. No que se refere à decisão, consiste em suprir de informações relevantes que têm consequências no curto e no longo prazos, sobre medidas de introdução ou corte de produtos, opção de compra ou produção própria (MARTINS, 2010).

Analogamente, na esfera pública, a contabilidade de custos pode suprir os gestores com informações que auxiliam na introdução ou corte de um serviço ou, por exemplo, auxiliar na decisão de aquisição de serviços educacionais ou a construção de escolas de educação infantil, ou ainda, na aquisição de serviço de transporte escolar ou a aquisição de ônibus para esse fim. Cabe esclarecer que algumas atividades devem essencialmente ser exercidas pelos entes públicos. Estas são as denominadas atividades-fim em que o ente público é o responsável pela prestação desses serviços à sociedade, não podendo formalizar parcerias nem terceirizar esse serviço.

Dessa forma, percebe-se que com o auxílio da contabilidade de custos é possível a apuração e o controle dos custos com o propósito de verificar se os valores gastos nas atividades estão adequados à realidade.

Em relação à terminologia um conceito ressaltado é o despesa orçamentária, que segundo a Lei no 4.320/1964 e Silva (2011), percorre os estágios de fixação, empenho, liquidação e pagamento. Ao estudo se torna relevante o terceiro estágio ou etapa da despesa orçamentária, denominado de liquidação. Este estágio "consiste na verificação do direito adquirido pelo credor tendo por base os títulos e documentos comprobatórios do respectivo crédito" (LEI № 4.320/1964, art. 63). 
Para a apuração de custos este é o estágio da despesa mais importante sendo considerado o ponto de partida para a informação de custos, visto que neste momento é reconhecida como efetivada a despesa, conforme comprovação do serviço prestado ou do material entregue. Nesta etapa é que o sistema de custos passa a ser alimentando com a informação de que efetivamente ocorreu uma operação ou fato, que afetou ou afetará de alguma forma o patrimônio da entidade.

Passa-se a abordar os sistemas de custos e a analisar os principais conceitos aplicados à gestão de custos de empresas que possam servir de base para nortear a construção do sistema de custos do setor público. Cabe ressaltar que não há sistema de custos acabado e que sirva de modelo para toda e qualquer entidade, seja pública ou privada (MAUSS; SOUZA, 2008).

Dessa forma, este trabalho apresenta importantes variáveis que buscam auxiliar a elaboração de um sistema capaz de apurar os custos do serviço público, de acordo com as complexidades e necessidades de cada ente público em particular. Nesse sentido, apresenta-se, primeiramente, o sistema de acumulação de custos. Em seguida, analisa-se o sistema de custeio, que trará o modelo de mensuração de custos a ser utilizado. Por fim, a última variável definida é o método de custeio.

No sistema de acumulação de custos, o controle da produção e a maneira de produzir são os principais aspectos a serem observados. Os sistemas de produção mais relevantes, segundo Machado (2002), e apresentados a seguir, são de produção contínua (processo) e por ordem (encomenda), dos quais derivam outros:

a) por processo - produção de forma contínua em que os custos são acumulados por etapas do processo;

b) por encomenda - para controlar o trabalho de prestadores de serviços que produzam lotes de materiais especiais e componentes.

Para Martins (2010, p. 151), a "produção contínua ou por processo reside na elaboração dos mesmos produtos ou na prestação 
do mesmo serviço de forma continuada por um longo período." Já a produção por encomenda ou por ordem (intermitente) consiste na elaboração de vários produtos de forma descontinuada, ou seja, alocam-se os custos até o término da produção do bem ou serviço.

O sistema de custeio está ligado ao modelo de mensuração dos custos, que dependem das necessidades dos tomadores de decisão. Os modelos mais comumente utilizados são o custo histórico, o custo estimado e o custo-padrão. Segundo Martins (2010), pelo custo histórico os ativos são registrados ou apropriados pelo valor original de entrada. Já o custo estimado o autor entende que é melhor tecnicamente do que trabalhar com custos médios passados, por mudanças na qualidade do produto, introdução de novas tecnologias etc. E o custo padrão pode ser entendido como o custo ideal de produção de um bem ou serviço.

Por fim o método de custeio é um importante aspecto a ser observado para se obter sucesso em um sistema de custos. A escolha da melhor metodologia de custeio deve ser definida de acordo com as necessidades de cada organização, pois permitirá determinar de que maneira os custos serão apropriados aos respectivos objetos de custo. Dentre os métodos mais utilizados estão o custeio por absorção, o custeio variável, o custeio direto, o custeio pleno e o custeio baseado em atividades $(A B C)$, os quais serão abordados na sequência, para os quais podem ser consultados MARTINS (2010), Viceconti e Neves (2013) e Fontoura (2013).

Dessa forma, a partir dos conceitos apresentados sobre sistemas de custos, contabilidade de custos e contabilidade governamental, será possível iniciar a discussão sobre os conceitos que devem nortear um sistema de custos do setor público.

\section{2 - Custos na administração pública}

A administração pública, assim como a contabilidade pública, sofreu transformações nos últimos anos, fazendo com que os mecanismos de controle do orçamento e das finanças fossem aprimorados 
na busca de um novo modelo de gestão. Atualmente, a contabilidade pública está passando por uma fase em que o objetivo é aproximá-la da contabilidade do setor privado, voltando seu foco para o patrimônio. Nesse sentido, busca-se ação planejada e transparente no intuito de prevenir riscos e corrigir distorções que afetem o equilíbrio das contas públicas.

Dessa forma, conforme Mauss e Souza (2008), a gestão pública necessita da contabilidade de custos para lhe oferecer parâmetros e mecanismos que fundamentem o planejamento e a mensuração do resultado das atividades públicas, dando amparo à tomada de decisões, controle gerencial e transparência do serviço público. Contudo, isso não é realidade na administração pública brasileira, ou seja, não há informações de custos na maior parte dos órgãos que, pela legislação, seriam obrigados a apresentá-las. O artigo 99 da Lei no 4.320, de 17 de março de 1964, determina que os serviços públicos manterão contabilidade para determinação dos custos, ingressos e resultados, sem prejuízo da escrituração patrimonial e financeira. $O$ artigo 85 da referida lei também dispõe sobre o assunto:

Os serviços de contabilidade serão organizados de forma a permitirem o acompanhamento da execução orçamentária, o conhecimento da composição patrimonial, a determinação dos custos dos serviços industriais, o levantamento dos balanços gerais, a análise e interpretação dos resultados econômicos e financeiros (LEI № 4.320/1964, art. 85).

O Decreto-lei no 200, de 25 de fevereiro de 1967 também tratou do assunto, determinando no artigo 79 que "a contabilidade deverá apurar os custos dos serviços de forma a evidenciar os resultados da gestão". Outro dispositivo legal que também previu a apuração dos custos foi o Decreto no 93.872, de 23 de dezembro de 1986 determina, no artigo 137, que "a contabilidade deverá apurar o custo dos projetos e atividades, de forma a evidenciar os resultados da gestão." 
Percebe-se que, mesmo com esses dispositivos legais impondo a obrigação de apurar os custos e evidenciar os resultados, pouco se evoluiu. Muito se justifica na falta de instrumentos eficazes para determinar os gastos envolvidos nos processos, programas e atividades do setor público. Também há poucos estudos a respeito do tema, que possam viabilizar a sua implantação de forma racional e eficiente. A escassez de literatura sobre o tema é um dos motivos pelos quais não há a utilização da contabilidade de custos no meio governamental, diferentemente do setor privado.

Dessa forma, com o objetivo de reforçar o que já foi determinado anteriormente, a Lei Complementar no 101/2000, previu, no artigo 50, parágrafo 3ำ que "a Administração Pública manterá sistema de custos que permita a avaliação e o acompanhamento da gestão orçamentária, financeira e patrimonial." Por fim, os últimos dispositivos a tratarem do assunto foram as Resoluções/CFC no 1.129/2008 - Patrimônio e Sistemas Contábeis - e nº 1.366/2011 Sistema de Informação de Custos do Setor Público. A primeira trata dos Sistemas Contábeis, dentre eles o Subsistema de Custos, e deve ser adotado de forma obrigatória para os fatos ocorridos a partir de 1 o de janeiro de 2010. Nela o sistema contábil está estruturado, dentre outros, no subsistema de informações de custos, que tem o objetivo de registrar, processar e evidenciar os custos dos bens e serviços produzidos e oferecidos à sociedade pela entidade púbica. Já esta última norma deve ser aplicada aos exercícios iniciados a partir de $1^{\circ}$ de janeiro de 2012. Ela estabelece conceitos, o objeto, os objetivos e as regras básicas para a mensuração e evidenciação dos custos do setor público e está apresentada como Subsistema de Informação de Custos do Setor Público - SICSP. Além dos aspectos legais a Resolução/CFC nำ1.366/2011 destaca o valor da informação de custos para fins gerenciais, com o objetivo de apoiar programas de controle de custos e qualidade do gasto público. Cabe lembrar que o SICSP é obrigatório em todas as entidades do setor público. 


\section{1- Custos no âmbito municipal}

Assim como nas outras esferas de governo, no âmbito municipal as dificuldades para implantação da contabilidade de custos do setor público é também um enorme desafio, senão ainda maior. Percebese que mesmo com as determinações legais apresentadas anteriormente, principalmente quanto à Resolução/CFC no 1.366/2011, não há detalhes sobre como o sistema de custos deve ser estruturado por parte da administração pública, ainda que esta norma comece a dispor a forma como deve ser apresentado o SICSP.

Alonso (1999) destaca os benefícios da criação do sistema de custos para a administração pública, com foco nos resultados da gestão pública, na redução de custos e no combate ao desperdício, além da identificação de atividades que não agregam valor. Também dá subsídio ao processo orçamentário e à avaliação de planos e melhoria da gestão.

Contudo, não é tarefa fácil apurar custos no setor público. As dificuldades encontradas ocorrem muito pelos diferentes tipos de serviços oferecidos à população e também pela falta de cultura e motivação para apuração de custos no serviço público. Para Alonso (1999) também são entraves a inadequação dos métodos de custeio tradicionais às características do serviço público, além de frequentes mudanças na estrutura organizacional dos órgãos e entidades governamentais. Dessa forma, para se obter sucesso na implantação do sistema de apuração de custos no setor público será necessário, primeiramente, mudar o comportamento dos gestores. Estes devem agir no sentido de buscar aperfeiçoamento de seus quadros técnicos, proporcionando atualização permanente para que seja possível a implantação de algum sistema de apuração de custos capaz de disponibilizar informações úteis aos gestores para a tomada de decisão.

Portanto, mesmo com essas dificuldades, cabe aos municípios buscarem a implantação de um sistema de custos capaz de mensurar e aprimorar a eficiência da gestão pública, muito mais do que apenas cumprir a legislação. 


\section{2 - Sistema de custos do setor público}

A partir das definições apresentadas nos tópicos anteriores, principalmente com o advento da Resolução/CFC № 1.366/2011, é possível introduzir os conceitos que devem nortear um sistema de custos do setor público. Sabe-se que o principal objetivo desse sistema é fornecer aos gestores informações como suporte à tomada de decisão, buscando a eficiência na gestão dos recursos públicos. Conforme a mesma Resolução, o SICSP é apoiado em três elementos, definidos como, sistema de acumulação, sistema de custeio e método de custeio que, conforme Mauss e Souza (2008), são a estrutura para um sistema de custos para a área governamental.

Segundo a Resolução/CFC no 1.366/2011, item 9, o sistema de acumulação "corresponde à forma como os custos são acumulados e apropriados aos bens e serviços e outros objetos de custos e está relacionado ao fluxo físico e real da produção." No setor público a acumulação ocorre por ordem de serviço ou produção e de forma contínua ou processo. Na primeira compreende especificações predeterminadas do serviço ou produto, com tempo de duração limitado. As ordens são mais adequadas para tratar dos custos de investimentos e projetos específicos, como obras. Na segunda, compreende demandas de caráter continuado e a acumulação se dá ao longo do tempo.

Machado e Holanda (2010), afirmam que serviços típicos do setor público como ensino, assistência médica etc., são prestados de forma contínua, requerendo um sistema de acumulação por processo. Significa que os custos desses serviços devem ser acumulados durante um período. Já o sistema por ordem de serviço ou encomenda é utilizado para o custeio de projetos como a construção de uma escola, de uma estrada, de um hospital etc., em que os custos são acumulados até o término do serviço (obra), ou seja, com tempo de duração determinado (MAUSS; SOUZA, 2008). Portanto, presentes os conceitos de projeto e atividade no setor público conclui-se que o custo do projeto deve ser acumulado por ordem e o custo da atividade por processo. 
Já o Sistema de Custeio está associado ao modelo de mensuração e deste modo podem ser custeados os diversos agentes de acumulação de acordo com diferentes unidades de medida, dependendo das necessidades dos tomadores de decisões. Dessa forma, o sistema de custeio está classificado em custo histórico, custo-corrente, custo estimado e custo-padrão (RESOLUÇÃO/CFC № 1.366/2011). Para Machado e Holanda (2010) esse sistema baseia-se nos custos histórico e orçado (custo-padrão).

Conforme Mauss e Souza (2008), esse sistema está associado ao modelo de mensuração das atividades da gestão e visa direcionar as decisões por meio da fixação de padrões quando do planejamento do PPA, da LDO e da LOA. Segundo os autores, o sistema caracteriza-se pela utilização do custo-padrão, que é determinado na fase de produção dos produtos e serviços, isto é, há uma predeterminação dos custos para que ocorra o planejamento para, posteriormente, comparar os custos previstos com os efetivamente incorridos.

Para escolha do método de custeio a ser utilizado no setor público, a decisão deve estar apoiada na disponibilidade de informações e no volume de recursos necessários para obtenção das informações ou dados. As entidades podem adotar mais de uma metodologia de custeamento, dependendo das características dos objetos de custeio. Isso é possível porque no setor público não há limitação legal quanto ao uso de qualquer um dos métodos. Conforme a Resolução/CFC no 1.366/2011, método de custeio refere-se ao método de apropriação de custos e está associado ao processo de identificação e associação do custo ao respectivo objeto custeado. Os principais métodos são: direto, variável, por absorção, pleno e por atividade e, que serão abordados na sequência.

Segundo a Resolução/CFC no 1.366/2011, no Método de Custeio Direto se aloca todos os custos, sejam fixos ou variáveis, diretamente a todos os objetos de custo sem qualquer tipo de rateio ou apropriação. Por esse motivo, Machado e Holanda (2010), são favoráveis a aplicação desse tipo de método ao setor público. Argumentam que por não conter qualquer tipo de rateio, esse método permite analisar o desempenho dos gestores com maior objetividade e sem discus- 
sões sobre custos gerais transferidos. Na visão dos autores, também é importante o fato de que esse método está entranhado no sistema de planejamento, orçamento e contabilização da execução orçamentária. Isso é facilmente demonstrado, pois os projetos e atividades são as categorias utilizadas para a programação das despesas orçamentárias. Dessa forma, são perfeitamente identificáveis as ações de governo sendo possível acumular diretamente as despesas executadas por atividade, projeto, órgão etc. Para Mauss e Souza (2008) o custeio direto é aquele que aloca aos produtos e serviços os custos e despesas que podem ser diretamente relacionados a eles e os demais custos, não diretamente relacionados, são considerados somente na apuração do resultado do período. Percebe-se, portanto, que os custos indiretos que não são definidos diretamente a um produto ou serviço devem ser considerados como custos do período.

No Método de Custeio Variável se apropria aos produtos ou serviços apenas os custos variáveis e considera os custos fixos simplesmente como despesas do período (RESOLUÇÃO/CFC № 1.366/2011). Para Mauss e Souza (2008, p. 50) "o método de custeio variável apropria aos produtos apenas os custos e despesas que variam conforme o seu volume de produção e venda." Não apropria, portanto, os custos e despesas indiretas (geralmente fixos). Dessa forma, esse método oferece uma informação menos completa que o método de custeio direto, pois não agrega em seu custeio os custos e despesas fixas, porém diretas ao objeto de custeio. Ainda segundo os autores, por esse motivo e pelas características dos gastos públicos (predominantemente indiretos), no setor público deve ser utilizado o método de custeio direto, pois possibilita uma visão mais global e objetiva dos custos dos serviços prestados.

Conforme a Resolução/CFC no 1.366/2011, o Método de Custeio por Absorção consiste na apropriação de todos os custos de produção aos respectivos produtos e serviços. Dessa forma, esse método é utilizado com o objetivo de alocar aos produtos ou serviços todos os custos incorridos na produção, sejam diretos ou indiretos. Cabe esclarecer que, segundo Mauss e Souza (2008), só os custos envolvidos diretamente na produção serão alocados aos produtos, sendo os 
demais gastos considerados como despesa e lançados diretamente no resultado do período. Percebe-se, portanto, que por esse método há a necessidade de se utilizar a técnica de rateio para a alocação dos custos indiretos o que gera certa subjetividade ao valor do custo final obtido. Para Maus e Souza (2008), devido à subjetividade característica dos rateios, é difícil utilizar esse método no setor público, visto o alto índice de custos indiretos envolvidos.

Tem-se ainda o Método de Custeio Pleno, que segundo a Resolução/CFC no 1.366/2011, consiste na apropriação de todos os custos de produção e de todas as despesas aos produtos ou serviços.

Por fim, conforme a Resolução/CFC n 1.366/2011, o Método de Custeio por Atividades - ABC considera que todas as atividades desenvolvidas pelas entidades são geradoras de custos e consomem recursos. Dessa forma, procura relacionar as atividades com os objetos de custo por meio de direcionadores, determinando quanto de cada atividade é consumida por cada um deles. "Assim, a contabilidade por atividades tem a capacidade de relacionar os custos de uma atividade a um produto, processo ou serviço, utilizando-se dos direcionadores de custos" (MAUSS; SOUZA, 2008, p. 60). No $A B C$ os custos indiretos são atribuídos a um objeto de custo diretamente relacionado com a atividade que lhe deu origem de uma maneira mais lógica e não por simples rateio. Por direcionador de custo entende-se, conforme Nakagawa (2001), como uma transação que determina a quantidade de trabalho aplicada em determinada atividade e, por consequência, o seu custo. Cabe ressaltar que a implantação do método $A B C$ é complexo porque mensura os custos em todo o processo de desenvolvimento do produto ou serviço. Contudo, o seu uso é justificado em organizações que têm grande volume de custos indiretos envolvidos no processo de produção ou prestação de serviço e oferecem uma variedade grande de produtos ou serviços, o que é o caso do setor público. O ABC relaciona os objetos de custo às atividades desenvolvidas por meio de direcionadores, o que denota um maior grau de acerto na alocação dos custos indiretos. 


\section{3 - Resultados e considerações}

Sabe-se que o Poder Executivo Municipal é constituído por secretarias e que estes órgãos têm de executar os serviços específicos de suas pastas, conforme suas atribuições e especificidades. Como exemplos, apresentam-se dados da Secretaria de Saúde e da Secretaria de Educação do Município de Bento Gonçalves/RS, que se localiza na encosta superior nordeste do Rio Grande do Sul e possui população estimada em mais de 112 mil habitantes (IBGE, 2014) e, conforme sua estrutura administrativa, é constituído por mais de 20 órgãos (BENTO GONÇALVES, 2015).

No ano de 2014, o município executou mais de $\mathrm{R} \$ 313$ milhões em despesas, sendo que desse total, pouco mais de $R \$ 96,3$ milhões foram gastos em saúde e 76 milhões em educação, o que representa, respectivamente, $30,77 \%$ e $24,28 \%$ em relação ao total do orçamento do município. Nesse sentido, cabe ainda considerar os investimentos realizados por algumas secretarias abordando, também, a "terceirização de pessoal".

A tabela 1, a seguir, apresenta um comparativo de despesas executadas entre algumas secretarias municipais.

\section{Tabela 1 - Comparativo de despesas executadas entre Secretarias}

\begin{tabular}{|l|ccc|c|}
\hline & \multicolumn{3}{|c|}{ Despesas Totais Executadas } & \multicolumn{2}{c|}{ Despesas c/ locação - mão de obra } \\
\hline SECRETARIA & $(\mathrm{R} \$)$ milhões & \% sobre total & $(\mathrm{R} \$)$ milhões & \% sobre secretaria \\
\hline Educação & 76,0 & 24,26 & 8,7 & 11,45 \\
Saúde & 96,3 & 30,74 & 24,0 & 24,92 \\
Administração & 54,8 & 17,49 & 0,0 & 0,00 \\
Meio Ambiente & 16,2 & 5,17 & 4,6 & 28,40 \\
Assistência Social & 11,5 & 3,67 & 1,6 & 13,91 \\
Obras & 17,9 & 5,71 & 3,7 & 20,67 \\
Mobilidade Urbana & 8,0 & 2,55 & 0,5 & 6,25 \\
Outras & 32,6 & 10,41 & 0,0 & 0,00 \\
\hline TOTAL ORÇAMENTO & 313,3 & 100,00 & & \\
\hline
\end{tabular}

Fonte: Adaptado de Bento Gonçalves, 2014 
Cabe ressaltar que a despesa executada pela Secretaria de Administração engloba o valor de $R \$ 24,8$ milhões gastos pelo Regime Próprio de Previdência Social - RPPS e, do restante da secretaria ( $R \$$ 30 milhões), mais de $\mathrm{R} \$ 17,5$ milhões foram desembolsados em obrigações patronais.

Com relação à Secretaria de Saúde, a análise dos dados referese à "terceirização" de profissionais médicos. Para isso, o município realizou procedimento licitatório para a contratação do serviço, conforme processo no 2.558/2012, pregão presencial no 46/2012, cujo objeto é a contratação de organização social para gestão de serviços de saúde (BENTO GONÇALVES, 2012).

A tabela 2 apresenta o custo de alguns profissionais médicos referentes ao processo supracitado:

Tabela 2 - Total de colaboradores por função

\begin{tabular}{|l|r|r|r|r|r|}
\hline \multirow{2}{*}{ Função } & \multirow{2}{*}{$\mathbf{n .}$} & \multicolumn{2}{c|}{$\begin{array}{c}\text { Custo Médio Mensal em } \\
\mathbf{2 0 1 2}\end{array}$} & \multicolumn{2}{c|}{$\begin{array}{c}\text { Custo Médio Mensal em } \\
\mathbf{2 0 1 4}\end{array}$} \\
\hline & & $\begin{array}{c}\text { Salário Base } \\
-\mathbf{4 0 h}(\mathbf{R} \$\end{array}$ & $\begin{array}{c}\text { Custo Médio } \\
\text { Mensal (R\$) }\end{array}$ & $\begin{array}{c}\text { Salário Base } \\
\mathbf{- 4 0 h}(\mathbf{R \$ )}\end{array}$ & $\begin{array}{c}\text { Custo Médio } \\
\text { Mensal (R\$) }\end{array}$ \\
\hline Clínico geral (20h) & 15 & $16.701,02$ & $125.257,67$ & $19.350,79$ & $145.130,93$ \\
\hline ESF (20h) & 16 & $18.421,45$ & $147.371,62$ & $21.344,18$ & $170.753,44$ \\
\hline Plantonista (20h) & 30 & $18.421,45$ & $276.321,78$ & $21.344,18$ & $320.162,70$ \\
\hline Especialista (20h) & 23 & $17.153,36$ & $197.263,63$ & $19.874,90$ & $228.561,35$ \\
\hline TOTAIS & & & $746.214,70$ & & $864.608,42$ \\
\hline
\end{tabular}

Fonte: Adaptado de Bento Gonçalves, Pregão Presencial 46/2012.

Destaca-se que do total do orçamento executado na Secretaria de Saúde em 2014, aproximadamente $R \$ 24$ milhões ocorreram em serviços de locação de mão de obra (terceirização de pessoal). Cabe esclarecer que há o cargo de médico no quadro de servidores efetivos do município. Conforme Lei Municipal no 5.802, de 20 de maio de 2014, em dezembro de 2014, o vencimento básico ficou estabelecido, conforme a tabela 3: 
Tabela 3 - Vencimento básico dos cargos de médico (20h)

\begin{tabular}{|c|c|c|c|c|c|c|}
\hline PADRÃO & A & B & C & D & E & F \\
& $\begin{array}{c}0-5 \\
\text { Anos }\end{array}$ & $\begin{array}{c}6-10 \\
\text { Anos }\end{array}$ & $\begin{array}{c}11-15 \\
\text { Anos }\end{array}$ & $\begin{array}{c}16-20 \\
\text { Anos }\end{array}$ & $\begin{array}{c}21-25 \\
\text { Anos }\end{array}$ & $\begin{array}{c}26-30 \\
\text { Anos }\end{array}$ \\
\hline SM6 $(\mathrm{R} \$)$ & $3.018,56$ & $3.320,41$ & $3.471,34$ & $3.622,27$ & $3.773,20$ & $3.924,13$ \\
\hline
\end{tabular}

Fonte: Adaptado de Bento Gonçalves, Lei no 5.802/2014.

Nesse contexto, verificou-se no orçamento do Município que em 2014 foram executados pouco mais de $\mathrm{R} \$ 17$ milhões em remuneração, encargos e direitos dos servidores, sendo que desse valor, $R \$ 15$ milhões foram a título de vencimentos e vantagens fixas. Esses dados destacamse, pois a secretaria gasta mais em terceirização de pessoal do que em pagamento de servidores efetivos. Percebe-se que mais de $24 \%$ do seu orçamento foi executado em locação de mão de obra, valor superior aos 17\% gastos com servidores efetivos (BENTO GONÇALVES, 2015).

Após análise dos dados, verifica-se que a Secretaria de Saúde do Município de Bento Gonçalves está investindo elevada parcela dos seus recursos em contratações de profissionais, pagando valores muito elevados, ainda mais se comparados aos de seu quadro de pessoal.

Ressalta-se que, sobre os vencimentos da tabela 3 há de se considerar os valores com encargos, décimo terceiro salário e férias, diferentemente da tabela 1, visto que os valores contratados já contemplam todas as obrigações trabalhistas e previdenciárias naquela tabela. Contudo, dada a considerável disparidade de valores entre as tabelas, o cálculo torna-se irrelevante ao propósito do presente estudo, tampouco a escolha de sistema e método de custeio.

Outro caso analisado está relacionado ao transporte escolar, que é de responsabilidade da Secretaria de Educação. Verificou-se que em 2014 o Município de Bento Gonçalves investiu quase R\$ 3 miIhões na atividade de manutenção do transporte escolar. Desse total, quase $90 \%$ foi gasto com contratação de empresas para prestação desse serviço. São mais de 45 roteiros para fazer o transporte de alunos, tanto para escolas do município como do estado. 
Cabe ressaltar que a União e o Estado do RS oferecem programas de apoio ao transporte escolar, para despesas de custeio. A União auxilia com o Programa Nacional de Apoio ao Transporte Escolar (PNA$T E)$, que em 2014 transferiu, aproximadamente, $R \$ 92$ mil. O governo estadual auxilia com o Programa Estadual de Apoio ao Transporte Escolar (PEATE), que transferiu em 2014, aproximadamente, $R \$ 400$ mil. Percebe-se que fica a cargo do município a grande parcela de recursos para que o transporte de alunos seja efetuado. Para executar o serviço, o Município é obrigado a recorrer às empresas privadas, pois não dispõe da quantidade suficiente de veículos para a prestação do serviço. Dessa forma, o Município realizou procedimento licitatório para a referida contratação, conforme processo no $158 / 2014$, pregão presencial no 8/2014, cujo objeto é a "contratação de transporte de alunos" (BENTO GONÇALVES, 2014). Na tabela 4, a seguir, apresenta-se o valor contratado de 200 dias letivos, de dois roteiros desse processo, para o transporte de 27 alunos cada:

Tabela 4 - Custo do transporte contratado

\begin{tabular}{|c|c|c|c|c|c|c|}
\hline \multirow[b]{2}{*}{$\begin{array}{l}\text { Item/ } \\
\text { Roteiro }\end{array}$} & \multirow[b]{2}{*}{$\begin{array}{c}\mathrm{Km} \mathrm{p} / \\
\text { dia }\end{array}$} & \multirow[b]{2}{*}{$\begin{array}{l}\text { Alunos } \\
\text { Transp. }\end{array}$} & \multicolumn{4}{|c|}{ Valores $(R \$)$} \\
\hline & & & $\begin{array}{c}\text { Anual } \\
\text { (200 dias) }\end{array}$ & $\begin{array}{l}\text { Mensal } \\
\text { (20 dias) }\end{array}$ & Diário & $\begin{array}{c}\text { Custo p/ } \\
\mathrm{Km}\end{array}$ \\
\hline 42 & 8 & 27 & $47.000,00$ & $4.700,00$ & 235,00 & 29,38 \\
\hline 43 & 8 & 27 & $47.000,00$ & $4.700,00$ & 235,00 & 29,38 \\
\hline
\end{tabular}

Fonte: Adaptado de Bento Gonçalves, 2014. Ata n 4, Pregão Presencial 8/2014.

Destaca-se que o Município também possui veículo próprio, com o qual realiza o transporte de alunos para algumas escolas. Dessa forma, analisaram-se os custos de um veículo com capacidade para transportar 59 alunos, que faz um roteiro com distância e condições de tráfego semelhantes aos dois contratados. O ônibus foi adquirido no início de 2012 ao valor de $\mathrm{R} \$ 212$ mil e para depreciá-lo utiliza-se o método de quotas constantes, estabelecendo-se 15 anos de vida útil, conforme exigência do edital do pregão para contratação do trans- 
porte de alunos. Nas despesas de manutenção estão compreendidas todas as despesas de manutenção geral, como aquisição de peças e mão de obra e, também, despesas com seguro obrigatório, de responsabilidade civil etc. No salário do motorista estão incluídos todos os encargos trabalhistas e previdenciários que são determinados pela legislação. Ressalta-se que essas informações foram obtidas por meio de relatórios e planilhas de controle da Secretaria de Educação, bem como dos diários de bordo no quesito quilômetros rodados no ano.

A tabela 5, a seguir, foi elaborada tomando-se por base o custo histórico e aplicando-se o método de custeio direto.

Tabela 5 - Custo do transporte próprio

\begin{tabular}{|c|c|c|c|c|c|c|}
\hline \multirow[b]{2}{*}{ Descrição item de custo } & \multirow[b]{2}{*}{$\begin{array}{l}\mathrm{Km} \\
\mathrm{p} / \mathrm{dia}\end{array}$} & \multirow[b]{2}{*}{$\begin{array}{l}\text { Alunos } \\
\text { Transp. }\end{array}$} & \multicolumn{4}{|c|}{ Valores (R\$) } \\
\hline & & & $\begin{array}{l}\text { Anual } \\
\text { (200 dias) }\end{array}$ & $\begin{array}{l}\text { Mensal } \\
\text { (20 dias) }\end{array}$ & Diário & $\begin{array}{l}\text { Custo } \\
\mathrm{p} / \\
\mathrm{Km}\end{array}$ \\
\hline Despesas c/ Manutenção & \multirow{5}{*}{73} & \multirow{5}{*}{59} & $5.299,90$ & 529,99 & 26,50 & 0,36 \\
\hline Combustíveis/Lubrificantes & & & $15.541,00$ & $1.541,00$ & 77,71 & 1,06 \\
\hline Salário Motorista & & & $46.469,76$ & $4.646,98$ & 232,35 & 3,18 \\
\hline Depreciação & & & $14.140,40$ & $1.414,04$ & 70,70 & 0,97 \\
\hline Total & & & $81.451,06$ & $8.145,11$ & 407,26 & 5,57 \\
\hline
\end{tabular}

Fonte: Elaborado pelos autores.

As tabelas 4 e 5 mostram que o transporte contratado tem custo por quilômetro rodado cinco vezes superior ao transporte próprio. Contudo, vale ressaltar que não há condições de o Município prestar o serviço na sua totalidade, devido à grande quantidade de roteiros e deslocamentos necessários. Isso demandaria investimento e custo fixo muito elevados.

Entretanto, em alguns roteiros em que se têm o custo por quilômetro rodado muito alto, é cabível a prestação direta do serviço pelo Município. Nesse ponto, destaca-se o Fundo Nacional de Desenvolvimento da Educação (FNDE) que possui um programa denominado 
Caminho da Escola em que os municípios, por meio de convênio, podem adquirir os veículos a um custo de aquisição baixo. Também há linhas de crédito para aquisição de veículos pelo programa que são financiados com recursos do BNDES. Cabe salientar que, com o veículo próprio há a possibilidade de se fazer o transporte dos alunos para outras atividades além das aulas, como competições esportivas, eventos da semana da pátria, datas comemorativas, jogos escolares, tudo a um custo baixo. Ao contrário, se o município não possuísse o veículo, esses transportes deveriam ser contratados.

Esses exemplos servem para ilustrar como a apuração de custos, por mais simples que seja, pode auxiliar o gestor municipal na hora de decidir sobre a contratação de serviços ou sua prestação direta, por exemplo. Nesse sentido, a informação de custos tem papel fundamental nas decisões governamentais. É necessário aumentar o debate sobre mensuração de custos e destacar sua importância para a melhoria do gasto no setor público e a consequente melhora na eficiência da prestação dos serviços públicos.

A apuração de custos no setor público é uma imposição muito antiga para a administração pública brasileira e necessária para os gestores, que podem e devem utilizá-la como subsídio para a tomada de decisão. A implantação de sistema de apuração de custos é um fator importante para o planejamento dos orçamentos previstos pela legislação e é a base para alcançar economicidade, eficiência e eficácia na gestão pública. Percebe-se que a informação de custos é útil, por exemplo, para decidir sobre comprar ou produzir, paralisar ou dar continuidade a determinado serviço, terceirizar ou realizar um serviço por meio próprio etc. Contudo, ainda parece faltar interesse dos gestores e capacidade técnica para os profissionais trabalharem a gestão de custos na administração pública, principalmente na esfera municipal.

Por fim, a implantação de sistema capaz de apurar os custos no serviço público municipal deve ocorrer de forma imediata, não somente porque deve ser cumprida a legislação, mais sim pela importante ferramenta de controle da gestão dos escassos recursos públicos na atualidade, bem como para demonstrar à sociedade de que forma os recursos 
públicos estão sendo utilizados. Sugere-se, em complemento, o desenvolvimento de estudos voltados à busca de instrumentos capazes de medir a eficiência, seja por indicadores quantitativos ou qualitativos, da prestação do serviço público. Pode-se, inclusive, ampliar o tema discutindo a possível precarização do serviço colocado à disposição da população por meio da publicização dos serviços no setor público.

\section{Referências}

ALONSO, Marcos. Custos no serviço público. Revista do Serviço Público, Escola Nacional de Administração Pública, Brasília, DF, v. 1, n. 1, p. 37-63, jan./mar.1999. Disponível em: <http://seer.enap.gov.br/index.php/RSP/issue/viewlssue/63/71>. Acesso em: 13 abr. 2015.

BALEEIRO, Aliomar. Uma introdução à ciência das finanças. 16. ed., rev. e atual. Rio de Janeiro: Forense, 2002.

BENTO GONÇALVES. Estrutura administrativa. 2015. Disponível em: $<$ http://www.bentogoncalves.rs.gov.br/municipio/estrutura-administrativa>. Acesso em: 30 abr. 2015.

Portal da Transparência. Gastos diretos de governo, 2014. Disponível em: <http://e-gov.betha.com.br/transparencia/01010-000/con_ comparativodespesa.faces. Acesso em: 02 mai. 2015.

Portal da Transparência. Gastos diretos por atividade. Disponível em: $<$ http://e-gov.betha.com.br/transparencia/01011-001/con_gastodiretoporprojeto.faces>. Acesso em: 02 mai. 2015.

Pregão presencial no 46/2012. Processo no 2.558/2012. Contratação de organização social. Disponível em: < http://e-gov.betha.com. br/transparencia/01010-000/con_licitacoes.faces?mun=0PTIbW7ye90=>. Acesso em: 02 mai. 2015.

Pregão presencial no 8/2014. Processo no 158/2014. Contratação de transporte de alunos. Disponível em: < http://e-gov.betha.com. br/transparencia/01010-000/con_licitacoes.faces?mun=0PTIbW7ye90=>. Acesso em: 02 mai. 2015.

BRASIL. Constituição (1988). Diário Oficial [da] República Federativa do Brasil, Brasília, DF, 05 out. 1988. 
Decreto no 93.872, de 23 de dezembro de 1986. Dispõe sobre a unificação dos recursos de caixa do Tesouro Nacional, atualiza e consolida a legislação pertinente e dá outras providências. Diário Oficial [da] República Federativa do Brasil, Brasília, DF, 24 dez. 1986.

Decreto-lei no 200, de 25 de fevereiro de 1967. Dispõe sobre a organização da Administração Federal, estabelece diretrizes para a Reforma Administrativa e dá outras providências. Diário Oficial [da] República Federativa do Brasil, Brasília, DF, 27 fev. 1967.

Lei n. 4.320, de 17 de março de 1964. Estatui Normas Gerais de Direito Financeiro para elaboração e controle dos orçamentos e balanços da União, Estados, do Município e do Distrito Federal. Diário Oficial [da] República Federativa do Brasil, Brasília, DF, 23 mar. 1964.

Lei Complementar n. 101, de 04 de maio de 2000. Estabelece normas de finanças públicas voltadas para a responsabilidade na gestão fiscal e dá outras providências. Altera dispositivos da Lei Complementar n. 87, de 13 de setembro de 1996. Diário Oficial [da] República Federativa do Brasil, Brasília, DF, 04 mai. 2000.

Portaria no 42, de 14 de abril de 1999, do Ministério do Orçamento e Gestão. Atualiza a discriminação da despesa por funções de que trata a Lei oㅡ 4.320/1964. Diário Oficial [da] República Federativa do Brasil, Brasília, DF, 15.abr. 1999. Disponível em: <http://www3.tesouro.gov.br/legislacao/download/contabilidade/portaria42.pdfAcesso em: 27 mar. 2015

Resolução CFC № 1.128/2008. Aprova a NBC T 16.1 - Conceituação, Objeto e Campo de Aplicação. Conselho Federal de Contabilidade, Brasília, DF, 21 nov. 2008. Disponível em:< http://www.cfc.org.br/sisweb/ sre/detalhes_sre.aspx?Codigo=2011/001128>. Acesso em: 02 fev. 2015.

Resolução CFC № 1.129/2008. Aprova a NBC T 16.2 - Patrimônio e Sistemas Contábeis. Conselho Federal de Contabilidade, Brasília, DF, 21 nov. 2008. Disponível em:< http://www.cfc.org.br/sisweb/sre/detaIhes_sre.aspx?Codigo=2008/001129>. Acesso em: 02 fev. 2015.

Resolução CFC № 1.366/2011. Aprova a NBC T 16.11 - Sistema de Informação de Custos no Setor Público. Conselho Federal de Contabilidade, Brasília, DF, 25 nov. 2011. Disponível em:< http://www.cfc.org.br/sisweb/sre/ detalhes_sre.aspx?Codigo=2011/001366>. Acesso em: 02 fev. 2015.

FONTOURA, Fernando Batista Bandeira da. Gestão de custos: uma visão integradora e prática dos métodos de custeio. São Paulo: Atlas, 2013. 
GIL, Antonio Carlos. Como elaborar projetos de pesquisa. São Paulo: Atlas, 2002.

IBGE. Estimativas de população. Rio de Janeiro, 2014. Disponível em: $\quad<h t t p: / / w w w . c i d a d e s . i b g e . g o v . b r / x t r a s / p e r f i l . p h p ? l a n g=\& c o d-$ mun $=430210 \&$ search=rio-grande-do-sul $\mid$ bento-goncalves>. Acesso em: 15 abr. 2015.

MACHADO, Nelson. Sistema de informação de custo: diretrizes para a integração ao orçamento público e à contabilidade governamental. 2002. 233f. Tese (Doutorado em Ciências Contábeis) - FEA/USP, São Paulo, 2002.

MACHADO, Nelson; HOLANDA, Vitor Branco de. Diretrizes e modelo conceitual de custos para o setor público a partir da experiência no governo federal do Brasil. Revista de Administração Pública, FGV, Rio de Janeiro, RJ, v. 44, n. 4, p. 791-820, jul./ago. 2010. Disponível em: <http://bibliotecadigital.fgv.br/ojs/index.php/rap/article/view/6949/5516>. Acesso em: 13 abr. 2015.

MARTINS, Eliseu. Contabilidade de Custos. 10. ed. São Paulo: Atlas, 2010. MAUSS, Cézar Volnei; SOUZA, Marcos Antonio de. Gestão de Custos aplicada ao setor público: modelo para mensuração e análise da eficiência e eficácia governamental. São Paulo: Atlas, 2008.

NAKAGAWA, Mazayuki. Custeio baseado em atividades. 2. ed. São Paulo: Atlas, 2001.

ROSA, Maria Berenice. Contabilidade do setor público. São Paulo: Atlas, 2011.

SILVA, Lino Martins da. Contabilidade governamental: um enfoque administrativo da nova contabilidade pública. 5 ed. São Paulo: Atlas, 2011.

VICECONTI, Paulo Eduardo Vilchez; NEVES, Silvério das. Contabilidade de Custos. 11. ed., rev. e atual. São Paulo: Saraiva, 2013.

ZANELLA, Liane Carly Hermes. Metodologia de estudo e pesquisa em administração. Florianópolis, 2009. SEÇÃO III - Resumos dos Trabalhos de Conclusão de Cursos (TCCs) aprovados

Resumos dos 90 TCCs que foram aprovados durante o curso, organizados por ordem alfabética do autor 



\section{SEÇÃO III}

\section{Resumos dos Trabalhos de Conclusão de Cursos (TCCs)}

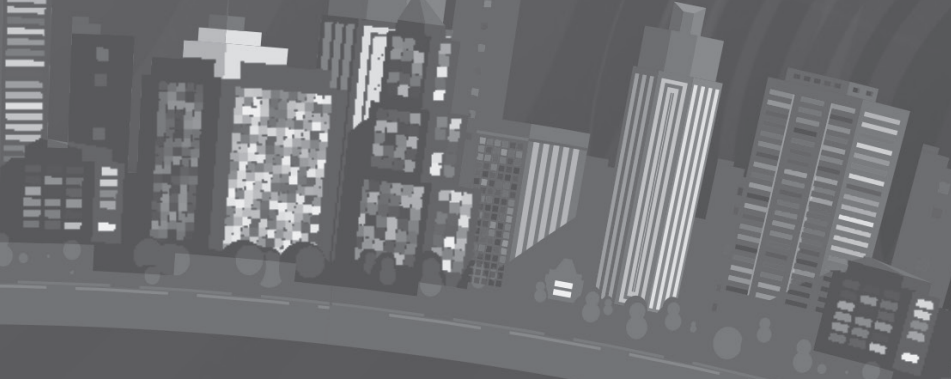



NOME: ADELINA MARIA CASARIL ARBOITE

TíTULO: A IMPORTÂNCIA DA PROFISSIONALIZAÇÃO DA GESTÃO DE PESSOAS NA CÂMARA MUNICIPAL DE GRAVATAÍ

RESUMO: Esse trabalho foi realizado com o intuito de analisar a estrutura de Recursos Humanos da Câmara Municipal de Gravataí, localizada na Região Metropolitana de Porto Alegre, e teve como objetivo principal analisar de que forma a Gestão de Pessoas pode ser um diferencial nas estruturas administrativas da Câmara Municipal de Gravataí. Considerando a importância da profissionalização do servidor público, faz-se necessário a qualificação e a valorização dos mesmos. A metodologia utilizada para a realização desse trabalho foi a pesquisa bibliográfica e um estudo de caso com abordagem quali-quantitativa. A coleta de dados se deu através de um questionário contendo questões abertas e fechadas. A partir dessas informações procurou-se identificar quantos servidores buscaram a profissionalização após o ingresso público e se a Administração oferece algum benefício aos que se qualificaram. Após a aplicação do questionário e análise dos dados obtidos constatou-se que o servidor é quem busca sua profissionalização, por conta própria. Identificou-se que a Administração Pública adota uma política de remuneração através de um Boletim de Merecimento, impresso padronizado, destinado ao registro anual de dados e informações necessárias à avaliação do mérito dos funcionários públicos municipais da Câmara de Vereadores de Gravataí, apenas para a finalidade de promoção horizontal a cada três anos.

Palavras-chave: Gestão de Pessoas. Legislativo municipal. Administração Pública.

\section{NOME: ADRIANA SACHSER \\ TíTULO: ANÁLISE DAS MODALIDADES DE LICITAÇÃO UTILIZADAS NA CÂMARA DE VEREA- DORES DE NOVO HAMBURGO}

RESUMO: O presente trabalho teve como objetivo geral analisar as licitações da Câmara de Vereadores de Novo Hamburgo. O período analisado foi de 2012 a 2014. Para a análise, foram coletados dados junto à Comissão de Licitação, Setor de Compras e Setor Jurídico da Câmara. Após, os dados foram tabulados e comparados, levando em conta os anos a serem estudados e as modalidades de licitação: Concorrência, Tomada de Preços e Pregão, na forma presencial e eletrônica. Por meio de quadros e gráficos, foram analisados o número de licitações por ano e modalidade, o número de licitantes e o percentual de economia obtido. Outro fator que foi analisado foram as políticas públicas e as decisões políticas do Poder Legislativo de Novo Hamburgo, para concluir se elas influenciam nos processos licitatórios. Palavras-chave: Licitação. Legislativo municipal. Políticas Públicas. 
NOME: ALEXANDRE LUIZ KLAUCK

TÍTULO: O PRONAF E O ACESSO DA AGRICULTURA FAMILIAR AO PROGRAMA NO MUNICÍPIO DE PICADA CAFÉ

RESUMO: Este estudo aborda o acesso pelos agricultores familiares de Picada Café ao Programa Nacional de Fortalecimento da Agricultura Familiar (PRONAF) e a forma como a agricultura familiar se estruturou com os incentivos dessa política pública. Assim, serão apresentados os dados do PRONAF em Picada Café entre os anos de 2009 e 2014. A metodologia usada constitui-se de um levantamento de dados bibliográficos e aplicação de entrevistas semiestruturadas à agricultores familiares de Picada Café e ao extensionista rural da empresa de assistência técnica no município, com enfoque na relação entre a agricultura familiar e o PRONAF no município. Dados apresentados em tabelas caracterizam a agricultura familiar e o PRONAF, além de caracterizar a situação da agricultura familiar no município de Picada Café. Ademais, as descrições apresentadas através da análise dos resultados foram satisfatórias, pois o PRONAF conseguiu estruturar, fortalecer e manter muitas famílias na atividade agrícola.

Palavras-chave: Política pública. Programa Nacional de Fortalecimento da Agricultura Familiar. Agricultura familiar.

NOME: ALEXANDRE PAES DE SOUZA

TíTULO: ANÁLISE TRIBUTÁRIA DO MUNICÍPIO DE SANTO ANTÔNIO DA PATRULHA-RS: DE 2005 A 2014

RESUMO: Este trabalho teve como objetivo analisar a matriz tributária do município de Santo Antônio da Patrulha (RS), com a finalidade de apresentar alternativas que possibilitem incrementar a arrecadação municipal por meio dos tributos próprios. Para alcançar esse objetivo, analisou-se a distribuição das competências tributárias aos municípios, bem como a sua inserção no pacto federativo brasileiro, a partir da Constituição Federal de 1988. Analisou-se, após, o comportamento da arrecadação tributária do município no período de 2005 a 2014, identificando potencialidades que possibilitem a ampliação da receita própria e, por consequência, aumentando o grau de autonomia do município. Observa-se que a arrecadação tributária cresceu $122,7 \%$ no período estudado, acompanhando o crescimento da arrecadação total do município que, no mesmo período, cresceu 122,2\%. Ressalta-se que o crescimento do IPTU não acompanhou o crescimento das demais receitas tributárias, crescendo apenas 67,2\%. Diante disso, apresenta-se como alternativa, para a ampliação da arrecadação desse tributo a adoção de medidas como a revisão da planta de valores, a revisão do cadastro imobiliário e a alteração na legislação que concede isenção a novos loteamentos. Foram indicadas, também, medidas para ampliação da arrecadação do ISS, ITBI, Taxa de Coleta de Lixo e Contribuição de Melhoria.

Palavras-chave: Tributos municipais. Orçamento público. Reforma tributária. Administração pública. 


\section{NOME: ANA MARIA VENTURA NETTO DAL BEN \\ TÍTULO: FERRAMENTAS DE PARTICIPAÇÃO ELETRÔNICA PARA PORTO ALEGRE}

RESUMO: O presente estudo aborda o tema da participação cidadã pela Internet (ou e participação) e tem como objetivo principal contribuir para a ampliação das iniciativas de participação eletrônica no município de Porto Alegre, procurando responder à pergunta "Que outras práticas destinadas à participação cidadã pela Internet a Prefeitura e a Câmara Municipal de Porto Alegre poderiam adotar?" Na tentativa de encontrar respostas para essa pergunta, o primeiro passo consistiu em captar o pensamento dos principais autores sobre o tema e sobre as dificuldades para a implantação de projetos dessa natureza. Na sequência, foi realizado um levantamento, em sites do Brasil e de outros países, em busca de iniciativas que representam exemplos de boas práticas de e-participação. Posteriormente, foram analisados qualitativamente os mecanismos voltados à participação civil pela Internet, disponibilizados pela Prefeitura e pela Câmara Municipal de Porto Alegre (em particular, aqueles vigentes no ano de 2014). Por fim, casos encontrados no levantamento realizado no segundo passo foram indicados como referências para novas iniciativas no campo da participação eletrônica que possam vir a ser empreendidas pela Prefeitura e pela Câmara Municipal de Porto Alegre. Ficou, no entanto, o pedido de atenção aos riscos que podem envolver um projeto dessa natureza, os quais foram citados em conjunto com as medidas destinadas a evitá-los ou minorá-los.

Palavras-chave: Democracia digital. Participação eletrônica. Participação cidadã. Internet.

\section{$\star * \star$}

NOME: ANDERSON MARTINS DA SILVEIRA

TíTULO: A JUDICIALIZAÇÃO DA CONCESSÃO DE MEDICAMENTOS: ESTUDO DA SITUAÇÃO DE PORTO ALEGRE

RESUMO: No município de Porto Alegre, a judicialização de pedidos de concessão de medicamentos, ou seja, o fornecimento de medicação através da via judicial tem se desvelado como questão preocupante, pois, ao redirecionar recursos públicos para o atendimento às demandas judiciais, pode-se deixar de atender outros setores da saúde. Pelo contexto apresentado, emergiu a vontade de saber de que maneira a identificação das causas das demandas judiciais de concessão de medicamentos, no município de Porto Alegre, pode tornar mais eficaz a orientação à população? O presente estudo, além de apresentar conceitos doutrinários, definições legais, levanta as demandas judiciais de concessão de medicamentos no município de Porto Alegre, entre 2012 e 2014, bem como tipifica as causas dessas demandas. Além disso, elabora documento orientador da população em relação à concessão de medicamentos e levanta o impacto financeiro das demandas judiciais de concessão de medicamentos no município de Porto Alegre. Portanto, o serviço ofertado pelo município de Porto Alegre, no que diz respeito à concessão de medicamentos é satisfatório. Contudo, cabe ao ente municipal trabalhar para melhorar e rumar ao índice zero.

Palavras-chave: Medicamentos. Ciclo da assistência farmacêutica. Judicialização da saúde. 
NOME: ANDRIO AGUIAR

TÍTULO: POLÍTICA DE TRANSPORTE ESCOLAR RURAL NO MUNICÍPIO DE CANGUÇU-RS: DESAFIO REPASSE X REALIDADE

RESUMO: De acordo com a Constituição Federal, cabe a cada ente federado garantir o transporte dos alunos da sua rede de ensino. No entanto, recai a muitos municípios brasileiros a responsabilidade de suprir a insuficiência de recursos entre o valor licitado e o valor repassado pelo ente federado e estadual. Dentro deste contexto o presente trabalho tem como objetivo analisar as políticas governamentais e os valores repassados pela União e pelo estado do Rio Grande do Sul para o município de Canguçu, através do convênio assinado via Federação das Associações de Municípios do Rio Grande do Sul (FAMURS) para realizar o transporte dos alunos da zona rural do município. Teoricamente as políticas públicas educacionais, num Estado democrático de direito, terão por objetivo a efetivação da garantia do direito à educação, esse direito poderá ser assegurado por políticas de acesso, de permanência ou de qualidade, ou de todos esses elementos congregados. A política do transporte escolar rural, objeto de estudo deste trabalho, enfoca o acesso, e, garantindo o acesso, é uma das formas de garantir o direito à educação. Com o estudo, percebeu-se que a realidade do transporte escolar nos municípios é bastante difícil, devido à defasagem do valor repassado pela união e pelo estado. O município de Canguçu tem um alto índice de alunos transportados na zona rural e apresenta um expressivo esforço financeiro, comprometendo parte de seus recursos para garantir o acesso à educação.

Palavras-chave: Transporte escolar. Políticas de educação. Administração pública. Políticas públicas.

NOME: ANTONIO JOSÉ HARTMANN

TíTULO: A GESTÃO MUNICIPAL FRENTE AO CUMPRIMENTO DA LEI COMPLEMENTAR 14.376/2013 EM PRÉDIOS PÚBLICOS DO MUNICÍPIO DE GRAVATAÍ - RS.

RESUMO: Este trabalho focaliza a legislação de Prevenção e Combate a Incêndios do estado do Rio Grande do Sul, Lei Complementar 14.376/2013, buscando verificar o seu cumprimento nos prédios e instalações utilizados pela Prefeitura Municipal de Gravataí. A pesquisa foi desenvolvida com exploração bibliográfica conceitual, legal e histórica, aprofundando o conhecimento sobre os temas envolvidos. Em exploração documental junto de Secretarias municipais buscou dados para caracterizar o município, aspectos estruturais da Prefeitura, os prédios públicos e dados do cumprimento da legislação específica nestes. Em pesquisa em campo levantou a situação de cinco prédios, como amostras para verificar o atendimento de itens da legislação escolhida em prédios utilizados pela Prefeitura. Levantados os dados documentais e feita pesquisa em campo, foi realizada avaliação a luz da legislação. Foi desenvolvida também pesquisa por meio de entrevistas com Gestores e outros Servidores do Município, sobre seu conhecimento desta lei, sobre a suas opiniões quanto a importância do seu cumprimento na Prefeitura e sobre as possíveis limitações para os Gestores Municipais ao seu cumprimento. As conclusões foram que: apesar da sua importância e obrigatorieda- 
de a Lei Complementar 14.376/2013 não é atendida nos prédios e instalações da Prefeitura, sendo que na atual gestão, em 2014, foi iniciado amplo processo para regularização de todos os prédios usados pela Prefeitura e, das opiniões das entrevistas, todos os entrevistados tem algum conhecimento desta legislação, todos consideram muito importante sua aplicação nos prédios da Prefeitura e indicaram como possíveis limitações para sua aplicação pelos Gestores Públicos no município: recursos financeiros escassos, falta de interesse político, deficiências de estrutura material e humana, desconhecimento da lei pelos Gestores, despreparo dos Gestores, falhas de gestão, omissão ou deficiência na fiscalização, entre outros. Palavras-chave: Administração Pública. Lei 14.376/13. Prevenção de Incêndio.

NOME: ARIANE CRISTINA BERTI

TÍTULO: O CONTROLE INTERNO DE NOVA PETRÓPOLIS: COMO SUAS RECOMENDAÇÕES SÃO UTILIZADAS PELA ADMINISTRAÇÃO MUNICIPAL

RESUMO: A complexidade da Administração Pública exige cada vez mais o controle de seu aparato; este é exercido também pelas Unidades de Controle Interno que são estruturas idealizadas pela Constituição Federal de 1988 e com implementação obrigatória a partir da Lei de Responsabilidade Fiscal de 2000. Esta pesquisa buscou responder de que maneira o gestor público utiliza as recomendações do Controle Interno Municipal, utilizando-se do município de Nova Petrópolis (RS) para a realização de um estudo de caso de cunho exploratório. A metodologia foi a pesquisa qualitativa e como procedimento técnico de coleta de dados a análise documental da legislação existente, dos relatórios do Tribunal de Contas do Estado do Rio Grande do Sul e dos documentos elaborados pelo próprio Controle Interno. Justificou-se a pesquisa pelas dúvidas com relação à efetividade do trabalho do Controle Interno, para o preenchimento de lacunas existentes sobre o assunto e pelo seu cunho social, visto ser o gestor o "gerente" da coisa pública e, portanto, responsável pelo adequado gerenciamento e aplicação das boas práticas dentro da Administração. Conclusivamente foi possível apurar que uma pequena parte das orientações do Controle Interno foram utilizadas pelo gestor, no entanto, seria imprudente afirmar que ele não as utiliza, pois, a aplicabilidade de boa parte delas não pode ser verificada, por não corresponder àquelas que diziam respeito diretamente aos apontes do Tribunal de Contas destacados pela pesquisa. Este também foi o motivo que prejudicou a análise da efetividade do trabalho do Controle Interno. Palavras-chave: Auditoria. Tribunal de Contas. Orçamento público. Administração pública. 


\section{NOME: BIANCA PINTO PEREIRA \\ TíTULO: ANÁLISE DO SISTEMA DE SAUUDE PÚBLICA NO MUNICÍPIO DE CAMBARÁ DO SUL - RS}

RESUMO: A preocupação com a saúde da população e de que forma o poder público soluciona os problemas tem sido o objetivo maior. O município, através de sua estrutura organizacional, tem o dever de prestar um serviço de qualidade ao se tratar da saúde pública, assim como praticar ações de prevenção como medida protetiva em diferentes áreas (educação, assistência social e saúde). O objetivo do presente trabalho é descrever o sistema de saúde de Cambará do Sul (RS) e sua contribuição às políticas preventivas de saúde. No referencial teórico, discorre-se sobre as políticas públicas e a eficiência do serviço público. O método utilizado para o desenvolvimento deste estudo é uma pesquisa descritiva, no que diz respeito aos objetivos a serem alcançados, com análise dos conteúdos, permitindo o enfoque intuitivo no exame dos dados coletados. Conclui-se, conforme a análise dos dados obtidos na secretaria de saúde do município, que ainda persistem problemas ligados à prevenção, doenças transmissíveis e pouco investimento do poder público em relação a políticas públicas.

Palavras-chave: Sistema Único de Saúde. Políticas de saúde. Administração pública.

$$
\star \star \star
$$

NOME: CARINE LINDORFER PANKE

TíTULO: DESAFIOS E PERSPECTIVAS DO ATENDIMENTO AO PÚBLICO NA CÂMARA MUNICIPAL DE IJUÍ

RESUMO: Alvo de muitas reclamações por parte dos cidadãos, o serviço de atendimento ao público necessita de melhorias urgentes. Tal tarefa depende de vários aspectos como a definição do termo mais adequado para identificar a pessoa atendida num órgão público e a clareza do que é um bom atendimento e um bom atendente. Além disso, alguns fatores como o uso de tecnologias e a participação popular também auxiliam na qualificação do serviço de atendimento. Sem o envolvimento das pessoas na gestão da coisa pública fica difícil atender as reais necessidades dos cidadãos. Esta pesquisa apresentará algumas especificidades do atendimento ao público no Poder Legislativo Municipal, realizando um estudo de caso na Câmara Municipal de ljuí. A reflexão ficará em torno das dificuldades percebidas por quem realiza e por quem recebe atendimento neste órgão, baseada em entrevistas e na observação participante da pesquisadora. Tem como propósito apresentar sugestões e alternativas para alcançar a excelência do atendimento ao público, serviço que ganha cada vez mais importância devido à abertura que a democracia proporciona, além do aumento da exigência da sociedade por maior qualidade nesta área da administração pública.

Palavras-chave: cidadão, atendimento de qualidade. Poder Legislativo Municipal. Dificuldades no atendimento ao público. 
NOME: CARLA IONE QUATRIN

TÍTULO: ANALISAR A GESTÃO DOS RECURSOS DESTINADOS AO ATENDIMENTO DE IDOSOS EM SANTA MARIA/RS

RESUMO: A institucionalização vem se tornando uma das formas encontradas pelas famílias e pelo poder público para evitar o abandono de idosos em setores públicos como hospitais. Porém é necessário saber de que forma os recursos destinados a estas instituições são obtidos, visto que, políticas públicas para os idosos existem e inclusive, exigem o repasse de verbas públicas para a manutenção da saúde e cuidados dos idosos. Este estudo teve como objetivo analisar a gestão dos recursos de uma instituição de caráter social que mantém idosos institucionalizados na cidade Santa Maria (RS). Para isso, buscou-se verificar quais são as políticas de gestão dos recursos da Internação de Longa Permanência para Idosos (ILPI); descrever como ocorre a gestão dos recursos da ILPI, problematizar a destinação de recursos financeiros para garantir os direitos básicos para a população idosa em Santa Maria (RS). Percebeu-se ao longo do estudo realizado na Instituição a angustia de angariar recursos e manter a mesma e assim, garantir um atendimento digno e de qualidade as idosas abrigadas nesse espaço. No entanto, fica a certeza de que se precisa muito avançar para aplicar as políticas públicas de maneira mais eficiente nos serviços que prestam atendimento a esse segmento da população. Falta ainda nos estruturarmos melhor a fim de atender essa demanda populacional em elevado crescimento.

Palavras-chave: Envelhecimento. Assistência social. Políticas de saúde. Internação de longa permanência para idosos.

\section{$\star \star \star$}

NOME: CAROLINA MARIA QUADROS

TÍTULO: FÓRUM DE POLITICAS SOCIAIS DE ESTEIO: AVANÇOS E DESAFIOS PARA INSERÇÃO DE FAMÍLIAS EM SITUAÇÃO DE EXTREMA POBREZA EM POLÍTICAS PÚBLICAS

RESUMO: A consulta aos indicadores sociais de Esteio (RS) demonstra que o município se destaca na Grande Porto Alegre pelos altos índices de qualidade de vida. Entretanto, dados do Ministério do Desenvolvimento Social e Combate à Fome (MDS) evidenciam que uma parcela da população se encontra em situação de extrema pobreza. Esta contradição instigou a realização da pesquisa com famílias beneficiárias do "Programa RS Mais Igual" na Região 5 do Orçamento Participativo (OP). Com abordagem qualitativa, teve o objetivo de analisar os avanços e desafios produzidos pela atuação do FPS de Esteio mediante a investigação das ações desenvolvidas nos anos de 2013 e 2014, com destaque para o mapeamento e cruzamento das políticas públicas, a observação participante, entrevistas, consulta a documentos secundários e, especialmente, à pesquisa realizada pelo Instituto Fidedigna (IF). Os resultados da análise demonstraram que a intersetorialidade tem qualificado a atuação dos agentes públicos para a ampliação da oferta e acesso aos serviços públicos, todavia não foi possível verificar se houve mudança na situação das famílias entrevistadas pelo IF pelo fato de não haver dados compilados a partir das ações realizadas em 2013. Além disso, a institucionalização do FPS, a compilação de dados por Região do OP e a atualização do Cadúnico são os desafios que se apresentam ao FPS. Por fim, são sugeridas ações para a institucionalizar e qualificar a atuação do Fórum de Políticas Sociais de Esteio. Palavras-chave: Programa RS Mais Igual. Orçamento Participativo. Orçamento público. Administração pública. Políticas sociais. 
NOME: CAROLINE TELES WITT

TÍTULO: A JUDICIALIZAÇÃO DA SAÚDE EM NOVA PETRÓPOLIS/RS: ANÁLISE DOS CUSTOS ADVINDOS DA DISPENSAÇÃO DE MEDICAMENTOS ONCOLÓGICOS

RESUMO: O fenômeno da judicialização da saúde atingiu seu ápice nos últimos anos e tem se revelado como uma questão preocupante, tanto para os gestores públicos, quanto para os cidadãos. O direito à saúde foi reconhecido pela Constituição Federal como fundamental ao homem, por lhe assegurar a dignidade e o próprio direito à vida. Ocorre que, diante da omissão do Poder Público em tutelar esse direito fundamental, o cidadão acaba por socorre-se da intervenção do Poder Judiciário. Assim sendo, são proferidas inúmeras decisões judiciais em desfavor dos entes públicos, em inobservância à delimitação das competências instituídas por lei. Partindo desta premissa, buscou-se conhecer se existem e quais são as políticas públicas que deixaram de ser efetivadas pelo Município de Nova Petrópolis em razão do desvio de verbas públicas, ocasionado pelo cumprimento de decisões judiciais que obrigam o Município a fornecer tratamentos e medicamentos oncológicos. A presente pesquisa apresenta os conceitos doutrinários e teóricos relativos ao desenvolvimento desta problemática, além de identificar as demandas ajuizadas em face do Município nos anos de 2013 e 2014 e o impacto financeiro que estas representaram para a Secretaria Municipal da Saúde, na tentativa de auxiliar, mesmo que de forma ínfima, os gestores públicos a planejarem suas ações sem desconsiderar o fenômeno da judicialização.

Palavras-chave: Medicamentos. Judicialização da saúde. Políticas de saúde. Administração pública.

NOME: CHARLENE TERESINHA SANDER DUBAJ

TÍTULO: O INTERESSE PÚBLICO COMO BALIZADOR PARA A APROVAÇÃO DE LEIS EM CARÁTER EMERGENCIAL NA CÂMARA DE VEREADORES DE TAPES/RS

RESUMO: O presente trabalho analisa o uso do interesse público como balizador para aprovação de leis em caráter emergencial. Partindo do princípio de que interesse público é o interesse social, do povo, e não a vontade do poder público, seu designo só poderia ser utilizado com a finalidade de atender a um real desejo ou necessidade dos cidadãos, caracterizando o interesse público primário; sendo que a vontade do poder público, enquanto pessoa jurídica, só pode ser atendida se também for da vontade do povo, caracterizando o interesse público secundário. Assim, caso o poder público utilize o designo de interesse público de outra forma, estará incorrendo em abuso de poder. Tendo em vista este contexto, buscou-se analisar o uso do interesse público para a aprovação de leis em caráter emergencial no município de Tapes (RS). Para tanto, realizou-se uma revisão teórica sobre o assunto e, após, uma análise de conteúdo nas leis aprovadas. Determinou-se como amostra as leis publicadas no município de Tapes entre os anos 2010 e 2014. Ao todo, foram publicadas 265 normas jurídicas, das quais, 35 se tratavam de leis visando a contratação temporária emergencial de excepcional interesse público. Dentre estas 35 leis, verificou-se que 67 estavam em consonância com os objetivos do interesse público, enquanto as outras 89 não puderam ser assim definidas. Considerando as leis analisadas e os concursos realizados no período (juntamente com suas aprovações e nomeações), concluiu-se que a maioria das contratações temporárias é justificável devido às características de suas vagas e/ou ao fato de não haver profissionais concursados para serem nomeados, mas nem sempre são justificáveis do ponto de visto do interesse público.

Palavras-chave: Direito público. Administração pública. Legislativo municipal. 


\section{NOME: CÍNTIA MARTTA MORAES \\ TíTULO: A GESTÃO NO ACOMPANHAMENTO DE OBRAS PÚBLICAS EM SAPIRANGA/RS}

RESUMO: A gestão no acompanhamento de obras é uma ferramenta de controle eficaz para obras de cunho público. Este trabalho apresenta um estudo sobre a presença da gestão no acompanhamento de obras públicas no município de Sapiranga (RS). O tema verifica os métodos de gestão, se há uma correta compreensão e uso da legislação relacionada à licitação e fiscalização e a compatibilização do processo de acompanhamento de obras. O projeto básico, a licitação e a fiscalização são etapas essenciais para o processo de execução de obras públicas e são abordados mais profundamente para o melhor entendimento de todo o estudo. Para tanto, é analisado o estudo de caso, ilustrando a realidade vivida em Sapiranga, com a construção de Unidade de Saúde. O estudo de caso possibilita a compreensão do comportamento dos agentes e servidores perante divergências entre projeto e fiscalização e suas consequências, que são os aditivos e supressões. Com o desenvolvimento deste trabalho, é possível verificar o porquê das incompatibilidades entre projeto, memorial descritivo e orçamento antes de encaminhar ao processo licitatório. Com a solução da compatibilização, acredita-se que a fiscalização não terá problemas na obra e não trará prejuízos ao Município. Com a incompatibilidade, percebe-se a existência de transtornos burocráticos internos que atrasam os cronogramas das obras e acarretam em prejuízos financeiros.

Palavras-chave: Administração pública. Orçamento público. Lei das licitações. Infraestrutura.

$$
\star \star \star
$$

NOME: CLAIR TEREZINHA BÁO

TíTULO: A APLICAÇÃO DE RECURSOS ORÇAMENTÁRIOS ATRAVÉS DE TRANSFERÊNCIAS VOLUNTÁRIAS E A IMPLANTAÇÃO DO SISTEMA DE CONVÊNIOS - SICONV: ESTUDO DE CASO DO MUNICÍPIO DE IJUÍ

RESUMO: O estudo sobre a aplicação de recursos orçamentários através de transferências voluntárias e a implantação do sistema de convênios (SICONV) é desenvolvido com base no município de ljuí - Poder Executivo. O objetivo é identificar as práticas e os controles realizados na execução de convênios e contratos de repasse, tendo como base os aspectos legais inerentes à aplicação de recursos públicos, e, a partir desse conhecimento, analisar e propor melhorias dessas práticas e rotinas de gestão, para otimizar os resultados com maior eficiência e eficácia. O desenvolvimento do trabalho aborda incialmente o histórico do Município e suas principais potencialidades, apresenta o quadro teórico que embasa o tema de estudos com as teorias e as normas legais, os procedimentos metodológicos, a descrição das práticas/controles adotados pelo município na execução de convênios, e uma análise da forma como ocorrem as ações. Na conclusão, a constatação da importância desses recursos para implementar melhorias na infraestrutura básica municipal, considerando a escassez de recursos próprios, a complexidade e o tamanho do custo operacional para as três esferas de governo, na operacionalização de transferências voluntárias, e, diante da realidade que persiste, a sugestão, para reorganizar a estrutura organizacional do poder executivo, centralizar a coordenação e uma equipe multidisciplinar que proporcione meIhor suporte técnico e acompanhamento na execução de convênios. Com essa nova dinâmica organizacional, acredita-se que os resultados sejam proporcionalmente mais eficientes e eficazes para os cidadãos, a sociedade e os poderes públicos, prevenindo retrabalhos, economia de tempo e custos, inadimplência, tomada de contas especial e a devolução de recursos.

Palavras-chave: Orçamento público. Auditoria. Administração pública. Executivo municipal. 
NOME: CLÁUCIA PICCOLI FAGANELLO

TíTULO: ANÁLISE DA IMPLEMENTAÇÃO DO SISPARCI NO ESTADO DO RIO GRANDE DO SUL

RESUMO: No contexto das democracias atuais, discutir participação, controle social e transparência fazem parte da relação entre o cidadão e o Estado. Assim, no estado do Rio Grande do Sul (RS) diversos mecanismos esparsos foram agrupados de forma sistemática e inovadora, constituindo o Sistema Estadual de Participação Popular e Cidadã (SISPARCI). O presente trabalho se propõe a realizar a análise do SISPARCI, que visa ampliar as vias de participação popular e cidadã. Como objetivos específicos, pretende-se analisar e caracterizar o SISPARCI, assim como, verificar as mudanças de paradigmas no que se refere à participação na Administração Pública do Estado. A metodologia escolhida é o estudo de caso. Este trabalho se justifica devido à importância do instituto da participação nas democracias atuais, sendo, inclusive, uma das formas de verificar a qualidade das mesmas. A escolha do SISPARCI ocorre pelo seu caráter diferente frente às experiências anteriores e pela ausência de estudos sobre o sistema. Outro fator relevante na escolha do tema foi o fato de que o SISPARCI ganhou o 1 ? lugar no prêmio "Nações Unidas ao Serviço Público".

Palavras-chave: Administração pública. Participação social. Cidadania. Sistema de informação.

NOME: CLAUDETE DE SOUZA

TÍTULO: OS OBSERVATÓRIOS DE SEGURANÇA PÚBLICA MUNICIPAIS COMO FERRAMENTA DE GESTÃO - ESTUDO DE CASO DO MUNICÍPIO DE CANOAS-RS.

RESUMO: A crescente onda de violência nos municípios brasileiros, em especial nos centros urbanos, exige melhor resposta do aparato estatal, que tem o dever de prevenir e reprimir a violência urbana e exercer o controle da ordem social conforme o conteúdo da Carta Constitucional. Neste contexto, o Governo Federal, inaugura uma nova fase na história da segurança pública no Brasil, focado na implantação do Sistema Único de Segurança Pública (SUSP), e com a criação do Programa Nacional de Segurança Pública com Cidadania (PRONASCI). Neste aspecto Azevedo (2007) aponta a necessidade de empenho dos governos municipais e da sociedade civil em programar políticas públicas locais de prevenção e controle da violência. Sendo assim, este estudo teve como objetivo verificar até que ponto o Observatório de Segurança Pública (OSP) fornece suporte analítico para a tomada de decisões nas ações de segurança pública no município de Canoas (RS). Como resultado, a pesquisa demonstrou, por meio de um estudo de caso, com abordagem qualitativa, que o Observatório é considerado uma ferramenta de gestão e que fortalece a capacidade do município em planejar políticas públicas de segurança. Este estudo é importante para sensibilizar os gestores públicos municipais, para que se sintam comprometidos com as questões de segurança pública. Palavras-chave: Segurança pública. Administração pública. Observatório de Segurança Pública. Programa Nacional de Segurança Pública com Cidadania. 
NOME: CRISTIAN ROSA MURARO

TÍTULO: INOVAR NA CAPTAÇÃO DE FORNECEDORES PARA O MUNICÍPIO DE CANOAS

RESUMO: A pesquisa apresentada tem como objetivo principal a captação de fornecedores para o município de Canoas (RS). Com isso, a análise tem início na identificação dos procedimentos e processos para cadastro e captação de fornecedores para o município. Na sequência, realizou-se a análise junto ao setor de cadastro de fornecedores da Prefeitura Municipal de Canoas, através de pesquisa qualitativa, seguindo o caráter exploratório e descritivo com análise documental, observação e entrevista aberta com trinta empresas fornecedoras de Canoas no ano de 2015 e também foi realizada entrevista por pauta para coleta de respostas de perguntas obtidas com cinco prefeituras no ano de 2015 da região metropolitana de Porto Alegre. Também foi apresentada estrutura organizacional, as principais funções realizadas pela administração pública, o orçamento público e as metas de governo. Ao final, conclui-se que a insuficiência de fornecedores pode ser superada com mudanças no setor de Cadastro com autorização da gestão e sugerem-se melhorias, como por exemplo, quando esses atualizarem seus alvarás devem realizá-lo através de um cadastro completo visando maio facilidade na captação dos mesmos, ampliando, desta forma, a carteira de fornecedores que é o grande objetivo.

Palavras-chave: Administração pública. Orçamento público. Lei das licitações.

NOME: CRISTIANA ELIZABETI SOHNE

TíTULO: O PERFIL DE BENEFICIÁRIOS E A GESTÃO DE UM REGIME PRÓPRIO DE PREVIDÊNCIA SOCIAL: UMA ANÁLISE DO MUNICÍPIO DE IGREJINHA

RESUMO: O Instituto de Previdência dos Servidores Públicos Municipais de Igrejinha (IPREMI) foi instituído pela Lei no 2.776 , de 1999, que dispõe sobre a seguridade dos servidores. A vivência e o estudo de assuntos relacionados à previdência motivaram o interesse pelo aprofundamento de um tema que se tem discutido muito que é a elevação da expectativa de vida da população brasileira. O objetivo deste trabalho é caracterizar como as mudanças estruturais da população brasileira, decorrentes do processo de transição demográfica influenciam/influenciarão o IPREMI a curto/longo prazo. Para tanto, é desenvolvida a pesquisa descritiva, através de uma abordagem qualitativa e como fonte de informações utilizou-se a pesquisa bibliográfica e documental. Este trabalho apresenta suas referências teóricas abordando três aspectos: sendo o primeiro, a conceituação e história dos regimes próprios de previdência no Brasil e do regime próprio de Igrejinha, a contextualização do déficit atuarial do IPREMI e o bônus demográfico brasileiro. O segundo aspecto apresenta os dados usados para a análise do perfil do beneficiário do IPREMI, bem como a análise feita, e, por último, os resultados da pesquisa, concluindo que o processo de transição demográfica influencia na gestão do IPREMI.

Palavras-chave: Administração pública. Gestão de pessoas. Regime de previdência. Transição demográfica. Bônus demográfico. 


\section{NOME: CRISTIANE CARDOZO PADILHA \\ TíTULO: MOTIVAÇÃO NO SERVIÇO PÚBLICO MUNICIPAL: ESTUDO DE CASO NA SECRETA- RIA DE GESTÃO ADMINISTRATIVA E FINANCEIRA}

RESUMO: O presente estudo teve como objetivo analisar a motivação dos servidores da Secretaria de Gestão Administrativa e Financeira da Prefeitura de Pelotas (RS). Para atender aos objetivos específicos, foi realizado um levantamento de dados, através de questionário, respondido por setenta e seis colaboradores da referida Secretaria, visando identificar os fatores motivacionais do ambiente de trabalho, bem como os fatores que influenciam a motivação, os que mais geram satisfação e os que previnem a insatisfação, entre os servidores públicos municipais. A análise dos dados levantados constatou que as variáveis pesquisadas apresentam diferentes percentuais em relação aos fatores de motivação, assim como as necessidades identificadas como mais importante para os servidores. Já a variável satisfação apresentou resultados semelhantes. Contudo, os gestores públicos poderiam dar maior atenção às necessidades fisiológicas, bem como ao fator motivacional, remuneração e benefícios.

Palavras-chave: Gestão de pessoas. Administração pública. Ambiente de trabalho. Fatores de motivação.

NOME: CRISTIANO OLIVEIRA DE SOUZA

TíTULO: ANÁLISE DA ARRECADAÇÃO TRIBUTÁRIA DO MUNICÍPIO DE GLORINHA NO PERÍODO DE 2001 A 2014

RESUMO: Atualmente, os municípios necessitam priorizar ações com foco nas receitas tributárias próprias, as quais o ente municipal tem autonomia, conforme determina a Carta Magna de 1988, e para assim reduzir o grau de dependência das transferências dos demais entes da federação. O objetivo desta tese é analisar a composição e o comportamento das receitas tributárias no município de Glorinha (RS), no período de 2001 a 2014, para identificar potencialidades que visem a ampliação da arrecadação própria do município, e possibilitem planos de ações a serem aplicados na área tributária. A pesquisa aponta que o município obteve um aumento de arrecadação nas transferências intergovernamentais de 366,48\% no período de 2001 a 2014, ocorrida principalmente devido à mudança da economia do município, que antes de 2000 era mais voltada à agricultura e a pecuária e a partir de 2001 entrou em fase de industrialização. Apesar do aumento na arrecadação, verifica-se que existe a possibilidade de criar novas ações a fim de gerar um incremento na receita própria (IPTU, ISS e ITBI) municipal. Pode-se citar como exemplo, na área do IPTU, a necessidade de recadastramento dos imóveis situados na zona urbana através de Geoprocessamento, pois o cadastro encontrava-se desatualizado desde 1999.

Palavras-chave: Orçamento público. Administração pública. Receitas municipais. Impostos e tributos. 


\section{NOME: DALVA APARECIDA BOEIRA VELASQUE \\ TíTULO: IMPACTO DO CURSO TÉCNICO EM GUIA DE TURISMO NA QUALIFICAÇÃO NA PERSPECTIVA DOS EGRESSOS}

RESUMO: A qualificação profissional encontra-se em evidência, considerando-se a competitividade no mundo do trabalho. Houve uma transformação do papel da educação com a inserção das tecnologias de informação e a educação a distância conquistou espaço junto a Instituições de Ensino e percebeu-se o aumento da oferta de cursos técnicos de qualificação profissional. Em 2007, o Governo Federal criou polos de ensino técnico a distância, Polos e-Tec Brasil, para oferta gratuita de cursos técnicos. Constatar o impacto de um curso técnico a distância na vida profissional do egresso e no município constituem-se no objetivo do presente trabalho. Abordou-se o Curso Técnico em Guia de Turismo, ofertado pelo Instituto Federal Farroupilha, Campus São Borja, no Polo e-Tec São Borja (RS). O trabalho contemplou três objetivos específicos: verificar o perfil do estudante ingressante, as influências do curso técnico em sua qualificação profissional e a contribuição do curso para o município na visão do egresso. O procedimento para coleta dos dados ocorreu com uma pesquisa documental no polo presencial e com a aplicação de uma entrevista, enviada por e-mail aos egressos, composta por 23 questões. Verificou-se que houve influência positiva do curso técnico na qualificação profissional, e também que o curso contribuiu para o desenvolvimento do município. Várias foram às vantagens da oferta do curso para o município e para a Região das Missões. Justifica-se a necessidade do curso pelo potencial turístico do município em relação a seu passado histórico, o Primeiro dos Sete Povos das Missões, e berço de dois presidentes brasileiros. Palavras-chave: Educação a distância. Guia de Turismo. Gestão de pessoas. Políticas de educação.

\section{NOME: DANIELA RODRIGUEZ FORTES \\ TíTULO: O AJUSTE DAS FINANÇAS PÚBLICAS À LEI DE RESPONSABILIDADE FISCAL: SANTO ANTÔNIO DAS MISSÕES/RS}

RESUMO: O Estado brasileiro passava por um quadro de crise fiscal nos anos 90 e a criação da Lei de Responsabilidade Fiscal fez parte de um conjunto de medidas para reverter tal situação. A referida Lei impôs ao gestor municipal que tenha responsabilidade fiscal equilibrando as receitas e despesas públicas na execução orçamentária. O presente estudo analisou o impacto da Lei de Responsabilidade fiscal sobre a gestão municipal de Santo Antônio das Missões (RS), verificou o planejamento quanto à receita prevista e arrecadada, o cumprimento dos limites de despesa com pessoal e de dívida e de endividamento. Quanto à transparência e controle social, analisou-se a publicidade dos planos e orçamentos, bem como, a participação popular na elaboração do orçamento e prestação de contas do município. Concluiu-se que o planejamento tem falhado, subestimando ou superestimando as receitas e despesas. A despesa com pessoal ficou dentro dos limites propostos pela referida Lei e o endividamento foi mínimo, sem nunca ultrapassar o estabelecido. Sugere-se que o município revise em que parte do planejamento há falhas, visando o cumprimento da lei e um melhor aproveitamento dos recursos.

Palavras-chave: Lei de Responsabilidade Fiscal. Orçamento público. Auditoria. Administração pública. 
NOME: DAVI BARBOSA DA SILVA

TíTULO: DESENVOLVIMENTOS URBANÍSTICOS DE MUNICÍPIOS: O CASO DO BAIRRO CANUDOS NO MUNICÍPIO DE NOVO HAMBURGO

RESUMO: No Brasil, muitos têm sido os esforços dos órgãos públicos na garantia do direito ao cidadão de uma moradia digna por meio de ações e estratégias de desenvolvimento urbano. Este trabalho se propõe a analisar o desenvolvimento urbanístico nas áreas de interesse social no Bairro Canudos no município de Novo Hamburgo (RS). Descreve a trajetória urbanística, o plano diretor e as principais ações nas áreas de interesse social no Bairro Canudos. Parte da análise de documentos sobre Plano Diretor e Políticas habitacionais implementadas pela Prefeitura de Novo Hamburgo. Propõe possíveis ações para melhorias nos processos urbanísticos no Bairro Canudos. Conclui que as ações do Município demonstram interesse na busca por melhores caminhos para o futuro urbanístico dessa comunidade. Palavras-chave: Plano diretor. Política habitacional. Administração pública.

\section{$\star \star \star$}

NOME: DENISE REGINA DOS SANTOS BARCELLOS

TíTULO: ANÁLISE DOS INSTRUMENTOS DE AVALIAÇÃO DA MATRIZ DE DESENVOLVIMENTO DE LIDERANÇAS DA PREFEITURA DE PORTO ALEGRE

RESUMO: Este estudo tem por objetivo analisar os instrumentos de avaliação utilizados no curso 1 da Matriz de Desenvolvimento de Lideranças da Prefeitura de Porto Alegre (PMPA) para identificar a sua finalidade e se os resultados apurados produziram melhorias. Tratase de uma pesquisa qualitativa, que busca investigar como os cursos que desenvolvem as competências dos gestores da PMPA estão atingindo os seus objetivos. A metodologia para capacitar esses gestores compõe um trabalho inédito na PMPA, cuja lógica está ligada às estratégias do modelo da atual gestão, através de diversas ações conjuntas em diferentes secretarias e órgãos para o melhor aproveitamento dos recursos e resultados para a sociedade. A fonte dos dados pesquisados é governamental e a unidade de trabalho estudada é a Escola de Gestão Pública - EGP, vinculada à Secretaria Municipal de Administração - SMA, que integra a Administração Direta da Prefeitura Municipal de Porto Alegre - PMPA. Os resultados da pesquisa identificaram instrumentos insuficientes para identificar as mudanças esperadas no comportamento dos servidores que participaram dos cursos. Também foi observado que o total de gestores da PMPA é muito alto, situação que requer um planejamento criterioso para a capacitação de todos.

Palavras-chave: Administração pública. Gestão de pessoas. Educação permanente. Avaliação de políticas públicas. 
NOME: DENISE REJANE MELLO DA SILVA

TíTULO: ANÁLISE DA IMPLEMENTAÇÃO DA POLÍTICA DE EFETIVIDADE NA SECRETARIA MUNICIPAL DE SAÚDE DE PORTO ALEGRE

RESUMO: O presente trabalho trata da implementação do sistema de controle eletrônico de efetividade na Secretaria Municipal de Saúde do município de Porto Alegre (RS). A relevância deste tema encontra-se no fato de Porto Alegre (RS) ser o primeiro município no Brasil a implementar o sistema eletrônico de efetividade. São apresentadas questões relacionadas à legislação de pessoal do município, mais especificadamente da categoria dos médicos. A partir da apresentação de como foi realizada a elaboração do projeto do controle eletrônico de efetividade, são descritos os prazos da implementação do projeto e os níveis de efetividade dos servidores municipais da Secretaria Municipal de Saúde. As resistências encontradas na implementação do projeto por parte dos servidores e também por parte das chefias, a metodologia usada no controle de efetividade do Munícipio de Porto Alegre também são abordadas neste trabalho. Questões comportamentais do servidor público e das chefias também foram tratadas, por serem questões fundamentais no processo de mudança e modernização do serviço público. A pesquisa apresenta dados relativos a implementação, os locais onde estão instalados os relógios ponto e o total de servidores que fazem os registros eletronicamente. Palavras-chave: Administração pública. Gestão de pessoas. Ambiente de trabalho. Avaliação de políticas públicas.

\section{NOME: DIEGO SILVESTRIN}

TíTULO: O FINANCIAMENTO DA EDUCAÇÃO BÁSICA E A EXECUÇÃO DA POLÍTICA PÚBLICA DE EDUCAÇÃO INFANTIL NO MUNICÍPIO DE FARROUPILHA-RS

RESUMO: A Lei Federal nํ. 12.796/2013 exigiu mudanças na gestão da educação infantil no município de Farroupilha (RS). Este trabalho teve o objetivo de revelar o processo através do qual a administração municipal se adequou as modificações exigidas pela Lei para possibilitar o atendimento de crianças de 4 e 5 anos na pré-escola na rede pública de ensino básico. Foi realizado um levantamento sobre a legislação referente à educação infantil e de como se constituiu o atual modelo de financiamento da educação básica. Considerando a ideia do ciclo de políticas públicas, coube ao município de Farroupilha a etapa de execução de políticas públicas. Foi realizada uma pesquisa descritiva através do levantamento das receitas vinculadas à educação e dos investimentos necessários para a adequação das exigências do nível pré-escolar. Também foram realizadas entrevistas com a Secretária de Educação e do Conselho Municipal de Educação, elas trouxeram uma descrição de como foi a execução da política pública. Ficou claro o aporte financeiro realizado pelo ente municipal para se adequar à Lei Federal no․ 12.796/2013. Para a manutenção e ampliação de políticas de educação infantil com qualidade é necessário que o repasse de verbas para a educação siga o proposto no Plano Nacional de Educação, aumentando progressivamente até alcançar 10\% do PIB.

Palavras-chave: Administração pública. Políticas públicas. Educação infantil. Financiamento da educação 
NOME: DÓRIS KLASEN

TÍTULO: BENEFÍCIOS DA FORMALIZAÇÃO DO MICROEMPREENDEDOR INDIVIDUAL - MEI: UMA ANÁLISE NA SALA DO EMPREENDEDOR DO MUNICÍPIO DE SÃO LOURENÇO DO SUL

RESUMO: Microempreendedor individual (MEI) é o empresário individual que exerce profissionalmente atividade econômica organizada com receita bruta anual de até $R \$$ $60.000,00$. É optante pelo simples nacional, tendo no máximo um empregado, não possui filial, nem participa de outra empresa como titular, sócio ou administrador. Microempreendedor Individual foi criado através da Lei Complementar Federal 123/2006, que atualizou a Lei Geral da Micro e Pequena Empresa (Lei Complementar Federal 128/2008) e recentemente pela Lei Complementar Federal 147/2014. A Sala do Empreendedor se torna um ambiente propício à formalização. Esta pesquisa pretende analisar os benefícios da formalização do microempreendedor individual (MEI) no município de São Lourenço do Sul (RS), por meio de análise documental realizada na Secretaria Municipal de Turismo, Indústria e Comércio de São Lourenço do Sul. A análise permitiu concluir que os benefícios da formalização do microempreendedor individual em ter registro no CNPJ é o crescimento da atividade econômica: comprar e vender com nota fiscal, o que proporciona melhores preços, realizar vendas para governo, abrir conta em banco como pessoa jurídica, ter acesso a crédito com taxas diferenciadas, receber apoio do SEBRAE e os benefícios previdenciários garantidos.

Palavras-chave: Administração pública. Empreendedorismo. Microempreendedor Individual. Políticas econômicas.

NOME: EDIANE ALINE VATER

TÍTULO: ANÁLISE DOS PARECERES DO TRIBUNAL DE CONTAS SOBRE OS ATOS ADMINISTRATIVOS DO EXECUTIVO MUNICIPAL DE TRÊS PASSOS/RS

RESUMO: O Tribunal de Contas estadual, órgão de controle externo, é o responsável pela fiscalização dos entes públicos municipais quanto ao atendimento da gestão de contas e da gestão fiscal, apontando possíveis irregularidades e emitindo parecer quanto à aprovação ou reprovação das contas. Este trabalho tem como objetivo analisar os pareceres do Tribunal de Contas do Estado do Rio Grande do Sul sobre os atos administrativos do Poder Executivo Municipal de Três Passos, mais especificamente as contas de gestão, ou gestão fiscal, referente aos exercícios financeiros de 2002 a 2010. Nesse sentido, pergunta-se: quais as melhorias ocorridas quanto aos atos e princípios administrativos apontados pelo Tribunal de Contas do Estado referentes ao município de Três Passos? Para responder a essa pergunta, foi realizado um estudo de caso, com abordagem qualitativa, através de pesquisas bibliográficas em fontes primárias e secundarias e análise descritiva de dados de caráter exploratório descritivo. Nos levantamentos de dados foram apresentados dados quantitativos extraídos dos pareces emitidos pela Corte de Contas. Após foi realizada uma análise descritiva dos dados e apontados possíveis motivos e sugestões de melhorias, a fim de diminuir progressivamente os apontamentos da Corte de Contas. Verificou-se que a maioria das mudanças para melhora do quadro atual está na gestão de pessoas, com maior qualificação profissional e adoção de medidas para diminuir a rotatividade de servidores.

Palavras-chave: Orçamento público. Administração pública. Tribunal de Contas. Fiscalização Externa. 
NOME: EDUARDO JOSÉ GOMES

TíTULO: ANÁLISE DOS PROCEDIMENTOS DO PREGÃO ELETRÔNICO NA ADMINISTRAÇÃO MUNICIPAL DE CARAÁ - RS: EXAME DAS POSSIBILIDADES DE MELHORIA

RESUMO: A presente monografia trata sobre a modalidade pregão, na sua forma eletrônica na prefeitura municipal do Caraá (RS). A abordagem foi feita sob o ponto de vista de examinarmos as condições e o contexto deste ambiente licitatório específico, buscando na medida dos resultados encontrados das pesquisas de doutrinas diversas, de jurisprudências, de recomendações do Tribunal de Contas do RS, do Tribunal de Contas da União e da observação direta da estrutura e do delineamento dos procedimentos executados na prefeitura em questão, apresentar sugestões e possibilidades de melhoria para o gestor público municipal nesta área fundamental. Uma boa contratação obtém-se com a proposta mais vantajosa para a administração, ou seja, a economicidade e a vantagem alcançadas aliadas a um eficiente gerenciamento de compras e contratações trarão enormes benefícios para a administração pública municipal e para a sua comunidade em geral.

Palavras-chave: Pregão eletrônico. Lei das licitações. Orçamento público. Administração pública.

$\star \star \star$

NOME: ELIANE CARDOSO OCANHA

TíTULO: GESTÃO DO MEIO AMBIENTE ENVOLVENDO UC DE PROTEÇÃO INTEGRAL O CASO DE SÃO LEOPOLDO-RS

RESUMO: Dada à relevância que a unidade de conservação de proteção integral da natureza denominada Parque Natural Municipal Imperatriz Leopoldina (PNMIL) possui para o município de São Leopoldo (RS), esta pesquisa teve como objetivo investigar a existência de conflitos socioambientais entre os usuários da área de lazer denominada Parque Imperatriz Leopoldina (PIL) e o PNMIL e sugerir medidas efetivas para abrandar, ou até mesmo sanar, estes conflitos. A coleta de dados adotadas na pesquisa fora: a observação, análise de documentos e entrevista com os usuários do PIL. Como principais resultados, identificaram-se que os impactos ambientais ocasionados pela degradação da flora e da fauna da área são ocasionados pelo desconhecimento dos usuários sobre as diretrizes, normas e objetivos do PNMIL, o qual se estende ao PIL. Percebe-se a necessidade de ações direcionadas as áreas através da ampliação dos programas de educação ambiental, acrescidas de medidas administrativas e de fiscalização.

Palavras-chave: Meio ambiente. Políticas públicas. Administração pública. Programas de educação ambiental. 
NOME: ELISABETE LORENSI FERREIRA

TíTULO: ANÁLISE DE QUALIDADE DO CONTEÚDO DO SITE DO OBSERVATÓRIO DA CIDADE DE PORTO ALEGRE (OBSERVAPOA)

RESUMO: Esta pesquisa apresenta o Observatório da cidade de Porto Alegre (ObservaPoa), que surgiu a partir da necessidade de divulgar informações da Administração Pública e possibilitar maior transparência nos atos e processos de gestão de políticas públicas. Para isso, é fundamental que o conteúdo informacional disponibilizado nos Observatórios seja de qualidade. O objetivo geral foi avaliar a qualidade do conteúdo do site do ObservaPoa, a partir dos critérios de qualidade abrangência/ cobertura, propósito e atualidade, da página inicial até o terceiro nível. Realiza como complementação da avaliação a análise de atualidade e completeza dos indicadores constantes no mesmo site, comparando com diferentes fontes de informação. A partir dos resultados da pesquisa, conclui-se que o estudo pode servir de subsídio para melhorias que resultariam em um espaço de divulgação com maior qualidade e que atenda melhor às expectativas informacionais do cidadão.

Palavras-chave: Avaliação da informação. Observatórios municipais. Indicadores sociais. Administração pública

NOME: EUNICE KINZEL

TíTULO: A ORGANIZAÇÃO DO TURISMO: UMA ANÁLISE DO MUNICÍPIO DE TRÊS COROAS - RS

RESUMO: Esta monografia tem o objetivo de buscar melhorias ao desenvolvimento do turismo na cidade de Rolante, localizada no Vale do Paranhana (RS). Para isso estudou-se a organização da cidade de Três Coroas, a mais desenvolvida turisticamente nesta mesma região. Os diversos eventos do município que atraem milhares de pessoas anualmente, eventos sociais e de valorização cultural e de grupos, alguns realizados em períodos de baixa sazonalidade, faz usufruir do comércio local, restaurantes, pousadas e hotel. Alguns atrativos turísticos públicos têm participação da iniciativa privada com muito bom andamento e organização. A iniciativa privada está mais presente na cidade de Três Coroas, localizada no eixo turístico da Serra Gaúcha e próxima à cidade de Gramado. O mapeamento dos atrativos e eventos turísticos de Três Coroas, a análise dos investimentos públicos foram questões pormenorizadas no texto. Com o levantamento dos dados foi comparado aos eventos e atrativos turísticos de Rolante, que se localiza no eixo litoral, onde milhares de pessoas que semanalmente vão às praias, passam pela RS 474 e RS 239 que cortam o município de Rolante. Nas análises sistematizadas foi possivel encontrar contribuições para fomentar o turismo em Rolante. É possível buscar um nicho a esse turista, para que ele desvie sua rota alguns minutos e vá até a sede do município. Importante a continuidade de investimentos públicos ao turismo municipal além da parceria público- privada frente ao crescimento do turismo no município de Rolante.

Palavras-chave: Turismo. Orçamento público. Administração pública. Políticas públicas. 
NOME: FABIANA RIBEIRO

TÍTULO: FORMAÇÃO CONTINUADA DOS PROFESSORES DO MUNICÍPIO DE SÃO LEOPOLDO: UMA ANÁLISE A PARTIR DA PERCEPÇÃO DOS PROFISSIONAIS DA ÁREA DA EDUCAÇÃO.

RESUMO: O presente trabalho aborda aspectos da Formação Continuada dos professores da Educação Básica do Município de São Leopoldo (RS). O trabalho teve como objetivo geral conhecer como se ocorreu o investimento na formação continuada dos professores da Educação Básica dessa rede no biênio 2013-2014, descrever as expectativas dos docentes em relação aos cursos de formação continuada, a metodologia que cada gestor adota para a formação continuada, se esta ocorrer. Estende-se um olhar reflexivo acerca do Plano de Cargos e Carreiras do Município, assim como também sobre as Normativas e Resoluções apresentados pelo Governo Federal em relação à Formação dos docentes, assim como um comparativo com a educação do Reino Unido. As etapas do trabalho consistem em pesquisa de campo com 40 professores do $1^{\circ}$ ao $5^{\circ}$ ano do Município de São Leopoldo. O método utilizado foi o recurso de um questionário, em que se realizou uma análise quantitativa e qualitativa acerca do questionário aplicado das 4 escolas entrevistadas. Os principais resultados da pesquisa foram bastante satisfatórios, uma vez que a Secretaria Municipal de Educação proporciona periodicamente encontros de formação. Os professores demonstraram interesse e envolvimento nas formações realizadas. Outro aspecto positivo da pesquisa é o fato dos gestores das escolas oportunizarem momentos de formação, além dos que já oferecidos pela mantenedora. O que enriquece o trabalho pedagógico destes profissionais. Palavras-chave: Formação continuada. Educação Básica. Políticas de educação. Administração pública.

\section{NOME: FÁBIO RICARDO CARDOSO MAGALHÃES \\ TÍTULO: O ALINHAMENTO DO PLANEJAMENTO GOVERNAMENTAL FEDERAL COM O MU- NICIPAL DE ALGUNS MUNICÍPIOS DO RS}

RESUMO: Esta pesquisa tem como objetivo verificar se o alinhamento técnico do planejamento governamental da esfera federal (PPA 2012-2015) com a esfera municipal (PPAs 2014-2017) de alguns municípios do Estado do Rio Grande do Sul (São Francisco de Paula, Cambará, Taquara, Parobé, Pelotas e Canoas), através da ferramenta Technology Roadmapping (TRM), garantiria uma posição privilegiada na captação de recursos federais. Para isto, foi realizada uma revisão teórica do planejamento governamental adotado pelo governo federal e da aplicabilidade desta ferramenta gráfica. A partir da TRM, que é um método de gerenciamento utilizado para suportar o planejamento estratégico tecnológico em empresas, foram elaborados o mapa do alinhamento de planejamento (TRM), a tabela de pontuação de alinhamento, de planejamento e o indicador de alinhamento ( $\mathrm{R} \$ /$ habitante) por município, demonstrando uma contradição entre o mapa e o indicador. Analisando os dados, foi possível constatar que os recursos de convênio (esforço de planejamento) representavam $2 \%$ do total da receita federal (98\% da receita com pouco esforço de planejamento). Conclui-se que o sistema atual não estimula o esforço de alinhamento de planejamento, resultando gestões com baixa efetividade, eficiência e eficácia. A frágil governabilidade, devido aos projetos de governo sem visão estratégica e sem participação social, dificulta a capacidade de governar e de ganhar o apoio político da população.

Palavras-chave: Administração pública. Plano plurianual. Governabilidade. Políticas públicas. 
NOME: FERULIO JOSE TEDESCO

TÍTULO: A TRANSPARÊNCIA NO MUNICÍPIO DE SANTO ANTÔNIO DA PATRULHA APÓS A LEI N.ำ 12.527/11

RESUMO: Este trabalho tem como objetivo analisar a implantação da Lei de Acesso à Informação e a percepção do Portal de Transparência por servidores municipais, lideranças representativas e setor empresarial do município de Santo Antônio da Patrulha (RS). A questão fundamental de cumprir o princípio da transparência está intimamente ligada à disponibilização de informação pelos órgãos e entidades governamentais. Analisou-se como estão sendo disponibilizadas as informações no portal de transparência, no que se refere à universalização, à fácil compreensão, qualidade e periodicidade das informações. São apresentados resultados de pesquisa realizada por meio eletrônico, colhendo opiniões de usuários, servidores e público em geral, de assuntos ligados à transparência pública. Entre os principais, ressalta-se o elevado desinteresse, ou desconhecimento, sobre o tema e a opinião amplamente favorável à divulgação das informações pelo portal e à utilização de consulta da população, por meio eletrônico. Registra-se, que o município tem se destacado pelo atendimento de grande parte das exigências da LAI, conforme levantamento do TCE/RS. Considera-se que não basta dispor a informação; é necessário estimular a participação dos servidores e da sociedade para exercer essa nova forma de cidadania e de controle social. Palavras-chave: Lei de Acesso à Informação. Administração pública. Cidadania. Participação social.

NOME: FRANKLIN DE ALMEIDA CARL

TÍTULO: PLANEJAMENTO E ORÇAMENTO: O CONTROLE SOCIAL NO PROCESSO DE TRANSPARÊNCIA DAS FINANÇAS PÚBLICAS MUNICIPAIS EM PORTO ALEGRE.

RESUMO: O presente trabalho objetivou caracterizar e analisar os instrumentos, disponíveis no arcabouço legal brasileiro, que subsidiam o controle social das finanças públicas e influenciam a transparência das finanças no município de Porto Alegre (RS) à luz da Constituição Federal e da Lei de Responsabilidade Fiscal, no que tange aos instrumentos de gestão responsável, tendo como pressuposto a ação planejada e transparente. Para o entendimento deste conjunto de elementos, que possibilitam o acompanhamento da gestão financeira pública por parte da sociedade, foram abordados diversos instrumentos, tais como o Relatório Resumido de Execução Orçamentária, o Relatório de Gestão Fiscal e as prestações de contas, consolidados e elaborados de acordo com as normas brasileiras de contabilidade pública. A presente análise mostrou-se relevante em face da importância do controle nas ações governamentais, tendo como foco o incentivo à participação popular. Foram explorados os atuais meios de acesso às informações e o caminho para o qual esse tema caminha. A técnica utilizada foi pesquisa documental e bibliográfica e foi elaborado um diagnóstico descritivo-qualitativo dos instrumentos utilizados pelo município de Porto Alegre. O resultado do estudo indicou que os instrumentos que subsidiam e instrumentalizam o controle social influenciam a transparência das finanças públicas através da disponibilização de informações financeiras e orçamentárias, cuja disponibilização abrangente ocorreu após aplicação da Lei de Responsabilidade Fiscal. Palavras-chave: Administração pública. Orçamento público. Lei de Responsabilidade Fiscal. 
NOME: GILCEU RIBAS DE CAMPOS

TíTULO: UM ESTUDO SOBRE OS EVENTOS QUE ANTECEDERAM A LICITAÇÃO DO SERVIÇO DE TRANSPORTE COLETIVO POR ÔNIBUS DO MUNICÍPIO DE PORTO ALEGRE

RESUMO: Este trabalho faz uma análise dos eventos que antecederam a licitação do Sistema de Transporte Público de Passageiros por Ônibus da cidade de Porto Alegre (RS), adiada por 25 anos. Sendo o Brasil um Estado de Direito e sendo uma república, torna-se fundamental que a lei seja observada e a vontade popular seja levada em consideração na implantação e na prestação dos serviços públicos. Neste trabalho, foram identificados os instrumentos que regulam o setor de transporte público por ônibus; foram apontadas as principais irregularidades identificadas pelo Tribunal de Contas do Rio Grande do Sul - TCERS que auditou a Empresa Pública de Transportes e Circulação - EPTC, nos exercícios de 2011 e 2012, foi analisada a influência das manifestações de junho de 2013, na redução da tarifa do transporte público por ônibus, em Porto Alegre e por fim analisou-se a ação civil pública, que obrigou a Prefeitura de Porto Alegre a realizar a licitação do Transporte Público de Passageiros por Ônibus. Os procedimentos metodológicos aplicados foram do tipo estudo de caso e a técnica utilizada para levantamento das informações foi a pesquisa bibliográfica e documental. Ao final da pesquisa, concluiu-se que o poder público abriu mão do poder regulamentar sobre esse serviço público e é de suma importância tornar a participação popular eficaz e eficiente na fiscalização da coisa pública.

Palavras Chaves: Administração pública. Orçamento público. Políticas de transporte urbano. Lei das licitações.

NOME: GRAZIELA FORTES DA ROCHA

TÍTULO: COMO OS GESTORES DO MUNICÍPIO DE SANTIAGO/RS BUSCAM E UTILIZAM A PARTICIPAÇÃO POPULAR COMO FORMA DE A MELHORIA DA MOBILIDADE URBANA NO MUNICÍPIO.

RESUMO: O presente trabalho de conclusão, busca expor como a participação popular é utilizada como fonte de melhoria das condições de mobilidade urbana no município de Santiago (RS), fazendo um levantamento de como são colhidas as intenções populares, e como a atual situação do Município, no quesito mobilidade urbana demonstra a participação da sociedade do Município, se a Administração estava levando em conta a participação popular como uma das metas impostas aos Municípios que compõe o rol das Cidades Educadoras, buscando avaliar se a participação popular de fato é utilizada em prol da população Municipal, como forma de construção da democracia entre os Munícipes.

Palavras-chave: Administração pública. Orçamento público. Políticas de transporte urbano. 
NOME: IVANISCE CHRIST

TÍTULO: PROFISSIONALIZAÇÃO DO SERVIDOR PÚBLICO ESTÁVEL DO MUNICÍPIO DE BARÃO: A IMPORTÂNCIA DA QUALIFICAÇÃO PROFISSIONAL DOS OCUPANTES DE CARGOS DE NÍVEL MÉDIO.

RESUMO: Considerando a importância da profissionalização, a necessidade de qualificar o servidor estável de nível médio do município de Barão (RS) e a complexidade dos serviços públicos prestados, pesquisou-se qual a percepção desses servidores sobre a sua profissionalização. Neste estudo abordou-se a preocupação com a profissionalização do servidor, uma vez que a administração pública necessita melhorar substancialmente a qualidade dos serviços prestados à sociedade e, a necessidade de instituir estratégias para motivar os servidores a buscarem a qualificação necessária ou desejada. Trata-se de um estudo de caso, com abordagem qualitativa. A coleta de dados foi realizada a partir da aplicação de um questionário e análise das fichas funcionais. Com base nestes dados, procurou-se identificar quantos servidores buscaram a profissionalização após o ingresso no serviço público, apontar estratégias que possam incentivá-los a profissionalizarem-se e, enumerar as razões pelas quais não promovem a ampliação de seus níveis de ensino. Após aplicação do questionário e análise dos dados obtidos constatou-se que, em um pequeno número de servidores, houve um aumento do nível de ensino desde o ingresso no serviço público. Ressaltando ainda, que a ausência de incentivos financeiros por parte da Prefeitura Municipal, é o principal motivo por não buscarem ampliação dos seus níveis de ensino. Como estratégia de incentivo os servidores requerem aumento salarial para aqueles que aumentarem o nível de escolaridade previsto no Plano de Carreira dos Servidores Públicos do município de Barão.

Palavras-chave: Administração pública. Políticas de educação. Ensino médio. Gestão de pessoas.

NOME: JAMINE FERNANDES MACHADO

TíTULO: A RELAÇÃO ENTRE O DESEMPENHO DOS SERVIDORES E OS SERVIÇOS PRESTADOS PELO DEPARTAMENTO DE ÁGUA DA PREFEITURA MUNICIPAL DE CARAÁ - RS

RESUMO: O desempenho dos servidores efetivos no setor público tem apresentado algumas particularidades. Ao contrário do que acontece no setor privado, onde o gestor pode contratar profissionais que apresentam características vantajosas para a empresa, no setor público, a Constituição Federal, em seu artigo 41, exige que as contratações sejam feitas mediante concurso público. O presente estudo teve por objetivo geral compreender a relação entre capacitação e desempenho dos servidores do Departamento de Água do Município de Caraá (RS) e a qualidade dos serviços prestados aos munícipes. Para tanto, foi realizada uma pesquisa a partir da aplicação de dois questionários, sendo um voltado aos usuários dos serviços e outro aos servidores do departamento. Como principais resultados pode-se apontar que os usuários dos serviços do Departamento de Água encontram-se satisfeitos com o atendimento e a qualidade dos serviços, porém, apontam, em linhas gerais, que há necessidade de melhorias tais como aquisição de novos equipamentos e oportunidade de qualificação. Já os servidores apontam a necessidade de capacitação para melhor atender às demandas dos munícipes.

Palavras-chave: Administração pública. Gestão de pessoas. Educação permanente. Qualidade de serviços públicos. 
NOME: JÉSICA HENCKE

TíTULO: GESTÃO DEMOCRÁTICA NA EDUCAÇÃO INFANTIL: UM INÉDITO VIÁVEL OU A FALÁCIA ADMINISTRATIVA?

RESUMO: Dentro de uma concepção democrática de gestão educacional os objetivos, a concepção filosófica, os métodos de trabalho e a organização pedagógica são interdependentes e precisam ser pensados de forma conjunta, visto que demarcam as posturas assumidas pela instituição de ensino. A intenção desta pesquisa é identificar, num estudo de caso, como os docentes e gestora, se percebem enquanto indivíduos ativos e participativos da gestão escolar na instituição onde trabalham. A investigação ocorreu em uma escola de educação infantil pertencente ao município de Canela (RS). Nesta pesquisa, ouviram-se docentes e corpo diretivo acerca do que entendem por e como ocorre o processo de gestão escolar. As falas foram articuladas com referenciais bibliográficos que tratam desta temática, com o projeto político pedagógico da instituição e com a lei municipal que estabelece as incumbências do gestor/diretor escolar. Elencou-se como problemática de pesquisa a gestão democrática na educação infantil como uma possibilidade a ser assumida, conquistada e qualificada enquanto processos de participação, autonomia e democracia ou, uma falácia como conceito filosófico que abrange um raciocínio errôneo com aparência de verdade e macula o que de fato ocorre como processo de gestão escolar. Obteve-se como resultado um conhecimento superficial e distorcido do que é gestão democrática, minimizado a esfera da participação. As docentes entrevistadas (há apenas professoras nesta escola) apresentaram boa articulação no que se refere ao trabalho da gestora, não se omitiram da responsabilidade no desenvolvimento de ações que visam qualificar o processo de aprendizagem na educação infantil. Como conclusão, que a gestão democrática não é mais uma falácia administrativa e sim, uma possibilidade de conquista deste inédito viável.

Palavras chave: Administração pública. Gestão democrática. Educação infantil. Participação. Políticas de educação.

\section{NOME: JOCIANE FRANS POLGA AURÉLIO \\ TÍTULO: CONTROLE INTERNO NA ADMINISTRAÇÃO PÚBLICA MUNICIPAL: UM ESTUDO DE CASO DO MUNICÍPIO DE SANTIAGO/RS}

RESUMO: O presente artigo tem como objetivo a reflexão teórica através de um estudo de caso sobre regulamentação e implantação do sistema de controle interno, primeiramente em âmbito nacional, trazendo posteriormente para a realidade em nível municipal e, neste caso, para o Município de Santiago (RS). Neste estudo são abordadas as especificidades de métodos teóricos sobre controles, controle interno, controle externo, controle social, processos de gestão e de tomada de decisão tanto quanto são apontadas particularidades e afinidades entre estes e a realidade praticada na esfera municipal. A metodologia adotada constitui-se de pesquisa teórica, articulada através da revisão da bibliografia e da legislação na esfera federal e municipal sobre controle interno (objetivos e finalidades), caracterizando a pesquisa como descritiva, através da qual foi possível descrever as aplicabilidades teórico -práticas verificadas junto à Unidade Central de Controle Interno de Santiago. O resultado principal diz respeito à caracterização do sistema de controle interno e sua atuação em âmbito municipal, diante das características encontradas e ações realizadas pela Unidade. Palavras-chave: Controle interno. Gestão. Tomada de decisão. 
NOME: JOSÉ CARLOS BOURSCHEID

TÍTULO: A AUTONOMIA DO CONSELHO MUNICIPAL DE SAÚDE DE TRÊS PASSOS

RESUMO: O presente estudo busca compreender o nível de autonomia do Conselho Municipal de Saúde do município de Três Passos (RS) e sua contribuição para a organização e implementação do Sistema Único de Saúde. De acordo com os estudos de documentos e depoimentos dos conselheiros, foram levantadas informações importantes para entender o processo de articulação e participação popular na implantação de um novo modelo de política pública para a saúde local e a existência de autonomia do conselho. Utilizando-se a metodologia de estudo de caso, na linha qualitativa, foram entrevistados conselheiros que contribuíram na organização do Conselho e seus processos deliberativos. A pesquisa busca entender o processo deliberativo do conselho e tem como objetivo analisar a existência de autonomia externa no exercício de suas competências. Os resultados do referido estudo mostram que houve o envolvimento expressivo da sociedade na construção do Sistema Único de Saúde e hoje, mostra-se fragilizado na renovação de lideranças e participação social. Revela-se um Conselho com agenda pouco propositiva, com mínima autonomia externa em seu processo deliberativo. Palavras-chave: Sistema Único de Saúde. Conselho Municipal de Saúde. Controle social. Administração pública. Políticas de saúde.

NOME: JOSÉ FABIANO ROSSI

TíTULO: GESTÃO DO DESEMPENHO NOS PROGRAMAS ESTRATÉGICOS GOVERNAMENTAIS DA PREFEITURA DE PORTO ALEGRE: A MATRIZ DE RESULTADOS (EGPE) E A QUESTÃO DO BAIXO DESEMPENHO

RESUMO: O presente trabalho é um estudo a respeito desempenho nos Programas Estratégicos de Governo da Prefeitura Municipal de Porto Alegre (PMPA). O objetivo principal da pesquisa é expor a questão do baixo desempenho de Programas frente aos critérios de medição da ferramenta Matriz de Evolução Gerencial dos Programas Estratégicos (Matriz EGPE), apontando aspectos críticos do processo de avaliação, estabelecendo relações entre a avaliação, a "problemática" da baixa pontuação e a possibilidade de melhorias e soluções. A pesquisa utilizou-se de técnica de coleta de dados com a aplicação de um questionário e realização de entrevista. $\mathrm{Na}$ análise teórica, foram tratados conteúdos que dizem respeito ao Balanced Scorecard (BSC), à Gestão por Resultados e ao BSC adaptado à PMPA. Também foi feita a discussão teórica, onde foram abordados conceitos considerados relevantes para a pesquisa, como o conceito de desempenho e de avaliação. Ao apresentar a análise de dados coletados, foram apontados problemas e dificuldades relacionados à avaliação de desempenho dos Programas Estratégicos. Após o levantamento e análise dos dados, foram constatadas evidências de que o modelo de avaliação, os métodos e a ferramenta utilizada para medição e avaliação de desempenho trabalham em uma sistemática que, segundo os profissionais que atuam nos Programas, necessita ser melhor ajustada, para que se trabalhe com mais precisão e maior proximidade à realidade de cada Programa. Além disso, a pesquisa constatou que é necessário buscar soluções que possam repercutir em melhor desempenho, sendo que estas necessidades se concentram nos aspectos de pessoas, equipes de trabalho e sinergia entre as áreas que atuam nas etapas dos Programas. Palavras-chave: Avaliação. Gestão de desempenho. Balanced Scorecard (BSC). Planejamento estratégico. Modelo de gestão. Administração pública. 
NOME: JULIANA MICHELE SILVANO CABRERA

TíTULO: REGULARIZAÇÃO FUNDIÁRIA: A APLICAÇÃO DO ESTATUTO DA CIDADE NO MUNICÍPIO DE SAPIRANGA

RESUMO: Considerando a questão habitacional brasileira, e de que a moradia é um direito do cidadão e é dever da Administração Pública proporcionar o bem-estar da população. Temse a regularização fundiária como forma de minimizar o contexto atual, proporcionando o direito à terra urbanizada. Assim, estudou-se os loteamentos consolidados no município de Sapiranga, em conjunto com a aplicação da legislação disponível, em especial ao Estatuto da Cidade. A coleta de dados foi realizada a partir da observação e análise de documentos disponíveis na Prefeitura, com o objetivo de identificar e classificar as irregularidades. Os resultados obtidos são de que a legislação está aplicada em alguns casos e que os poderes executivo, legislativo e judiciário necessitam de entendimento em conjunto e que a partir dos dados levantados é possível projetar ações futuras para viabilizar a solução do problema. Sugere-se a continuidade de estudo dessa natureza para aprofundar o assunto e explorar os demais instrumentos previstos no Estatuto da Cidade.

Palavras-chave: Administração pública. Políticas públicas. Estatuto da Cidade. Política habitacional.

NOME: JULIANA MICHELLON

TíTULO: ANÁLISE DA FORMALIZAÇÃO DE CONVÊNIO PARA GESTÃO DA EDUCAÇÃO INFANTIL PÚBLICA: UM ESTUDO DE CASO NO MUNICÍPIO DE DOIS IRMÃOS - RS

\section{RESUMO:}

Este estudo apresenta o contexto da Educação Infantil no município de Dois Irmãos, onde existe dificuldade em ofertar vagas. Para cumprir o seu dever constitucional, o município firmou convênio com a Fundação Assistencial de Educação Infantil de Dois Irmãos - FADI. Este estudo apresenta a relação estabelecida entre a Fundação e o Poder Público, diante do artigo 116 da Lei 8666/93. Apresenta também os conceitos de custos, em particular a metodologia de custeio por absorção, e fazendo uso desta ferramenta observou-se o custo anual da FADI para atender as 821 crianças e o custo das escolas de educação infantil públicas, para atender as 151 crianças. Analisando o custo aluno/ano, constatou-se que o custo maior está na Educação Infantil pública, e que a maior discrepância ocorre no custo de pessoal. Palavras-chave: Administração pública. Orçamento público. Políticas de educação. Educação infantil. 
NOME: JULIANA OLIVEIRA CORRÊA

TíTULO: ANÁLISE DOS PROCEDIMENTOS DE GESTÃO NA MANUTENÇÃO DAS VIAS PÚBLICAS NÃO PAVIMENTADAS: ESTUDO DE CASO NO MUNICÍPIO DE CANELA/RS

RESUMO: Este trabalho tem como tema a análise dos procedimentos de gestão na manutenção de vias não pavimentadas no município de Canela/RS. Com a proposta de mostrar que com gestão, conhecimentos orçamentários e monitoramentos documentais é possível a redução dos gastos, assim como descrever a importância da eficácia na programação dos gastos públicos, desenvolvendo alternativas de redução dos mesmos. Para contextualizar o estudo apresenta-se um referencial teórico em relação à importância da gestão, da administração pública no Brasil: patrimonialista, burocrática e gerencial, em seguida são apresentados os gastos na administração pública, o orçamento público municipal, os tipos de despesas conhecidas, as limitações dos gastos e a eficácia na programação dos gastos na administração pública. A pesquisa utilizou como referências um estudo de caso com uma análise de orçamentos específicos, uma entrevista, para análise pela visão dos servidores responsáveis pela manutenção das vias públicas e os apontamentos observados pela autora, com objetivo de identificar o ambiente de gestão a ser estudado. Como resultados, confrontados com o referencial teórico pesquisado, conclui-se que é possível reduzir os gastos na manutenção das vias públicas não pavimentadas, através de uma gestão com programação de gastos públicos, porém, percebe-se a necessidade de aprimorar o sistema da Secretaria Municipal de Obras e Planejamento, recomenda-se um maior monitoramento documental de materiais bem como um trabalho de apoio por parte dos servidores.

Palavras-chave: Administração pública. Orçamento público. Políticas de transporte urbano.

NOME: JÚLIO CÉSAR BRIXNER

TÍTULO: IMPACTOS DA POLÍTICA NACIONAL DE RESÍDUOS SÓLIDOS (PNRS) NO MUNICÍPIO DE SAPUCAIA DO SUL

RESUMO: A Política Nacional de Resíduos Sólidos é ampla e atinge a questão do tratamento dos resíduos sólidos em todas as suas dimensões: social, econômica, ambiental, de infraestrutura, gerencial e territorial. Ademais, articula ações de empresas, entes governamentais, gestores e da sociedade em geral em torno do objetivo de reduzir a geração de resíduos - como embalagens, por exemplo - e também incentivar o reaproveitamento de materiais através da reciclagem. Este estudo de base exploratória demonstra os principais avanços na implantação da Política Nacional de Resíduos Sólidos no município de Sapucaia do Sul (RS), evidenciando a adequação do município à norma federal. O impacto causado pelos resíduos sólidos no meio ambiente, seu custo, não só monetário como também referente à degradação do meio ambiente e à saúde da população estão demonstrados através da pesquisa e análise de informações obtidas junto às autoridades municipais responsáveis. Também contempla a destinação correta de rejeitos e matéria úmida (lixo doméstico orgânico), destacando sua amplitude em relação ao município, tema central do curso. Estão demonstradas as ações postas em prática pela Administração Municipal, assim como os pontos onde esta pode evoluir.

Palavras-chave: Política Nacional de Resíduos Sólidos. Administração pública. Orçamento público. 
NOME: JULIO CÉSAR CORINO

TíTULO: AVALIAÇÃO DA ATUAÇÃO DA VIGILÂNCIA SANITÁRIA MUNICIPAL DE SÃO FRANCISCO DE PAULA REFERENTE AO QUEIJO SERRANO

RESUMO: O presente trabalho tem como objetivo analisar as ações desenvolvidas pela Secretária da Saúde de São Francisco de Paula (RS), no que se refere à atuação da Vigilância Sanitária Municipal em relação ao Queijo Artesanal Serrano nos pontos de comercialização ao longo das rodovias RS-020 e RS-453 (Rota do Sol) nos trechos que cortam o município, especificamente em relação à garantia da qualidade e origem que é ofertada aos consumidores, que buscam este produto tradicional da região por seu sabor característico e existência secular, frente aos riscos potenciais a saúde pública pelo fato de ser produzido necessariamente com leite "in natura" e instalações mínimas nas próprias fazendas. Respondendo a pergunta se é possível a Vigilância Sanitária Municipal garantir a inocuidade deste "patrimônio cultural", agregando valor sanitário ao valor cultural-social com os recursos e estrutura para ela disponibilizada. O método utilizado para o desenvolvimento do estudo é uma pesquisa descritiva no que diz respeito ao objetivo a ser alcançado, utilizando dados da Secretária Municipal da Saúde, Secretária da Agricultura, Pecuária e Agronegócio do estado do Rio Grande do Sul, Empresa de Assistência Técnica e Extensão Rural e revisão bibliográfica sobre o tema. Concluiu-se que a Vigilância Sanitária Municipal não exerce seu papel orientador e fiscalizador, não garantindo a origem e inocuidade deste produto.

Palavras-chave: Vigilância Sanitária. Políticas de saúde. Administração pública. Saúde pública.

NOME: LAÉRCIO ARNALDO SCHLEME

TÍTULO: ANÁLISE DO IPTU E OS IMPACTOS CAUSADOS NAS FINANÇAS DO MUNICÍPIO DE TRÊS PASSOS-RS

RESUMO: Esse trabalho relata o estudo do problema que acarreta a inadimplência do Imposto Predial Territorial Urbano (IPTU) no Município de Três Passos (RS). Apresenta os dados numéricos referentes a arrecadação e dívida ativa do período de 2006 a 2014 . Foi feito um levantamento de dados junto à Secretaria Municipal de Tributação do Município de Três Passos para demonstrar, em gráficos e tabelas, a evolução da dívida, sendo considerado para fins de estudo os últimos cinco anos, cujo volume de recursos representa $R \$ 1.714 .930,67$. Sendo que, os dois últimos anos são os mais preocupantes, porque representam a grande parte da dívida assim como está demonstrado tanto em tabelas como gráficos. Diante da situação foram constatadas algumas causas tanto do aumento do imposto como da inadimplência. E tal situação de falta de receita acaba se refletindo em toda a municipalidade, impactando diretamente nos investimentos em saúde que representam quinze por cento desse valor, em educação que representa vinte e cinco por cento e o restante dos sessenta por cento nas demais estruturas necessárias para o bom funcionamento da máquina pública.

Palavras-chave: Imposto Predial Territorial Urbano. Administração pública. Orçamento público. 


\section{NOME: LEANDRO ALEX MISSAGIA FERNANDES \\ TíTULO: POLÍTICA PÚBLICA DE PREVENÇÃO PRIMÁRIA À DROGADIÇÃO NAS ESCOLAS MUNICIPAIS DE NOVO HAMBURGO: O PROERD}

RESUMO: O abuso de drogas entre jovens é uma das questões que mais aflige a sociedade contemporânea. O município tem o dever de proliferar ações de prevenção como medida protetiva em diferentes áreas (educação, assistência social e saúde). O objetivo maior da monografia é analisar a contribuição de uma política de prevenção primária no combate à drogadição de crianças e adolescentes em algumas escolas da rede pública municipal de ensino fundamental de Novo Hamburgo, o Programa Educacional de Prevenção e Resistência às Drogas (PROERD). O referencial teórico discorre sobre conceitos e tipos de políticas públicas e descreve o Sistema Nacional de Política sobre Drogas. Aborda o PROERD, sua origem, objetivos e metodologia de ensino. No estudo, utilizou-se o método da pesquisa qualitativa, segundo sua natureza e descritiva, no que diz respeito aos objetivos, com análise dos conteúdos, permitindo o enfoque intuitivo no exame dos dados coletados. Realizadas entrevistas, com professores de seis escolas municipais e policiais instrutores do PROERD, na análise de dados, observa-se que o programa caminhou lentamente nesse Município. Com o reconhecimento do programa como uma política pública, na publicação da Lei Municipal nํ. 2.538/2013, o PROERD passou a ser efetivamente aplicado nas escolas do Município. Conclui-se que este é o principal Programa Educacional de Prevenção e Resistência às Drogas, desenvolvido nas escolas, em ação conjunta da Brigada Militar e a Secretaria Municipal de Educação, com metodologia diferenciada, contribuindo para o crescimento saudável dos jovens, transmitindo informações sobre os riscos das drogas e ensinando como resistir às pressões dos grupos na oferta de drogas e atos violentos. Palavras-chave: Políticas de saúde. Programa Educacional de Prevenção e Resistência às Drogas. Drogadição. Saúde pública.

NOME: LÉO FIORIO

TíTULO: AVALIAÇÃO DA SATISFAÇÃO DA PRESTAÇÃO DO SERVIÇO DA GUARDA MUNICIPAL DE VACARIA-RS

RESUMO: Este trabalho tem como objetivo avaliar a satisfação da prestação do serviço público realizado pela Guarda Municipal de Vacaria. Essa proposta permite vislumbrar a percepção da satisfação dos servidores (público interno) e dos usuários (público externo) a respeito do serviço ofertado pela instituição pública. Para contextualizar o estudo utilizou-se o embasamento legal nas legislações federais, estaduais e municipais existentes acerca das Guardas Municipais no Brasil, enfocando a sua evolução no cenário da Segurança Pública bem como a percepção da prestação do serviço público através de referencial bibliográfico. Como base de pesquisa realizou-se a confecção de questionários através da aplicação do método de survey a fim de coletar os dados referente a percepção da satisfação da prestação de serviço público para a comunidade de Vacaria. No estudo abordam-se ainda as sugestões e demandas percebidas com a realização das análises dos resultados sugestionando melhorias ao gestor público para futura implantação.

Palavras-chave: Administração pública. Orçamento público. Gestão de pessoas. Qualidade. Política de segurança pública. 
NOME: LUCIANO LUÍS FLORES

TíTULO: A ANÁLISE DO PLANO DE EDUCAÇÃO MUNICIPAL DE XANGRI-LÁ/RS E SUA APLICAÇÃO SEGUNDO O QUE ESTABELECEU O PLANO NACIONAL DE EDUCAÇÃO NO PERÍODO DE 2005 A 2014

RESUMO: O caminho para que uma política de educação se alicerça e que seja capaz de sustentar uma ação educativa coerente, eficaz e reconhecida por uma comunidade escolar, nasce a partir de seu planejamento, de seu plano de educação municipal. Concebem-se como integrantes da comunidade escolar: estudantes e suas famílias, professores, funcionários de escola e equipe diretiva e pedagógica, que compreendem que a escola não é apenas uma soma de parceiros, de recursos e de atividades ritualizadas, mas é uma instituição de formação social, em interação com o meio envolvente e que está permanentemente em mudança, buscando seu melhor. Este instrumento deve, enquanto referencial de pensamento e ação desta localidade, possuir determinados princípios, metas e objetivos educacionais, balizados e orientados na intervenção de todos os agentes envolvidos com a escola. O presente trabalho objetivou analisar o plano de educação municipal de Xangri-lá (RS) e sua aplicação, segundo o que estabeleceu o plano nacional de educação, no período de 2005 a 2014. Após a análise da literatura buscou-se conhecer quais as metas e objetivos que foram alcançados, como também as que permanecerão sendo objetos de busca e de constante avaliação. Em conclusão constatou-se que houve grandes avanços na Educação Infantil, como ampliação de vagas e melhorias nos espaços de atendimento. No Ensino Fundamental, o ensino de nove anos e formulação do projeto político pedagógico. $\mathrm{Na}$ formação continuada e valorização dos profissionais do magistério, implantou-se novo plano de carreira. Relativo a educação especial, quase nada se avançou e na educação de jovens e adultos, a modalidade deixou de ser ofertada em 2009. Muito ainda há de se conquistar, para que o município alcance as metas propostas com excelência e qualidade.

Palavras-chave: Administração pública. Orçamento público. Políticas de educação. Educação.

NOME: LUIZ ERNANI SACHSER

TÍTULO: ESTUDO EXPLORATÓRIO PARA A MELHORIA DAS ESTIMATIVAS DAS RECEITAS DO ISSQN PARA O MUNICÍPIO DE IVOTI - PERÍODO 2010 - 2015

RESUMO: O objetivo principal do presente trabalho é a melhoria das estimativas de arrecadação do Imposto sobre Serviços de Qualquer Natureza - ISSQN, para o Município de Ivoti. Para isso, há necessidade de encontrar um modelo, dentre os muitos disponíveis na literatura, mas nem todos aplicáveis aos pequenos municípios sem recursos, como do município em estudo e que demonstre confiabilidade nas projeções que forem geradas. Dessa forma, foi aplicado no estudo o método de indicadores que utiliza parâmetros de preços, quantidade, efeito da legislação e crescimento real da base tributável, pois foi verificado que o mesmo reflete a influência dos cenários econômicos local, regional e nacional. O método foi aplicado para estimar as receitas do período 2010 a 2015, utilizando como base o mês do ano anterior, a média do ano anterior e a média do trimestre que antecede ao mês base. Após, comparou-se os resultados com a arrecadação já realizada e os dados dos orçamentos de cada um dos exercícios. Dessa forma, obtivemos como resultado reestimativas com variações médias entre de 2 a 3\%, quando comparadas com os valores arrecadados, contrapondo com $24 \%$ das diferenças encontradas nas peças orçamentárias. Palavras-chave: Administração pública. Orçamento público. Impostos e tributos. Sistema de arrecadação. 
NOME: MARCELO TRINDADE DA SILVA

TíTULO: AS AÇÕES JUDICIAIS DE NUNCIAÇÃO DE OBRA NOVA E A RESPONSABILIDADE DO GESTOR MUNICIPAL

RESUMO: Trata-se de trabalho voltado a demonstrar o cotidiano do trâmite judicial das ações de nunciação de obra nova, no âmbito municipal, no contexto do município de Garibaldi (RS), onde objetivou-se os dados estatísticos dos últimos cinco anos, para demonstrar que, por vezes, ocorreu omissão por parte dos gestores que administraram o município durante o período. Dada a omissão constatada, foi demonstrado o prejuízo econômico, administrativo e urbanístico para a coletividade, bem como a possível imputação de ato improbo pelos gestores, em especial dado a ausência de uma política voltada ao controle urbanístico, mas em especial por promover a regularização, autorizado por legislação municipal de autoria do gestor atual, de imóveis sem qualquer condição de regularização à luz do Plano Diretor e do Código de Obras.

Palavras-chave: Plano diretor. Políticas públicas. Administração pública. Orçamento público.

NOME: MÁRCIA CRISTINA PAIVA VIEIRA ZINI

TíTULO: O PANORAMA DA SITUAÇÃO SOCIAL DAS CRIANÇAS E ADOLESCENTES EM ACOLHIMENTO INSTITUCIONAL NO MUNICÍPIO DE SÃO FRANCISCO DE PAULA - RS

RESUMO: O objetivo deste trabalho é apresentar o perfil das famílias de crianças e adolescentes em medida protetiva de acolhimento institucional no município de São Francisco de Paula-RS, no período de 2013-2014, devido ao significativo aumento do ingresso no serviço de alta complexidade. Expõe a história da construção do serviço de abrigo no município, apresenta aspectos da estrutura de assistência social, a dificuldade de acesso das famílias na rede de proteção, principais motivos de acolhimento institucional e desejo de reintegração familiar. Essa pesquisa evidenciou que o motivo de maior incidência da aplicação de medida protetiva de abrigo, refere-se direta ou indireta à pobreza. Adotou-se o estudo de caso, identificando as famílias que mantinham contato de maneira mais regular com a criança e ou adolescente, independentemente das configurações familiares apresentadas pelos sujeitos na convivência comum, seja por laços consanguíneos, afetividade, solidariedade ou necessidade. Foram elaboradas sugestões para efetiva implantação do Sistema Único de Assistência Social - SUAS e a consequente redução da aplicação de medita protetiva de acolhimento institucional, ao menos quando identificada situação de risco social.

Palavras-chave: Acolhimento Institucional. Criança. Adolescente. Assistência social. Políticas públicas. 
NOME: MÁRCIO VEDANA

TíTULO: CUMPRIMENTO DAS PRERROGATIVAS DA LEI DE ACESSO À INFORMAÇÃO № 12.527 PELOS MUNICÍPIOS BRASILEIROS

RESUMO: O presente estudo visa a análise dos municípios brasileiros quanto ao atendimento das exigências determinadas pela Lei de Acesso à Informação no 12.527 (LAI). Esta lei, que entrou em vigor em maio de 2012, tem como propósito regulamentar o direito constitucional de acesso dos cidadãos às informações públicas no país e representa uma mudança de paradigma em matéria de transparência pública, pois define que o acesso é a regra e o sigilo a exceção, estimulando a participação e controle social dos cidadãos. A metodologia se baseia na análise dos sítios eletrônicos oficiais do poder executivo dos cinco municípios mais populosos de cada Estado da federação quanto ao atendimento da LAI. Como resultado, constatou-se que nenhum município cumpriu com todos os itens analisados e apenas oito municípios atingiram $75 \%$ de cumprimento sendo que oitenta e sete municípios não atingiram o atendimento da metade dos quesitos, o que representa $66,92 \%$ do total da amostra. Diante disso, fica claro o longo caminho para que os municípios efetivamente se adaptem à LAl, promovendo uma real cultura da transparência e do direito à informação.

Palavras-chave: Lei de acesso à informação. Transparência. Controle Social. Municípios.

\section{NOME: MARCOS FERNANDO BOETTCHER}

TíTULO: O DESAFIO DA SECRETARIA MUNICIPAL DE EDUCAÇÃO DE PORTO ALEGRE NO PROCESSO DE TERCEIRIZAÇÃO DO SERVIÇO PÚBLICO.

RESUMO: O presente trabalho relata o processo de terceirização na administração pública, mais especificamente na Secretaria Municipal de Educação de Porto Alegre (RS). No sentido de aprofundar os estudos sobre a matéria serão apresentas as características gerais da terceirização, a legislação vigente sobre o tema, a terceirização na administração pública e os motivos e fatores que levam o aparelho estatal a usar este modelo de gestão na prestação dos serviços públicos. Por final analisaremos a importância deste processo num órgão público da prefeitura de Porto Alegre, onde será analisada a prestação de serviços junto a este órgão público, a integração entre os funcionários terceirizados e os servidores efetivos assim como será verificada a gestão e fiscalização dos serviços terceirizados e por fim será efetuada uma análise da qualidade do serviço terceirizado. Através deste estudo as informações levantadas serão analisadas e as conclusões poderão trazer subsídios para o aprimoramento na prestação dos serviços terceirizados, tendo como objetivo final, o oferecimento de serviços públicos de forma eficiente e de qualidade à população.

PALAVRAS-CHAVE: Administração pública. Políticas de educação. Relações de trabalho. 
NOME: MARIA DA GRAÇA SOUZA DA SILVA

TÍTULO: O PODER PÚBLICO MUNICIPAL E AS COOPERATIVAS HABITACIONAIS DE PORTO ALEGRE: PARCERIAS PARA A PROMOÇÃO DE HABITAÇÕES DE INTERESSE SOCIAL

RESUMO: Este trabalho tem por objetivo analisar as parcerias firmadas entre o Poder Público Municipal e as cooperativas habitacionais de Porto Alegre (RS), para a promoção de habitações de interesse social. Expõe o contexto histórico de criação das cooperativas habitacionais no Brasil, apresenta os programas habitacionais implementados no Município e analisa o Programa Municipal de Fomento às Cooperativas Habitacionais de Porto Alegre, por meio das ações e obras requeridas pelas entidades cooperativas, ao Departamento Municipal de Habitação (DEMHAB), para as cooperativas de baixa renda. Adotou-se o estudo de caso, identificando as cooperativas, as demandas via Orçamento Participativo (OP), as regiões de origem e de destino dos cooperativados, os recursos investidos, os critérios adotados e objetos contratados, com delimitação no período entre 2004 e 2014, após criação do referido programa e instituição do Fundo Nacional de Habitação de Interesse Social (FNHIS). Demonstrou-se a evolução do cooperativismo, sua relação com o Estado, seus desafios e conquistas para a aquisição da casa própria. Avaliaram-se os avanços e os limites dessas parcerias para a redução do déficit habitacional em Porto Alegre. Palavras-chave: Administração pública. Políticas de habitação. Plano Diretor. Cooperativas habitacionais.

\section{NOME: MARIA DILES CAMPOS POLEZE}

TÍTULO: AVALIAÇÃO DE POLÍTICAS PÚBLICAS DE SANEAMENTO BÁSICO: UM ESTUDO DE CASO NO MUNICÍPIO DE GRAMADO - RS

RESUMO: A avaliação da gestão em políticas públicas voltadas para o saneamento básico é importante, pois desta prestação de serviços depende a saúde e uma melhor qualidade de vida para a população. A falta de saneamento básico está vinculada a várias doenças e também à não preservação do meio ambiente. A fim de pesquisar como a comunidade de Gramado está avaliando a gestão em políticas públicas voltadas para o saneamento básico, foi realizado um estudo de caso com aplicação de um questionário em 500 residências atendidas pela Companhia Riograndense de Saneamento (CORSAN) no município, tendo como objetivo geral avaliar as políticas públicas de saneamento básico (tratamento de água e coleta e tratamento de esgoto) e identificar desafios e oportunidades para aperfeiçoar a gestão e a condução de políticas públicas para o saneamento básico. Os resultados apontam para o entendimento que a população de Gramado (RS) está satisfeita com os serviços prestados pela CORSAN e com a qualidade da água distribuída. Acham justo o preço cobrado pelo tratamento e distribuição de água e muito alto o preço cobrado pela coleta e tratamento de esgoto. Reconhecem o quanto é importante ter saneamento básico para uma melhor qualidade de vida e para o desenvolvimento das cidades e preservação do meio ambiente. Quanto aos investimentos em saneamento básico, concluíram que não estão atendendo às necessidades da população. Concluímos que é necessário ampliar os serviços de coleta e tratamento de esgoto para que sejam atendidas as necessidades da comunidade de Gramado e ampliado o trabalho de divulgação e conscientização da importância do saneamento básico para as pessoas e para o meio ambiente.

Palavras-chave: Administração pública. Políticas públicas. Saneamento básico. Avaliação de políticas públicas. 
NOME: MISAEL LUÍS GIARETTA

TÍTULO: ESTUDO DA DISTRIBUIÇÃO DE RECURSOS NO ORÇAMENTO PÚBLICO MUNICIPAL DE IVOTI

RESUMO: O presente trabalho de conclusão de curso consiste na análise da distribuição de recursos no orçamento público municipal de Ivoti/RS. Como objetivo principal, buscou-se a verificação no período de 2010 a 2014, de que o aumento da despesa pagamento de pessoal pelo executivo municipal é acompanhado pela diminuição nos investimentos com recursos próprios em obras e instalações públicas. No embasamento teórico foram estudadas a evolução e conceitos da administração pública, serviço público, a receita e as despesas no orçamento público, a aplicação do plano de contas no setor público e o gasto com pessoal, caracterizados os agentes, cargos e funções públicos para então, descrever a Lei de Responsabilidade Fiscal em detrimento do gasto com pessoal. Seguindo o estudo, são apresentados o município de Ivoti/RS e a análise de dados de suas receitas e despesas, com o auxílio de tabelas e gráficos. Por fim, diante dos resultados verificados, observa-se no período o aumento da despesa com pessoal e uma diminuição nas despesas com obras e instalações. Palavras-chave: Administração Pública. Lei de Responsabilidade Fiscal. Orçamento público. Auditoria.

$$
\star \star \star
$$

\section{NOME: NAIRO VENÍCIO WESTER LAMB}

TíTULO: ANÁLISE DOS SERVIÇOS PÚBLICOS DE SANEAMENTO BÁSICO NO MUNICÍPIO DE RIO PARDO ENTRE 2010 E 2014

RESUMO: O presente trabalho buscou analisar o serviço de saneamento ambiental no município de Rio Pardo, no período de 2010 a 2015. Optou-se por este tema porque ainda existem poucos trabalhos acadêmicos que abordem a gestão dos serviços públicos de saneamento básico, conforme estabelecido na Lei 11.445/07, a qual estabeleceu a obrigatoriedade dos municípios terem um Plano Municipal de Saneamento Básico. Para tanto, é apresentada a evolução do saneamento no mundo e no Brasil, com destaque para as mudanças nas políticas públicas do setor experimentadas a partir de 2003, com destaque para a instituição da Lei do Saneamento (L.11.445/07) e o Plano Nacional de Saneamento Básico (PLANSAB), instituído em 2013. Após, o Plano Municipal de Saneamento Básico de Rio Pardo, instituído em 2011 e os primeiros anos de sua aplicação em consonância com o contrato de concessão do serviço público, firmado entre o ente municipal e a CORSAN. Destacou-se a constituição do Fundo Municipal de Gestão Compartilhada, instituído com objetivo de garantir a destinação de valores exclusivamente para aplicação no setor ambiental. Apesar de problemas apontados, como a necessidade de aumento da participação popular na tomada de decisões, e de ainda ser cedo para avaliar se o Plano cumprirá sua meta de universalizar o acesso ao saneamento até 2030, ainda assim, conclui-se que houve significativo avanço na gestão dos serviços públicos de saneamento no município de Rio Pardo.

Palavras-chave: Administração pública. Políticas públicas. Saneamento básico. Avaliação de políticas públicas. 
NOME: OSMAR LUIS FREITAG BENCKE

TÍTULO: PROCESSOS DE TRABALHO EM MEIO ÀS POLÍTICAS SOCIAIS: UM ESTUDO DE CASO DO CENTRO DE REFERÊNCIA DA ASSISTÊNCIA SOCIAL DE TRÊS PASSOS

RESUMO: O CRAS é a porta de entrada dos usuários na política de assistência social na busca da superação das necessidades destes até o encontro da emancipação do sujeito e sua família. Neste objetivo, a análise dos processos existentes no CRAS, desde a acolhida aos usuários e seu atendimento inicial até os encaminhamentos finais, proporciona uma nova visão sobre a necessidade de estruturação de processos executados, de forma a proporcionar o atendimento às demandas dos usuários. Assim, esta pesquisa teve como objetivo identificar os processos de trabalho existentes no Centro de Referência da Assistência Social (CRAS) do Município de Três Passos, e como estes podem contribuir para a melhoria dos serviços prestados. Com base nas observações realizadas e na revisão teórica do trabalho, permitiu-se a descrição da estrutura da organização e a fluxogramação dos processos executados no CRAS. Percebeu-se, a partir dos fluxogramas gerados, a necessidade de reestruturação dos procedimentos relacionados à recepção dos usuários e arquivamento de formulários e documentos surgidos nos processos, de forma a melhorar execução dos serviços e possibilitar a satisfação dos usuários dos serviços do CRAS. Palavras-chave: Assistência Social. Administração pública. Políticas públicas. Saneamento básico. Avaliação de políticas públicas.

NOME: PÂMELA SILVEIRA HUGO

TíTULO: A COLABORAÇÃO DO SISTEMA DE REGISTRO DE PREÇOS PARA O PLANEJAMENTO ORGANIZACIONAL DA ADMINISTRAÇÃO PÚBLICA

RESUMO: O Sistema de Registro de Preços é um regime de contratação diferenciado que auxilia no processo de contratação (aquisição) de bens e serviços pela Administração Pública. A pesquisa teve como objetivo geral discorrer sobre o funcionamento e utilização do Sistema de Registro de Preços, em seu primeiro apontamento legal na Lei de Licitações (8.666/93) até a sua atual regulamentação pelo Decreto Federal no 7.892/2013. E como objetivos específicos: demonstrar quais as implicações da utilização desse sistema para a Administração Pública, quais as vantagens e desvantagens desse tipo de contratação, bem como se apontar as possíveis falhas e riscos advindos dessa relação. Constatou-se assim que através deste Sistema é possível registrar preços de produtos/prestação de serviços por período determinado (máximo de 12 meses) e durante este interregno adquirir ou contratar conforme os preços registrados, segundo a necessidade do órgão, furtando-se desta forma de compras parceladas, custo com estocagem e armazenamento e ainda evitando o desperdício de produtos que muitas vezes perecem em locais inapropriados, tornando-se inadequados para o uso. Serão demonstrados ao longo do trabalho os prós e contras do uso dessa nova possibilidade de contratação pelo ente público, bem como explicará as formas e as implicações desta opção trazida pela Lei Federal 8.666/93 e regulamentada pelo Decreto 7.892 de 23 de janeiro de 2013. Em síntese, pelo menos quatro dos grandes princípios basilares da Administração Públicas poderão ser contemplados na utilização do SRP, são eles: Princípio da Legalidade, Princípio da Impessoalidade, Princípio da Economicidade e Princípio da Eficiência, de acordo com o informado no decorrer do tema proposto.

Palavras-chave: Administração pública. Orçamento público. Lei das licitações. 


\section{NOME: RAFAEL PADILHA DEVOS \\ TíTULO: CONFLITO DE COMPETÊNCIA DO ISS ENTRE O MUNICIPIO DE DOMICILIO DO PRESTADOR E O MUNICIPIO DA EXECUÇÃO DO SERVIÇO}

RESUMO: O trabalho apresenta, de forma sistematizada, a estrutura do Sistema Tributário Nacional e as formas de tributos previstas na Constituição Federal/1988, abordando os tributos que são de competência dos Municípios. Apresenta um estudo específico sobre o Imposto Sobre Serviço (ISS) e sua regulamentação pela Lei Complementar nำ16/2003 e o pelo Decreto-lei n 406/1968 com o objetivo de abordar a problemática dos conflitos de competência entre os municípios brasileiros referentes à cobrança do ISS, através da análise do regramento legal sobre a fixação do sujeito ativo da obrigação tributária. Analisa também, a posição jurisprudencial dos Tribunais Brasileiros competentes a conhecerem os conflitos provenientes das aplicações das normas sobre o tema. Explicita um caso conflito envolvendo os municípios de Camaquã/RS e Chuvisca/RS pela cobrança do ISS. Por fim, demonstra a competência do município do estabelecimento do prestador como regra geral para a cobrança do imposto, e o local da execução do serviço como exceção.

Palavras-chave: Gestão Pública Municipal. Administração pública. Orçamento público. Gestão Tributária.

NOME: RÉGIS ALEX MATTIONI

TíTULO: ORÇAMENTO E GESTÃO FISCAL: ANÁLISE DA PARTICIPAÇÃO POPULAR EM AUDIÊNCIAS PÚBLICAS NO MUNICÍPIO DE IJUÍ

RESUMO: A participação popular é uma das expressões do Estado Democrático de Direito. Todos os cidadãos têm o direito de participar livremente da construção dos valores da sociedade. A Audiência Pública é um dos instrumentos garantidos constitucionalmente para a efetivação da participação popular e, no Processo Legislativo, se configura em uma importante etapa, principalmente no tocante a matérias relacionadas ao orçamento público. Considerando a relevância da participação popular no Processo Legislativo, este estudo evidencia dados sobre esta participação nas Audiências Públicas da Câmara de Vereadores de ljuí, entre os anos de 2011 e 2014. A análise destes dados é enriquecida com entrevistas realizadas com Parlamentares e cidadãos que já tenham participado destas audiências, objetivando compreender os motivos dos baixos índices de participação e identificando melhorias que possam ser implementadas, no intuito de promover um maior interesse dos cidadãos em exercer deu papel na democracia.

Palavras-chave: Administração pública. Orçamento público. Participação popular. Processo legislativo. 
NOME: RITA DE CÁSSIA DA SILVA BECCO

TíTULO: A DEMOCRATIZAÇÃO DA COMUNICAÇÃO SOCIAL NO BRASIL E A GESTÃO DA COMUNICAÇÃO PÚBLICA NO MUNICÍPIO DE PORTO ALEGRE

RESUMO: O trabalho apresenta uma análise da relação entre as questões de democratização da comunicação social no Brasil e a gestão da comunicação pública municipal, tendo como referência o gerenciamento da comunicação no município de Porto Alegre. Dentre os objetivos estão: identificar e analisar a contribuição da gestão da comunicação pública local no processo de democratização da comunicação social. Para tanto, contextualiza conflitos e conceitos em torno dos temas e descreve o exercício da comunicação pública na esfera local, tendo como enfoque a atividade de publicidade. Além disso, descreve estrutura, estratégias e orçamento do Gabinete de Comunicação Social da Prefeitura de Porto Alegre, analisa suas despesas em publicidade e aponta possibilidades de melhorias relacionando-as com o processo de democratização da comunicação social. Após análise dos dados disponíveis, conclui-se que os temas são complementares e apresentam pontos de convergência e interdependência, cuja compreensão pode levar a alternativas para construção de consensos em uma agenda pública pautada por conflitos. Palavras-chave: Administração pública. Comunicação social. Cidadania. Políticas públicas. Políticas de comunicação.

NOME: RITA FREZZA MAGANINI

TíTULO: FATORES DE SAÚDE, ADOECIMENTO E ABSENTEÍSMO: UMA ANÁLISE NO AMBIENTE PRISIONAL DE SÃO FRANCISCO DE PAULA

RESUMO: Realizou-se este estudo de caso numa instituição prisional, na cidade de São Francisco de Paula, interior do Estado do Rio Grande do Sul, a partir da investigação das condições de trabalho no sistema prisional, que contribuem para processos de saúde, adoecimento e absenteísmo entre os servidores, e que interferem na gestão de recursos humanos. A pesquisa contou com o levantamento de dados, referentes ao absenteísmo e afastamentos nesta casa prisional, no período entre dezembro de 2010 e dezembro de 2014, identificação de estudos prévios indicando as características e dificuldades na gestão dos recursos humanos no ambiente prisional, e os principais fatores de saúde e adoecimento de servidores neste contexto, comparando-se os dados coletados com a descrição na literatura. A principal causa de absenteísmo entre os servidores penitenciários parte do adoecimento psíquico. Os dados também sugerem recorrência e grande frequência de absenteísmo entre os servidores, o que também já foi relatado em estudos prévios. Das condições mencionadas como fatores de adoecimento, identificou-se a convivência em longas jornadas com situações de encarceramento, violência e exclusão; a prisionização; a pressão social para a realização de justiça versus o papel de agentes ressocializadores; o temor da represália extramuros; e, por fim, o sentimento de desvalorização profissional. Dos fatores protetivos e associados à saúde dos servidores estão as políticas de valorização profissional; o apoio percebido entre os colegas e a autonomia dada por superiores; a adoção de hábitos de vida mais saudáveis e a constante capacitação.

Palavras-chave: Administração pública. Políticas de saúde. Sistema prisional. Recusos humanos em saúde. 
NOME: ROGÉRIO CARLOS RIBAS BITTENCOURT

TíTULO: A IMPORTÂNCIA NA MELHORIA DA SINALIZAÇÃO INDICATIVA TURISTICA PARA O MUNICIPIO DE NOVO HAMBURGO

RESUMO: O avanço do turismo no Brasil contribui para a adequação dos municípios em receber visitantes que ao saírem de seus locais de residência, buscam além dos atrativos turísticos, serviços e equipamentos, uma boa estrutura, que lhes cause comodidagem e segurança. Este estudo analisa a sinalização indicativa e turística de Novo Hamburgo (RS), com a intenção de contribuir para a melhoria no turismo da cidade. A metodologia empregada utilizou-se da revisão bibliográfica como procedimento técnico. O estudo de campo se deu em três momentos distintos, no primeiro momento foi realizado o diagnóstico da atual sinalização das entradas da cidade via BR 116, RS 239 e atrativos existentes no município. O segundo momento compreendeu a aplicação de questionários de perguntas fechadas e abertas para turistas, moradores da cidade e profissionais do trânsito. No terceiro e último momento foi aplicado questionário do tipo semiestruturado, combinando perguntas abertas e fechadas, para secretário de turismo do município. Esta pesquisa apontou a necessidade de melhorar a sinalização turística da cidade, como premissa para o desenvolvimento turístico do município estudado, desta forma atendendo o anseio dos turistas, bem como dos moradores. Os dados coletados apontam para a necessidade de rever a sinalização turística de Novo Hamburgo como premissa a cidade desenvolver-se turisticamente.

Palavras-chave: Administração pública. Turismo. Propaganda e marketing.

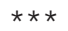

NOME: RÔMULO NASCIMENTO BARROS

TíTULO: A EFICÁCIA DAS DECISÕES DOS PROCESSOS DE CONTAS: SANTO ANTÔNIO DAS MISSÕES/RS

RESUMO: Este estudo visa descobrir a eficácia das decisões dos processos de contas de gestão do Tribunal de Contas do Rio Grande do Sul nos exercícios de gestão do executivo municipal compreendidos entre o período dos anos de 2010, 2011, 2012 e 2013 na localidade de Santo Antônio das Missões/RS. Para isso, se realizou um estudo das normas constitucionais e infraconstitucionais sobre o Controle Externo dos Tribunais de Contas. A metodologia utilizada foi a pesquisa empírica e o método do estudo de caso, realizando-se pesquisa em bibliografias, jurisprudências, com explicações embasadas em trabalhos publicados, como livros, revistas, artigos, dissertações, teses, enfim, publicações especializadas, imprensa escrita, dados oficiais publicados na Internet e análise documental das decisões dos processos de contas. Para tanto, foram utilizadas decisões que denotam a aprovação (ou não) de contas, e através disto descobrir se as decisões dos processos de contas possuem eficácia. Após a análise das decisões dos processos de contas de gestão municipal, verificou-se muitas inconformidades reincidentes que comprovam o descumprimento das decisões, configurando a falta de eficácia, resultando prejuízos ao erário público.

Palavras-chave: Tribunal de Contas. Orçamento público. Políticas públicas. Avaliação de políticas públicas. Auditoria. 
NOME: ROQUE DE BASTOS FEIJÓ

TíTULO: A (I)LEGITIMIDADE NA REALIZAÇÃO DOS SERVIÇOS NÃO EMERGENCIAIS PELO CORPO DE BOMBEIROS MUNICIPAL DE SÃO FRANCISCO DE PAULA - RS

RESUMO: O presente trabalho consiste em um estudo de caso com o objetivo de investigar o custo na realização dos serviços não emergenciais, no ano de 2014, pelo Corpo de Bombeiros Municipal de São Francisco de Paula (RS). Apresenta-se um enfoque das atribuições dos Corpos de Bombeiros de um modo geral, em especial do Corpo de Bombeiros Municipal de São Francisco de Paula - RS. Apresentam-se, também, breves conceitos dos serviços não emergenciais. Os dados levantados tornam perceptíveis que estes serviços não emergenciais estão, de certa forma, impregnados no dia a dia dos bombeiros de um jeito que se confundem com as atribuições dos mesmos, pois são realizados desde a criação do Órgão. Os resultados do estudo demonstram um custo elevado na realização dos serviços não emergenciais, assim como, que estes serviços podem ser realizados por outras secretarias ou órgãos municipais. Também se conclui que o gestor municipal pode oficializar esta escolha que se deu através dos bombeiros, incluindo-a oficialmente nas atribuições dos mesmos. Por outro, lado fica evidente que o custo gerado pelos referidos serviços compromete parcela relevante do orçamento dos bombeiros; recursos que poderiam ser investidos na própria corporação. Palavras-chave: Administração pública. Corpo de bombeiros. Defesa civil.

NOME: ROSANE BOELTER SCUR

TÍTULO: GESTÃO TRIBUTÁRIA MUNICIPAL: UM ESTUDO DE CASO DO SISTEMA DE ARRECADAÇÃO DO IMPOSTO PREDIAL E TERRITORIAL URBANO (IPTU) DA PREFEITURA MUNICIPAL DE CANELA.

RESUMO: Frente à necessidade de uma gestão pública eficiente, seja na aplicação de recursos, ou na arrecadação destes, este trabalho analisa a eficiência da gestão tributária da Prefeitura Municipal de Canela. Dado o cenário econômico desfavorável a nível nacional, a arrecadação tributária municipal tem sido alvo de atenção, visto que as políticas públicas implicam ações importantes também na gestão da arrecadação. O trabalho tem por objetivo propor melhorias na administração tributária do Município de Canela (RS), buscando a eficiência na gestão tributária municipal. Uma série histórica da arrecadação do IPTU e da dívida ativa foi apurada, dos exercícios de 2010 a 2014. Foi possível verificar que a arrecadação do IPTU tem a cada exercício financeiro menor percentual de participação na arrecadação total. No desenvolvimento do trabalho, foi realizado um cruzamento de informações, com os dados de imóveis inscritos no cadastro imobiliário e dados das guias do Imposto sobre a Transmissão de Bens Inter Vivos (ITBI). Foi possível evidenciar discrepâncias entre os valores venais de imóveis com os valores praticados pelo mercado imobiliário. A revisão da planta de valores deve ser desenvolvida com brevidade. Pelas amostras, foi possível verificar a defasagem dos valores venais. A atualização dos preços de referência poderá incrementar significativamente a arrecadação do IPTU. Finalizando, a proposta sugerida para a administração do Município é o investimento na atualização do cadastro imobiliário e revisão da planta de valores, proporcionando assim uma melhora na arrecadação do IPTU, bem como tornar mais eficiente a gestão tributária.

Palavras-chave: Gestão tributária. IPTU. Orçamento público. Administração pública. Plano diretor. 
NOME: ROSÂNGELA FILEMON FERREIRA DA SILVA

TíTULO: SISTEMA ADMINISTRATIVO FINANCEIRO DE GESTÃO PÚBLICA: UM ESTUDO DE CASO NA TESOURARIA DO MUNICÍPIO DE NOVO HAMBURGO

RESUMO: Este estudo de caso na Tesouraria do Município de Novo Hamburgo tenta demonstrar de que forma é possível identificar a eficiência do Sistema Administrativo Financeiro de Gestão Pública na Tesouraria da Prefeitura de Novo Hamburgo. A Lei de Responsabilidade Fiscal possui requisitos básicos de controle e transparência da Gestão Pública. Sendo que, para se ter transparência, faz-se necessária a eficiência com a utilização de métodos, rotinas e procedimentos adequados. 0 objetivo da análise é verificar o sistema administrativo financeiro informatizado e integrado na Tesouraria do município de Novo Hamburgo, buscando identificar seu atendimento às necessidades de Gestão Pública. Como objetivos específicos, são analisados o funcionamento e as contribuições desse sistema dentro da Tesouraria na Gestão Pública de Novo Hamburgo. Para que os resultados possam ser estudados são apresentadas a abordagem conceitual da eficiência e a importância dos sistemas operacionais na Gestão Pública. A pesquisa realizada é classificada quanto aos seguintes aspectos: qualitativa pela abordagem do problema, exploratória de acordo com os objetivos e estudo de caso com base nos procedimentos técnicos utilizados. A transparência é uma das características do princípio da eficiência. Conclui-se, com isso, falta de eficiência nos métodos, procedimentos e rotinas na Tesouraria do Município de Novo Hamburgo.

Palavras-chave: Gestão Pública. Lei de Responsabilidade Fiscal. Orçamento público. Administração pública municipal.

\section{NOME: ROSANI ZACHOW}

TÍTULO: EFETIVAÇÃO DA VIGILÂNCIA EM SAÚDE: HÁ FALTA DE RECURSOS?

RESUMO: O estudo foi realizado a partir da análise da utilização dos recursos do Piso Fixo de Vigilância em Saúde; nos municípios de Cruz Alta, ljuí e Palmeira as Missões que, respectivamente, são sede da 9ª $15^{a}$ e 17a Regional de Saúde do Estado do Rio Grande do Sul no período de 2011 a 2013. Assim nosso problema de pesquisa consiste em responde a seguinte questão: o que dificulta a efetivação da Vigilância em Saúde no SUS é a falta de recursos? Para dar conta de responder a nossa questão temos como objetivo principal: analisar a disponibilidade de recursos financeiros do Piso Fixo de Vigilância em Saúde nos municípios de Cruz Alta, ljuí e Palmeira das Missões 9ª $15^{a}$ e 17a Coordenadoria de Saúde do Estado do Rio Grande do Sul, no período de 2011 a 2013. Como objetivos específicos: 1) Avaliar a utilização dos recursos do Piso Fixo de Vigilância em Saúde nos municípios de Cruz Alta, ljuí e Palmeira das Missões; 2) Identificar semelhanças e diferenças na utilização do Piso Fixo de Vigilância em Saúde. A presente pesquisa foi desenvolvida por meio de uma abordagem comparativa e, como método, utilizou-se o estudo de caso no qual o fenômeno será analisado dentro de seu contexto. Pelos dados apresentados a resposta para efetivação da Vigilância em Saúde nos municípios estudados passa pela gestão, ou melhor, pela falta de critérios na utilização dos recursos financeiros, pois na fonte de recurso analisada a desculpa de falta de recursos passa longe pelos saldos crescentes nas contas.

Palavras-chave: Vigilância em saúde. Administração pública. Orçamento público. Políticas de saúde. Sistema Único de Saúde. 
NOME: SANDRA REGINA MACHADO ECOTEM

TíTULO: VIOLÊNCIA ESCOLAR: UMA ANÁLISE DAS OCORRÊNCIAS NAS ESCOLAS DE ENSINO FUNDAMENTAL NO MUNICÍPIO DE CAXIAS DO SUL-RS

RESUMO: A violência escolar é um tema discutido diariamente nos meios de comunicação. Esse fenômeno acontece no ambiente interno e externo da escola e vem causando preocupações para as autoridades, pais, professores, alunos e direção. Diante deste cenário, o município de Caxias do Sul vem investindo em projetos e programas para combater a violência nas escolas de ensino fundamental. Este trabalho, realizado através de pesquisa qualitativa, com coleta de dados por meio de pesquisa documental e de entrevistas, levantou dados sobre os índices de violência suas causas e consequências nas escolas municipais de ensino fundamental no município de Caxias do Sul no período de 2009 a 2013, os principais tipos de violências, a faixa etária, sexo, turno, dia da semana, e as ocorrências por eixos e por regiões administrativas. Foram avaliados os pontos positivos e negativos, na percepção dos entrevistados e ainda sugestões de melhorias. Percebe-se que há necessidade de investimentos que foque direto no problema para que o mesmo não tome proporções que possa gerar um dano maior na criança e no adolescente, como traumas psicológicos e emocionais. Palavras-chave: Ensino fundamental. Políticas de educação. Administração pública. Violência.

NOME: SANDRO PEDRO RIZZI DRI

TÍTULO: CONTROLE INTERNO: UMA IMPORTANTE FERRAMENTA NA GESTÃO PÚBLICA DE NOVA HARTZ

RESUMO: A gestão pública municipal passa por grandes transformações nos últimos anos, principalmente na forma de gerir o negócio público, pois requer mais controle e transparência nas ações do gestor público. A Constituição Federal de 1988 instituiu a obrigatoriedade do Controle Interno nos entes da federação, e a Lei Complementar no 101/2000, a Lei de Responsabilidade Fiscal, regulamentou a necessidade desses controles. Este trabalho teve como objetivo verificar se o Controle Interno pode ser uma ferramenta eficiente na prevenção e correção de ações irregulares para o gestor público de Nova Hartz. Para alcançar este objetivo, primeiramente procedeu-se com uma pesquisa bibliográfica sobre o assunto. Na sequência, buscou-se descrever os instrumentos utilizados e a rotina de atuação do Controle Interno no município, e relacionar essa atuação com o determinado pela legislação. Também foi aplicado um questionário, entre os secretários municipais e diretores de cada secretaria, com o objetivo de obter a opinião e o nível de conhecimento desses agentes públicos, referente ao Controle Interno do município. Após a aplicação do questionário, as respostas foram colocadas em um quadro para facilitar a análise dos dados. A análise permitiu concluir que o Controle Interno de Nova Hartz está estruturado em conformidade com o determinado pela legislação, e pelas respostas do questionário, percebeu-se que a maioria está comprometida com a importância do Controle Interno para a administração pública municipal. Palavras-chave: Administração pública. Orçamento público. Auditoria. 
NOME: SHAIANE CAROLINE KOCHHANN

TÍTULO: PROJETOS IMPLANTADOS VERSUS IMPACTO ECONOMICO SOBRE A ECONOMIA LOCAL DE PALMEIRA DAS MISSÕES-RS

RESUMO: O governo, por meio da necessidade comum da população, busca através da aplicação de ações estruturalistas, desenvolver e melhorar o padrão e as condições de vida de um determinado grupo. Então, determina-se o tempo de vida destas ações, até que se alcance o objetivo satisfatório e que venha suprir a necessidade pela qual ela foi elaborada. Essas ações são denominadas de "políticas públicas". Assim, o objetivo deste trabalho se caracteriza por levantar as políticas públicas aplicadas na área da Indústria e do Comércio Local de Palmeira das Missões-RS e buscar analisar o impacto causado por tais ações. O método, contemplou uma pesquisa qualitativa, apoiada por meio de um estudo bibliográfico a respeito do assunto, bem como por meio da coleta de dados de forma documental, levantada por meio da prefeitura municipal. Como resultado, foi possível observar que há políticas públicas de grande envolvimento por parte da população, entretanto, mesmo que auxilie no desenvolvimento econômico municipal, não é possível inferir que tais medidas venham realmente auxiliar o desenvolvimento econômico em razão das condições estruturais que emergem o ambiente local. Palavras-chave: Administração pública. Orçamento público. Economia local. Desenvolvimento econômico.

NOME: SINESIO GEROMIR KLAUCK

TÍTULO: INCENTIVOS EM ÓLEO DIESEL: POLÍTICA DE FOMENTO AO DESENVOLVIMENTO RURAL EM MORRO REUTER/RS

RESUMO: O presente trabalho tem como objetivo analisar qualitativamente a influência da política de incentivos em óleo diesel para o desenvolvimento rural de Morro Reuter, no período de 2011 a 2014. A pesquisa se remete a um estudo de caso, realizado por meio de entrevistas semiestruturadas junto a nove agricultores, que também são representantes de suas comunidades no Conselho Municipal de Desenvolvimento Agropecuário, bem como com os gestores envolvidos na área da agricultura familiar, no setor público e ambiente institucional. Com o uso da pesquisa documental, foram levantados dados e informações dos produtores rurais, como tamanho das propriedades e tipos de produção predominantes. Também foram analisadas as condições de habilitação no programa, formas de utilização do óleo diesel, demandas, desafios atuais e os avanços obtidos com o programa no período pesquisado. As contextualizações dos temas desse trabalho se remetem à caracterização da agricultura familiar em nível local e mundial, ao processo da industrialização difusa e do surgimento da agricultura de tempo parcial, à pluriatividade e à alocação de políticas públicas. Os resultados apontam a predominância de minifúndios na estrutura fundiária, da silvicultura no modo de produção das propriedades rurais do município e a necessidade de atendimento de critérios para a inserção e continuidade do programa, face ao aumento da demanda pelos incentivos em óleo diesel. Também são vistas a necessidade de existir assistência técnica e representatividade para com os agricultores, devido às transformações da era contemporânea, e o crescimento gradativo de investimentos por parte do setor público, visando alavancar o desenvolvimento rural em Morro Reuter/RS. Palavras-chave: Administração pública. Desenvolvimento econômico. Agricultura familiar. Desenvolvimento rural. 
NOME: TATIANE ALMEIDA DA ROSA

TÍTULO: O PROGRAMA BOLSA FAMÍLIA NO MUNICÍPIO DE CANOAS

RESUMO: O presente trabalho avalia através de uma forma abrangente a gestão do Programa Bolsa Família dentro da Assistência Social no município de Canoas (RS), e tem por objetivo aperfeiçoar o número de beneficiados no Programa Bolsa Família. Para identificar tais fatores foi realizada uma análise dos dados qualitativos, onde foram identificados número de beneficiários, perfil e localização dentro do município, e ainda foram realizadas três entrevistas com os gestores do Programa Bolsa Família. O método utilizado para coletar os dados foi através da pesquisa qualitativa delineada em estudo de caso, onde após a coleta de dados, foi feito um comparativo através de gráficos e tabelas e pela transcrição das entrevistas gravadas, realizou-se uma análise de conteúdo destas entrevistas. Através da análise dos dados, pode-se definir o perfil e o estilo de gestão utilizada na construção do processo de Gestão do Programa Bolsa Família dentro do município de Canoas.

Palavras-chave: Bolsa Família. Programas de transferência de renda. Assistência social. Administração pública.

NOME: TIAGO RODRIGO LUTZER TIZOTTE

TÍTULO: MUDANÇAS INSTITUCIONAIS NO ÂMBITO DAS FINANÇAS PÚBLICAS: O MUNICÍPIO DE AJURICABA/RS

RESUMO: Ao mesmo tempo em que a Constituição Federal de 1988, deu o ponta-pé inicial para a implementação de importantes conquistas políticas e sociais com a regulação, o controle e a transparência das ações de governo, principalmente quando envolvem a aplicação de recursos públicos, conferiu aos municípios autonomia político-administrativa e orçamentária, garantindo a sustentabilidade financeira e política. O objetivo deste trabalho é analisar o comportamento das receitas e dos gastos públicos do município de Ajuricaba/ RS no período de 2002 a 2014, à luz destas mudanças institucionais ocorridas no âmbito das finanças públicas municipais ocorridas a partir da Constituição Federal de 1988. Insere-se além da CF/1988, a Lei de Responsabilidade Fiscal (2000) e a Lei de Acesso a Informação (2011). Analisa-se também se as diferentes visões teóricas sobre a tendência de crescimento dos gastos públicos e a demonstração da ocorrência ou não destas tendências no município de Ajuricaba/RS. Almejando desvendar o comportamento dos diferentes elementos do orçamento com a finalidade de compreender a evolução das receitas e principalmente das despesas da administração municipal.

Palavras-chave: Lei de Responsabilidade Fiscal. Administração pública. Orçamento público. 
NOME: VALDIONOR DADA DOS SANTOS

TÍTULO: A GESTÃO DO SISTEMA ÚNICO DE ASSISTÊNCIA SOCIAL NO MUNICÍPIO DE TRAMANDAÍ - RS ATRAVÉS DA ANÁLISE DOS SERVIÇOS DE PROTEÇÃO SOCIAL

RESUMO: O presente trabalho consiste num estudo para verificar se a gestão do Sistema Único de Assistência Social (SUAS) em Tramandaí (RS) está sendo executada de acordo com as normas e demais legislações instituídas pelo Ministério do Desenvolvimento Social e Combate à Fome. Foram descritas a composição das equipes de referência dos órgãos de Proteção Social, as ações desenvolvidas no município em cada nível de Proteção Socioassistencial e a estrutura física destes órgãos de Proteção. Para materializar os resultados foi realizada pesquisa bibliográfica e documental, e a aplicação de questionário com a coordenação, e quando na ausência desta, com os profissionais técnicos dos órgãos de Proteção Socioassistencial pertencentes à Secretaria de Desenvolvimento e Assistência Social do município. Os principais resultados encontrados foram: ausência de alguns profissionais fundamentais para compor as equipes de referência, assim como a indevida ocupação de cargos comissionados (CC's) em alguns cargos que deveriam ser de profissionais efetivos; a tentativa dos profissionais em realizar as ações de acordo com as normas federais, porém esbarrando na falta de estrutura do município, como por exemplo, a não disponibilização de veículos para a realização de visitas e demais ações, e falta de estrutura da rede socioassistencial para encaminhamento dos usuários e famílias atendidas; e, quanto à estrutura física, que os órgãos existentes estão se adequando as normas, com poucas pendências a serem corrigidas para que se tenha uma estrutura em condições de ofertar um bom trabalho.

Palavras-Chave: Administração pública. Orçamento público. Políticas públicas. Assistência social.

\section{NOME: VANDERLEI ÂNGELO DA LUZ \\ TíTULO: UM DIAGNÓSTICO INICIAL DA REDE DE ATENÇÃO À CRIANÇA E AO ADOLESCEN- TE DE CAXIAS DO SUL - RECRIA}

RESUMO: O objetivo deste trabalho foi o de iniciar um diagnóstico da Rede de Atenção à Criança e ao Adolescente de Caxias do Sul (RECRIA)/RS, a partir da sua história e descrever o atual estágio de seu desenvolvimento. Considerando a importância de criar novas ferramentas para enfrentar as desigualdades sociais, este trabalho apresenta o modelo organizativo em rede, como ferramenta de instituições públicas e privadas, que parte da busca coletiva de objetivos comuns. Buscou-se uma configuração conceitual desta estrutura na literatura de gestão pública com foco em gestão de políticas públicas e redes. Para tanto, se utilizou a metodologia de pesquisa documental/bibliográfica e entrevistas com os sujeitos envolvidos diretamente nas ações realizadas, a fim de mapear a caracterização das entidades participantes e das atividades desenvolvidas. Apresenta-se esta articulação em rede como uma tecnologia à disposição das entidades, comunidades e gestores públicos para uma intervenção social qualificada, que possibilitou resultados concretos na redução da desigualdade social local, qualificando atores e reduzindo o número de crianças e adolescentes em situação de rua. Este é um primeiro estudo aproximativo da organização RECRIA e abre espaço para estudos futuros.

Palavras-chave: Redes sociais. Criança. Adolescente. Administração pública. Assistência social. 
NOME: VANDERLEI RODRIGUES SCHNEIDER

TíTULO: A IMPORTÂNCIA DA APURAÇÃO DE CUSTOS NA ADMINISTRAÇÃO PÚBLICA MUNICIPAL

RESUMO: A contabilidade pública no Brasil vem sofrendo várias alterações nos últimos anos com o objetivo de aprimorar o controle do patrimônio e proporcionar eficiência e eficácia, além de dar mais transparência à utilização dos recursos públicos. Nesse sentido, como o tema controle de custos é exigência da legislação e também da sociedade, o presente estudo teve por objetivo saber se a apuração de custos na administração pública municipal auxilia a fornecer informações gerenciais, como subsídio para a tomada de decisões na área governamental, com o propósito de aprimorar a gestão dos recursos públicos. Portanto, o estudo desenvolveu-se por meio de pesquisa bibliográfica e documental, com base na análise da legislação e com a utilização de exemplos do Município de Bento Gonçalves/RS, para melhor elucidar o tema. As áreas focadas foram Saúde e Educação. Os resultados obtidos mostram uma grande dificuldade em tornar efetiva essa obrigação, pois pouco se tem de concreto na área e há uma diversidade de opiniões de pesquisadores e autores sobre qual a melhor metodologia para apurar os custos do serviço público, já que também, não há impedimento por parte da legislação em se utilizar qualquer dos métodos de custeio. A tendência é a utilização ou do método de custeio direto ou do ABC (Custeio Baseado por Atividade), ou ainda, a melhor alternativa, a combinação dos dois. Porém, essa utilização deve estar estruturada de acordo com as especificidades e particularidades de cada ente público.

Palavras-chave: Administração pública. Orçamento público. Custeio Baseado por Atividade. Auditoria.

NOME: VANDERLEI SONDA BIONDO

TíTULO: IMPLANTAÇÃO DE SISTEMA DE INFORMAÇÃO DE CUSTOS NA ADMINISTRAÇÃO PÚBLICA MUNICIPAL: ESTUDO DE CASO DA PREFEITURA DE HORIZONTINA

RESUMO: Nos últimos anos a administração pública vem enfrentando vários desafios que a obrigam a esforços contínuos de adaptação a novas metodologias, capazes de responder às constantes exigências da sociedade e dos mercados. Devido à obrigatoriedade do Sistema de Informações de Custos do Setor Público - SICSP, este estudo buscou compilar o referencial teórico-legal e prático sobre o tema, visando contribuir para a implantação de um sistema de informação de custos no município de Horizontina (RS). O presente estudo teve como problema/questão de pesquisa: de que forma a gestão de custos, nos termos da Resolução CFC no 1366, que aprova a NBCT 16.11, pode contribuir com a administração pública de Horizontina na busca da melhor prestação de serviços à comunidade? Foi utilizada uma pesquisa bibliográfica realizada em fontes como as leis brasileiras relacionadas com o tema, livros de contabilidade tributária e referências teóricas; também livros de contabilidade tributária e outras referências publicadas sobre o assunto, com o intuito de sanar a problemática do tema e alcançar os objetivos do estudo. Mais provável que será utilizado o método de custeio direto nos diversos centros de custos do ente municipal.

Palavras-chave: Sistema de Informações. Administração pública. Orçamento público. Centro de custos. 
NOME: VERÔNICA DE JESUS OLIVEIRA PACHECO SIGNORI

TÍTULO: TRANSPARÊNCIA NA GESTÃO PÚBLICA DO MUNICÍPIO DE CANOAS: UM ESTUDO NA AÇÃO "FORTALECIMENTO DO PROGRAMA CANOAS ÉTICA"

RESUMO: O princípio da transparência na gestão pública deve ser aplicado, comunicado, compreendido e utilizado. No município de Canoas, no estado do Rio Grande do Sul (RS), o governo municipal aderiu ao Programa Brasil Mais Transparente do Governo Federal e confeccionou um Plano de Metas para o quadriênio [2013-2016]. Dentre as ações relacionadas com a transparência, ressalta-se a ação 50 (Fortalecimento do Programa Canoas Ética). Das diversas metas associadas a esta ação, aquela que melhor corresponde às determinações do termo de adesão do município ao programa é a meta 50.3, na qual estão contidas as premissas para execução, elaboração e realização necessárias à implantação da transparência. O objetivo deste trabalho é relatar a implantação da meta ao longo dos seus cinco semestres de existência, incluindo seu planejamento, execução e avaliação. Esta tem como objetivo gerar visibilidade positiva do trabalho realizado e do atingimento dos requisitos para obtenção do selo de Boas Práticas de Transparência na Internet, certificado pelo Tribunal de Contas do Estado. Para tanto, foi realizado um estudo de caso aprofundado na Controladoria Geral do Município, com o emprego de técnicas de entrevistas, análise de documentos e observação participante. Os principais resultados encontrados sugerem que o planejamento foi eficaz, mas a execução ocorreu de forma parcial e o monitoramento implicou em repactuações das ações em todos os semestres até o presente. Concluiu-se que a ação de fortalecimento do programa, sob a meta da transparência, foi plenamente atingida.

Palavras-chave: Administração pública. Orçamento público. Auditoria. Políticas de comunicação. Cidadania.

NOME: VICENTE ALENIR DA SILVA

TÍTULO: ANÁLISE DOS INDICADORES SOCIAIS DE SÃO FRANCISCO DE PAULA - RS, COMO BASE INFORMACIONAL PARA FORMULAÇÃO DE POLÍTICAS PÚBLICAS

RESUMO: Cada vez mais, o Estado brasileiro precisa atuar de forma eficaz e rápida para atacar os problemas que afligem a sociedade atual. Os indicadores sociais são utilizados para subsidiar as atividades de planejamento público e políticas sociais nas diferentes esferas de governo. No presente trabalho, o objetivo foi analisar os indicadores sociais do município de São Francisco de Paula (RS) diretamente relacionados às pessoas que se encontram em vulnerabilidade social. Para tanto, foram analisados diversos indicadores, como: percentual de pessoas extremamente pobres, percentual de pobres, percentual de pessoas vulneráveis à pobreza, percentual de analfabetos, percentual de pessoas de 18 anos ou mais sem o ensino fundamental completo e em ocupação informal, percentual de crianças de 0 a 5 anos que estão fora da escola, entre outros. Todos resultados foram comparados aos dos municípios integrantes da Região das Hortênsias, à média nacional e, em alguns casos, à média estadual, como forma de ter parâmetros de comparabilidade entre localidades próximas. Verificou-se que a cada censo demográfico, de 1991 para 2000 e de 2000 para 2010, ocorreram melhoras em todas as localidades; na Região das Hortênsias, o município de São Francisco de Paula apresenta os piores resultados. Foi elencado um levantamento das ações, programas e políticas sociais que estão em andamento, com o intuito de mostrar que não estão dando conta de diminuir ineficiências a patamares considerados aceitáveis para o desenvolvimento humano.

Palavras-chave Administração pública. Orçamento público. Indicadores sociais. Planejamento de políticas públicas. 
NOME: VIVIANE BROCHETTO

TíTULO: PERDAS DE ÁGUA E GERENCIAMENTO DE SISTEMAS DE ABASTECIMENTO: UM ESTUDO DE CASO NO MUNICÍPIO DE CAXIAS DO SUL

RESUMO: A crise hídrica que atinge diversas regiões do país chamou a atenção para o grande desperdício de água que ocorre de forma crônica no Brasil. Assim, passou-se a discutir temas como planejamento e gerenciamento da parcela que se esvai antes de chegar ao seu destinatário final. Os métodos utilizados para o desenvolvimento deste trabalho foram as pesquisas bibliográficas e documentais, especialmente nos diagnósticos anuais publicados pelo Sistema Nacional de Informações sobre Saneamento, por ser o maior banco de dados de informações sobre o setor de saneamento do país. Foi realizado um estudo de caso no Serviço Autônomo Municipal de Água e Esgoto de Caxias do Sul (RS), com o objetivo de descrever os reflexos das principais causas e consequências das perdas de água no gerenciamento de um sistema de abastecimento e identificar ações desenvolvidas na Autarquia para solucionar este problema. Houve, ainda, a seleção dos prestadores de serviço público de saneamento do estado do Rio Grande do Sul (RS), constituídos sob a natureza jurídica de Autarquia, para o levantamento dos índices de perdas de faturamento e ocorridos na distribuição. Os principais resultados sinalizam para a complexidade existente no gerenciamento dos sistemas de abastecimento, a necessidade de geração de informações confiáveis, objetivando a fidedignidade dos índices calculados com os volumes apurados, e a verificação da situação estagnada em patamares elevados dos índices observados.

Palavras-chave: Administração pública. Orçamento público. Políticas de saúde. Saneamento básico. Abastecimento de água. 



Impressão:

Evangraf

Rua Waldomiro Schapke, 77 - POA/RS

Fone: (51) 3336.2466 - (51) 3336.0422

E-mail: evangraf.adm@terra.com.br 